UNIVERSIDADE DE SÃO PAULO

FACULDADE DE EDUCAÇÃO

\title{
Implementação de Políticas Públicas: um estudo de caso sobre a ampliação do ensino fundamental para nove anos no município de São Bernardo do Campo
}

\section{Lara Gonzalez Gil}

Dissertação apresentada à Faculdade de Educação da Universidade de São Paulo como requisito parcial para a obtenção do título de Mestra em Educação.

Área de Concentração: Estado, Sociedade e Educação

Orientadora: Profa. Dra. Lisete Regina Gomes Arelaro

São Paulo

2012 
AUTORIZO A REPRODUÇÃO E DIVULGAÇÃO TOTAL OU PARCIAL DESTE TRABALHO, POR QUALQUER MEIO CONVENCIONAL OU ELETRÔNICO, PARA FINS DE ESTUDO E PESQUISA, DESDE QUE CITADA A FONTE.

Catalogação na Publicação

Serviço de Biblioteca e Documentação

Faculdade de Educação da Universidade de São Paulo

372(81.61) Gil, Lara Gonzalez

G463i Implementação de Políticas Públicas: um estudo de caso sobre

a ampliação do ensino fundamental para nove anos no município de

São Bernardo do Campo / Lara Gonzalez Gil; orientação Lisete

Regina Gomes Arelaro. São Paulo: s.n., 2012.

233 p. ils.; tabs.; anexos; apêndice

Dissertação (Mestrado - Programa de Pós-Graduação em Educação. Área de Concentração: Estado, Sociedade e Educação) - - Faculdade de Educação da Universidade de São Paulo.

1. Ensino Fundamental 2. Política educacional 3. Direito à educação 4. Gestão democrática da educação 5. Qualidade da educação I. Arelaro, Lisete Regina Gomes, orient. 
Implementação de Políticas Públicas: um estudo de caso sobre a ampliação do Ensino Fundamental para nove anos no município de São Bernardo do Campo.

Dissertação apresentada à Faculdade de Educação da Universidade de São Paulo para a obtenção do título de Mestra em Educação.

Aprovada em: de de 2012.

Banca Examinadora

Profa. Dra.

Julgamento:

Profa. Dra.

Julgamento:

Prof. Dr.

Julgamento:
Instituição:

Assinatura:

Instituição:

Assinatura:

Instituição:

Assinatura: 
Às crianças, que contagiam diariamente o mundo com sua alegria, simplicidade e nos enchem de esperança. Em especial, à minha querida sobrinha Natalia, que trouxe grande felicidade à nossa família. 


\section{AGRADECIMENTOS}

Aos meus pais, Mari e Douglas, por sempre me apoiarem, me incentivarem, estarem ao meu lado cheios de carinho e compreensão e, principalmente, pela paciência que tiveram comigo nos momentos finais da dissertação.

Às minhas irmãs, Iara e Laís, por toda a força que me deram e por sempre acreditarem que eu iria conseguir. E aos seus maridos, Maurício e Gustavo, por serem mais que cunhados, grandes amigos.

À Professora Lisete Arelaro, sou muito agradecida, por mais que me orientar, ser um exemplo de lutadora incansável e bem humorada, em defesa de uma escola pública de qualidade para todos e todas.

À Professora Bianca Correa, por me inspirar a pesquisar o tema, durante sua apresentação de trabalho na $29^{\circ}$ Reunião anual da ANPED, em 2006, e por suas contribuições a este trabalho no Exame de Qualificação, que foram determinantes para a conclusão desta dissertação.

Ao Professor Elie Ghanem, por também contribuir com este trabalho no Exame de Qualificação e em sua disciplina da Pós Graduação, "Mudança Educacional: Inovação e Reforma”, que foram de grande ajuda para a reflexão e conclusão deste trabalho.

À Secretaria Municipal de Educação de São Bernardo do Campo, em especial à Professora Cleuza Repulho, Secretária de Educação, em 2010, pela autorização da pesquisa, pela entrevista e dados concedidos e pela extrema simpatia com que fui tratada em todos os momentos.

À querida Sandra Lima, por além de ser uma grande amiga, me fazer companhia nas manhãs frias de São Bernardo do Campo, durante toda a pesquisa de campo e por sempre me ajudar, apoiar e incentivar nos momentos mais difíceis.

À todos os profissionais da escola pesquisada, que nos acolheram bem desde o início e sempre foram muito prestativos, nos ajudando e tirando dúvidas, em especial às professoras do $1^{\circ}$ ano, que abriram suas portas e compartilharam seus saberes, suas experiências, 
inseguranças e conflitos conosco. Às crianças da escola, meu muito obrigado, por serem tão carinhosas e naturais. Agradeço também, a seus pais, pela confiança para autorizar a participação delas na pesquisa e pelas opiniões divididas durante as entrevistas.

Aos colegas e amigos do Grupo de Pesquisa "Fund9", por dividirem dúvidas, angústias, inspirações, experiências, descobertas e aprendizagens, nesses seis anos de pesquisa, em especial, à Caroline Ferrarezi, por toda a ajuda e apoio dado para a conclusão desta dissertação.

Aos colegas do Grupo de Orientandos, pelas leituras e discussões que compartilhamos nesses três anos e pelo sentimento de que "não estamos sozinhos", em especial à Sylvie Klein, por me inspirar com sua dedicação e militância em defesa da escola pública e da infầncia.

A todos da EMEI Geloira de Campos, que me receberam tão bem este ano, agradeço o apoio, incentivo e a compreensão, nos momentos em que tive que me ausentar para terminar esta dissertação.

Aos meus amigos e amigas, que sempre estiveram ao meu lado, me encorajando quando precisei, mesmo estando fisicamente longe ou nos momentos em que tive que negar convites para sair, pois o prazo já estava se aproximando, meu muito obrigado, vocês são especiais! Agradeço especialmente, à Viviane Rei, por compartilhar os domingos ensolarados de leitura, escrita e reflexão sobre a educação e a vida, em sua casa. 


\section{RESUMO}

GIL, L.G. Implementação de Políticas Públicas: um estudo de caso sobre a ampliação do ensino fundamental para nove anos no município de São Bernardo do Campo 2012. 233 f. Dissertação (Mestrado) - Faculdade de Educação, Universidade de São Paulo, São Paulo, 2012.

Nesta dissertação são analisados os desdobramentos das Leis Federais $n^{0} 11.114 / 05$, que instituiu o início da obrigatoriedade do ensino fundamental aos seis anos de idade, e da Lei $n^{\circ}$ 11.274/06, que ampliou a duração do ensino fundamental para nove anos. O objetivo da pesquisa foi realizar um estudo sobre a implementação do ensino fundamental de nove anos em uma escola da rede municipal de São Bernardo do Campo, verificando a articulação da política educacional nacional, sua adequação em nível municipal e a sua efetivação no cotidiano escolar. Para tanto, foi realizada a observação em uma turma de $1^{\circ}$ ano em uma escola da rede municipal, durante todo o ano letivo de 2010. O estudo contou, ainda, com a realização de entrevistas semi-estruturadas com os diversos segmentos da comunidade escolar: Secretária Municipal de Educação, diretora, professoras, membros do Conselho de Escola, pais e, em especial, com as crianças do primeiro ano do ensino fundamental de nove anos. As considerações apresentadas são baseadas nos dados obtidos na pesquisa de campo, em dados estatísticos, na análise dos documentos oficiais e no levantamento bibliográfico sobre o tema. A análise dos dados permitiu o levantamento de opiniões dos sujeitos da Pesquisa sobre diversos aspectos da implantação do ensino fundamental de nove anos e a comparação com as intenções anunciadas nos documentos oficiais, tendo como base três princípios educacionais: direito à educação, gestão democrática e qualidade do ensino. $\mathrm{O}$ estudo realizado permite afirmar que não houve aumento no número de matrículas no município pesquisado, que a comunidade escolar não participou de discussões referentes ao tema, sendo apenas informados sobre a mudança e que a política da Secretaria Municipal de Educação apareceu pouco na escola pesquisada, tendo-se a sensação que as escolas ficaram meio sem rumo, conduzindo o trabalho com os $1^{\circ}$ anos de modo mais ou menos adequado, dependendo da "sorte" de haver profissionais mais ou menos qualificados para trabalhar com as crianças de seis anos.

Palavras-chave: ensino fundamental - política educacional (implementação) - direito à educação - gestão democrática - qualidade de ensino 


\begin{abstract}
GIL, L.G. Implementation of Public Policies: case study about the extension of basic education to nine years in São Bernardo do Campo 2012. 233 f. Dissertação (Mestrado) Faculdade de Educação, Universidade de São Paulo, São Paulo, 2012.

In this thesis the developments of Federal Law $n^{\circ} 11.114 / 05$, that instituted the beginning of the basic education at six years old and Federal Law $n^{\circ} 11.274 / 06$, that expanded the basic education to nine years of duration, are analyzed. The aim of the research was to realize a study about the implementation of nine years basic education at a São Bernardo's municipal school, checking the joint of national educational policy, the adequacy at municipal level and the effectuation at daily school. So, it was made an observation in a first year class of a municipal school, during all the year of 2010. The study also counted with semi structured interviews with the different school community segments: Secretary of Education, principal, teachers, member of School Concil, and especially the children of the first year class from the nine years basic education. The presented considerations are based on field research and statistic data, the official documents analysis and bibliography about the theme. The data analysis allowed getting the opinions from research participants about the different aspects of nine years basic education and comparing with the intentions annunciated at official documents, having as basis three educational principles: right of education, democratic management and education quality. The study allows to affirm that there was no matriculation's grow in the researched city, that the school community didn't participate in this theme discussions, being just informed about the changing and that the Municipal Secretary of Education policy almost didn't shows at the researched school, having the feeling that schools was adrift, leading the work with the children in more or less appropriate way, depending of the "luck" of having more or less qualified professionals to work with six years old children.
\end{abstract}

Key words: basic education - educacional policy - right to education - democratic management - quality education 


\section{LISTA DE ABREVIATURAS E SIGLAS}

ANPEd Associação Nacional de Pós Graduação e Pesquisa em Educação

APM Associação de Pais e Mestres

CE Conselho de Escola

CEB Câmara de Educação Básica

CEE Conselho Estadual de Educação

CENFORPE Centro de Formação dos Profissionais da Educação

CF 88 Constituição Federal de 1988

CMAPE Centro Municipal de Apoio Pedagógico Especializado

CMED Conselho Municipal de Educação

CNE Conselho Nacional de Educação

$\mathrm{CNPq}$ Conselho Nacional de Desenvolvimento Científico e Tecnológico

CPQ Centro de Qualificação Profissional

CRAS Centro de Referência e Assistência Social

CRI Centro de Referência ao Idoso

DCNs Diretrizes Curriculares Nacionais

ECA Estatuto da Criança e do Adolescente - Lei $n^{\circ}$ 8.069/90

EF8 Ensino Fundamental de Oito Anos

EF9 Ensino Fundamental de Nove Anos

EI Educação Infantil

EMEB Escola Municipal de Educação Básica

EMEBE Escola Municipal de Educação Especial

EMEI Escola Municipal de Educação Infantil

EMIP Escola Municipal de Iniciação Profissional

EOT Equipe de Orientação Técnica

ESPM Escola Superior de Propaganda e Marketing

FAPAN Faculdade PanAmérica

FASB Faculdade de São Bernardo do Campo

FATEC Faculdade de Tecnologia de São Bernardo do Campo

FEI Centro Universitário da Faculdade de Engenharia Industrial

FEUSP Faculdade de Educação da Universidade de São Paulo

FIA Fundação Instituto de Administração

FTT Faculdade de Tecnologia Termomecânica

FUNDEB Fundo de Manutenção e Desenvolvimento da Educação Básica e Valorização dos Profissionais de Educação

FUNDEF Fundo de Manutencão e Desenvolvimento do Ensino Fundamental e 
Valorização dos Profissionais do Magistério

HTPC Horário de Trabalho Pedagógico Coletivo

IBGE Instituto Brasileiro de Geografia e Estatística

IDEB Índice de Desenvolvimento da Educação Básica

IDH Índice de Desenvolvimento Humano

INEP Instituto Nacional de Estudos e Pesquisas Educacionais Anísio Teixeira

ITA Instituto Tecnológico da Aeronáutica

LDB Lei de Diretrizes e Bases da Educação Nacional

MEC Ministério da Educação

PCNs Parâmetros Curriculares Nacionais

PIB Produto Interno Bruto

PL Projeto de Lei

PMDB Partido do Movimento Democrático Brasileiro

PNE Plano Nacional de Educação

PNLD Programa Nacional do Livro Didático

PPP Projeto Político Pedagógico

PSB Partido Socialista Brasileiro

PSDB Partido da Social Democracia Brasileira

PT Partido dos Trabalhadores

PTB Partido Trabalhista Brasileiro

SAEB Sistema de Avaliação da Educação Básica

SAPDV Serviço de Apoio às Pessoas com Deficiência Visual

SEB Secretaria de Educação Básica

SME Secretaria Municipal de Educação

SUS Sistema Único de Saúde

TCC Trabalho de Conclusão de Curso

UBS Unidade Básica de Saúde

UE Unidade Educacional

UFABC Universidade Federal do ABC

UMESP Universidade Metodista de São Paulo

UNDIME União Nacional dos Dirigentes Municipais de Educação

UNIBAN Universidade Bandeirante de São Paulo

USP Universidade de São Paulo 


\section{LISTA DE TABELAS E QUADROS}

Tabela I Total das Matrículas - Educação Infantil - Rede Direta e Conveniada do 30 Município de São Bernardo do Campo (2004 - 2010)

Tabela II Total de Alunos Aprovados - Primeiros Anos do Ensino Fundamental 31 do Município de São Bernardo do Campo (2005 - 2010)

Tabela III Total de Alunos Reprovados - Primeiros Anos do Ensino Fundamental 31 do Município de São Bernardo do Campo (2005 - 2010)

Quadro I Matrícula das crianças de 5, 6 e 7 anos 46

Quadro II Idade de Matrícula na Pré-escola e no Ensino Fundamental 46

Tabela IV Total das Matrículas - Educação Infantil na Rede Municipal de 50 São Bernardo do Campo (2004 - 2010)

Tabela V Total das Matrículas - Anos Iniciais do Ensino Fundamental do 50 Município de São Bernardo do Campo (2004 - 2010)

Tabela VI Total das Matrículas - Crianças de seis anos na Rede Municipal de $\quad 51$ São Bernardo do Campo (2004 - 2010) 


\section{SUMÁRIO}

1. Introdução.

2. Material, Métodos e Forma de Análise dos Resultados

3. Caracterização do estudo de caso.

4. Reflexões sobre o ensino fundamental de nove anos e direito à educação

4.1 - O direito à educação no Brasil e o ensino fundamental de nove anos.... 38

4.2 - $\mathrm{O}$ ensino fundamental de nove anos e o direito à educação no município de São Bernardo do Campo

5. Reflexões sobre o ensino fundamental de nove anos e a gestão democrática. 55

5.1 - Gestão Democrática no Brasil e o ensino fundamental de nove anos....

5.2 - O ensino fundamental de nove anos e o princípio da gestão democrática no município de São Bernardo do Campo.

6. Reflexões sobre o ensino fundamental de nove anos e a qualidade da educação 72 6.1 - Discussão sobre qualidade da educação no Brasil e o ensino fundamental de nove anos.

6.2 - O ensino fundamental de nove anos e a qualidade da educação no município de São Bernardo do Campo

7. Considerações Finais.

10. Referências Bibliográficas

Apêndices

Anexos. 


\section{Introdução}

Eu queria ficar aqui, nessa escola, porque aqui tem brinquedoteca e lá não tinha. Não, eu queria ficar um pouco naquela e um pouco nesta, porque lá tinha uma ponte de madeira (Criança 3).

A Constituição Federal de 1988 e, posteriormente, a Lei de Diretrizes e Bases da Educação Nacional (LDB), Lei no 9.394/1996, já garantia legalmente o acesso ao ensino fundamental com duração mínima de oito anos, obrigatório e gratuito, a partir dos sete anos de idade a todos os cidadãos brasileiros.

Quando os índices apontavam que cerca de 97\% da população de 7 (sete) a 14 (catorze) anos matriculados em alguma escola, na tentativa de garantir a universalização da educação prevista em lei, outra questão já se colocava quanto ao ensino fundamental: a de sua duração. Na Lei Federal n 10.172/2001, que instituiu o Plano Nacional de Educação (PNE), aparecia como meta que o Brasil deveria: "2) Ampliar para nove anos a duração do ensino fundamental obrigatório com início aos seis anos de idade, à medida que for sendo universalizado o atendimento na faixa de 7 a 14 anos." (BRASIL, 2001, p. 6)

Em julho de 2004, o Ministério da Educação (MEC) publicou o documento "Ensino Fundamental de nove anos: orientações gerais" (BRASIL, 2004c). De acordo com a Secretaria de Educação Básica (SEB), que produziu o documento, ele foi, em grande parte, resultado de sete encontros regionais realizados em fevereiro de 2004, com a participação de diversos sistemas de ensino, onde várias questões foram levantadas e discutidas pelos gestores. Esse documento fazia inicialmente uma breve caracterização do que seria uma educação com qualidade social, afirmando que o seu objetivo era:

$\mathrm{O} \mathrm{MEC} / \mathrm{SEB} / \mathrm{DPE} / \mathrm{COEF}$ pretende, com estas orientações, construir políticas indutoras de transformações significativas na estrutura da escola, na reorganização dos tempos e dos espaços escolares, nas formas de ensinar, de aprender, de avaliar, implicando a disseminação das novas concepções de currículo, conhecimento, desenvolvimento humano e aprendizado. (BRASIL, 2004a, p. 11).

Passados quatro anos da aprovação do PNE, em maio foi promulgada a Lei Federal $\mathrm{n}^{\mathrm{o}}$ 11.114/2005 - que estabeleceu a obrigatoriedade de matrícula no ensino fundamental aos seis anos de idade, mantidos seus oito anos de duração. Esse ato legal estabeleceu que a lei entraria em vigor no início do ano letivo seguinte, ou seja, em 2006.

Segundo Arelaro (2005) essa lei trouxe alguns problemas, pois não foi sequer discutida no Conselho Nacional de Educação (CNE) e, não definia se a educação infantil, a 
partir de 2006, seria destinada às crianças na faixa etária de 0 (zero) a 5 (cinco) anos e deixava sem especificação quais instituições educacionais atenderiam essas crianças. Outro problema apontado era que "o autor da Lei parece ter pretendido transferir, simplesmente, o último ano da educação infantil, incorporando-o ao Ensino Fundamental, como se isso fosse uma passagem tranqüila e as duas instâncias educacionais fossem semelhantes." (ARELARO, 2005, p. 1047).

Correa (2007) levanta outro problema causado por essa lei:

Esta mesma lei não mencionava a obrigatoriedade de os sistemas organizarem o EF com duração de nove anos, o que, na prática, significava não um ganho, mas um prejuízo a boa parte das crianças brasileiras, já que cerca de $75 \%$ delas já estariam sendo atendidas em pré-escolas. Assim, em vez de aumentarem em um ano sua escolaridade, estariam perdendo um, já que sairiam mais cedo da EI para ingressarem aos seis anos no EF. (CORREA, 2007, p. 5).

Para tentar resolver estas questões, em 3 de agosto de 2005, o CNE editou a Resolução $\mathrm{n}^{\mathrm{o}}$. 3, que definia normas nacionais para a ampliação do ensino fundamental para nove anos de duração, com início aos seis anos de idade. Esta Resolução trazia ainda, a nomenclatura e a faixa etária atendida na educação infantil e no ensino fundamental:

\begin{tabular}{|l|l|l|}
\hline Etapa de ensino & Faixa etária prevista & Duração \\
\hline Educação Infantil & até 5 anos de idade & \\
Creche & até 3 anos de idade & \\
Pré-escola & 4 e 5 anos de idade & \\
\hline $\begin{array}{l}\text { Ensino Fundamental } \\
\text { Anos iniciais }\end{array}$ & Até 14 anos de idade & 9 anos \\
Anos finais 6 a 10 anos de idade & 5 anos \\
4 anos
\end{tabular}

Fonte: BRASIL, 2005b.

Em 06 de fevereiro de 2006, foi aprovada a Lei Federal $n^{\circ} .11 .274$, que alterou artigos da LDB e reorganizou o ensino fundamental através da ampliação de sua duração em um ano, passando de 8 (oito) para 9 (nove) anos, mantendo a obrigatoriedade do seu início aos seis anos. Esta lei previu, ainda, a implementação do ensino fundamental de nove anos nos Municípios, Estados e o Distrito Federal, até 2010.

Cabe destacar algumas experiências pedagógicas de organização do ensino fundamental, que antecederam a Lei 11.274/2006. Na década de 80, o Município do Rio de 
Janeiro/RJ incorporou as "classes de alfabetização", como eram denominadas as classes de pré-alfabetização, que atendiam crianças de seis anos no ensino fundamental, porém muitas ainda seguiam as dinâmicas das classes pré-escolares, da educação infantil. Na década de 90, o município de Belo Horizonte/MG optou por organizar o ensino fundamental em três "Ciclos de Formação", com três anos de duração cada um, sendo o $1^{\circ}$ ciclo formado por crianças de 6 a 8 anos de idade, o $2^{\circ}$, por crianças de 9 a 11 anos e o $3^{\circ}$ ciclo, por alunos de 12 a 14 anos de idade, sendo esta experiência pioneira no ensino fundamental de nove anos. Esta organização foi reformulada e adotada nas cidades de Porto Alegre/RS, Brasília/DF e Belém/PA, em gestões do Partido dos Trabalhadores (PT).

Após a aprovação da Lei 11.274, em 2006, foi publicado o documento do MEC "Orientações para a inclusão da criança de seis anos no ensino fundamental” (BRASIL, 2006d), composto por textos de diversos autores que tratam principalmente de questões como alfabetização e a importância das diversas linguagens e do lúdico na infância, para subsidiar a formação dos professores que trabalhariam com essas turmas.

Em 2009, o MEC publicou o documento "Ensino Fundamental de nove anos: Passo a Passo do Processo de Implantação" (BRASIL, 2009a) que tinha por objetivo "subsidiar gestores municipais e estaduais, conselhos de educação, comunidade escolar e demais órgãos e instituições." (BRASIL, 2009, p.5).

O documento, inicialmente trazia as normatizações para a ampliação do ensino fundamental, com o amparo legal para sua ampliação, os Pareceres do CNE sobre o assunto, as orientações para que os Conselhos Estaduais e Municipais de Educação fizessem seus Pareceres, orientações para as Secretarias de Educação e para as escolas se adequarem à esta nova organização. Em seguida, o documento tratava da questão da organização pedagógica, trazendo questões sobre currículo, afirmando que as escolas deveriam reestruturar seu Projeto Político Pedagógico, tratava da avaliação e da formação dos profissionais da educação. Por fim, apresentava as perguntas e respostas mais frequentes sobre a ampliação do ensino fundamental para nove anos.

Em julho de 2010, foi homologado o Parecer CNE/CEB n ${ }^{\circ} 11 / 2010$ que definiu as Diretrizes Curriculares Nacionais (DCNs) para o Ensino Fundamental de 9 (nove) anos. As DCNs estavam divididas em: fundamentos, princípios, matrícula no ensino fundamental de nove anos e carga horária, currículo, base nacional comum e parte diversificada, Projeto Político Pedagógico, gestão democrática, relevância dos conteúdos, integração e abordagens, articulações e continuidade da trajetória escolar, avaliação, educação em tempo integral, educação do campo, indígena e quilombola, educação especial, educação de jovens e adultos 
e a implementação destas diretrizes enquanto compromisso solidário dos sistemas e redes de ensino.

Sendo assim, a ampliação do ensino fundamental para nove anos, com a antecipação da entrada das crianças no ensino fundamental, com seis anos de idade, tem importantes e diversificadas conseqüências na organização e no cotidiano escolar, admitindo-se que as crianças de seis anos que antes eram atendidas nas escolas de educação infantil, com infraestrutura, currículo e professores formados para trabalhar com as características dessa faixa etária, passaram a ser atendidas nas escolas de ensino fundamental, que possuem uma organização diferente.

Partindo dessa constatação, a preocupação acadêmica que motivou esta pesquisa era conhecer como se deu a inclusão das crianças de cinco anos e meio e seis anos, nas escolas públicas de ensino fndamental. Como destaca Correa (2007):

Deve-se lembrar que esta parece ser uma regra em nosso sistema educacional: primeiro sanciona-se a lei, depois se corre atrás de sua viabilização e, enquanto isso, alunos e professores são, em geral, os que mais sofrem durante os períodos de "transição". (CORREA, 2007, p. 7).

É importante, então, acompanhar e avaliar como foi realizada a ampliação do ensino fundamental para nove anos e o seu impacto nas redes estaduais e municipais do Brasil e nas escolas onde essas crianças estão sendo atendidas, que contam com uma organização diferente das escolas de educação infantil. É fundamental por isso, observar como a entrada dessas crianças no ensino fundamental vem sendo realizada, se o princípio da gestão democrática está sendo colocado em prática, se os professores estão sendo formados adequadamente para assumir essa nova organização do ensino fundamental, se as escolas têm infra-estrutura e verbas suficientes para se adequar, qual currículo está sendo implementado, se o direito ao desenvolvimento integral das crianças e a melhoria da qualidade de ensino estão sendo cumpridos e quais as implicações dessa mudança para o ensino fundamental no seu conjunto.

Sendo assim, essa Dissertação faz parte da Pesquisa intitulada "Avaliando Políticas Educacionais: um estudo sobre a implantação do Ensino Fundamental de Nove Anos no Estado de São Paulo.”, realizada por grupo de pesquisadores na Faculdade de Educação da Universidade de São Paulo, com financiamento do $\mathrm{CNPq}^{1}$. O presente trabalho tem por

\footnotetext{
${ }^{1}$ Pesquisa "O Ensino Fundamental de Nove Anos no estado de São Paulo: um estudo exploratório sobre sua implementação" realizada por Caroline Ferrarezi Fernandes, Clóvis Edmar Paulino, Lara Gonzalez Gil, Profa. Dra. Márcia Jacomini, Paulo Rogério Batista, Piéra Cristine Varin, Sandra Cristina Lima da Silva, Sylvie Bonifácio Klein, Tatiane Aparecida Ribeiro, sob coordenação da Profa. Lisete Regina Gomes Arelaro da Faculdade de Educação/USP (nov/ 2009 - jun/2012).
} 
objetivo analisar a ampliação do ensino fundamental para nove anos no município de São Bernardo do Campo, por ser este um dos municípios mais ricos do país, tendo o Produto Interno Bruto (PIB) estimado em cerca de R $\$ 30$ bilhões de reais e representando 1\% do PIB nacional, em 2008, de acordo com pesquisa do Instituto Brasileiro de Geografia e Estatística (IBGE), além de ter municipalizado todo o atendimento dos anos anos iniciais do ensino fundamental, a partir de 1999, não contando, assim, com atendimento desses cinco anos na rede estadual.

O objetivo principal da pesquisa foi realizar estudo sobre a implementação do ensino fundamental de nove anos de duração, na rede de ensino municipal de São Bernardo do Campo, por meio de pesquisa bibliográfica e documental, bem como de pesquisa de campo, para tentar responder as seguintes questões:

- A ampliação de um ano do ensino fundamental ampliou a matrícula na rede?

- A comunidade escolar foi ouvida, levada em consideração na formulação dessa política pública?

- Foi realizada a discussão dessa política pública federal no sistema municipal de ensino?

- Tem havido melhoria da qualidade do ensino com o (novo) $1^{\circ}$ ano? Em que termos?

- As equipes escolares receberam orientações e ajuda (verbas, materiais, formação) para implementar essa ampliação do ensino fundamental?

- Houve acompanhamento por parte dos gestores do sistema na implementação dessa política?

- Qual a opinião da comunidade escolar sobre essa mudança, em especial, das crianças envolvidas nesta nova reorganização escolar?

Tendo como base essas questões, a pesquisa de campo ocorreu no ano de 2010, por se tratar do ano em que o município de São Bernardo do Campo optou por ampliar o ensino fundamental para nove anos e último ano do período transitório para a reorganização das redes de ensino, previsto pela Lei Federal.

A partir dos dados obtidos e da bibliografia estudada, foi decidido que três grandes critérios deveriam nortear a pesquisa: direito à educação, gestão democrática e qualidade de ensino. E, a partir deles, poderia-se avaliar a política de ampliação do ensino fundamental para nove anos e responder essas questões.

Os capítulos de direito à educação e qualidade de ensino foram escritos tendo como base as justificativas apresentadas pelo Ministério da Educação, nos diferentes documentos de 
orientação sobre o ensino fundamental de nove anos, que serão analisados posteriormente, argumentando que a ampliação teria relação com o aumento de matrículas dessa etapa de ensino e, assim, contemplando o direito à educação e a ampliação da qualidade de ensino com essa mudança.

Como afirmam Bujes e Marcello (2011):

(...) o movimento de implantação do ensino fundamental de nove anos vem sendo justificatificado a partir de dois argumento centrais, se atentarmos para aquilo que presseituam os documentos que analisamos. O primeiro, de que ele se impõe como estratégia de inclusão das crianças de seis anos na escola - pois no ano de 2000 (pelo Censo IBGE) apenas $81,7 \%$ das crianças dessa faixa etária estavam na escola e $29,6 \%$ já frequentavam o ensino fundamental - e outro, ao tão proclamado quanto obscuro propósito de garantir isso que se tem chamado de qualidade da educação. Portanto, os motes de mudança na estrutura do ensino fundamental centram-se em dois conceitos largamente utilizados hoje no campo das discussões políticas, sociais, educacionais: inclusão é qualidade. (BUJES; MARCELLO, 2011, p. 62).

Serão analisados no capítulo de direito à educação se, com a entrada das crianças de seis anos no ensino fundamental, houve aumento no atendimento das crianças de zero a cinco anos na educação infantil ou se as matrículas mantiveram-se estáveis, além de verificar se os novos alunos no $1^{\mathrm{o}}$ ano estavam fora da escola ou se já frequentavam a educação infantil. Além disso, será descrita e analisada a opinião da comunidade escolar sobre a obrigatoriedade da matricula no ensino fundamental. No capítulo de qualidade de ensino serão descritas e analisadas as mudanças ocorridas na escola pesquisada no estudo de campo para receber as crianças de seis anos no $1^{\circ}$ ano (rotina, espaço físico, formação dos professores, proposta curricular, entre outros) e se elas eram coerentes com as propostas governamentais de garantia da qualidade do ensino. Por último, serão apresentadas as opiniões dos envolvidos.

No capítulo de gestão democrática, procurou-se verificar, a partir das opiniões dos diferentes segmentos da comunidade escolar (gestores, professores, pais e crianças), se eles participaram das discussões referentes à ampliação do ensino fundamental para nove anos, se receberam orientação e qual sua opinião sobre essa mudança. Neste sentido tratou-se de investigar por quais instâncias as discussões sobre o ensino fundamental de nove anos teriam sido feitas para que fossem realizadas as adequações e orientações pedagógicas realizadas pela escola em relação às alterações exigidas pela nova legislação de organização do ensino fundamental. Outro objetivo foi identificar se o Conselho de Escola foi envolvido e qual o âmbito de decisão que teve e, ainda, pesquisar se havia elaborado um novo Projeto Político Pedagógico pela escola, em função das novas orientações e se havia sido discutido com a comunidade escolar. 


\section{Material, Métodos e Forma de Análise dos Resultados}

Primeiro a gente entra, guarda o material e começa a fazer as lições, depois que a gente faz a lição, a gente almoça, vai no parque e depois a gente volta para sala para fazer lição. E quando acaba a gente brinca. (Crianças 1 e 3)

A pesquisa foi realizada por meio de metodologia qualitativa, incluindo um estudo de caso, sendo previsto um estudo documental e bibliográfico, bem como o estudo de campo. $\mathrm{O}$ estudo documental implicou no levantamento dos atos legais federais, estaduais (SP) e municipais (São Bernardo do Campo) sobre a ampliação do ensino fundamental para nove anos e dos documentos oficiais sobre esse assunto (dentre eles os do MEC, do CNE, do CEE, do CME, da SME, etc.). Além disso, analisou-se os documentos constantes nos sites oficiais. Sobre a reorganização escolar a pesquisa contou, ainda, com levantamento bibliográfico sobre o tema.

Para verificar como se dão as políticas públicas educacionais no seu principal lócus de atuação - as escolas - optou-se por fazer um trabalho de campo em uma escola municipal de São Bernardo do Campo visando analisar a implementação dessa política de âmbito federal numa escola ${ }^{2}$. Para isso foi selecionada uma escola em um bairro pobre do município, onde a pesquisadora fez contato no início de 2010 e obteve autorização para a pesquisa. Além disso, o Projeto de Pesquisa foi entregue à Secretaria Municipal de Educação que também autorizou a participação da escola na pesquisa, sendo a própria Secretária de Educação posteriormente entrevistada.

No mês de março de 2010, teve início a ida da pesquisadora à escola para acompanhar as mudanças e adequações planejadas e efetuadas para receber as crianças de seis anos no ensino fundamental, o acompanhamento de reuniões sobre o tema, as discussões ocorridas na escola, a leitura dos documentos da escola, além de acompanhar a rotina de uma turma de $1^{\circ}$ ano da escola, no período da manhã, durante todo o ano de 2010. O registro das atividades e das falas dos diversos atores envolvidos foram registrados em um Caderno de Campo. Sempre que autorizadas, as atividades escolares foram fotografadas, bem como as dependências da escola em que elas aconteceram.

Como a rede municipal de São Bernardo do Campo optou por manter as duas organizações do ensino fundamental (de oito e de nove anos), no ano de 2010, a pesquisadora decidiu acompanhar, também, alguns dias letivos na turma do $1^{\circ}$ ano do ensino fundamental

\footnotetext{
2 As entrevistas e as observações da escola pesquisada foram realizadas com a ajuda da pesquisadora e professora Sandra Cristina Lima da Silva, integrante do projeto "O Ensino Fundamental de nove anos no estado de São Paulo: um estudo exploratório sobre sua implementação".
} 
de oito anos, para analisar as semelhanças e diferenças no trabalho desenvolvido pelas duas turmas. Além disso, foram mantidas conversas informais com as professoras e foram observadas as turmas em diversos momentos, pois essas turmas realizavam algumas atividades junto com os $1^{\circ}$ anos do ensino fundamental de nove anos.

A metodologia da pesquisa previa, ainda, que no trabalho de campo fossem realizadas entrevistas $^{3}$ com diversos segmentos da comunidade escolar. Foram entrevistadas 9 (nove) pais de crianças do primeiro ano, (duas) professoras de primeiro ano de nove anos, sendo que uma das professoras respondeu às perguntas por escrito, pois durante a gravação da entrevista ela se sentiu muito nervosa, afirmando que, por ser efetiva no Estado e conveniada com a Prefeitura, tinha medo de que fosse "devolvida" ao Estado por causa de suas respostas, mesmo tendo sido avisada de que o nome da escola e dos participantes seriam mantidos em sigilo. Também foram entrevistadas: a professora da sala de informática, a diretora, a vicediretora e 3 (três) conselheiros do Conselho de Escola e que representavam segmentos distintos na comunidade escolar. Os entrevistados, com exceção da Secretária de Educação Municipal, terão seus nomes mantidos em sigilo e identificados pelo cargo que ocupavam, sendo, no caso das professoras do $1^{\circ}$ ano do ensino fundamental de nove anos, identificadas através de numeração: Professora 1 e Professora 2, os pais numerados de 1 a 9 e as crianças de 1 a 17.

As entrevistas foram realizadas no $2^{\circ}$ semestre de 2010, nos meses de outubro e novembro, quando a comunidade escolar já estava mais familiarizada com a pesquisadora, com exceção da professora da sala de informática que foi entrevistada em março de 2011, para que as informações sobre a rotina escolar fossem mais completas. As entrevistas foram realizadas a partir de um Roteiro-Base ${ }^{4}$ e gravadas, com prévia autorização dos entrevistados. Foi entrevistada também a Secretária Municipal de Educação, Professora Cleuza Repulho, em março de 2011, buscando obter informações complementares sobre a implementação no município pesquisado, além de conhecer as propostas da Secretaria de Educação para dar continuidade ao processo de implementação, bem como conhecer a opinião pessoal da Secretária quanto ao tema.

Optou-se ainda, na pesquisa de campo, por realizar entrevistas coletivas com as crianças da sala do $1^{\mathrm{o}}$ ano do ensino fundamental de nove anos acompanhada pela pesquisadora, pois de acordo com Campos:

\footnotetext{
${ }^{3}$ Os termos de autorização para realização da pesquisa de campo e das entrevistas com a direção, professoras e crianças, que foram autorizadas por seus pais, constituem o Apêndice A.

${ }^{4} \mathrm{O}$ Roteiro-Base das entrevistas constitui o Apêndice B.
} 
As informações que as crianças podem oferecer são relevantes não apenas para se conhecer melhor o que se passa nas instituições que deveriam acolher todas as crianças, cuidando-as e educando-as com respeito, mas tambémpara entender como elas vêem, como se sentem, o que temem e o que desejam na sua experiência educativa. (CRUZ in CAMPOS, 2006, p. 35).

Para entrevistar as crianças foi utilizada uma metodologia assemelhada a de grupo focal, sendo realizados quatro grupos, com 4 a 5 crianças em cada grupo, totalizando 20 crianças. A opção pela realização da entrevista em grupos, partiu da leitura do artigo acima, por: "deixar as crianças mais confortáveis diante do entrevistador, (...) propiciar maior participação das crianças, pois o que é dito pelos integrantes do grupo individualmente poderia estimular os demais a complementarem a opinião dada ou desencadear uma discussão." (CRUZ in CAMPOS, 2006, p. 36). Para realizar o registro da entrevista, os grupos foram filmados, com autorização dos pais, para posterior trancrição, assim como as demais entrevistas.

A entrevista foi realizada durante o horário de aula, em uma sala da escola que não era utilizada no período da manhã. A pesquisadora escolheu as crianças para entrevista, junto com a professora da sala, levando em consideração as crianças que ficavam mais a vontade com a pesquisadora e que gostavam de falar mais, além disso, respeitou-se a opinião da criança, perguntando se elas queriam participar da entrevista.

Durante a entrevista, a pesquisadora iniciava a conversa explicando que tinha um amigo chamado Sebastião, que tinha 6 anos e que iria entrar na escola no ano seguinte, mas estava com medo, pois nunca tinha ido à escola. Então perguntava se as crianças poderiam ajudá-lo contando um pouquinho sobre sua escola. A partir dessa história, perguntou-se: como era a escola, do que as crianças gostavam e do que não gostavam na escola que estudavam e o que mudariam na escola, se pudessem. Perguntou-se, ainda, se elas haviam estudado em outra escola, como era essa escola, em qual das duas preferiam ficar e, por último, se elas acreditavam que as crianças de seis anos deveriam ir à escola e porquê. No final pediu-se que elas fizessem um desenho da escola para que a pesquisadora pudesse entregar para seu amigo Sebastião.

Após a realização das entrevistas, elas foram transcritas ${ }^{5}$ e analisadas juntamente com as anotações da pesquisadora sobre as dependências da escola, a rotina do $1^{\mathrm{o}}$ ano e outras informações e dados obtidos. As reflexões foram realizadas à luz dos atos legais, dos documentos oficiais e da bibliografia levantada sobre a ampliação do ensino fundamental e do

\footnotetext{
${ }^{5}$ A trancrição das entrevistas constitui o Apêndice C.
} 
conceito de infância, levando-se em conta as características e direitos das crianças de cinco e seis anos.

Além das entrevistas realizadas, a Secretaria Municipal de Educação forneceu dados de matrícula, aprovação e reprovação da rede de ensino, no período de 2004 a 2010. Este ano (2004) foi escolhido por ser o ano de publicação do primeiro documento do MEC sobre o ensino fundamental de nove anos e, o de 2010, o ano de realização da pesquisa de campo e implementação da ampliação do ensino fundamental na rede pesquisada. Os dados fornecidos foram registrados e analisados, juntamente com os demais dados obtidos através da pesquisa de campo, das entrevistas realizadas e do levantamento bibliográfico.

Os resultados encontrados foram analisados a partir das medidas pedagógicas, administrativas e políticas adotadas pela Secretaria Municipal de Educação, da análise das novas propostas pedagógicas elaboradas pela escola, e pelo acompanhamento do desenvolvimento na mesma, além das implicações geradas para o ensino fundamental como um todo. Foi verificado, ainda, se os pais, professores e o corpo dirigente da escola receberam orientações sobre a nova organização escolar, analisando seus mecanismos e estratégias e a opinião dos sujeitos envolvidos sobre essa nova organização do ensino fundamental, em especial a das crianças, por serem estas os principais sujeitos envolvidos na mudança e que, muitas vezes, sequer são consideradas no processo de implementação de novas políticas.

A análise dos dados permitiu o levantamento de opiniões dos sujeitos da Pesquisa sobre diversos aspectos da implantação do ensino fundamental de nove anos e a comparação com as intenções anunciadas nos documentos oficiais, tendo como base os três eixos citados anteriormente: direito à educação, gestão democrática e qualidade de ensino. 


\title{
3. Caracterização do estudo de caso
}

\author{
A gente brinca, faz bastante lição, pinta, vai para o almoço, depois vai para o \\ parque, continua fazendo lição, ajuda a professora e no final da aula a gente pode \\ brincar um pouco. (Crianças 5,7 e 8)
}

Neste capítulo, será localizado o estudo de caso da pesquisa: uma escola do município de São Bernardo do Campo. Para isso, será analisada brevemente a política educacional de ampliação do ensino fundamental do Estado de São Paulo. Em seguida, será caracterizado o município pesquisado e sua rede de ensino e, por último, será apresentada a escola pesquisada, bem como seu Projeto Político Pedagógico (PPP).

\section{O Ensino Fundamental de nove anos no Estado de São Paulo ${ }^{6}$}

Em São Paulo, a primeira publicação do Conselho Estadual de Educação (CEE) sobre a ampliação do ensino fundamental para nove anos e a entrada obrigatória das crianças aos seis anos de idade nessa etapa de ensino foi a Indicação CEE/CEB n ${ }^{0}$ 52/2005. Ela reforçava que a adoção da Lei 11.114/2005, por si só, significaria uma perda para as crianças, já que a maioria, no Estado, já frequentava a educação infantil. Um aspecto importante dessa Indicação é que ela dispunha que o $1^{\circ}$ ano deveria ser mais parecido com o que era realizado na educação infantil, do que com o que era realizado nos outros quatro anos do ensino fundamental: " $\mathrm{O} 1^{\circ}$ ano deverá manter sua identidade pedagógica e de instalações muito mais próxima dos dois últimos anos da educação infantil dos que dos quatro restantes da primeira afse do ensino fundamental.” (SÃO PAULO, 2005)

Porém, apesar de trazer essa preocupação e definir a "data-corte" para matrícula no $1^{\circ}$ ano em 2006, em 31 de dezembro de 2005, ela permitia que as escolas ou redes de ensino estabelecessem normas que possibilitassem a entrada de crianças com menos de seis anos nessa etapa de ensino.

Em 2006, após a aprovação da Lei 11.274/2006, o CEE de São Paulo, através da Deliberação $n^{0}$. 61/2006, fixou as normas para a implementação do ensino fundamental de nove anos no Sistema de Ensino do Estado. A Deliberação permitiu que a ampliação se desse

\footnotetext{
${ }^{6}$ Este item foi escrito, a partir das referências constantes do trabalho de RIBEIRO, T. A. A implementação do ensino fundamental de nove anos na rede estadual de São Paulo: um estudo de caso. 2011, 212p. Trabalho de Conclusão de Curso (Pedagogia) - Faculdade de Educação, Universidade de São Paulo, São Paulo, 2011. Pesquisadora participante da pesquisa já mencionada.
} 
de forma imediata ou progressiva, mas, impreterivelmente, até 2010, como estabelecido na lei federal.

Além disso, a partir de 2010, os alunos com sete anos, que não tivessem cursado a educação infantil, deveriam ser matriculados no $2^{\circ}$ ano do ensino fundamental, atentando-se, neste caso, para as eventuais necessidades e/ou dificuldades apresentadas pelo aluno. É importante destacar que o artigo $5^{\circ}$, parágrafo $2^{\circ}$, da Deliberação $n^{\circ} 61$, permitia a entrada de crianças com menos de seis anos: "Admite-se a possibilidade de acesso ao Ensino Fundamental de crianças com seis anos incompletos se prevista nos Regimentos Escolares e mediante a avaliação da equipe técnico-pedagógica da Instituição.” (SÃO PAULO, 2006a).

A Deliberação trazia medidas que deveriam ser adotadas pelos sistemas de ensino para a implantação do ensino fundamental de nove anos, como por exemplo, a reorganização curricular e pedagógica de toda estrutura desse nível de ensino; a organização dos tempos e o redimensionamento dos espaços e ambientes escolares; a manutenção do docente sempre que possível com o mesmo grupo-classe na etapa destinada ao processo de alfabetização; o estabelecimento de programas de formação continuada de professores e demais profissionais, entre outras. $\mathrm{O}$ artigo $7^{\circ}$ destacava, ainda, a importância da construção de uma Proposta Pedagógica que atentasse para uma articulação entre as características da educação infantil e dos anos iniciais do ensino fundamental.

Em 2008, essa Deliberação foi revogada pela Deliberação CEE $n^{0}$ 73, que regulamentou a implantação do ensino fundamental de nove anos no âmbito da rede estadual de esnino, alterando a "data-corte" da Deliberação anterior, definindo em seu artigo $2^{\circ}$ que: "O Ensino Fundamental é direito público subjetivo e a ele tem acesso todas as crianças a partir dos seis anos de idade, completados até 30 de junho do ano do ingresso". (SÃO PAULO, 2008a). Assim, a partir dessa Deliberação, o CEE não só permitiu, como estimulou, a entrada de crianças menores de seis anos no ensino fundamental.

No mesmo ano, o CEE publicou a Indicação CEE/CEB $n^{\circ} 76$, com o objetivo de responder a dúvidas sobre a implementação no ensino fundamental de nove anos. Essa Indicação também trazia questões sobre a "data-corte" para matrícula no $1^{\circ}$ ano.

Sobre esta questão Ribeiro (2011) afirma que:

Desta forma, apesar do Conselho Nacional de Educação (CNE) ter afirmado várias vezes que a matrícula das crianças no ensino fundamental de nove anos se daria com seis anos completos ou a completar até o início do ano letivo (31 de março do ano em que ocorrer a matrícula), esta não foi a orientação encontrada nas normatizações do CEE. (RIBEIRO, 2011, p. 28) 
Sendo assim, antes da ampliação do ensino fundamental para nove anos na rede estadual de ensino do Estado de São Paulo, assim como em alguns de seus municípios, que seguiram esta Deliberação, as crianças estavam entrando no ensino fundamental antes dos seis anos de idade, perdendo um ano da educação infantil, sem, se quer, ficar nove anos no ensino fundamental e, com isso, tendo seu direito à educação prejudicado. Posteriormente, será analisado se este foi o caso no município pesquisado.

\section{Características Gerais do Município de São Bernardo do Campo}

São Bernardo do Campo é um município do estado de São Paulo, inserido na região metropolitana da capital, na região conhecida como ABCD (fazem parte dessa região: Santo André, São Bernardo, São Caetano e Diadema), região das mais industrializadas do Estado.

Figura 1 - Mapa da Grande São Paulo

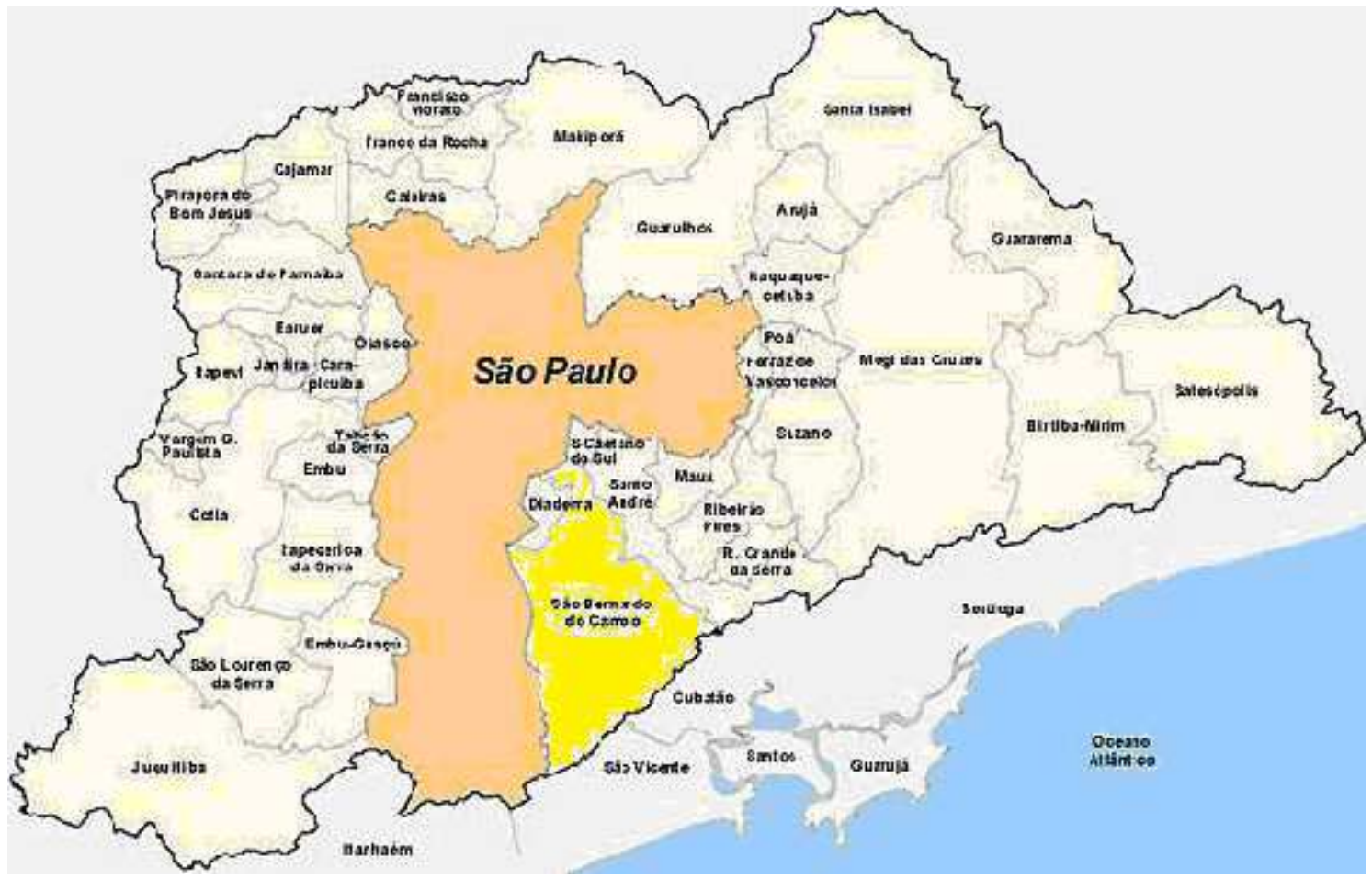

Fonte:http://www.sp-turismo.com/imagens/mapa/grande-saopaulo.jpg\&imgrefurl=http://www.spturismo.com

O Município nasceu na Borda do Campo, mesma região onde existiu a 'Villa' de Santo André da Borda do Campo ( 1550 - 1560 ). Sendo a região local de passagem para aqueles que se dirigiam ao Porto de Santos, em especial as "tropas" de mercadores que ali faziam 
pouso, começou a desenvolver um povoado na fazenda dos Monges Beneditinos, ao redor de uma capela por eles construída em 1717, região do atual Bairro Rudge Ramos. O nome - São Bernardo - deve-se a denominação dada pelos Monges Beneditinos, em homenagem ao Santo protetor da Capela.

Tendo-se formado e crescido em terras particulares dos Beneditinos, o povoado não pode ser oficializado, sendo por isso transferido para outro trecho do velho Caminho do Mar, onde está hoje a Igreja Matriz. Esta transferência do povoado ocorreu em princípios do século XIX. Ali, em 1812, de subúrbio da Capital, o povoado foi elevado à categoria de Freguesia.

Em 1877 é instalado, nas terras desapropriadas da fazenda dos Beneditinos, o Núcleo Colonial de São Bernardo, que vai dar nova vida a 'Villa'. Ao final do século, por lei provincial de 12 de março de 1889, a Freguesia foi elevada a Município, cuja instalação ocorreu em maio de 1890. O Município compreendia, então, praticamente todo o território do atual $\mathrm{ABC}$.

Com a exploração da madeira, as serrarias apareceram, registrando a tendência industrial da "Villa". Desenvolveu-se a indústria moveleira ao lado da têxtil dando início à expansão do processo de urbanização. Os bairros foram se formando e se desdobrando em pequenas vilas e novos bairros, que transformaram a paisagem do povoado em Cidade.

Em 1938, Santo André começa a se destacar econômica e politicamente, tornando-se a sede do Município. O nome do município é mudado para Santo André e São Bernardo tornase distrito. Após muitas movimentações, em 1944 ocorreu a emancipação políticoadministrativa de São Bernardo. O designativo 'do Campo', aplicado a São Bernardo, surge da instalação do atual município, em $1^{\circ}$ de janeiro de 1945. O Aniversário de São Bernardo do Campo é comemorado em 20 de agosto, por ser o dia do santo padroeiro São Bernardo. (SÃO BERNARDO DO CAMPO, 2011a).

A área total do município é de 408,45 $\mathrm{km}^{2}$ e sua população estimada, em 2010, segundo o IBGE, de 746.718 habitantes. A densidade demográfica é $1,96 \mathrm{hab} / \mathrm{km}^{2}$ e a expectativa de vida é de 74 anos. O Índice de Desenvolvimento Humano (IDH) do munícipio é 0,834 sendo considerado elevado, pois a escala do IDH vai de 0 a 1 , sendo a cidade considerada mais desenvolvida quanto mais próxima do valor 1 estiver. São Bernardo do Campo está entre os 100 municípios brasileiros com o IDH mais elevado. De acordo com pesquisa do Instituto Brasileiro de Geografia e Estatística (IBGE), em 2008, foi considerado um dos municípios mais ricos do país, tendo o Produto Interno Bruto (PIB) sido estimado em cerca de 30 bilhões de reais, representando $1 \%$ do PIB nacional. 
O município tem sua economia baseada na indústria automobilística, desde a década de 1950. As empresas multinacionais Scania, Toyota, Ford, Mercedes-Benzs, Volkswagen e Karmann Ghia, primeiras montadoras do país, escolheram o município para suas sedes. Também outras industrias multinacionais, tais como: a Tintas Basf e a gigante ColgatePalmolive ali se instalaram.

O comércio é variado, destacando-se o da Rua Marechal Deodoro e o Centro Moveleiro da Rua Jurubatuba, o que dá a São Bernardo do Campo a denominação de "Capital do Móvel”. O município também tem o maior número de Universidades do ABCD, sendo elas: Universidade Federal do ABC (UFABC), Faculdade de Tecnologia Termomecânica (FTT), Faculdade SENAI de Tecnologia Ambiental, Centro Universitário da Faculdade de Engenharia Industrial (FEI), Faculdade de Tecnologia de São Bernardo do Campo (FATEC), Faculdade PanAmérica (FAPAN), Faculdade de São Bernardo do Campo (FASB), Faculdade Anchieta, Faculdade de Direito de São Bernardo do Campo, Universidade Metodista de São Paulo (UMESP), Seminário Presbiteriano Conservador, Universidade Bandeirante de São Paulo (UNIBAN), Fundação Instituto de Administração (FIA), Escola Superior de Propaganda e Marketing (ESPM), Instituto Tecnológico da Aeronáutica (ITA) (SÃO BERNARDO DO CAMPO, 2011b)

\section{Características da Rede de Ensino}

As primeiras escolas no município de São Bernardo do Campo foram constituídas sob a administração do Prefeito Lauro Gomes de Almeida - Gestão de 1960 a 1964 - do Partido Trabalhista Brasileiro (PTB), para oferecer atendimento escolar às crianças de 0 a seis anos, a partir de 1960, pelo Departamento de Educação e Cultura, através de Jardins da Infância e Parques Infantis.

A partir de 1979, na Gestão de Antônio Tito Costa - 1977 a 1982-, do Partido do Movimento Democrático Brasileiro (PMDB), elas foram transformadas em Escolas Municipais de Educação Infantil, para crianças de quatro a seis anos e em Creches, sob responsabilidade do Departamento de Promoção Social, para crianças de 4 meses a 3 anos e 11 meses. Pela primeira vez, o município assumiu o serviço das creches, até então conduzida por instituições assistenciais, como resultado da pressão da comunidade sobre a Prefeitura.

Sob a administração do prefeito Maurício Soares do Partido dos Trabalhadores (PT) Gestão 1989 a 1992 - foram realizadas diversas mudanças na educação, a partir da década de 
1990, e mais precisamente, com a elaboração de currículo próprio, em 1992. Nesse período, o Departamento foi transformado em Secretaria de Educação e Cultura, e sob a Presidência do Professor Luís Roberto Alves, realizou concurso interno para estruturar a Equipe Técnica e ampliar o número de profissionais que pudessem oferecer suporte pedagógico à educação infantil no Município de São Bernardo do Campo.

No âmbito mais abrangente das políticas educacionais, esse currículo expressou a perspectiva de uma educação democrática, atenta aos problemas humanos sociais:

\footnotetext{
“A massificação de um modelo capitalista que ignora a natureza, privilegiando o produto e a mecanização, tornou os indivíduos extremamente competitivos, individualistas e alienados, não se percebendo como parte de um todo e desconsiderando as conseqüências de sua própria ação no ambiente" (SÃO BERNARDO DO CAMPO, 1992, p.13 apud SARTÓRIO, 2008, p. 8 ). ${ }^{7}$
}

O documento trazia comentários acerca das condições educacionais daquele período e o descaso com que as Administrações Municipais anteriores trataram a educação e a formação de professores:

É claro que a escola, como parte dessa sociedade, sofreu com a ausência de uma política que garantisse a qualidade no trabalho educacional realizado, produzindo o empobrecimento dos conteúdos didáticos, o descaso com a formação dos professores, o abandono da manutenção da própria educação. Não é apenas o professor que deseja reverter hoje esse quadro. Porém a reversão não é tarefa fácil, uma vez que demanda conhecer as causas e os interesses que levaram a essa situação e, ainda, lidar com questões que não estão, imediatamente, ao nosso alcance (SÃO BERNARDO DO CAMPO, 1992, p.13 apud SARTÓRIO, 2008, p. $8){ }^{8}$

Naquela Gestão foi montada uma comissão provisória de coordenadores pedagógicos para auxiliar nas discussões regionais junto aos professores. Depois ocorreu um concurso interno para efetivação e ampliação da Equipe Técnica, o que tornou possível, nos anos de 1993 e 1994, na Gestão de Walter Demarchi - 1993 a 1996 - do PTB, a realização de discussões em torno do currículo com os professores de cada escola do município.

No ano de 1996, com a incorporação das orientações presentes nos Parâmetros Curriculares Nacionais (PCNs), elaborados pelo Governo Federal, começaram a se manifestar os sinais da grande mudança que estaria por vir no âmbito das diretrizes educacionais, bem como na própria estrutura da Secretaria de Educação.

\footnotetext{
7 SÃO BERNARDO DO CAMPO. Secretaria de educação, Cultura e Esportes. Currículo. Prefeitura do Município de São Bernardo do Campo, 1992. Paginação desconhecida.

${ }^{8}$ Idem.
} 
Decidiu-se pela municipalização das séries iniciais do ensino fundamental, chamado Ciclo I (1ª a ${ }^{\text {a }}$ séries), a partir de 1998, na Gestão de Maurício Soares - 1997 a 2000 - do Partido da Social Democracia Brasileira (PSDB), sob a condução do Secretário de Educação, Cultura e Esportes, Admir Ferro, tendo sido ampliada, consideravelmente, a quantidade de cargos de auxiliares e das equipes técnicas da Secretaria, que se dividiu em: Equipe de Orientação Técnica Infantil (EOT - Infantil), Equipe de Orientação Técnica Fundamental (EOT - Fundamental), Educação de Joves e Adultos (EJA), e Educação Especial. Além disso, com a municipalização houve transferência das escolas estaduais para o município: prédio, infra-estrutura e pessoal. A Prefeitura aceitou incorporar a proposta do Estado de São Paulo de municipalizar o ensino fundamental, todavia, os professores da rede estadual continuaram a receber salário pela Secretaria do Estado de São Paulo, com complementação pelo município, sempre que os salários fossem mais baixos que os do município.

No mesmo período, as Escolas Municipais de Educação Infantil (EMEI’s) transformaram-se em Escolas Municipais de Ensino Básico (EMEB’s), envolvendo creches (que voltaram para a Secretaria Municipal de Educação após a LDB nº 9394/96), escolas de educação infantil e escolas de ensino fundamental I. E, de certo modo, passaram a ser subordinadas ao ensino fundamental, a partir da municipalização, ao aproximar os objetivos oferecidos pelas duas etapas de ensino. Foi estabelecida, como meta, a alfabetização das crianças aos seis anos, bem como a formação de educadores por meio do Curso "Professores Alfabetizadores" (PROFA), oferecido pelo MEC, e com monitoramento da Secretaria de Educação Cultura e Esportes. Essa meta demonstra a preocupação da Secretaria de Educação com a alfabetização das crianças pequenas.

Em 2001, Maurício Soares foi reeleito prefeito pelo Partido Socialista Brasileiro (PSB), mas pediu afastamento do cargo, em 2003, por motivos de saúde, deixando a Prefeitura para o vice-prefeito William Dib, do mesmo Partido. A partir desse ano, o controle da Secretaria de Educação do processo de alfabetização das crianças, tornou-se mais intenso, por meio das avaliações bimestrais das hipóteses de escrita das crianças, que as escolas deveriam encaminhar para a Secretaria de educação, avaliações estas que serão analisadas posteriormente. William Dib foi reeleito em 2004, ficando no comando da Prefeitura de São Bernardo do Campo até 2008, dando continuidade a política educacional dos anos anteriores.

Em 2009, com o retorno do PT, na Gestão de Luiz marinho - 2009 a 2012 - a Secretaria de Educação, dirigida pela Professora Cleuza Rodrigues Repulho, além das escola municipais, tinha como unidades administrativas sob sua responsabilidade: o Centro de Formação dos Profissionais da Educação (CENFORPE), o Complexo Padre Aldemar 
Moreira, que era dedicado ao atendimento de crianças, jovens e adultos com diferentes necessidades educativas especiais e constituído pelo Centro Municipal de Apoio Pedagógico Especializado (CMAPE), pela Escola Municipal de Educação Especial (EMEBE) Rolando Ramacciotti e pelo Serviço de Apoio às Pessoas com Deficiência Visual (SAPDV) Nice Tonhozi Saraiva.

No Portal da Educação do Município foram encontradas as seguintes atribuições da Secretaria de Educação:

\section{Do Campo Funcional}

Constitui campo funcional da Secretaria de Educação a administração do Sistema Municipal de Ensino e de assistência ao escolar.

\section{Da Competência dos Órgãos}

A Secretaria de Educação tem as seguintes competências:

I - administrar o Sistema Municipal de Ensino e de assistência ao escolar:

a) dispor sobre normas complementares para o aperfeiçoamento permanente do Sistema Municipal de Ensino;

b) promover o desenvolvimento do ensino, incentivando a integração entre a escola e a comunidade;

c) promover o intercâmbio de informações e de assistência técnica bilateral, com instituições públicas e privadas, nacionais e internacionais;

d) proporcionar assistência ao escolar;

e) definir as diretrizes para a elaboração do Plano Municipal de Ensino. (SÃO BERNARDO DO CAMPO, 2011a)

Em 2010, a rede municipal era formado por 69 (sessenta e nove) Escolas Municipais de Educação Básica (EMEBs), 3 (três) Escolas Municipais de Educação Especial (EMEBEs), 11 (onze) Escolas Municipais de Educação Profissional (EMs) e (um) Centro de Qualificação Profissional (CQP).

O Município contava, também, com Rede Conveniada para o atendimento de uma parcela das matrículas na educação infantil, conforme exposto na Tabela I:

Tabela I - Total das Matrículas - Educação Infantil - Rede Direta e Conveniada do

Município de São Bernardo do Campo (2004 - 2010)

\begin{tabular}{|l|l|l|l|l|l|l|l|}
\hline Rede de Ensino/ Ano & 2004 & 2005 & 2006 & 2007 & $2008^{9}$ & 2009 & 2010 \\
\hline Rede direta & 27121 & 28835 & 27645 & 27692 & nc & 29814 & 28567 \\
\hline Rede conveniada & nc & nc & nc & nc & nc & 2756 & 2785 \\
\hline Total & 27121 & 28835 & 27645 & 27692 & nc & 32564 & 31352 \\
\hline
\end{tabular}

Fonte: Secretaria Municipal de Educação de São Bernardo do Campo

Obs: $\mathrm{nc}=$ nada consta

\footnotetext{
${ }^{9}$ A Secretaria Municipal de Educação informou não ter os dados da Matrícula de 2008, sendo assim, as Tabelas I, IV, V e VI ficarão sem os dados de 2008.
} 
A partir da Tabela I, pode-se perceber um pequeno aumento na matrícula da Rede conveniada de 2009 para 2010 (vinte e nove matrículas), enquanto há queda de mais de mil matrículas na Rede direta de ensino, no mesmo período. Essa queda no número de matrículas da educação infantil será melhor analisada posteriormente.

No município de São Bernardo do Campo, a educação infantil estava organizada da seguinte forma: Berçário (até 1 ano), Infantil I (de 1 a 2 anos), Infantil II (de 2 a 3 anos), Infantil III (de 3 a 4 anos), Infantil IV (de 4 a 5 anos) e Infantil V (de 5 a 6 anos).

Os anos iniciais do ensino fundamental, em 2010, estavam organizados em Ciclos de Aprendizagem, sendo compostos por dois ciclos:

- Ciclo I: $1^{\circ}, 2^{\circ}$ e $3^{\circ}$ anos;

- Ciclo II: $4^{\mathrm{o}}$ e $5^{\mathrm{o}}$ anos.

Poderia haver reprovação por aprendizagem insuficiente nos anos finais de cada ciclo dos anos iniciais do ensino fundamental, portanto, nos $3^{\circ}$ e $5^{\circ}$ anos, ou por frequência insuficiente das crianças à escola, sendo o mínimo exigido de $50 \%$ de frequência em relação ao total de dias letivos, em todos os anos. Os dados de aprovação e reprovação de alunos estão apresentados nas Tabelas II e III:

Tabela II - Total de Alunos Aprovados - Primeiros Anos do Ensino Fundamental do Município de São Bernardo do Campo (2005 - 2010)

\begin{tabular}{|l|l|l|l|l|l|l|}
\hline Anos Iniciais / Ano & 2005 & 2006 & 2007 & 2008 & 2009 & 2010 \\
\hline 1o ano & & - & - & - & - & 5630 \\
\hline 2o ano & 11105 & 11428 & 11051 & 9685 & 9620 & 4655 \\
\hline 3o ano & 12052 & 11130 & 11544 & 10981 & 10213 & 9387 \\
\hline 4o ano & 11344 & 11884 & 11284 & 11180 & 11151 & 9833 \\
\hline 5o ano & 11691 & 11020 & 11905 & 10943 & 11528 & 10907 \\
\hline Total & 46192 & 45462 & 45784 & 42789 & 42512 & 40412 \\
\hline
\end{tabular}

Fonte: Secretaria Municipal de Educação de São Bernardo do Campo

Tabela III - Total de Alunos Reprovados - Primeiros Anos do Ensino Fundamental do Município de São Bernardo do Campo (2005 - 2010)

\begin{tabular}{|l|l|l|l|l|l|l|}
\hline Anos Iniciais/ Ano & 2005 & 2006 & 2007 & 2008 & 2009 & 2010 \\
\hline 1o ano & - & - & - & - & - & 25 \\
\hline 2o ano & 116 & 152 & 128 & 92 & 74 & 30 \\
\hline 3o ano & 423 & 413 & 426 & 424 & 370 & 934 \\
\hline 4 ano & 61 & 75 & 81 & 67 & 62 & 45 \\
\hline 5o ano & 285 & 275 & 313 & 292 & 273 & 450 \\
\hline Total & 885 & 915 & 948 & 875 & 779 & 1484 \\
\hline
\end{tabular}

Fonte: Secretaria Municipal de Educação de São Bernardo do Campo 
Nas Tabelas II e III constata-se que o número de reprovações é maior nos anos em que ela pode ocorrer por aprendizagem insuficiente $\left(3^{\circ}\right.$ e $5^{\circ}$ anos $)$, porém chama a atenção o aumento do número de reprovações total, no ano de 2010, que quase dobrou, em relação ao ano anterior (2009), devido ao aumento, especialmente, no $3^{\circ}$ ano, sendo que o número total de reprovações vinha caindo desde 2007.

Sobre a avaliação, as unidades escolares eram orientadas a realizar bimestralmente os Conselhos de ano/ciclo, onde os professores se reuniam com seus pares e com a direção das escolas para discutirem o andamento das turmas, por meio de Relatórios Gerais da sala e da Ficha de Rendimentos de cada aluno. Os conceitos utilizados eram Satisfatório/Insatisfatório. Já para as turmas de educação infantil, as professoras eram orientadas a escrever Relatórios semestrais de cada aluno, ao invés da Ficha de Rendimentos utilizada no ensino fundamental.

Em 2009, o Índice de Desenvolvimento da Educação Básica (IDEB) ${ }^{10}$ do Município de São Bernardo do Campo foi 5,6. O município ultrapassou a meta para aquele ano que era de 5,3, tendo já alcançado naquele ano, a meta proposta para 2011.

\section{Caracterização da escola pesquisada}

De acordo com o PPP da escola pesquisada, a comunidade do entorno da escola foi constituida na década de 90, após grande enchente ocorrida numa área próxima. A comunidade era formada por famílias, com média de dois a três filhos, tinham baixa renda familiar - de um a três salários mínimos - além de condições de moradia insatisfatórias (terreno irregular e área de periculosidade). Devido às obras do Rodoanel, nos anos de 2007 a 2010, muitas famílias tiveram suas casas desapropriadas na área de construção e se mudaram para o bairro, aumentando assim sua comunidade.

O bairro contava com uma Escola Estadual (EE) que atendia o Ciclo II do ensino fundamental e o ensino médio, uma Escola Municipal de Iniciação Profissional (EMIP) e uma EMEB de educação infantil. Além disso, o bairro tinha um posto da Polícia Militar, uma Unidade Básica de Saúde (UBS), uma horta comunitária, uma padaria, supermercados, restaurantes, cabeleireiros, borracharias, farmácias, comércio de modo geral (bares e bazares), posto de gasolina e diversas igrejas - Igreja Católica, Igreja Evangélica, Candomblé. Havia

\footnotetext{
${ }^{10}$ Segundo o site do MEC: http://portal.mec.gov.br (acesso em: 14/05/2011), o Ideb foi criado em 2007 para medir a qualidade de cada escola e de cada rede de ensino. O indicador é calculado com base no desempenho do estudante em avaliações do INEP e em taxas de aprovação. O índice é medido a cada dois anos e o objetivo é que o país, a partir do alcance das metas municipais e estaduais, obtenha nota 6, em 2022.
} 
um projeto no bairro para construção de um Pronto Socorro, uma pista de skate, uma quadra de esportes, uma lotérica, um Centro de Referência ao Idoso (CRI), que faz parte do Sistema Único de Saúde (SUS), além de um Centro de Referência e Assistência Social (CRAS), que é uma unidade pública estatal.

A escola pesquisada inicou suas atividades em fevereiro de 2002, como escola provisória, onde funcionavam oito classes das séries iniciais do ensino fundamental. Com a conclusão da obra completa da escola, foi inaugarada em junho de 2003 e seu atendimento foi ampliado para 26 classes. Ela recebeu alunos de outra escola municipal próxima e de uma escola estadual, cujo alunos vieram para esta escola em função da municipalização do ensino em São Bernardo do Campo.

A escola possuía dois pavimentos: o primeiro, no piso térreo e o segundo, em andar acima, com acesso por escada e rampas apropriadas a alunos cadeirantes. No piso térreo, na área interna, havia uma cozinha com despensa e um refeitório, sala de direção, sala para vice direção, sala de coordenadores, almoxarifado, sala de professores, sala para reuniões pedagógicas, laboratório de informática, biblioteca interativa, ateliê de artes, secretaria, sala de recursos e apoio pedagógico, sala de inspetores, banheiro administrativo, banheiro para funcionários e banheiro para alunos (masculino e feminino), pátio interno, além de uma brinquedoteca, inaugarada em agosto de 2010, durante a pesquisa.

$\mathrm{Na}$ área externa havia um palco, quadra esportiva, área arborizada, pátio descoberto com bancos de concreto, banheiros para funcionários e comunidade, área de serviço, guarita, lixeiras recicláveis e área para estacionamento. O pátio contava com alguns brinquedos: balanços e gira-gira que se encontravam em mau estado de conservação.

No segundo pavimento havia banheiro para alunos, dezoito salas de aula, sendo três para educação infantil e treze para o ensino fundamental e sala de inspetores, onde ficava guardado o material de uso pedagógico da escola. Pela descrição pode-se afirmar que se tratava de uma escola com estrutura física bastante diversificada.

A escola funcionava em três períodos: manhã (das 7:00 ás 12:00), tarde (das 13:00 às 18:00) e noite (das 19:00 às 22:30) e contava com três modalidades de ensino: educação infantil, anos iniciais do ensino fundamental, dividido em dois ciclos, sendo o ciclo $\mathrm{I}$, do $1^{\mathrm{o}}$ ao $3^{\circ}$ anos e o ciclo II, do $4^{\circ}$ ao $5^{\circ}$ anos, e Educação de Jovens e Adultos (EJA) que atendia todo o ensino fundamental e possuia desde salas de alfabetização até as $7^{\mathrm{a}}$ e $8^{\mathrm{a}}$ séries do ensino fundamental. A escola atendia aproximadamente 1000 alunos, sendo 830 no período diurno e 160 nas salas de EJA e a média era de 25 alunos por sala, considerada ideal ou quase ideal por muitos pesquisadores e profissionais da educação. 
Trabalhavam na escola 47 professores, sendo 20 em regime de trabalho celetista, 24 estatutários e 3 conveniados. Destes, 26 professores tinham acúmulo de cargo na mesma escola, na mesma Prefeitura ou em outras escolas e Prefeituras.

Com relação à formação dos professores: 27 possuíam o diploma de Pedagogia, 8, o de Licenciatura de Letras, 2, o de Licenciatura de História, 2, o de Estudos Sociais, 2, o de Matemática, 2, o de Artes, um o de Ciências, um o de Educação Física, um o de Ciências Sociais, um o de Artes Cênicas, um o de Serviço Social, um o de Direito e um o de Normal Superior. Havia, ainda 2 professores sem Graduação de nível superior e 11 professores com diploma de Pós Graduação.

A escola contava ainda com 17 funcionários, constituindo a Equipe de Gestão, distribuídos entre oficiais administrativos, inspetores de alunos, equipe de apoio e uma estagiária de inclusão. Os funcionários tinham um Plano de Formação, com algumas reuniões quinzenais, onde estavam previstas, pelo menos, a participação de um funcionário terceirizado. O objetivo do estudo era conhecer o Estatuto da Criança e do Adolescente (ECA) e orientar seu uso na escola.

Sobre a formação da comunidade escolar, constavam no Projeto Político Pedagógico (PPP) da escola, os momentos de formação: as Reuniões Pedagógicas, os Conselhos de Ano/Ciclo e as Reuniões de Pais. Além disso, os professores tinham que participar do Horário de Trabalho Pedagógico Coletivo (HTPC) que ocorria em dois horários distintos: uma turma, às terças-feiras, à noite e, outra turma, nos sábados de manhã, sendo que os professores que tinham acúmulo de cargo na mesma escola deveriam participar das duas reuniões.

No PPP da escola constava, ainda, um Plano de Formação para os professores, que, de acordo com a diretora da escola (durante conversa informal, registrada no Caderno de Campo), foi elaborado por ela no início de 2010, baseado nas avaliações do ano anterior. Nele encontravam-se os seguintes objetivos para os planos de formação :

1) Resgatar com o grupo de professores o lúdico e incluí-lo de forma sistêmica e organizada em todos os espaços pedagógicos da Unidade Educacional, incluindo o recreio.

2) Elaborar com toda a equipe projetos que considerem o lúdico como elemento essencial para uma aprendizagem significativa.

3) Estudar a proposta curricular; ter acesso a legislação referente ao ensino fundamental de nove anos; elaborar objetivos e conteúdos para o $1^{\circ}$ ano do ensino fundamental de nove anos. (PPP escolar, 2010)

Além desses três planos de formação, constava no PPP que a escola deveria destinar dez reuniões de HTPC para estudo do Programa Ler e Escrever, que é um Programa 
elaborado pela SEE do Estado de São Paulo, realizado através de convênio com os municípios, que conta com um conjunto de linhas de ação articuladas que inclui formação, acompanhamento, elaboração e distribuição de materiais pedagógicos e outros subsídios, constituindo-se, dessa forma, como uma política pública para o Ciclo I, que buscava promover a melhoria do ensino em toda a rede estadual. Sua meta era ver plenamente alfabetizadas, até 2010 , todas as crianças com até oito anos de idade ( $2^{\mathrm{a}}$ série $/ 3^{\circ}$.ano), bem como garantir recuperação da aprendizagem de leitura e escrita aos alunos das demais séries/anos do Ciclo I do ensino fundamental.

A avaliação ocorria bimestralmente, por meio dos Conselhos de Classe, citados anteriormente. A escola contava com um programa de recuperação paralela, chamado "Apoio Pedagógico", que ocorria em horário contrário às aulas, sendo normalmente priorizados nesse atendimento, os alunos que estudavam nos anos finais dos ciclos e que apresentavam rendimento insatisfatório.

A escola possuía Associação de Pais e Mestres (APM), criada em outubro de 2003, cujo Plano de Ação era realizar reuniões formativas, garantir a divulgação das ações e a participação nos eventos da escola. O Conselho de Escola (CE), criado em março de 2004, tinha como Plano de Ação, a leitura e discussão do ECA, a participação nos Conselhos de ano/ ciclo e a realização de atividades conjuntas com a APM.

$\mathrm{Na}$ escola ocorriam ainda aulas de balé e judô, sob responsabilidade de instituições particulares e eram pagas, onde o papel da escola e da Secretaria de Educação era, apenas, o de ceder o espaço para essas atividades extracurriculares. A escola participava do Programa de Saúde Bucal, que era gratuito e destinado a todas as crianças da escola, onde dentistas iam até lá para distribuir escovas de dente e creme dental, além de dar palestras para os alunos sobre como escovar os dentes e a importância do cuidado com os dentes.

No segundo semestre de 2010, teve início na escola, o Programa "Tempo de Escola". Este era um projeto da Secretaria Municipal de Educação destinado a crianças em situação de risco, que eram indicadas pelas professoras de suas salas, de acordo com a inscrição dos pais (SÃO BERNARDO DO CAMPO, 2011a). Oficialmente, o Programa não explicava o que caracterizava uma criança em situação de risco, tendo as professoras explicitado que indicavam as crianças que tinham famílias muito carentes ou que eram muito indisciplinadas e que, por isso, acreditavam que tinham algum problema em casa. Isso demonstra o caráter assistencialista do Programa e a falta de informações dadas às professoras para a escolha dessas crianças. 
Essas crianças participavam de oficinas, duas vezes por semana, em horário inverso ao das aulas. Eram diversas oficinas oferecidas, tais como: oficinas de arte cênica, visual e musical, modalidades esportivas, dança e brincadeiras infantis, além do aprendizado de confecção de brinquedos. A Prefeitura disponibilizava transporte aos alunos, pois no caso da escola pesquisada, as oficinas eram realizadas em um parque, próximo à escola. As crianças recebiam, ainda, um uniforme do Programa que contava com educadores selecionados, que haviam passado por treinamentos especiais. De acordo com a Secretária de Educação: "Essa será uma das maneiras de ampliar o universo cultural e construir conhecimento dessas crianças." (Secretária de educação de São Bernardo do Campo, 2011)

Os objetivos da escola, segundo o Projeto Político Pedagógico (PPP) da mesma, eram:

“a) atuar no processo de construção da cidadania, mediante a inclusão de todos, respeitando as semelhanças e diferenças, na busca de uma escola de qualidade incluída, de fato, no contexto social em que ela se encontra;

b) garantir a cosntrução do princípio da inclusão;

c) garantir condições para que o aluno adquira competências por meio da interação dos conhecimentos prévios, dos diferentes conteúdos aprendidos na escola, que o capacitem para um processo de formação aplicado à sua realidade.

(...)

- garantir acesso e permanência de todos os alunos

- garantir condições para que o aluno construa instrumentos por meio das áreas de conhecimento e diferentes conteúdos desenvolvidos na escola, que o capacitem para um processo de formação aplicável a sua realidade.

- Desenvolver no aluno habilidades que o tornem capaz de "aprender a aprender", "aprender a fazer", e "aprender a ser", tendo como meios básicos o domínio da leitura, escrita e do cálculo, bem como a formação de atitudes e valores. Sensibilizar o aluno para compreensão do ambiente natural e social, e dos valores em que se fundamenta a sociedade, percebendo-se como integrante e agente transformador.. (PPP escolar, 2010)

É importante destacar que a escola pesquisada, no mês de abril, já contava com o PPP atualizado para o ano de 2010, com as modificações referentes à ampliação do ensino fundamental para nove anos, fato este, inédito na maioria das escolas públicas da cidade e da região. 


\section{Reflexões sobre o ensino fundamental de nove anos e direito à educação}

Vocês acham que crianças de 6 anos devem ir para a escola? Crianças (em coro) - Sim. Por quê? Porque se elas não forem para escola quando elas crescerem vão ficar sem aprender; elas têm que aprender e passar de ano, para aprender a ler e a escrever, também para ficar esperto na escola, para aprender a fazer as coisas direito, e também para ficar com a cabeça bem grandona. (Crianças5, 7, 8 e 9)

Neste capítulo pretende-se fazer uma breve descrição histórica sobre o ensino fundamental enquanto direito à educação no Brasil. A seguir, será analisado se a "ampliação do direito à educação" foi tema explicitado nas propostas de ampliação do ensino fundamental para nove anos, e se, com a entrada das crianças de seis anos no ensino fundamental, houve aumento no atendimento das crianças de zero a cinco anos na educação infantil. Ainda, se as matrículas mantiveram-se estáveis, além de verificar se os novos alunos no $1^{\circ}$ ano estavam fora da escola ou se já frequentavam a educação infantil. Por último, será descrita e analisada a opinião das crianças e dos pais sobre a obrigatoriedade das crianças de seis anos frequentarem a escola e se prefeririam estudar na educação infantil ou no ensino fundamental.

\subsection{O direito à educação no Brasil e o ensino fundamental de nove anos}

Atualmente, o direito à educação é reconhecido como um dos direitos fundamentais das pessoas e está inserido na legislação de praticamente todos os países ocidentais. Ele consiste na compulsoriedade e na gratuidade da educação, podendo variar nos sistemas legais dos diversos países, com relação ao número de anos e/ou níveis de escolaridade previstos a todos os cidadãos.

No Brasil pós independência (1822), a primeira Constituição que colocou a instrução primária como gratuita a todos os cidadãos foi a Constituição Imperial, de 1824, porém o Poder Público da época pouco fez para garantir esse direito. Além disso, grande parte da população era formada por escravos que não eram considerados cidadãos, não tendo, portanto direitos sociais, dentre eles, o da educação.

A Proclamação da República ocorreu em 1889 e, em 1891, foi escrita e aprovada a primeira Constituição Republicana. Nessa Constituição, porém, houve a derrota das emendas que propuseram o ensino obrigatório e gratuito no texto. 
Após a Revolução de 1930, a Constituição de 1934 dedicou, pela primeira vez, um capítulo à educação e com relação à declaração do direito à educação, estabeleceu, no Art. 149 que:

\begin{abstract}
A educação é direito de todos e deve ser ministrada pela família e pelos Poderes Públicos, cumprindo a estes proporcioná-la a brasileiros e a estrangeiros domiciliados no País, de modo que possibilite eficientes fatores de vida moral e econômica da Nação, e desenvolva num espírito brasileiro a consciência da solidariedade humana. (BRASIL, 1934)
\end{abstract}

Além de estabelecer a educação como direito de todos, no Art. 150, explicitou a extensão desse direito como: “a) ensino primário integral gratuito e de frequência obrigatória extensivo aos adultos. b) tendência à gratuidade do ensino educativo ulterior ao primário, a fim de o tornar mais acessível."

A Constituição de 1937, decorrente do golpe de Estado, em 10 de novembro do mesmo ano, e decretada por Getúlio Vargas, então ditador, foi um retrocesso para o direito à educação, pois além de colocar a educação na parte relativa à família e não o mencionar como dever do Estado, estabelecia a gratuidade do ensino somente para os pobres. O Art. 130 dispunha que:

O ensino primário é obrigatório e gratuito. A gratuidade, porém, não exclui o dever de solidariedade dos menos para com os mais necessitados; assim, por ocasião da matrícula, será exigida aos que não alegarem, ou notoriamente não puderem alegar escassez de recursos, uma contribuição módica e mensal para a caixa escolar." ( BRASIL, 1937)

Já a Constituição de 1946, em momento de redemocratização no país, retomou a idéia da educação como direito de todos, dispondo no Art. 166: “A educação é direito de todos e será dada no lar e na escola. Deve inspirar-se nos princípios de liberdade e nos ideais de solidariedade humana". (BRASIL, 1946) Além disso, o Art. 168 estabeleceu, novamente, a gratuidade do ensino primário:

\begin{abstract}
A legislação do ensino adotará os seguintes princípios: I - o ensino primário é obrigatório e só será dado na língua nacional; II - o ensino primário oficial é gratuito para todos; o ensino oficial ulterior ao primário sê-lo-á para quantos provarem falta ou insuficiência de recursos. (BRASIL, 1946)
\end{abstract}

Na Constituição de 1967 e na Emenda Constitucional nº 1, de 1969, durante a Ditadura Militar, iniciada em 1964, e que durou até 1985, o período de escolarização obrigatória foi ampliado para oito anos, mantendo-se a denominação "ensino primário" e na 
Emenda de 1969, no Art. 176 foi reconhecida, pela primeira vez, a educação como "Direito de todos e dever do Estado". (BRASIL, 1967, 1969)

Com a retomada da democracia, em 1985, foi elaborada, por processo constituinte, uma nova Constituição, promulgada em 1988, e em vigência até hoje. No capítulo da Educação, no Art. 205, está definido que: “A educação, direito de todos e dever do Estado e da família, será promovida e incentivada com a colaboração da sociedade, visando ao pleno desenvolvimento da pessoa, seu preparo para o exercício da cidadania e sua qualificação para o trabalho.", reafirmando o dever do Estado com a educação. E, no Art. 206, inciso IV está estabelecida a: "gratuidade do ensino público nos estabelecimentos oficiais", garantindo-se a gratuidade para todos os níveis e modalidades de ensino. (BRASIL, 1988)

Além disso, o direito à educação foi especificado no Art. 208, por meio das seguintes garantias:

O dever do Estado com a educação será efetivado mediante a garantia de:

I - ensino fundamental, obrigatório e gratuito assegurado, inclusive sua oferta gratuita para todos os que a ele não tiveram acesso na idade própria;

II - progressiva extensão da obrigatoriedade e gratuidade ao ensino médio;

III - atendimento educacional especializado aos portadores de deficiência, preferencialmente na rede regular de ensino;

IV - atendimento em creche e pré-escola às crianças de zero a cinco anos de idade;

$\mathrm{V}$ - acesso aos níveis mais elevados do ensino, da pesquisa e da criação artística, segundo a capacidade de cada um;

VI - oferta de ensino noturno regular, adequado às condições do educando;

VII - atendimento ao educando, no ensino fundamental, através de programas suplementares de material didático-escolar, transporte, alimentação e assistência à saúde.

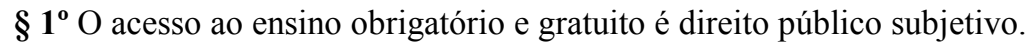

$\$ \mathbf{2}^{\mathbf{0}} \mathrm{O}$ não-oferecimento do ensino obrigatório pelo poder público, ou sua oferta irregular, importa responsabilidade da autoridade competente.

$\S \mathbf{3}^{\mathbf{0}}$ Compete ao poder público recensear os educandos no ensino fundamental, fazer-lhes a chamada e zelar, junto aos pais ou responsáveis, pela freqüência à escola. (idem)

É importante citar que a educação infantil não havia sido mencionada em nenhuma Constituição anterior como integrante do direito à educação, aparecendo pela primeira vez na Constituição de 1988. E o ensino fundamental aparece definido como "direito público subjetivo", podendo todos os cidadãos reivindicá-lo, perante o Poder Público, pois, constituído como direito público subjetivo, o ensino fundamental deveria ser oferecido a todo o "universo escolarizável", como afirma CURY (2007, grifo do autor). De modo que, qualquer pessoa, de qualquer idade, que tenha tido ou não acesso à escola na faixa etária ideal, pode lançar mão dessa prerrogativa legal, cuja responsabilidade está submetida ao Estado e, portanto, é dele o dever de garantir o direito à educação. 
O Estatuto da Criança e do Adolescente (ECA), Lei nº 8069/1990, no Capítulo IV,

Art. 53, também se refere ao direito à educação nos seguintes termos:

A criança e o adolescente têm direito à educação, visando ao pleno desenvolvimento de sua pessoa, preparo para o exercício da cidadania e qualificação para o trabalho, assegurando-se-lhes:

I - igualdade de condições para o acesso e permanência na escola;

II - direito de ser respeitado por seus educadores;

III - direito de contestar critérios avaliativos, podendo recorrer às instâncias escolares superiores;

IV - direito de organização e participação em entidades estudantis;

$\mathrm{V}$ - acesso à escola pública e gratuita próxima de sua residência.

Parágrafo único. É direito dos pais ou responsáveis ter ciência do processo pedagógico, bem como participar da definição das propostas educacionais. (BRASIl, 1990)

Por fim, a Lei de Diretrizes e Bases da Educação (LDB), 1996, detalhou o direito à educação e o dever do Estado, em seu Título III, Art. $4^{\circ}$, ampliando os termos dos incisos do Art. 204, da Constituição de 1988:

O dever do Estado com educação escolar pública será efetivado mediante a garantia de:

I - ensino fundamental, obrigatório e gratuito, inclusive para os que a ele não tiveram acesso na idade própria;

II - progressiva extensão da obrigatoriedade e gratuidade ao ensino médio; ${ }^{11}$

III - atendimento educacional especializado gratuito aos educandos com necessidades especiais, preferencialmente na rede regular de ensino;

IV - atendimento gratuito em creches e pré-escolas às crianças de zero a seis anos de idade;

V - acesso aos níveis mais elevados do ensino, da pesquisa e da criação artística, segundo a capacidade de cada um;

VI - oferta de ensino noturno regular, adequado às condições do educando;

VII - oferta de educação escolar regular para jovens e adultos, com características e modalidades adequadas às suas necessidades e disponibilidades, garantindo-se aos que forem trabalhadores as condições de acesso e permanência na escola;

VIII - atendimento ao educando, no ensino fundamental público, por meio de programas suplementares de material didático-escolar, transporte, alimentação e assistência à saúde;

IX - padrões mínimos de qualidade de ensino, definidos como a variedade e quantidade mínimas, por aluno, de insumos indispensáveis ao desenvolvimento do processo de ensino-aprendizagem.

$\mathrm{X}$ - vaga na escola pública de educação infantil ou de ensino fundamental mais próxima de sua residência a toda criança a partir do dia em que completar 4 (quatro) anos de idade. (BRASIL, 1996b) ${ }^{12}$

Nesse artigo há dois acréscimos importantes: o inciso VII, que trata da educação de jovens e adultos e o inciso IX, que detalha o inciso VII do Art. 206, da Constituição Feferal

\footnotetext{
${ }^{11}$ Este inciso foi substituído por: II - universalização do ensino médio gratuito; (Redação dada pela Lei ${ }^{\circ}$ 12.061, de 2009).
}

${ }^{12} \mathrm{O}$ inciso X foi incluído, em 2008, pela Lei $\mathrm{n}^{\mathrm{o}} 11.700$. 
de 1988 (CF/88), relacionando os padrões mínimos de qualidade com um gasto mínimo por aluno e, que, de acordo com Romualdo Portela de Oliveira: "segundo a interpretação oficial atual, seria operacionalizada pelo Fundo de Manutenção e Desenvolvimento do Ensino Fundamental e de Valorização do Magistério (FUNDEF).” (OLIVEIRA, 2001, p. 39), que caracterizou a Política de Fundos adotada na época.

Dado que a educação deve ser acessível a todos por meio da responsabilidade insubstituível do Estado e que devem ser mantidos padrões mínimos de qualidade, associados a um gasto mínimo por aluno, não é possível garantir a gratuidade e obrigatoriedade do atendimento sem os recursos financeiros necessários. Nessa perspectiva, a legislação também garantiu uma estrutura de financiamento da educação, baseada na vinculação constitucional de recursos, nos termos da $\mathrm{CF} / 88$, de $18 \%$ e $25 \%$, respectivamente para o Governo Federal e para os Governos Estaduais e Municipais, de modo a responsabilizar as esferas públicas pelo provimento do mínimo de recursos necessários à manutenção e desenvolvimento do ensino.

Dessa forma, no mesmo ano da aprovação da LDB foi instituído um Fundo (pela Emenda Constitucional $n^{\circ} 14$ de 1996, e regulamentado pela Lei $n^{\circ}$ 9.424/96) com o objetivo de garantir o financiamento da educação fundamental no Brasil, que previa um percentual vinculatório de $15 \%$, dos $25 \%$ constitucionalmente vinculados, em relação aos principais impostos arrecadados nas duas esferas administrativas. Esse Fundo, recebeu o nome de Fundo de Manutenção e Desenvolvimento do Ensino Fundamental e Valorização do Magistério (FUNDEF), com vigência definida de 1997 a 2006, criava Fundos estaduais e estabelecia repasses de recursos aos Estados e Municípios, de acordo com o número de matrículas de alunos atendidos, de maneira que quanto maior fosse o número de matrículas nesta etapa de ensino, maior o quantum de recursos financeiros repassados.

Com isto, criou-se um movimento de transferência da responsabilidade por essa etapa de ensino para os Municípios, pois dados oficiais demonstraram que no período de vigência do FUNDEF, as matrículas no ensino fundamental na rede municipal cresceram muito mais, se comparadas às das redes estaduais, como afirmaram Arelaro, Jacomini e Klein (2011):

É necessário atentar para o fato de que o processo de municipalização do ensino fundamental, considerado o ano de 2006, já havia provocado um aumento significativo das matrículas nas redes municipais de ensino, uma vez que $60 \%$ dos atendimentos públicos nessa etapa estavam municipalizados e, do total das matrículas de $1^{\mathrm{a}}$ a $4^{\mathrm{a}}$ séire, $75 \%$ delas já estavam sob responsabilidade municipal, e somente $25 \%$ sob a estadual. (ARELARO;JACOMINI; KLEIN, 2011, p. 39). 
A municipalização guarda relação com a orientação constitucional que determina, no Art. 211, que a União, os Estados, o Distrito Federal e os Municípios devem organizar seus sistemas em regime de colaboração, mas afirma no $\S 2^{\circ}$, que os Municípios devem se responsabilizar prioritariamente pela educação infantil e pelo ensino fundamental e, no $\S 3^{\circ}$, do mesmo artigo, que o Distrito Federal e os Estados devem se responsabilizar prioritariamente pelo ensino fundamental e médio. Esse movimento está cada vez mais consolidado, de maneira que os Municípios praticamente incorporaram o ensino fundamental às suas redes, como no caso de São Bernardo do Campo, que municipalizou o atendimento dos primeiros anos do ensino fundamental, a partir de 1999, como visto anteriormente.

Além disso, com a implementação do FUNDEF, os municípios mais pobres poderiam, em alguns casos, receberem mais verbas do governo federal, de acordo com o número de matrículas que tivessem nessa etapa de ensino, motivando que se iniciasse um processo de antecipação da idade de entrada das crianças nessa etapa de ensino, agora com seis anos.

A LDB/nº 9394/96, no artigo 87, das Disposições Transitórias, já permitia a matrícula das crianças com seis anos de idade no ensino fundamental, desde que atendida a demandas das crianças de sete anos, porém, é importante destacar, que a matrícula das crianças com seis anos ainda não estava vinculada a ampliação do ensino fundamental para nove anos, como se pode verificar: "Parágrafo $3^{\circ}$ - Cada município e, supletivamente o Estado e a União, deverá: I- matricular todos os educandos a partir dos sete anos de idade, e fcultativamente, a partir dos seis anos, no ensino fundamental." (BRASIL, 1996b)

Com isso, se a cada aluno matriculado a rede de ensino recebesse uma quantia maior de dinheiro, pode-se dizer que surgiu, por parte dos municípios, um interesse maior em cumprir o disposto no mencionado Art 87, da LDB, aumentando o número de matrículas das crianças com menos de sete anos no ensino fundamental.

A esse respeito, Guimarães e Pinto (2001) destacaram que:

\begin{abstract}
Assim, de 1997 para 1998, enquanto a rede estadual apresentou uma queda de 4,4\% nas matrículas nesse nível de ensino [Ensino Fundamental], os municípios tiveram um crescimento de $21,8 \%$, resultando num crescimento médio de $6,2 \%$ nas matrículas da rede pública, índice bem acima da média anual da década anterior. Esse salto pode ser explicado pela incorporação das antigas classes de alfabetização, com forte presença no Nordeste e Rio de Janeiro, no ensino fundamental, assim como das crianças de 6 anos, incentivando-se o seu ingresso precoce neste nível de ensino. (GUIMARÃES; PINTO, 2001 p. 99)
\end{abstract}

No Brasil pode-se destacar duas vertentes teóricas sobre a nova organização do ensino fundamental: a primeira, defendida nos documentos oficiais do Ministério da Educação, que 
afirmava que esta política teria um caráter democratizador ao estender a oferta obrigatória do ensino fundamental às crianças de seis anos. E a segunda, defendida por alguns teóricos, que apontavam para a redução da duração da educação infantil como redução dos direitos dessa mesma etapa de ensino. Argumentavam que o Governo poderia ter optado por tornar obrigatória a matrícula na educação infantil e ampliado os recursos financeiros e técnicos nessa etapa de ensino, não prejudicando o direito das crianças de seis anos, que "perdendo" um ano na educação infantil não estariam tendo seu direito à qualidade de ensino, já que o ensino fundamental não estaria organizado de forma adequada às suas necessidas.

Com relação aos documentos oficiais do MEC, o documento "Ensino Fundamental de nove anos: orientações gerais" ( BRASIL, 2004a) justificou a importância da ampliação do ensino fundamental, com início aos seis anos de idade, como uma ampliação do direito à educação. Nele, havia um capítulo explicando o porquê da escolha dos seis aos catorze anos e não dos sete aos quinze anos de idade:

Conforme recentes pesquisas, $81,7 \%$ das crianças de seis anos estão na escola, sendo que 38,9\% freqüentam a Educação Infantil, 13,6\% as classes de alfabetização e 29,6\% já estão no Ensino Fundamental (IBGE, Censo Demográfico 2000). Esse dado reforça o propósito de ampliação do Ensino Fundamental para nove anos, uma vez que permite aumentar o número de crianças incluídas no sistema educacional. Os setores populares deverão ser os mais beneficiados, uma vez que as crianças de seis anos da classe média e alta já se encontram majoritariamente incorporadas ao sistema de ensino - na pré-escola ou na primeira série do Ensino Fundamental. A opção pela faixa etária dos 6 aos 14 e não dos 7 aos 15 anos para o Ensino Fundamental de nove anos segue a tendência das famílias e dos sistemas de ensino de inserir progressivamente as crianças de 6 anos na rede escolar. (BRASIL, 2004a, p. 17)

O Governo Federal ponderou nesse momento que, as crianças de seis anos, das classes média e alta já estavam matriculadas em escolas e que seria necessário incluir as classes mais desfavorecidas. A consideração de que as crianças de seis anos ainda estavam fora da escola, seja pelo fato da não obrigatoriedade da educação infantil, ou pela inexistência de oferta de vagas suficientes na educação infantil pública, gerou um alegado consenso de que o ensino fundamental de nove anos garantiria um maior número de alunos matriculados nas escolas brasileiras e, portanto, asseguraria a essas crianças a extensão e efetivação do seu direito à educação.

Além disso, se a maioria das crianças de seis anos $(38,9 \%)$ estava matriculada em escolas de educação infantil, por que não tornar obrigatória a matrícula nessa etapa de ensino? Klein (2011), traz dados sobre a progressão dos dados de matrícula das crianças de seis anos na década de 1990 e a mudança da matrícula da educação infantil para o ensino fundamental: 


\begin{abstract}
Se compararmos os dados apresentados pelo CNE, no Parecer CNE/ CEB n ${ }^{\circ}$. 20/98, com os dados apresentados pelo MEC, no documento "Orientações Gerais" de 2004, pode-se afirmar que o percentual de matrículas de crianças de seis anos escolarizadas sobe de $74 \%$ para $82 \%$, das quais $16 \%$ mantêm-se em Classes deAlfabetização (nos dois períodos). A diferença entre o lócus de atendimento pode reforçar a argumentação sobre a indução das matrículas no EF a partir do FUNDEF, tendo em vista que, em 1996, 64\% das crianças estavam na EI e $20 \%$ no EF, e em 2000, 48\% estava na EI e 36\% no EF. (KLEIN, 2011, p. 74-75)
\end{abstract}

Em função disso, pode-se afirmar que, conforme visto anteriormente, o FUNDEF foi indutor da matrícula das crianças de seis anos no ensino fundamental que, com isso, acabaram por perder um ano de escolarização, pois sairam mais cedo da educação infantil, entrando no ensino fundamental antes dele ter sido ampliado para nove anos, tendo seu direito à educação prejudicado, pelo menos neste período.

Outro documento que justificou a ampliação do ensino fundamental para nove anos como uma ampliação do direito à educação, foi o documento "Orientações para a inclusão das crianças de seis anos" (BRASIL, 2006d). Nele, Anelise Monteiro do Nascimento afirmou em seu texto: A infância na escola e na vida: uma relação fundamental, que:

[...] podemos ver o ensino fundamental de nove anos como mais uma estratégia de democratização e acesso à escola. A Lei $n^{\circ} 11.274$, de 6 de fevereiro de 2006, assegura o direito das crianças de seis anos à educação formal, obrigando as famílias a matriculá-las e o Estado a oferecer o atendimento. (BRASIL, 2006d, p. 27)

No mesmo documento, Patricia Corsino, no texto: As crianças de seis anos e as áreas de conhecimento, reafirmou esta ideia, ao apresentar o ensino fundamental de nove anos, como uma oportunidade histórica para as crianças de seis anos das classes populares frequentarem a escola:

[...] a ampliação do ensino fundamental para nove anos, que significa bem mais que a garantia de mais um ano de escolaridade obrigatória, é uma oportunidade histórica de a criança de seis anos pertencente às classes populares ser introduzida a conhecimentos que foram fruto de um processo sócio-histórico de construção coletiva. (BRASIL, 2006d, p. 61-62)

Porém, sobre a justificativa da ampliação do ensino fundamental para nove anos como ampliação do direito à educação, Arelaro, Jacomini e Klein, no artigo "O ensino fundamental de nove anos e o direito à educação" afirmaram que: 
Esssa argumentação parte de pressupostos nem sempre condizentes com a legislação vigente. O primeiro deles é que a criança de seis anos não teria assegurado seu direito à educação, uma vez que se encontra na etapa não obrigatória da educação infantil. De acordo com a CF/88, art. 208, é dever do Estado e direito das crianças e das famílias a matrícula na educação infantil (em creches e pré-escolas). Portanto, nos termos da Lei, o direito das crianças à educação formal, desde seu nascimento, está garantido. Se o governo reconhece que as instituições de educação infantil não ofertam vagas suficientes para atender a estas crianças, a consequência lógica seria o estímulo técnico-financeiro para que os municípios assumissem sua responsabilidade constitucional. No entanto, a opção foi por uma política nacional de novo lócus de estudo dessa criança, uma transferência de etapa de ensino que significou mudança em diversos aspectos no atendimento. (ARELARO, JACOMINI, KLEIN, 2011, p. 38,)

É importante ressaltar, ainda, que, se o FUNDEF significou um aumento nas matrículas das crianças de seis anos no ensino fundamental, ao mesmo tempo, gerou uma diminuição do investimento na educação infantil e, assim, no número de matrículas nessa etapa de ensino:

Nos anos 1990, a aprovação do Fundo de Manutenção e Desenvolvimento do Ensino Fundamental e de Valorização do Magistério (FUNDEF) foi uma evidência da centralidade ocupada pelo EF em nossas políticas públicas, uma vez que os recursos desse fundo se destinavam exclusivamente a esse nível de ensino. Em muito municípios nos quais a matrícula na EI vinha crescendo, o processo foi interrompido, havendo uma estagnação e, em alguns casos, diminuição da oferta. (CORREA, 2011, p. 107)

Sendo assim, esta antecipação da idade de ingresso das crianças, poderia indicar uma opção das autoridades educacionais, em priorizar o investimento no ensino fundamental, ao invés de fazê-lo na universalização do atendimento a essa faixa etária na educação infantil, processo que demandaria maior esforço administrativo. A formulação da Lei não possibilitou sequer que os municípios optassem por matricular as crianças de seis anos na educação infantil, caso a rede já comportasse o atendimento dessa faixa etária nessas escolas, ou que os pais pudessem escolher manter seus filhos mais um ano na educação infantil.

\section{2. $O$ ensino fundamental de nove anos e o direito à educação no município de São Bernardo do Campo}

Por que vocês acham que as crianças devem ir para escola? Porque é para ensinar, para aprender, para não falar palavrão, porque na escola tem que ter educação e aprender várias coisas.(Crianças 1, 2 e 3) 
Com relação à legislação do Município, foram encontrados os seguintes Pareceres e Deliberações do Conselho Municipal de Educação (CMED) sobre a ampliação do ensino fundamental para nove anos.

A Deliberação CMED n $n^{0}$ 03/07, que dispunha sobre a transferência de alunos de outros Sistemas de Ensino para o Sistema Municipal de ensino fundamental de São Bernardo do Campo, afirmava que

Quando a transferência de alunos entre escolas com cursos de Ensino Fundamental for organizada sob critérios diferentes da Rede Municipal de Ensino, far-se-á baseada na aplicação da correspondência existente entre a idade do aluno e o ano/ciclo cursado ou ano/ciclo a ser cursado." (SÃO BERNARDO DO CAMPO, 2007)

A Deliberação CMED nº 4/2009 dispunha sobre a implantação do ensino fundamental de nove anos de duração no Sistema Municipal de Ensino. Essa Deliberação afirmava que o ensino fundamental de nove anos seria implantado a partir de 2010 na rede municipal de ensino. Com relação à matrícula, a Deliberação estabelecia que o acesso ao ensino fundamental de 9 (nove) anos deveria ser efetivado a partir dos 6 (seis) anos de idade, completados até o dia 28 de fevereiro do ano de ingresso (ou 29 de fevereiro, quando fosse o caso) e que, apenas em 2010, poderia haver matrícula de crianças que completassem 7 (sete) anos até o dia 30 de junho de 2010, no $1^{\circ}$ ano do ensino fundamental de 8 (oito) anos de duração, ou seja, apenas nesse período de transição. Sobre a educação infantil, a Deliberação afirmava que ela teria 5 (cinco) anos de duração. Em anexo à Deliberação encontravam-se os seguintes quadros sobre a matrícula:

\section{Quadro I}

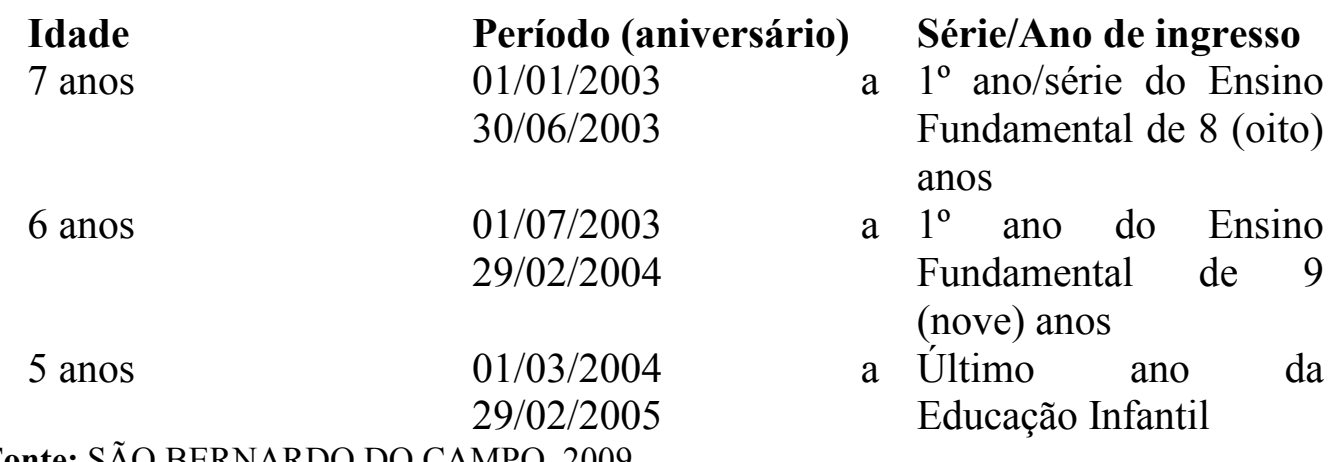

\section{Quadro II}

\begin{tabular}{|l|l|l|l|}
\hline & $\begin{array}{l}\text { Ensino Fundamental } \\
\text { de 8 anos }\end{array}$ & $\begin{array}{l}\text { Ensino Fundamental } \\
\text { de 9 anos }\end{array}$ & $\begin{array}{l}\text { Idade referência } \\
\text { Quadro I }\end{array}$ \\
\hline Pré-Escola & $1^{\mathrm{a}}$ fase & $1^{\mathrm{a}}$ fase & 4 anos \\
\cline { 2 - 5 } & $2^{\mathrm{a}}$ fase & $2^{\mathrm{a}}$ fase & 5 anos \\
\hline
\end{tabular}




\begin{tabular}{|c|c|c|c|}
\hline Pré-Escola/EF & $3^{a}$ fase & $1^{\circ}$ ano & 6 anos \\
\hline \multirow{4}{*}{ Anos Iniciais } & $1^{\circ}$ ano/série & $2^{\circ}$ ano & 7 anos \\
\hline & $2^{\circ}$ ano/série & $3^{\circ}$ ano & 8 anos \\
\hline & $3^{\circ}$ ano/série & $4^{\circ}$ ano & 9 anos \\
\hline & $4^{\circ}$ ano/série & $5^{\circ}$ ano & 10 anos \\
\hline \multirow{4}{*}{ Anos Finais } & $5^{\circ}$ ano/série & $6^{\circ}$ ano & 11 anos \\
\hline & $6^{\circ}$ ano/série & $7^{\circ}$ ano & 12 anos \\
\hline & $7^{\circ}$ ano/série & $8^{\circ}$ ano & 13 anos \\
\hline & $8^{\circ}$ ano/série & $9^{\circ}$ ano & 14 anos \\
\hline
\end{tabular}

Fonte: SÃO BERNARDO DO CAMPO, 2009.

O Parecer CME $n^{\circ} 13 / 2010$, que aprovou os critérios relativos ao ingresso no primeiro ano do ensino fundamental, definiu que a matrícula no primeiro ano do ensino fundamental de nove anos fosse de crianças que tivessem 6 (seis) anos completos até o dia 31 de março do ano em que tivesse ocorrido a matrícula. Não admitia, portanto, matrícula de crianças no ensino fundamental que completassem 6 (seis) anos após a data citada, devendo as mesmas ser matriculadas na educação infantil. O Parecer previa, também, que não se admitiria que, em 2011, fosse dado prosseguimento para o ensino fundamental de 9 (nove) anos às crianças de 5 (cinco) anos de idade que em seu percurso educacional tiveram estado matriculadas e tivessem frequentado, até o final de 2010, por 2 (dois) anos a pré-escola, não regulamentando a excepcionalidade prevista no $\S 2^{\circ}$, do art. $5^{\circ}$, da Resolução CNE/CEB n ${ }^{\circ} 6$, de 20 de outubro de 2010, que havia definido que:

$\S 2^{\circ}$ - Os sistemas de ensino poderão, em caráter excepcional, no ano de 2011, dar prosseguimento para o Ensino Fundamental de 9 (nove) anos às crianças de 5 (cinco) anos de idade, independentemente do mês do seu aniversário de 6 (seis) anos, que no seu percurso educacional estiveram matriculadas e frequentaram, até o final de 2010, por 2 (dois) anos ou mais a Pré-Escola. (BRASIL, 2010b)

De acordo com a Secretária de Educação, o Governo Municipal optou que algumas crianças de seis anos fossem atendidas nas escolas de educação infantil, em turmas já com o nome de $1^{\circ}$ ano, pois não havia espaço em todas as escolas de ensino fundamental para receber as crianças. Segundo ela:

Neste caso, do primeiro ano do ciclo de nove anos, algumas escolas não tinham espaço e, portanto, as crianças ficaram na pré-escola, mas já com o nome de primeiro ano do fundamental de nove anos e vamos conviver ao longo dos oito anos com as duas formas: fundamental de oito e de nove anos, porque como começamos em 2010, só terminará em 2018. Não 2018 porque aqui é só do primeiro ao quinto ano, porque aqui é por ciclos, então vamos conviver por cinco anos até que todos estejam no fundamental de nove anos, enquanto Santo André todos já estão no fundamental de nove anos. (Secretária da Educação de São Bernardo do Campo, 2011). 
$\mathrm{Na}$ escola pesquisada, com relação à data de corte de idade para a formação das salas, como a escola já contava com duas salas do último ano de educação infantil, denominado Infantil $\mathrm{V}$, eles optaram por abrir para o ano de 2010 , quatro salas de $1^{\circ}$ ano do EF9 ${ }^{13}$ com as crianças de seis anos ou que completariam seis até o dia 31 de março de 2010, data de corte estabelecida pelo Governo Federal e pela Prefeitura Municipal de São Bernardo do Campo, e quatro salas de $1^{\circ}$ ano do EF8, com as crianças que já haviam completado sete anos ou que completariam até o dia 31 de março de 2010. As demais crianças que não completassem seis anos até o dia 31 de março ficariam mais um ano no Infantil V. As salas foram divididas entre o período da manhã e da tarde, sendo duas do $1^{\circ} \mathrm{EF} 8$ e duas do $1^{\circ} \mathrm{EF} 9$, no período da manhã e as outras duas de cada turma, no período da tarde.

A diretora explicou em entrevista que, na organização anterior, todas as crianças que estivessem no Infantil $\mathrm{V}$ iriam para o $1^{\circ}$ ano EF8, pois a data de corte utilizada era o "ano cheio", ou seja, a criança poderia fazer sete anos até o final do ano, sendo assim as que estavam matriculadas no Infantil V eram as que fariam seis anos até o final de 2009. Com a nova organização, a data de corte mudou para o final de março, então as crianças que antes estudavam juntas foram separadas entre o $1^{\circ}$ ano EF8 e o $1^{\circ}$ ano EF9, o que gerou confusão para alguns pais, como explicou a diretora da escola:

\begin{abstract}
(...)a maioria que estava aqui comigo iam todos para a primeira série porque já tinha sala de cinco. Se não houvesse a data de corte eles iriam para a primeira. Lá no (cita nome de uma escola de educação infantil da região) que é uma escola que tem educação infantil e creche funcionava o infantil de quatro anos. Alguns alunos de lá vieram para cá, para o fundamental de nove pela idade de corte e todos os meus ficaram divididos por causa da lei, mas os outros que nunca foram a escola vieram para cá. Fiquei com os meus e dos meus tive que dividir e deu um nó na cabeça de muitos pais porque antes trabalhávamos com ano cheio. Vamos supor: Uma criança de cinco anos, entrava na sala de cinco anos com ano cheio, mesmo que ela fizesse cinco anos em dezembro, no ano seguinte ela ia para a sala de seis anos, ano cheio; sete anos, ano cheio. Toda a criança que iria para primeira série, ela faria sete anos até 31 de dezembro, só que quando chega ano passado com o fundamental de nove não foi mais ano cheio. Na comissão: São Paulo era junho, aqui ficou em março. Então aquelas crianças que estavam comigo que entraram no infantil com o ano cheio de repente na hora de entrar no fundamental não era mais ano cheio, teve corte. Por isso que fiquei com crianças que ficaram na turma de nove anos e outras na turma de oito anos. (Diretora, 2010)
\end{abstract}

Pode-se perceber que existiu muita confusão com relação à matrícula das crianças no ensino fundamental de oito e de nove anos dentro do município e, principalmente, entre as redes municipais e estaduais, pois como cada Município ou Estado se organizou de uma

\footnotetext{
${ }^{13}$ A partir desse momento, a denominação utilizada nesta Dissertação para se referir ao $1^{\circ}$ ano do ensino fundamental de nove anos e ao $1^{\circ}$ ano do ensino fundamental de oito anos será, respectivamente, $1^{\circ}$ ano EF9 e $1^{\circ}$ ano EF8.
} 
maneira diferente, aderindo a nova organização em anos diferentes ou utilizando diversas datas de corte, quando ocorria uma transferência entre crianças de redes distintas, muitas vezes, as escolas e os pais, na hora de matricular as crianças, não sabiam exatamente em que ano/série matricular, como se constata na fala da diretora da escola:

\begin{abstract}
O problema às vezes acontece quando vem transferências de outros estados porque aqui nós começamos com o fundamental de 9 este ano, em 2010, só que tem estados, principalmente do nordeste, em que faz tempo que eles mudaram porque tiveram cinco anos para se adequar. E quando você pega, o menino está lá no $2^{\circ}$ ano do fundamental de 9 anos só que aqui equivale ao $1^{\circ}$ ano do EF8 e vai convencer este pai. Porque o pai quer matricular a criança no segundo de oito anos. Então nós estamos funcionando paralelamente, vocês perceberam? Noutro dia veio uma mãe do Rio Grande do Sul e ela ficou brava e disse que iria falar com a Secretária da Educação. Expliquei para ela que transferência de outro estado aqui equivale pela idade e mostrei a resolução. O menino está alfabetizado, e eu falei que poderia pensar para o próximo ano fazer uma reclassificação. Mas ele não tem defasagem idade/série, mas por aprendizagem a gente pode pensar nisso. O menino tinha idade para estar num $2^{\circ}$ ano de EF9 e não num $2^{\circ}$ ano EF8, que equivaleria ao $3^{\circ}$ ano EF9, então ele não entra em defasagem idade/série aqui não. Eu expliquei para a mãe que ele iria terminar no mesmo tempo que ele terminaria lá. Porque lá ele vai ter nove anos e aqui ele vai ter oito. Então é difícil para o pai, porque é tudo muito novo. (Diretora, 2010)
\end{abstract}

Ainda com relação aos pais, a diretora afirmou que, em alguns casos, os pais optaram por tirar seus filhos da rede pública e matriculá-los em escolas particulares, pois a rede privada começou a implementar a ampliação antes e não seguiu a mesma data de corte do município, podendo algumas crianças, que na rede pública ficariam mais um ano na educação infantil, se matricular no $1^{\circ}$ ano do ensino fundamental de nove anos, na rede privada. Com isso, a rede pública perdeu matrículas para a rede privada e estas crianças perderam um ano de escolaridade, entrando mais cedo no ensino fundamental.

Durante a realização da pesquisa de campo, foi perguntado aos entrevistados qual era a opinião deles sobre o motivo da ampliação do ensino fundamental para nove anos. É interessante observar que, uma professora do $1^{\circ}$ ano EF9, associou a ampliação com o FUNDEF: "Por conta do repasse de verbas, porque a gente acaba recebendo mais, porque são nove anos no ensino fundamental, e se é fundamental, é obrigado a frequentar, então eu acredito que seja por isso." (Professora 1, 2010). Porém, diferente dessa professora, a maioria dos entrevistados associou a mudança com a ampliação do direito a educação. Por exemplo, outra professora do $1^{\circ}$ ano EF9 afirmou que: "Foi para garantir o acesso das crianças à escola." (Professora 2, 2010).

A despeito da tentativa de universalização do ensino fundamental e da sua ampliação para nove anos, com argumentação de ampliação de direitos, verificou-se que as alterações não induziram ao aumento de matrículas nessa etapa de ensino, como se propunha. De acordo 
com a Tabela IV pode-se observar que as matrículas na educação infantil, das crianças de 5 (cinco) e 6 (seis) anos de idade, diminuiram do ano de 2005 para o ano de 2010, com exceção da matrícula das crianças de 5 (cinco) anos, do ano de 2006 para 2007, quando ela teve um pequeno aumento (92 matrículas), e a matrícula das crianças de 4 (quatro) anos e de 4 (quatro) a 6 (seis) anos de idade das escolas de tempo integral, também diminuiram do ano de 2009 para o ano de 2010:

Tabela IV - Total das Matrículas - Educação Infantil na Rede Municipal de São Bernardo do Campo (2004 - 2010)

\begin{tabular}{|l|l|l|l|l|l|l|l|}
\hline Idade/ Ano & 2004 & 2005 & 2006 & 2007 & 2008 & 2009 & 2010 \\
\hline de 0 a 11 meses & 47 & 114 & 133 & 108 & nc & 478 & 505 \\
\hline de 1 ano a 1 ano e 11 meses & 181 & 267 & 219 & 279 & nc & 700 & 788 \\
\hline de 2 anos a 2 anos e 11 meses & 485 & 599 & 447 & 547 & nc & 1195 & 1330 \\
\hline de 3 anos a 3 anos e 11 meses & 1375 & 1607 & 1862 & 1905 & nc & 4054 & 4303 \\
\hline de 4 anos a 4 anos e 11 meses & 3846 & 4461 & 4743 & 5367 & nc & 7142 & 6212 \\
\hline de 5 anos a 5 anos e 11 meses & 9405 & 9435 & 8584 & 8676 & nc & 8646 & 8453 \\
\hline de 6 anos a 6 anos e 11 meses & 10675 & 11231 & 10640 & 9669 & nc & 9047 & 8732 \\
\hline Integral de 4 a 6 anos & 1107 & 1121 & 1017 & 1141 & nc & 1302 & 1029 \\
\hline Total & 27121 & 28835 & 27645 & 27692 & nc & 32564 & 31352 \\
\hline
\end{tabular}

Fonte: Secretaria Municipal de Educação de São Bernardo do Campo

Obs: $\mathrm{nc}=$ nada consta

Com isso, pode-se constatar que houve decréscimo no total de matrículas na educação infantil, do ano de 2009 para 2010, de 1.212 matrículas. Porém, é importante destacar o crescimento significativo do atendimento em creches, das crianças de 0 a 3 anos de idade, no município de São Bernardo do Campo, no período analisado, de 2004 a 2010.

$\mathrm{Na}$ Tabela $\mathrm{V}$, que apresenta os dados da matrícula nos anos iniciais do ensino fundamental, pode-se perceber que o total da matrícula nesses anos, também, vem diminuindo desde 2004:

Tabela V - Total das Matrículas - Anos Iniciais do Ensino Fundamental do Município de São Bernardo do Campo (2004 - 2010)

\begin{tabular}{|c|c|c|c|c|c|c|c|}
\hline Anos Iniciais/ Ano & 2004 & 2005 & 2006 & 2007 & 2008 & 2009 & 2010 \\
\hline 10 ano & - & - & - & - & - & - & 5885 \\
\hline 20 ano/1을 Ano do Ciclo I & 12215 & 11793 & 11942 & 11305 & nc & 9817 & 5074 \\
\hline 30 ano/2 Ano do Ciclo I & 13111 & 13888 & 13218 & 13445 & nc & 11550 & 10869 \\
\hline 4ㅇ ano/1을 Ano do Ciclo II & 11756 & 11441 & 12267 & 11562 & nc & 11323 & 10340 \\
\hline
\end{tabular}




\begin{tabular}{|l|l|l|l|l|l|l|l|}
\hline 5o ano/20 Ano do Ciclo II & 12762 & 12506 & 12135 & 12697 & nc & 12256 & 11698 \\
\hline Total & 49844 & 49628 & 49562 & 49009 & nc & 44946 & 43866 \\
\hline
\end{tabular}

Fonte: Secretaria Municipal de Educação de São Bernardo do Campo

Obs: $\mathrm{nc}=$ nada consta

Por meio da análise da Tabela V, pode-se constatar que, de 2004 para 2010, o número total de matrículas nos anos iniciais do ensino fundamental diminuiu muito, totalizando 5.978 matrículas a menos, em 2010. Porém, percebe-se que o número de matrículas do $1^{\circ}$ ano EF9 e do $1^{\circ}$ ano EF8 juntos, aumentou em relação ao número de matrículas no $1^{\circ}$ ano EF8, em 2009 (1.142 matrículas), tendo, em 2010, aumentado o número de crianças ingressantes no ensino fundamental, com ampliação dessa etapa de ensino para nove anos.

Observando as Tabelas IV e V percebe-se a confusão da própria Secretaria de Educação, com relação às matrículas das crianças de seis anos, pois as crianças aparecem matrículadas tanto na educação infantil quanto no ensino fundamental, em 2010. Além disso, na Tabela VII - Total das Matrículas - Crianças de seis anos na Rede Municipal de São Bernardo do Campo (2004 - 2010) - as crianças de seis anos aparecem matriculadas apenas no ensino fundamental e com o número muito reduzido:

Tabela VII - Total das Matrículas - Crianças de seis anos na Rede Municipal de

São Bernardo do Campo (2004 - 2010)

\begin{tabular}{|l|l|l|l|l|l|l|l|}
\hline Etapa de Ensino / Ano & 2004 & 2005 & 2006 & 2007 & 2008 & 2009 & 2010 \\
\hline 1 ㅇ ano do Ensino Fundamental & - & - & - & - & - & - & 5885 \\
\hline Educação Infantil & 10675 & 11231 & 10640 & 9669 & nc & 9047 & - \\
\hline
\end{tabular}

Fonte: Secretaria Municipal de Educação de São Bernardo do Campo

Obs: $\mathrm{nc}=$ nada consta

Se observarmos, na Tabela IV, o número de crianças de 5 anos a 5 anos e 11 meses, matriculadas em 2009, totalizava 8646 crianças. Fica a seguinte questão: aonde foram parar as 2761 crianças que teriam 6 anos, em 2010, e deveriam estar matriculadas no ensino fundamental?

Além disso, no que se refere aos dados educacionais do Município percebe-se que o movimento de garantia de acesso à educação não se alterou efetivamente com as novas mudanças, tendo inclusive diminuído, em números significativos, as matrículas na pré-escola, no ano de 2010, assim como a matrícula nos anos iniciais do ensino fundamental, ano em que foi implantado o ensino fundamental de nove anos na rede. Nesse sentido, é importante 
lembrar, como afirma Correa, que: “o PNE aprovado em 2001 estabelecia como meta a ampliação do EF, mas também o aumento de vagas na educação infantil, tanto na creche quanto na pré-escola, para crianças de 4 e 5 anos.” (CORREA, p. 117, 2011):

1) Ampliar a oferta de educação infantil de forma a atender, em cinco anos, a $30 \%$ da população de até 3 anos de idade e $60 \%$ da população de 4 e 6 anos (ou 4 e 5 anos) e, até o final da década, alcançar a meta de $50 \%$ das crianças de 0 a 3 anos e $80 \%$ das de 4 e 5 anos. (BRASIL, 2001, p. 14)

Ressalte-se, ainda, que, apesar de muitos documentos afirmarem que a nova organização da Educação Básica no Brasil seria o corolário da ampliação do direito à educação, pelas vias da obrigatoriedade e gratuidade, não foi verificado avanço, ou seja, não houve aumento do número de matrículas e, ao mesmo tempo, estagnou-se o aporte de recursos para a manutenção e desenvolvimento do ensino.

Outro fator importante a ser destacado foi a falta de opção dada aos pais, para escolha da matrícula de seus filhos, pois eles não puderam escolher manter seus filhos por mais um ano na educação infantil, ao invés de matriculá-los no ensino fundamental, o que causou desconforto para alguns pais entrevistados. Quando perguntados se teriam preferido que seus filhos cursassem mais um ano na educação infantil ou no ensino fundamental, eles afirmaram:

\footnotetext{
"No começo eu deixaria na educação infantil, se eu pudesse falar eu deixaria ela mais um ano no pré.” (Responsável 1, 2010)

"Na educação infantil, eu acho que para ele era melhor ficar mais um ano, porque se ele ficasse mais um ano ele já viria mais forte para cá.” (Responsável 2, 2010)

"Eu preferia que ele ficasse no infantil, para melhorar mais um pouco, eu acho que ele é muito precoce para já ir para o $1^{\circ}$ ano.” (Responsável 3, 2010)
}

Por meio das entrevistas realizadas com as crianças pode-se perceber que, apesar da escola pesquisada estar inserida em uma comunidade carente, todas as crianças já frequentavam uma escola de educação infantil, localizada próxima de suas residências, o que mostra que o ensino fundamental de nove anos não significou um avanço no direito à educação destas crianças, mesmo elas sendo de baixa renda familiar. Além disso, algumas crianças responderam que gostavam mais da escola em que estudavam antes e que preferiam continuar estudando lá mais um ano:

\footnotetext{
"Eu queria estudar na outra, porque lá tinha mais brinquedo" (Criança 1, 2010)

"Sabia que às vezes eu choro nessa escola? Porque eu fico com saudades da outra escola." (Criança 2, 2010)

"Eu preferia na outra porque lá era mais legal, a outra professora era mais legal, tinha duas professoras." (Criança 3, 2010)
} 
Por fim, cabe refletir sobre o direito das crianças menores de seis anos, da educação infantil que, como visto anteriormente, não tiverem aumento no número de matrículas com a entrada das crianças de seis anos no ensino fundamental. Além disso, Marin e Pansini (2011) apresentam importante preocupação com relação às crianças de cinco anos:

Outra preocupação se dá em relação às crianças de 5 anos que permanecem na EI, para as quais não se buscou qualificar os critérios de ensino e ingresso, de modo que poderão, de agora em diante, ser oferecidas a elas as mesmas estratégias e atividades realizadas pelas antigas turmas de 6 anos. Essa situação pode ampliar a tendência, cada vez maior, de que o EF "engula" as crianças mais novas, "pela diminuição das matrículas, devida à queda das taxas de fecundidade, como também pela indefinição, até o presente, de fontes de financiamento para a educação infantil” (SANTOS, VIEIRA, 2006, p. 787 apud MARIN e PANSINI, p. 93, 2011) 


\section{Reflexões sobre o ensino fundamental de nove anos e a gestão democrática.}

Se eu fosse presidente desta escola eu ia mudar para a gente ir na brinquedoteca nos finais de semana e nas sextas-feiras. (Criança 1) Eu também ia querer que a gente fosse para quadra todo dia. (Criança 3)

Pretende-se descrever nesse capítulo, os resultados da pesquisa em relação à gestão democrática, ou seja, apresentar se na elaboração das propostas de implantação do ensino fundamental de nove anos houve registro de realização de debates de órgãos executivos com a comunidade escolar sobre o tema da ampliação. Tratava-se, assim, de investigar por quais instâncias as discussões sobre o ensino fundamental de nove anos passaram, para que fossem feitas as adequações e orientações pedagógicas realizadas pela Secretaria de Educação e pela escola, em relação às alterações exigidas pela nova legislação de organização do ensino fundamental. E também saber, a partir das opiniões dos pais, se eles receberam orientação, se conheciam o Projeto Político Pedagógico da escola e a proposta de trabalho para o primeiro ano e se participaram da elaboração das mesmas.

\subsection{Gestão Democrática no Brasil e o ensino fundamental de nove anos}

A Constituição Federal de 1988 foi a primeira a garantir, como princípio do ensino, a gestão democrática (artigo 206, inciso VI), isso se deve, em parte, à existência de movimentos nacionais voltados para a redemocratização do país, com o fim do período da ditadura militar (1964-1985). A inserção desse princípio foi um avanço e uma conquista para a educação, pois, como afirmam Adrião e Oliveira (2001):

\footnotetext{
A democracia como princípio articula-se ao da igualdade ao proporcionar, a todos os integrantes do processo participativo, a condição de sujeitos expressa no seu reconhecimento como interlocutor válido. Como método, deve garantir a cada um dos participantes igual poder de intervenção e decisão, criando mecanismos que facilitem a consolidação de iguais possibilidades de opção e ação diante dos processos decisórios. (ADRIÃO; OLIVEIRA, 2001, p. 77)
}

Porém, a idéia de gestão democrática do ensino só aparece nesse artigo e, acompanhada da expressão genérica "na forma da lei", o que delega sua normatização à legislação complementar, ou seja, à Lei de Diretrizes e Bases da Educação - LDB/96 (Lei federal $n^{\circ}$ 9.394/96). Em seu artigo $3^{\circ}$, a LDB definiu a gestão democrática como um dos princípios do ensino, mas, repetiu a fórmula da Constituição Federal, passando a 
responsabilidade pela definição e regulamentação da gestão democrática aos sistemas de ensino: "gestão democrática do ensino público na forma desta Lei e da legislação dos sistemas de ensino". Além disso, outra limitação do artigo 206, da CF/88, era que o princípio da gestão democrática só se referia ao ensino público, excluindo a extensão do princípio ao ensino privado, o que limita e compromete a concepção de gestão democrática.

No Art. 14, a LDB/96 estabeleceu os princípios que deveriam nortear as normas da gestão democrática, definindo a participação dos profissionais da educação e das comunidades escolar e local na gestão:

Art. 14. Os sistemas de ensino definirão as normas da gestão democrática do ensino público na educação básica, de acordo com as suas peculiaridades e conforme os seguintes princípios:

I - participação dos profissionais da educação na elaboração do projeto pedagógico da escola;

II - participação das comunidades escolar e local em conselhos escolares ou equivalentes (BRASIL, 1996b).

Apesar da LDB/9394 trazer alguns avanços no que diz respeito à gestão democrática, PARO (2001) considera esse artigo “uma pobreza sem par”, pois:

\begin{abstract}
O primeiro princípio é o que há de mais óbvio, já que seria mesmo um total absurdo imaginar que "a elaboração do projeto pedagógico da escola" pudesse dar-se sem a "participação dos profissionais da educação". O segundo (e último!) princípio apenas reitera o que já vem acontecendo na maioria das escolas públicas do país. Além disso, ao prever a "participação das comunidades escolar e local em conselhos escolares ou equivalentes", sequer estabelece o caráter deliberativo que deve orientar a ação desses conselhos... (PARO, 2001, p. 81,)
\end{abstract}

O Plano Nacional de Educação (2001) retomou a questão da gestão democrática especificando que os Conselhos de Educação, formados por representantes dos diversos setores educacionais e profissionais com competência técnica, deviam atuar em nível de gestão de sistema, enquanto os conselhos escolares, representando toda comunidade escolar participariam da gestão, em cada escola.

Embora a gestão democrática seja um direito garantido no corpo das leis, percebe-se que ainda são poucas as experiências de efetivação prática. O mais comum, infelizmente, são decisões de política pública tomadas pela autoridade superior constituída, sem consulta ou participação da população usuária do serviço, como será descrito a seguir com implementação da ampliação do ensino fundamental para nove anos.

$\mathrm{Na}$ apresentação do documento federal "Ensino Fundamental de nove anos: orientações gerais" (BRASIL, 2004a), era apontado um aspecto relevante ao debate proposto 
naquele momento: a realização do documento como o resultado do exercício da gestão democrática, do diálogo entre o Ministério da Educação e os sistemas de ensino, conforme o trecho abaixo:

\begin{abstract}
“Ao colocar-se como indutor de políticas educacionais, o Ministério da Educação desenvolve uma metodologia de trabalho de articulação com os sistemas de ensino e com as diversas entidades voltadas para a questão educacional, uma vez que o exercício da gestão democrática deve ter como princípio a construção das políticas públicas em conjunto com os atores sociais nelas envolvidos. Em conformidade com o sistema federativo brasileiro, o Ministério da Educação tem a expectativa de que esses atores educacionais estabelecerão uma interlocução construtiva com as escolas, tendo em vista a ampliação do Ensino Fundamental para nove anos.”. (BRASIL, 2004a)
\end{abstract}

O Documento trazia, em anexo, o Primeiro Relatório do Programa, de Julho de 2004, que mencionava o início do processo de discussão do tema (meta do Plano Nacional de Educação) com Estados e Municípios. O documento referia-se aos sete encontros regionais (nas seguintes cidades: Belo Horizonte, Campinas, Florianópolis, São Luis, Recife, Rio Branco e Goiânia), ocorridos no início de 2004, nos quais a pauta era a implementação desta política e pretendia informar sobre as ações desenvolvidas até então. O Relatório apontava a participação de 247 Secretarias de Educação, sendo todas elas manifestantes de interesse na ampliação imediata. Além das Secretarias, o Relatório indicava participação de representantes da União Nacional dos Dirigentes Municipais de Educação (UNDIME), do CNE, equipes técnicas das Secretarias e educadores de forma geral (supervisores, diretores, professores, orientadores pedagógicos, entre outros).

Apesar da tentativa do Governo Federal de realizar a discussão com diversas Secretarias de Educação, a participação de apenas quatro Secretarias de Educação Estaduais e 247 municípios é uma parcela pequena dentre os 27 estados e 5.565 municípios brasileiros ${ }^{14}$ (os números participantes da discussão representavam, respectivamente, 15,4\% e 5\% dos estados e municípios brasileiros). Além disso, ao manifestar que todos os representantes presentes nas reuniões concordaram e tinham interesse na ampliação do ensino fundamental, pode-se dizer que essa era uma aparente unanimidade entre os representantes dos sistemas de ensino brasileiros que tinham intenção e interesse na ampliação. Klein (2011), levanta um questionamento sobre essa coincidência:

Cabe suscitar aqui uma "estranheza", de que nestes encontros tenham participado somente municípios que aprovavam a ampliação, sendo estes espaços, conforme o

\footnotetext{
${ }^{14}$ Dados refrentes ao Censo 2010, realizado pelo IBGE.
} 
próprio Relatório diz, de assistência técnica. Seriam estes encontros então, legítimos para justificar uma posição nacional sobre a ampliação? Poderiam ser eles, como foram, chamados de espaços democráticos de discussão e decisão sobre tal matéria? (KLEIN, 2011, p. 146).

Assim, mesmo sem ouvir todos os estados, o Distrito Federal e a maioria dos municípios brasileiros, na introdução do Documento era informado o aceite da ampliação do ensino fundamental para nove anos de duração, com ingresso aos seis anos de idade em todo país. Observe-se que esta era uma política pública elaborada, segundo o MEC, dentro do princípio da gestão democrática, conforme citado anteriormente.

Em 2004 e 2005, o Conselho Nacional de Educação realizou estudos para definição de normas nacionais para a implementação do ensino fundamental de nove anos, nos termos do Parecer CNE/CEB no 24/2004 e do Parecer CNE/CEB 06/2005. O primeiro Parecer apontava que uma minoria era contrária à ampliação, mas considerava que “(...) o ingresso no Ensino Fundamental aos seis anos é assunto polêmico, com posições divergentes.”, (BRASIL, 2004c) demonstrando, assim, a necessidade de maior discussão sobre o tema.

Já o segundo Parecer, deixava clara a preferência pela implementação massiva do ensino fundamental de nove anos, mas, o voto dos Relatores: Murílio de Avellar Hingel, Maria Beatriz Luce e Arthur Fonseca Filho, mantinha a indicação da necessidade do debate envolvendo todos os segmentos interessados. Apesar disso, ao mencionar algumas normas para a implantação progressiva do ensino fundamental de nove anos, retirava do texto o trecho "se a opção for pela implantação progressiva" e adotava uma escrita mais decisiva "na implantação progressiva do ensino fundamental com duração de nove anos". Ficava declarado, portanto, que havia se encerrado o processo de discussão e participação sobre o tema. No ano seguinte é publicada a Lei $n^{\circ} 11.274 / 06$, que definiu a nova organização do ensino fundamental.

Após a aprovação da Lei, o Documento "Ensino Fundamental de nove anos: orientações para a inclusão das crianças de seis anos de idade" (BRASIL, 2006d), dava a entender, novamente, que havia existido uma opinião unânime em relação a essa medida, entre aqueles que trabalhavam na área. De acordo com Jacomini e Klein (2011):

O documento intitulado "O Ensino Fundamental de nove anos: orientações para a inclusão da criança de seis anos de idade" (SEB/MEC, 2006), publicado três meses após a promulgação da lei $11.274 / 06$, previa a necessidade de revisão de dois pontos fundamentais para a implementação do Ensino Fundamental de nove anos: o currículo das séries iniciais do Ensino Fundamental e a formação docente, sobretudo nos aspectos da brincadeira e da alfabetização. Apesar dessas preocupações, não há no 
documento qualquer referência a debates anteriormente realizados com a comunidade escolar, e dá a entender que essa decisão traduz unanimidade de posição entre docentes e especialistas. (JACOMINI; KLEIN, 2010, p. 8)

Além disso, o documento do MEC afirmava que:

Em se tratando dos aspectos administrativos, vale esclarecer que a organização federativa garante que cada sistema de ensino é competente e livre para construir, com a respectiva comunidade escolar, seu plano de ampliação do ensino fundamental, como também é responsável por desenvolver estudos com vistas a democratização do debate, o qual deve envolver, portanto, todos os segmentos interessados em assegurar o padrão de qualidade do processo ensino-aprendizagem. (BRASIL, 2006d, p. 7)

Sendo assim, será analisado a seguir como se deu o processo de implementação do ensino fundamental de nove anos no Município de São Bernardo do Campo, se o projeto foi discutido com toda comunidade escolar e qual era a opinião dos envolvidos sobre essa mudança.

\subsection{O ensino fundamental de nove anos e o princípio da gestão democrática no município de São Bernardo do Campo}

A escola é muito legal, a gente brinca, a gente tem que ouvir a professora e não tem que responder. (Criança 11)

No município de São Bernardo do Campo, a Lei 11.274, que ampliou o ensino fundamental para nove anos, só foi implementada no último ano previsto para a sua ampliação, ou seja, em 2010. De acordo com a Secretária de Educação, Professora Cleuza Repulho, a implantação não aconteceu como deveria ter sido, pois ela assumiu a Secretaria de Educação de São Bernardo em 2009, junto com a nova Administração Municipal (2009 2012), sem receber nenhuma documentação de anos anteriores, tendo que recorrer ao Instituto Nacional de Estudos e Pesquisa (INEP) para conseguir os dados educacionais do município. Assim, a nova Administração teve apenas sete meses para iniciar a implantação do ensino fundamental de nove anos, para conversar com os professores, com as famílias e reorganizar as escolas para receber as crianças de seis anos. A Professora Cleuza Repulho, na entrevista realizada em março de 2011, afirmou que:

Infelizmente, o processo de implantação não foi como deveria ter sido. Eu fui Secretária de Educação de Santo André por sete anos, e lá já em 2005, quando da legislação que estava em tramitação nós já começamos com o ensino fundamental 
de nove anos porque nós não tínhamos rede municipalizada. Em Santo André era rede própria de ensino fundamental, então ficou bem mais tranqüilo. Quando nós assumimos aqui, em 2009, foi que eu soube que esta foi a única secretaria de todas as outras que não houve transição, eu não recebi nenhuma documentação, nenhum arquivo onde eu tinha dados sobre, para vocês terem uma idéia, a empresa que cuidava dos dados da educação tinha vencido o contrato, este não tinha sido renovado, portanto eu cheguei aqui e não sabia nem o número de alunos. Nós usamos, como eu tinha trabalhado no Ministério da Educação, no ano de 2008, no ano inteiro lá em Brasília, eu liguei para o INEP. Conseguimos os nossos dados e a partir daí já fizemos um diagnóstico da rede de ensino que era fundamental, porque nós temos um Plano de Governo, um programa de governo que foi aprovado pela população e teríamos que implantá-lo e uma das questões era a implantação do ensino fundamental de nove anos e o último ano de implantação era 2010. Nós assumimos em 2009 então teríamos que fazer a implantação em 7 meses. O que significou isso? Conversar com os professores, conversar com as famílias, reorganizar as escolas para receber os alunos do fundamental. (Secretária de Educação de São Bernardo do Campo, 2011).

Percebe-se que, apesar da Lei ter sido aprovada em 2006 e a orientação do Governo Federal ter sido de que as redes tivessem até 2010 para se adequaram a nova organização, isso não ocorreu no município de São Bernardo do Campo, que teve apenas sete meses, a partir da nova Gestão, para discutir com a rede e a comunidade, a adequação a essa mudança. Apenas no ano anterior à ampliação (2009), a Secretaria de Educação promoveu discussões para a elaboração de um Documento, que subsidiaria as discussões nas escolas, denominado: "Orientações para a implantação do ensino fundamental de 9 anos"15 (SÃO BERNARDO DO CAMPO, 2010a). Essas orientações foram enviadas a todas as escolas, primeiro de maneira digitalizada e depois impressa. Lê-se no Documento, sobre esses encontros, que:

Durante o ano de 2009 foram realizadas diferentes reuniões com grupos de diretores e representantes das escolas do ensino fundamental para discutir aspectos do trabalho a ser realizado pelo ensino fundamental de 9 anos como a valorização da cultura da infância, a organização do recreio, a importância do brincar no espaço escolar, a abordagem lúdica das diversas áreas do conhecimento, a organização da rotina. Essas discussões contribuíram na fundamentação da elaboração das orientações dos temas presentes nesse documento. (SÃO BERNARDO DO CAMPO, 2010a, p. 4)

A diretora da escola pesquisada informou que participou dessas reuniões, em 2009. Disse que eles discutiram sobre a idade de corte a ser adotada na rede, que foi diferente da estabelecida para o Estado de São Paulo, pois no Estado foram matriculadas no $1^{\mathrm{o}}$ ano EF9 crianças que faziam aniversário até o mês de junho do ano letivo, enquanto que, em São Bernardo do Campo optou-se por manter a data de corte no dia 31 de março do ano letivo.

\footnotetext{
${ }^{15}$ Durante conversa informal na Secretaria Municipal de Educação, em março de 2010, uma funcionária mostrou o Documento e informou sobre os encontros à pesquisadora.
} 
Ela também contou que eles leram e discutiram as leis que fundamentaram a ampliação, analisaram como o ensino fundamental de nove anos foi implementado em outras redes, como a de Santo André, os encaminhamentos que deveriam levar para os outros diretores e foram organizando os objetivos para colocar no Projeto Político Pedagógico das escolas:

\footnotetext{
Eu fiz parte da comissão. Eles elaboraram uma comissão para que fosse implantado na rede, o fundamental de nove anos. Foi uma loucura, tinha data de corte. O Estado de São Paulo tinha outra data diferente daqui. Ano passado começaram com a data de corte em março e agora parece que mudou. (...) Discutimos as leis que fundamentaram, bastante leitura. A pesquisa de como seria implantado em outras redes. Na época Santo André já tinha, nós pesquisamos São Paulo, foi muita discussão (...) Na comissão que eu fiz parte o que saiu foi a idade de corte, os encaminhamentos que deveríamos passar para os diretores baseados no livro "Ensino Fundamental de nove anos" do MEC. Nos baseamos nele esse ano e fomos organizando os objetivos para o PPP. (Diretora, 2010)
}

Porém, apesar da diretora ter participado dessa Comissão, durante o ano de 2009, até o momento da Pesquisa ela não havia participado de outras discussões sobre o assunto, e menos, ainda, antes da Lei 11.274/2006.

$\mathrm{Na}$ Apresentação do Documento estava descrito como objetivo o de "dar orientações iniciais para desencadear as discussões a respeito de currículo nas escolas de Ensino Fundamental, envolvendo toda a equipe escolar na produção do Currículo do Ensino Fundamental de nove anos." (São Bernardo do Campo, 2010, p. 2) E que "as escolas terão como período para discussão de Fevereiro a Abril, momento este que incorporarão esta discussão ao PPP (Projeto Político Pedagógico) de cada Unidade Escolar." (São Bernardo do Campo, 2010a, p. 3).

Porém, na escola pesquisada, no final do $1^{\mathrm{o}}$ semestre de 2010 , durante conversa informal com a diretora da escola, ela mostrou o Documento e disse que a escola recebeu essas orientações no início do ano, mas quando perguntado para as professoras do $1^{\circ}$ ano EF9 se elas haviam recebido ou mesmo lido esse material, elas afirmaram nunca ter visto o material, sendo as pesquisadoras as primeiras a mostrá-lo para as professoras entrevistadas. Isso mostra como, muitas vezes, as informações são desencontradas, entre dirigentes e a base educacional, pois se o Documento deveria servir como orientador para as discussões na escola e estas deveriam ter ocorrido até abril para ser incorporadas ao PPP, de nada serviram na escola pesquisada, pois as professoras sequer tiveram contato com o material antes do final do semestre. 
Por meio da leitura do Livro de Registro das Reuniões de HTPC, a partir de 2009, pode-se verificar alguns dos momentos onde houve discussão na escola sobre a ampliação do ensino fundamental para nove anos.

Em 2009, foram encontrados apenas dois registros relativos à discussão sobre a ampliação do ensino fundamental. O primeiro, sobre a possibilidade das professoras da escola participarem de um curso on-line denominado "A criança de seis anos no Ensino Fundamental" oferecido pela Editora Moderna em parceria com a Secretaria de Educação do município, porém, como se pode verificar depois, nenhum professor da escola fez o curso. E o segunto, sobre uma discussão para o planejamento das salas para o próximo ano letivo (2010), onde constava a previsão de abertura de duas salas de $1^{\text {a }}$ série do ensino fundamental de oito anos e três salas de $1^{\circ}$ ano do ensino fundamental de nove anos. Porém esta previsão foi alterada, posteriormente, sendo abertas quatro salas de $1^{\mathrm{a}}$ série do EF8 e quatro salas de $1^{\mathrm{o}}$ ano do EF9.

No ano de 2010, pode-se observar mais momentos de discussão sobre a nova organização do ensino fundamental. Em março, os professores discutiram como seria feita a Ficha de Rendimento do $1^{\mathrm{o}}$ ano EF9, tendo havido uma conversa sobre a importância da primeira infância e do lúdico em todos os anos/séries do ensino fundamental. Ainda no mês de março, as professoras levantaram a questão do banheiro indequado para as crianças pequenas, a falta de estrutura no parque para as crianças, pois havia muitos brinquedos quebrados e faltavam inspetores para ajudar a olhar as crianças, além das mesas indequadas para o $1^{\circ}$ ano EF9.

Com relação à compra de mesas e ao conserto dos brinquedos do parque, a diretora afirmou que não poderia fazer muita coisa, pois a verba que a escola recebia não podia ser utilizada para esse tipo de gasto, pois era a Secretaria de Educação do Município que fazia esses reparos e mandava as cadeiras e mesas novas para as escolas.

Em abril, junho, setembro e novembro constava no livro mencionado que havia sido realizado o Pré-Conselho dos $1^{\circ}$ anos do EF9 e dos $1^{\circ}$ anos EF8, não havendo mais detalhes sobre a realização dos mesmos.

Sendo assim, pode-se constatar que as discussões foram mais informativas e administrativas sobre a nova organização do ensino fundamental, que reflexivas ou buscando uma participação maior da comunidade escolar para discutir o tema.

A diretora disse que, além das reuniões de HTPC, o ensino fundamental de nove anos também foi discutido no Conselho de Escola. Ela afirmou que apresentou a legislação no Conselho, porém não se referiu a nenhuma discussão mais prolongada sobre a opinião dos 
participantes, citando apenas que poucos pais participavam das reuniões, sendo essa uma dificuldade da escola.

A professora que representava os docentes no Conselho de Escola, na entrevista, afirmou também que as mudanças foram discutidas nas reuniões do Conselho, porém, que estavam presentes na Reunião aproximadamente quatro mães apenas. Sobre a discussão ela afirmou que:

\begin{abstract}
Teve muitas discussões principalmente com a primeira série, com adequação da sala. Que nem igual: a criança vem com a faixa etária menor e aí já querem fazer a mesma coisa que o ensino de oito anos, só que a sala não ta separada e a criança está em uma faixa etária diferente. Então eu acho que a gente bateu muito, discutiu muito na questão do material e adequação da sala. E não só da sala, os conteúdos também, porque a cabecinha deles gente dá dó. Então foi isso. (Professora Representante do Conselho de Escola, 2010)
\end{abstract}

Também foram entrevistadas juntas, duas funcionárias da escola, que faziam parte do Conselho de Escola e que também eram mães de alunos da escola. Elas afirmaram que ficaram sabendo da mudança pela escola, que, no Conselho, a diretora explicou que fizeram a Lei para ampliar o ensino fundamental para nove anos, que isso já era assim em outros países e que o município de São Bernardo do Campo, ainda não havia se adequado.

Uma das duas mães não se lembrava direito da discussão afirmando que "Comigo não foi discutido, não. Foi falado rápido apenas para deixar os pais cientes.”(Funcionária do Conselho de Escola, 2010) Sobre a discussão da criação da brinquedoteca na escola, a mesma funcionária disse que foi "mais um comunicado." (idem)

Diante do exposto é possível perceber que, embora a escola contasse com um Conselho de Escola, ainda havia pouca participação da comunidade escolar nele, não ocorrendo, de fato, uma gestão democrática participativa.

Segundo Paro (1998) existem dois tipos de participação da comunidade local nas escolas, uma ligada à tomada de decisões e, outra, à execução de tarefas. Para o autor, a participação efetiva é a que está ligada à tomada de decisões e, portanto, partilha do poder de decisão, no entanto, na realidade da escola pública brasileira o que se observa, quando existente, é o predomínio da participação executiva.

Além disso, durante a pesquisa, pode-se verificar que não havia consenso quando se discutia a ampliação do ensino fundamental e o ingresso de crianças de seis anos nesta etapa de ensino. Havia diversas opiniões da comunidade escolar sobre o tema, que não foram consideradas no momento da elaboração e implementação dessa política. Os professores, por exemplo, afirmaram não ter sido consultados por nenhum órgão superior sobre a elaboração 
das alterações necessárias para o atendimento dessa nova faixa etária no ensino fundamental. Eles disseram ter sido apenas informados, nas reuniões de HTPC, de que a implementação ocorreria em 2010 e que a escola precisaria se adequar de acordo com a Lei. A este respeito, Maria Isabel de Almeida considera que:

Se entendemos o professor como um profissional reflexivo, que toma decisões, avalia, seleciona e constrói sua forma de agir e interagir com os educandos, a mudança pressupõe o seu envolvimento de forma total. Não é possível atribuir-lhe papel ativo nas atividades docentes circunscritas à sala de aula, sem que a participação também se estenda à tomada de decisão sobre os rumos que a educação deve tomar. Estou querendo dizer que a mudança em educação depende dos professores, de sua formação, e que, se pensamos assim, não há espaço para elaboração de mudanças em gabinetes, de forma externa às escolas e sem a participação dos professores. (ALMEIDA, 1999, p. 256 apud PARO, 2006, p. 97)

Com relação à participação dos pais no processo, será explicitado a seguir que eles, também, não participaram do processo, sendo apenas informados sobre a mudança. Para explicar aos pais a nova organização do ensino, onde as crianças que antes estudavam juntas na educação infantil, passariam a partir de então, a estudar, algumas no ensino fundamental de oito anos, enquanto outras estudariam no ensino fundamental de nove anos, a Secretária de Educação de São Bernardo do Campo afirmou que foram realizadas, em todas as escolas, reuniões com esses pais para explicar a mudança.

Ela disse, também, que no início houve muita confusão entre os pais, pois alguns achavam que seus filhos iam ficar atrasados nos estudos, preferindo que eles estudassem em séries mais avançadas:

.(..) a gente queria que também a família entendesse este processo, porque tinham dois amigos que estudavam juntos, onde um deles, no entendimento das famílias, iria passar de ano e o outro não, então para nós explicarmos qual era a diferença e, eu acho que o momento mais difícil foi a conversa com as famílias para explicação de que as crianças não seriam atrasadas ou adiantadas, que elas estariam em seu ciclo de acordo com a nova legislação, com a nova organização do sistema. Esta foi a parte mais difícil, mas sempre em reuniões pequenas para que as pessoas pudessem falar, pudessem perguntar, tirar todas as dúvidas, enfim, para esclarecer e os pais saírem sossegados. Essa era nossa preocupação maior, porque com os professores foi um pouco mais tranqüilo, o entendimento deles foi melhor até porque eles estavam estranhando que as outras redes haviam mudado e aqui ainda não. Então não foi tão complexo assim. Com os pais foi o entendimento deles de que as crianças não seriam prejudicadas, que é a preocupação de qualquer pai e mãe. (Secretária de educação de São Bernardo do Campo, 2011).

$\mathrm{Na}$ escola pesquisada, essa reunião foi realizada, em 2009, com os pais das crianças que estudavam no Infantil V e que iriam, a partir de então. para o ensino fundamental. Sobre essa reunião a diretora contou que: 
Foi tranquila a passagem, tive que fazer reunião com os pais. Nós temos aqui as salas do infantil cinco, nós tínhamos seis salas do passado para esse e dentro da sala eu tinha crianças que faziam seis anos em março e outras que faziam em primeiro de abril. Tive que dividir, chamar os pais e explicar a resolução para os pais e explicar que na escola havia dois modelos de primeiro ano, o de oito e o fundamental de nove anos. Muitos ficaram chateados porque o filho foi para o de nove e outro para o de oito. Mas não tem jeito, é lei. Não tem como você dar um jeitinho. (Diretora, 2010)

No documento do MEC intitulado "Ampliação do Ensino Fundamental para nove anos: $2^{\circ}$ relatório do programa" várias características apareceram destacadas para que houvesse um processo que visasse ao pleno desenvolvimento do educando em sua inserção no ensino fundamental de nove anos. Uma delas dizia: "É importante uma gestão participativa, compartilhada e que tenha como referência a elaboração coletiva do Projeto PolíticoPedagógico, contemplando a ampliação do Ensino Fundamental". (BRASIL, 2005b)

Visto que o Projeto Político Pedagógico da escola deveria considerar as novas metodologias que o ensino fundamental de nove anos demandava, com a inclusão das crianças de seis anos, perguntou-se aos pais, em entrevistas, como ficaram sabendo da mudança, se participaram da elaboração da nova proposta curricular e como era realizada sua participação na escola.

Todos os pais entrevistados afirmaram ter ficado sabendo da mudança pela escola, seja no final de 2009, para os pais que já tinha filhos matriculados na escola, cursando o Infantil V, seja no início de 2010, na primeira Reunião de Pais. Todos também disseram não ter participado da elaboração da proposta de trabalho do $1^{\circ}$ ano EF9 e a maioria afirmou que participavam das Reuniões de Pais e que sempre conversavam com a professora, na hora de buscar o filho, porém nenhum deles participava das reuniões do Conselho de Escola.

Com estes depoimentos pode-se afirmar que, se a opinião dos gestores e professores não foi levada em consideração na elaboração da política pública, os pais mal foram informados sobre essas mudanças, a não ser quando elas já estavam implementadas e, apenas, para serem informados, para se situarem, sobre a nova situação escolar dos seus filhos e não como sujeitos participantes das mudanças.

Com relação aos objetivos para o $1^{\circ}$ ano do ensino fundamental de nove anos, eles não estavam padronizados na rede de ensino municipal de São Bernardo do Campo, e ainda não havia orientações curriculares para o $1^{\circ}$ ano EF9 na rede de ensino, pois o objetivo era que as escolas construíssem seus objetivos ao longo de 2010. Assim, as escolas tiveram autonomia para discutir como seria o currículo desse novo $1^{\circ}$ ano, podendo construí-lo de forma coletiva dentro das escolas e de cada escola. 
A diretora da escola, na entrevista, afirmou que foram utilizados os documentos do MEC sobre o ensino fundamental e a educação infantil e que as professoras da educação infantil que trabalhavam na escola "trocaram idéias" com as professoras do $1^{\circ}$ ano EF9, durante o planejamento para a construção desses objetivos. Porém, uma das professoras entrevistadas, do $1^{\circ}$ ano EF9, afirmou que, em nenhum momento, elas haviam conseguido sentar para discutir o planejamento com as professoras de educação infantil, que antes trabalhavam com essas turmas e poderiam ter contribuido na contrução desse novo currículo.

Percebe-se que, apesar da iniciativa positiva da Secretaria de Educação, de não determinar os objetivos do $1^{\circ}$ ano EF9, dando autonomia às unidades, a escola perdeu um momento que poderia ter sido rico para a discussão coletiva sobre a nova organização e a escolha dos objetivos, a partir da realidade escolar local, já vivenciada pelas professoras da educação infantil que haviam tido maior contato com as crianças pequenas e que trabalhavam no mesmo prédio escolar.

É importante destacar as opiniões dos diversos segmentos entrevistados sobre a nova organização do ensino fundamental para nove anos. Para conhecê-las foi perguntado para todos os entrevistados, qual era a sua opinião sobre a ampliação do ensino fundamental para nove anos, com a entrada das crianças aos seis anos de idade no ensino fundamental e, obteve-se as mais diversas opiniões.

A Secretária de Educação afirmou concordar com a mudança, pois ela acreditava que deveriam trabalhar com as crianças da faixa etária que iria de 0 a 10 anos, não devendo haver uma ruptura tão grande da educação infantil para o ensino fundamental, como ela acreditava que ocorria em São Bernardo do Campo. Lá as escolas de ensino fundamental não tinham parque e tampouco espaço para as crianças brincarem, como nas pré escolas. Por isso, ela acreditava que com o ensino fundamental de nove anos essa ruptura diminuiria, podendo haver uma reflexão sobre a importância do lúdico em todos os anos:

Eu sou da linha de que a gente deveria trabalhar com a primeira infância, de 0 a dez anos, por isso eu sou a favor da municipalização de primeira á quarta ou agora do primeiro ao quinto ano. Porque no meu entendimento e na teoria que eu acredito, é uma fase que ela tem as suas divisões, mas é onde a criança é mais criança. Porque esta ruptura da pré-escola para o fundamental é muito drástica e aqui em São Bernardo isso é muito evidenciado. As escolas de ensino fundamental não têm parque, não tem espaço para as crianças brincarem como na pré- escola. Eu entendo diferente, que as crianças fazem 7 anos, mas elas gostam de escorregador, de balançar, de brincar na areia, ter os seus espaços. Brincar é necessário. (Secretaria de educação de São Bernardo do Campo, 2011). 
A diretora da escola pesquisada também concordou com a mudança, porém por motivos distintos. Ela disse que, como as crianças de seis anos já estavam sendo matriculadas no ensino fundamental, a Lei apenas legitimou o que já estava ocorrendo. Além disso, ela acreditava que as crianças teriam um ano a mais de ensino obrigatório, pois seriam nove anos e não oito, como era antes. E que era importante que se iniciasse aos seis anos, pois as crianças teriam mais tempo para se alfabetizar, pois o primeiro ciclo havia passado a ter a duração de três anos e não mais de dois, diminuindo assim, o número de retenções ao final do Ciclo I. Porém afirmou que era importante respeitar a especificidade das crianças de cinco e seis anos. Ela relatou que:

\begin{abstract}
$\mathrm{Na}$ verdade eles estão legitimando uma coisa que já acontecia. Crianças já vinham da educação infantil com essa faixa etária. Você sabe que a alfabetização é um processo, desde que você nasce já está se alfabetizando e também daí diminui o número de retenção. (...) No fundamental de nove anos, os três primeiros anos é o primeiro ciclo, antes tinha dois anos para serem alfabetizados. Foi melhor para o aluno. Eu acho que o ensino obrigatório ainda é de nove anos, porque o ensino médio não é obrigatório. (...) Eu concordo sim porque é uma oportunidade. Desde que respeite essa especificidade do aluno. Você não vai pegar um menino de cinco, seis anos e colocá-lo numa carteira, como era no meu tempo, aquela carteira cheirando à lustra-móveis impecável sentado. Você acabava aprendendo pelo medo. Agora você tem que construir essa aprendizagem, essa interação. É mudança para melhor. Não é deixar ele apenas sentado na carteira e dizer: - Brincar não é aqui é na rua, é em casa. Por que não na escola? (Diretora, 2010)
\end{abstract}

Já a vice diretora disse concordar parcialmente com a mudança, pois acreditava que a estrutura do ensino fundamental não era adequada para receber as crianças de seis anos, que a Lei tinha sido implantada, mas as escolas não foram preparadas antes e o currículo também não estava pronto:

\begin{abstract}
Parcialmente, porque eu acho que ainda a estrutura não é adequada, pensando na nossa realidade, não temos um banheiro adaptado, um parque, mesa, carteira adaptada. É como eu ouvi numa formação estamos trocando o pneu de um carro que está andando. A lei chegou foi implantada, mas o carro não está preparado. A estrutura não está adequada, mas eu acho que com o tempo tudo isso vai melhorando. Porque além da estrutura física, tem a parte documentária. Ainda não temos um currículo. Temos que adaptar o currículo anterior a esta demanda que está aí. Está tudo ainda sendo construído. Por isso eu concordo parcialmente, porque se estivesse tudo estruturado seria bom. (Vice-Diretora, 2010)
\end{abstract}

Duas professoras entrevistadas, uma da sala do $1^{\mathrm{o}}$ ano EF9 e a do Laboratório de Informática, afirmaram não ter uma opinião formada sobre o assunto, pois ainda era cedo para analisar se ia ser bom ou não para as crianças entrarem mais cedo no ensino fundamental. Uma delas afirmou que: “O ensino fundamental de nove anos anos é algo novo em nossa rede, 
a implantação está iniciando este ano e eu acredito que ainda é cedo para uma opinião a respeito." (Professora 1, 2010) A outra afirmou ter percebido, apenas, que as crianças chegavam mais imaturas e que as professoras tinham que estar preparadas para trabalhar com essas crianças:

Eu acho que é um processo. Não acho que tenho que concordar ou discordar, a gente está nesta mudança desde o ano passado. Os pontos negativos ou positivos veremos com o tempo. (...) Eu achei que vem mais imaturas, então a professora tem que estar preparada com esta fase, que não era uma preocupação da professora da $1^{\mathrm{a}}$ série porque eles eram diferentes. Agora eles vem menores, temos que ter outro foco, uma preocupação maior com a maturidade deles também. A gente precisa estar preparada para estes alunos, não é simplesmente trocou vamos mudar. Primeira série agora é fundamental de nove anos e a gente fazer o que bem entender, então temos que ter um respaldo, precisamos estar bem preparadas mas temos que ter alguém articulando isso, porque como é que o professor fará isso, quais são os objetivos a serem trabalhados com estes alunos da primeira série, inclusive no laboratório eu não tive respaldo nenhum para isso. Acabou acontecendo o que eu acho, conversando com o professor porque o meu respaldo é o professor. É o planejamento dele, se ele estiver perdido eu também vou ficar perdida. Por isso é muito importante este momento de sentar com o professor e planejar, ver o que ele está fazendo para eu tentar articular este trabalho com o trabalho aqui do laboratório de informática. (Professora 3, 2010)

A outra professora do $1^{\mathrm{o}}$ ano EF9 disse acreditar que tinha sido melhor para as crianças se adaptarem à escola, à rotina do ensino fundamental e ao processo de alfabetização, atendendo às crianças que não tem acesso à leitura e escrita em suas casas. Porém afirmou saber que a Lei tem relação com o repasse de verbas do Governo Federal para os municípios, e que esta é maior para o ensino fundamental e depende do número de matrículas no mesmo.

Disse também que é importante adequar o espaço, a rotina e os materiais:

Eu penso assim, como nós havíamos em anos anteriores crianças da EMEI aqui do lado, já tínhamos algumas dificuldades para adaptar estas crianças à nossa rotina para alfabetizar porque nós somos alfabetizadores apesar de que, entre aspas, não é obrigado a alfabetizar neste primeiro ano porque agora é um ciclo inicial com três anos para concluir a alfabetização. Ajuda as crianças a se adaptarem melhor a esta rotina do fundamental, que para mim é uma questão importante porque as crianças precisam de atividades diferenciadas para aguentar aqui cinco horas. Atende aquelas crianças que não tem nenhum acesso à leitura, nenhum acesso material a suportes de portadores de textos, eles não tem suporte nenhum. As famílias não conseguem ser portadoras de textos em casa ler com os filhos, então nesse sentido sim, deles poderem ter mais contato com leitura e com este mundo letrado. E a gente sabe que é pra ter um número maior de crianças no fundamental e a gente sabe que o repasse de verba também é maior do governo para o município, então acho que isso pesa um pouco também nesse sentido. (...) Acho que é uma questão que se a gente tivesse como adequar os espaços, adequar a rotina, adequar o repasse de verbas para as escolas para que os materiais pudessem chegar mais rápido na nossa mão eu digo que sim, porque é tudo um ganho. A gente conhece crianças do ensino particular, ensino privado que estão na educação e com quatro e cinco anos já sabem ler e escrever, não é? Se você fosse pensar que tivesse uma adequação de tudo isso, que a gente sabe que é uma coisa que a escola dá conta eu acredito que 
sim. É legal porque a gente sabe que as crianças aprendem, sendo estimuladas, elas aprendem. (Professora 2, 2010)

As representantes do Conselho de Escola entrevistadas tiveram opiniões diferentes. As funcionárias e mães de alunos da escola disseram concordar com a mudança, porém que a escola deveria ter sido melhor adaptada para as crianças, com carteiras, mesas e bebedouros, de acordo com o tamanho das crianças. Já a representante dos professores, no Conselho, afirmou não concordar com a mudança, por causa da faixa etária das crianças, e que elas seriam melhor atendidas na educação infantil:

\begin{abstract}
Por causa da faixa etária; gente, é a infância. Que nem quando vai do infantil vem para a primeira série tem uma queda porque o trabalho que é feito no infantil, quando chega na primeira série a cobrança de conteúdo é maior, não que no infantil não tenha, tem, mas no fundamental, sei lá parece que quebra alguma coisa né? Dá dó de ver esses pequenininhos assim. Por isso que a gente fala: precisa de uma adequação curricular da sala de aula, porque é judiar das crianças. (Professora Representante do Conselho de Escola, 2010)
\end{abstract}

A mesma professora, quando perguntada se conhecia a opinião dos demais professores da escola sobre a mudança, disse que existiam diversas opiniões: "Tem gente que concorda, tem gente que é a favor do antigo, tem gente que tanto faz, porque não trabalha com este ano." (Professora Representante do Conselho de Escola, 2010)

A opinião dos pais entrevistados também foi bem diversificada, sendo que três pais concordaram com a mudança: uma mãe afirmou que era bom que eles aprendessem desde cedo, outra mãe disse que as crianças, hoje, estavam mais evoluídas e inteligentes que antes, e que a escola era boa e um pai falou que era melhor que a criança ficasse desde cedo na escola do que na rua, "aprontando".

Já outras três mães ficaram divididas: uma, afirmou concordar com a mudança, pois acreditava que, assim, as crianças sairiam mais cedo da escola (mostrando seu desentendimento com relação a ampliação do ensino fundamental, pois as crianças sairiam dele com a mesma idade que antes). Quando perguntada se preferia que o filho estivesse no $1^{\circ}$ ano do ensino fundamental ou ficasse mais um ano na educação infantil, afirmou preferir que ele tivesse ficado mais um ano no Infantil, porque ele só conseguiu aprender algumas coisas do $1^{\circ}$ ano EF9 e ela acredita que, se ele tivesse ficado mais um ano na educação infantil, teria menor dificuldade no $1^{\circ}$ ano EF9. Outra mãe disse que concordava em parte, pois algumas crianças estavam se desenvolvendo bem, porém existiam outras que não estavam se desenvolvendo, então ela acreditava que não adiantava forçar, tinha que deixar cada uma seguir seu próprio ritmo. E a terceira mãe falou que, no caso de sua filha, a mudança tinha 
sido boa, pois ela tinha se desenvolvido mais, porém que existiam crianças com muita dificuldade para acompanhar o $1^{\circ}$ ano EF9 e que achava que era muito tempo para as crianças ficarem na escola. Ela afirmou, na entrevista, que:

\begin{abstract}
Eu vou falar particularmente com a (nome da filha) eu gostei porque ela desenvolveu muito mais, mas na sala dela tem crianças com dificuldade, daí eu não concordo igual a professora falou, por ela, ela trabalha diferente com essas crianças porque elas estão acostumadas a estar brincando, desenhando, então é um pouco de lição mas durante cinco horas é muita tortura para eles, a professora falou: a gente faz um trabalho diferente com eles, mas ainda tem crianças de acordo com a professora que estão tendo dificuldades, até ela falou que é perigoso até repetir porque tem crianças que o que as outras já sabem elas não sabem nem o começo. (Responsável 1, 2010)
\end{abstract}

Por último, três pais afirmaram não concordar com a mudança: um pai alegando que preferia como era antigamente, pois iam com mais calma no início da alfabetização, uma mãe afirmou que as crianças estavam entrando muito cedo na escola e a última mãe disse que eles eram muito novos, muito crianças para "entender a $1^{a}$ série".

Pode-se constatar, portanto, que, além das diferentes opiniões sobre a ampliação do ensino fundamental, com algumas pessoas concordando, outras discordando e outra, ainda, com muitas dúvidas sobre a nova organização, as opiniões foram muito ricas e com distintos argumentos, que deveriam ter sido levados em conta no momento das discussões sobre a criação e implementação da Lei.

Com relação à investigação da participação das crianças no processo, um dos objetivos da pesquisa, perguntou-se às professoras se o ensino fundamental de nove anos foi discutido com elas e se as professoras haviam conversado com as crianças sobre isso. A Professora 1 disse que "Não foi discutido, na verdade elas foram informadas." E a Professora 2 afirmou que:

\footnotetext{
Que eu me recorde, não. Teve com os pais, tanto que eu estava de licença gestante, mesmo assim eu vim e conversei com eles informando que eles não eram mais do infantil, mas do fundamental que mudou a nomenclatura, tanto que os pais tomaram ciência desta mudança na reunião inicial do ano. Quando a gente se apresenta e fala um pouco do trabalho, mas com os alunos é no decorrer. No início a gente falou um pouquinho que eles não estavam mais na turma de seis anos, que agora era outra nomenclatura, mas de uma maneira que faz com que ele entenda que agora eles estão numa turma de ensino fundamental e que eles não eram uma turma do infantil. É porque com criança não se entra em muitos detalhes, o que eles querem é vir para a escola e participar das atividades a discussão em si a gente não vai discutir com as crianças, não é? (Professora 2, 2010)
}

Pode-se perceber que, se os adultos envolvidos no processo, mal foram ouvidos, sendo mais informados sobre a nova organização escolar, as crianças - principais interessadas na 
mudança - foram as últimas a serem informadas, quando já estavam inseridas na mudança e sem qualquer possibilidade de opinar sobre seu destino, sendo que, como visto anteriormente, algumas preferiam continuar estudando nas escolas de educação infantil. Além disso, a própria professora acreditava que não precisava entrar em muitos detalhes com as crianças, demonstrando que a opinião das crianças, não tem prioridade ou importância nas escolas. 


\section{Reflexões sobre o ensino fundamental de nove anos e a qualidade da educação}

Uma escola tem que ter brinquedos novos e ter uma professora muito, muito, muito legal, que deixasse a gente só brincar mesmo. Depois que acabasse a aula de brincar, a gente fazia só um pouquinho de lição e a gente ia embora. (Criança 11)

Neste capítulo, será feita uma breve análise sobre o uso do conceito de qualidade no Brasil, para verificar, a seguir, se e de que forma o termo aparece nos documentos oficiais do Ministério da Educação, destacando-se os aspectos da qualidade que aparecem neles. Em seguida, serão descritas e analisadas as mudanças ocorridas na escola pesquisada para receber as crianças de seis anos no $1^{\circ}$ ano (rotina, espaço físico, formação dos professores, proposta curricular, entre outros) e se elas eram coerentes com as propostas governamentais de garantia da qualidade do ensino. Por último, serão apresentadas as opiniões dos envolvidos, a respeito do que seria considerado qualidade na educação das crianças de seis anos, em especial, a opinião das próprias crianças sobre como seria uma escola boa para elas, o que deveria ter e o que elas deveriam fazer nela.

\subsection{Discussão sobre qualidade da educação no Brasil e o ensino fundamental de nove anos}

O termo "qualidade no ensino" tem sido usado de forma indiscriminada, sendo entendida, normalmente, como "algo bom”. Porém, nem sempre ele é especificado, não havendo hegemonia sobre qual concepção de qualidade na educação deve ser adotada, de forma a garantir boas condições básicas de ensino para todos os estudantes. Araújo e Oliveira (2005) trazem uma preocupação com a possibilidade do termo desencadear falsos consensos:

\footnotetext{
Qualidade é uma palavra polissêmica, ou seja, comporta diversos significados e por isso tem potencial para desencadear falsos consensos, na medida em que possibilita interpretações diferentes do seu significado segundo diferentes capacidades valorativas. (ARAUJO E OLIVEIRA, 2005, p. 7).
}

No Brasil, diferentes autores, como Anisio Teixeira, José Mario Pires Azanha e Paulo Freire, entre outros, defenderam nos seus escritos que qualidade é um critério historicamente datado, e que sofre alterações em função de questões políticas e sociais.

O Manifesto dos Pioneiros da Educação Nova , de 1932, já trazia essa reflexão: 
Toda a educação varia sempre em função de uma "concepção da vida", refletindo, em cada época, a filosofia predominante que é determinada, a seu turno, pela estrutura da sociedade. E' evidente que as diferentes camadas e grupos (classes) de uma sociedade dada terão respectivamente opiniões diferentes sobre a "concepção do mundo", que convém fazer adotar ao educando e sobre o que é necessário considerar como "qualidade socialmente útil". (AZEVEDO et al, 1984)

Apesar da concepção apresentada no Manifesto, a preocupação com a qualidade do ensino, não foi prioridade no ensino público brasileiro. Na década de 40, as políticas públicas, começaram a se voltar para a questão do acesso à escola, pois grande parte das crianças brasileiras ainda estavam fora do sistema escolar, sendo o investimento, naquele momento, focado na construção de prédios escolares.

Nas décadas seguintes (70 e 80), com um número maior de crianças entrando para o sistema escolar, surgiu uma nova questão, relacionada à ideia de fluxo, pois se as crianças estavam entrando na $1^{\mathrm{a}}$ série, poucas estavam conseguindo concluir o ensino fundamental, sendo muito altos os números de reprovação e abandono escolar. Por isso, a década de 1990, foi marcada pela preocupação de se regularizar o fluxo escolar, através da adoção dos ciclos de escolarização, da promoção automática, dos programas de aceleração da aprendizagem e de orientações políticas de combate à reprovação escolar.

Porém, a partir dessas medidas, pode-se perceber um novo problema, ligado à aprendizagem escolar, pois, se agora os alunos estão concluindo o ensino fundamental em maior número, torna-se importante conferir a capacidade cognitiva dos alunos, que passou a ser aferida, a partir da década de 1990, por meio da utilização de testes padronizados em larga escala, pelo governo federal, inicialmente através do Sistema Nacional de Avaliação da Educação Básica (SAEB) e pelos governos estaduais e municipais, voltando-se a preocupação dos gestores educacionais à necessidade de garantia da qualidade escolar.

O artigo 206 da Constituição Federal de 1988, que estabelece os princípios pelos quais o ensino deverá ser ministrado, dispõe no inciso VII, a garantia de padrão de qualidade, e no artigo 211 , parágrafo $1^{\circ}$, que a União deverá garantir equalização de oportunidades educacionais e padrão mínimo de qualidade do ensino mediante assistência técnica e financeira aos Estados, ao Distrito Federal e aos Municípios. A LDB 9394/96 traz o mesmo princípio no inciso IX, do artigo $3^{\circ}$.

Já no artigo $4^{\circ}$, inciso IX, ela define os padrões mínimos de qualidade de ensino como “a variedade e quantidade mínimas, por aluno, de insumos indispensáveis ao desenvolvimento do processo de ensino-aprendizagem” porém, essa definição apresentada pela LDB/96, não 
foi suficiente, pois ela não quantificou esses insumos ou definiu quais padrões mínimos eles deveriam atender, então:

\begin{abstract}
...se a legislação brasileira incorporou o conceito de qualidade de ensino a partir de Constituição Federal de 1988, essa incorporação não foi suficiente para estabelecer de forma razoavelmente precisa em que consistiria ou quais elementos integrariam o padrão de qualidade do ensino brasileiro, o que dificulta bastante o acionamento da justiça em caso de oferta de ensino com má qualidade. (ARAUJO; OLIVEIRA, 2005, p. 17).
\end{abstract}

Sendo assim, seria necessário que as leis e documentos oficiais estivessem atentos à necessidade de explicitar o que seria, em diferentes momentos históricos, a qualidade na educação e quais mecanismos legais e financeiros deveriam ser utilizados para que ela pudesse ser garantida efetivamente.

Por isso, o objetivo deste capítulo é verificar como o termo qualidade aparece nos documentos oficiais sobre a ampliação do ensino fundamental para nove anos e de que forma ela está sendo garatida no cotidiano escolar, através de investimentos financeiros e pedagógicos, como distribuição de materiais, reformas escolares, formação de professores, número de alunos em sala de aula, jornada de trabalho do professor, entre outros.

Os documentos do MEC sobre a ampliação do ensino fundamental para nove anos previam a melhoria da qualidade da educação com a entrada das crianças de seis anos no ensino fundamental de nove anos. Lê-se, por exemplo, no documento "Ampliação do EF para nove anos - Relatório do Programa" (BRASIL, 2004b) que:

\begin{abstract}
A ampliação em mais um ano de estudo deve produzir um salto na qualidade da educação: inclusão de todas as crianças de seis anos, menor vulnerabilidade a situações de risco, permanência na escola, sucesso no aprendizado e aumento da escolaridade dos alunos. (BRASIL, 2004b, grifos nossos)
\end{abstract}

A esse respeito, Bujes e Marcello (2011), chamam a atenção para a importância de atentar para os desdobramentos do significado de qualidade e sua relação com o conceito de criança, apresentado no documento citado acima:

\footnotetext{
...o rebaixamento etário e a captura pela escolarização obrigatória de crianças já aos seis anos (muitas das quais já frequentando pré-escolas) estariam tanto associados à prevenção dos riscos sociais para esta porção da população infantil, quanto à permanência e à ampliação do tempo de frequência escolar poderiam, adicionalmente, responder por uma trajetório bem-sucedida. Isso se explicaria pela vontade de atingir predominantemente as crianças dos setores populares, aquela vistas sob a égide da vulnerabilidade social. (BUJES; MARCELLO, 2011, p. 62).
} 
O documento do MEC "Ensino Fundamental de nove anos: orientações gerais" (BRASIL, 2004a) tem um capítulo sobre educação com qualidade social, onde discute o avanço do Brasil com relação à democratização do acesso e da permanência no ensino, porém avalia que ainda faltam mudanças efetivas para contrução de uma cidadania solidária, trazendo algumas questões sobre a estrutura espacial, o currículo e a organização do tempo escolar e uma reflexão sobre a importância da discussão com a sociedade para a criação de "um outro conceito de currículo e escola, com novos parâmetros de qualidade." (BRASIL, 2004a, p.11).

Em seguida, o Documento aponta dois aspectos significativos para a construção de uma escola com qualidade social: a escola como pólo irradiador de cultura e conhecimento e o desenvolvimento do aluno como principal referência na organização do tempo e do espaço da escola.

O documento previa, ainda, que: "a adoção de um ensino obrigatório de nove anos iniciando aos seis anos de idade pode contribuir para uma mudança na estrutura e na cultura escolar." (BRASIL, 2004a, p. 17), considerando-se, assim, a nova estrutura do ensino fundamental como potencializadora da melhoria da qualidade social, citada antes, por um movimento de renovação pedagógica. Para Bujes e Marcello (2011):

\footnotetext{
Observa-se, com isso, que, nestes documentos, conceber qualidade é, pois, inseparável de um conceito de criança que deve aprender mais, que deve ter mais oportunidades etc. Não se trata, obviamente, de se contrapor a isso, mas mostrar como se processa o funcionamento de tais dinâmicas. Ou seja, entendemos que nenhum desses conceitos (seja o de qualidade, seja o de criança) existe isoladamente ou mesmo a priori - mas, antes, eles só fazem sentido porque altamente relacionados e em permanente sustentação. ((BUJES; MARCELLO, 2011, p. 62).
}

Além disso, outro ponto destacado, é a importância da reflexão sobre o ensino fundamental como um todo, e não apenas do $1^{\mathrm{o}}$ ano EF9: "Implantar um Ensino Fundamental, agora de nove anos, leva necessariamente a repensá-lo no seu conjunto.” (BRASIL, 2004a, p. 18). A esse respeito, Correa (2007) também entende que:

O momento parece bastante propício para que a atual estrutura e funcionamento da escola de EF, bem como toda sua organização didático-pedagógica, sejam reavaliados de modo a que consigamos garantir o que aqui entendemos por uma completa democratização desse nível de ensino, ou seja, acesso, permanência e qualidade. (CORREA, 2007, p.1, grifos nossos). 
O documento "Ensino Fundamental de nove anos: orientações gerais para a inclusão das crianças de seis anos de idade" (BRASIL, 2006d) trouxe uma preocupação com a efetivação do direito à educação das crianças de seis anos de idade, relacionado à qualidade no ensino:

O direito efetivo à educação das crianças de seis anos não acontecerá somente com a promulgação da Lei $n^{0} 11.274$, dependerá, principalmente, das práticas pedagógicas e de uma política de escola para a verdadeira acolhida dessa faixa etária na instituição (BRASIL, 2006d, p. 30-31).

Em 2009, o MEC publicou o documento "Ensino Fundamental de nove anos: Passo a Passo do Processo de Implantação" (BRASIL, 2009a), e na introdução encontravam-se os objetivos da ampliação do ensino fundamental para nove anos, que seriam:

\footnotetext{
a) melhorar as condições de equidade e de qualidade da Educação Básica;

b) estruturar um novo ensino fundamental para que as crianças prossigam nos estudos,alcançando maior nível de escolaridade;

c) assegurar que, ingressando mais cedo no sistema de ensino, as crianças tenham um tempo mais longo para as aprendizagens da alfabetização e do letramento. (BRASIL, 2009a, p. 5)
}

Novamente, a busca pela melhora da qualidade no ensino aparece como justificativa para a ampliação do ensino fundamental, atrelada, nesse documento, às condições de equidade da Educação Básica, a um maior nível de escolaridade e a um período maior para alfabetização e letramento das crianças. Pode-se perceber, através desses objetivos, a preocupação do MEC com a qualidade do ensino, associada ao processo de alfabetização das crianças, que justificaria a publicação, no mesmo ano, do documento: “A criança de seis anos, a linguagem escrita e o Ensino Fundamental de nove anos: orientações para o trabalho com a linguagem escrita em turmas de crianças de seis anos de idade" (BRASIL, 2009c), focado no processo de alfabetização das crianças de seis anos.

As DCNs do ensino fundamental de nove anos apontam nos parágrafos, $1^{\circ}$ e $2^{\circ}$, do art. $5^{\circ}$, que:

\footnotetext{
$\S 1^{\mathrm{o}}$ O Ensino Fundamental deve comprometer-se com uma educação com qualidade social, igualmente entedida como direito humano.

$\S 2^{\circ}$ A educação de qualidade, como um direito fundamental, é, antes de tudo, relevante, pertinente e equitativa. (BRASIL, 2010a)
}

Através da leitura desses documentos, vê-se que havia uma preocupação por parte dos órgãos oficiais, em garantir e ampliar a qualidade da educação com a nova organização do 
ensino. Em função disso, será analisado a seguir, se as expectativas apresentadas no documentos oficiais foram postas em prática na escola pesquisada.

Para essa análise, Jacomini, Klein e Souza (2009) fazem considerações importantes que devem ser ponderadas quando se discute qualidade do ensino:

\begin{abstract}
Ponderar sobre a qualidade do ensino implica em considerar tanto o currículo escolar, as condições concretas de trabalho das unidades, quanto às formas de participação da comunidade escolar nesse espaço. Esses indicativos para analisar o currículo da escola pressupõe uma concepção de educação que se vincula tanto ao que se faz dentro da escola e, portanto, qual é a formação e as experiências que são propiciadas dentro das unidades educacionais quanto ao como e de que forma isso tem condição de ser realizado. Dessa forma, ao discutir a qualidade da educação pública é necessário estabelecer as condições de funcionamento das escolas que envolvem: os recursos para o financiamento da educação e a estrutura e a organização da escola para a realização do processo educativo. (JACOMINI; SOUZA;KLEIN, 2009, p. 4)
\end{abstract}

Em função destes pressupostos serão analisados, a seguir, os seguintes tópicos: atribuição e formação dos professores do $1^{\circ}$ ano; objetivos; rotina e espaço físico da escola; atividades extra-curriculares; avaliação; implicações para os demais anos do ensino fundamental e opinião dos envolvidos, no município e na escola pesquisada.

\title{
6.2. O ensino fundamental de nove anos e a qualidade da educação no município de São Bernardo do Campo
}

A escola tinha que ter mais desenho, piscina para gente brincar, piscina de bolinha, um pula-pula, um escorregador gigante. (Crianças 1, 3 e 4)

\section{Atribuição e formação dos professores do $1^{\circ}$ ano EF9}

No município de São Bernardo do Campo, a definição dos professores que irão trabalhar com as turmas no ano seguinte é realizada ao final do ano letivo anterior, sendo que ela ocorre por indicação dos diretores das escolas. No documento citado anteriormente: “Orientações para implantação do Ensino Fundamental de 9 anos" (SÃO BERNARDO DO CAMPO, 2010a), da Secretaria de Educação de São Bernardo do Campo, encontravam-se orientações para atribuição das classes de $1^{\circ}$ ano. O Documento afirmava que deveria ser levado em conta: a experiência do professor na educação infantil, as formações que ele possuisse que pudessem estar relacionadas com as necessidades dos alunos dos anos iniciais e que era importante tomar cuidado para não atribuir essas turmas a professores com previsão de licenças prolongadas. Além disso, o Documento orientava que os diretores tivessem uma 
conversa inicial com os professores e pedissem que eles preenchesseem um formulário com dados pessoais, cursos e experiência profissional, para depois escolherem quem seriam os professores dos anos iniciais.

$\mathrm{Na}$ escola pesquisada, durante conversa informal, a diretora afirmou que chamava os professores e perguntava para eles em qual série gostariam de trabalhar, para depois tentar fazer a atribuição da melhor maneira possível, contemplando o desejo do professor com as necessidades das crianças dos anos iniciais. Durante a entrevista, quando perguntada sobre a escolha dos professores que trabalhariam com o $1^{\circ}$ ano EF9 ela afirmou que:

Como eu já estou há bastante tempo aqui na escola, você conhece o perfil dos professores. O perfil que eu identifico é o perfil que ela gosta. As professoras que pegaram o fundamental de nove anos foram aquelas que já estavam no primeiro de oito. Eu acho que fiz uma ótima atribuição. Fizeram um ótimo trabalho. Tanto é que como eu falei no começo tem salas do fundamental de nove que estão melhores que do fundamental de oito anos. Elas brincam muito com essas crianças e as outras não. Para você ver. Pode estar aí a chave, não é? (Diretora, 2010)

Através da fala da diretora pode-se perceber que ela conhecia as professoras da escola e que esteve preocupada em atribuir as turmas de $1^{\circ}$ ano EF9 a professoras que gostassem de trabalhar com crianças pequenas. Porém, é interessante notar que, talvez, essa preocupação não tenha se estendido às outras turmas do ensino fundamental, já que ela afirmou que essas crianças estavam melhores que as da turma do ensino fundamental de oito anos, tema esse que será detalhado posteriormente.

As duas professoras do $1^{\circ}$ ano EF9 da escola pesquisada afirmaram já ter trabalhado com educação infantil, tanto na rede particular como na pública, sendo que uma delas tinha acúmulo de cargo na Prefeitura de São Paulo, onde trabalhava em uma Escola Municipal de Educação Infantil (EMEI). Sobre o trabalho das professoras na educação infantil, a diretora também afirmou que esse foi um dos critérios utilizados para a atribuição das turmas a essas professoras, mostrando estar atenta às orientações da Secretaria Municipal de Educação:

\footnotetext{
As professoras que ficaram com a turma de fundamental de nove anos, principalmente uma de manhã e uma da tarde, em outras redes elas são professoras de educação infantil. Foi um dos critérios de eu ter atribuído a sala, eram professores que vinham do infantil que tinham essa noção de infância. Um professor de quarta série que nunca trabalhou com infantil, vai dar aula expositiva e não combina. (idem)
}

A opção da diretora em atribuir as turmas do $1^{\circ}$ ano EF9 a professoras que já tivessem trabalhado na educação infantil foi importante, justamente por elas conhecerem os aspectos 
relativos aos cuidados e à educação das crianças pequenas, como citado no documento "Ensino Fundamental de Nove Anos - Orientações Gerais":

É essencial que esse professor esteja sintonizado com os aspectos relativos aos cuidados e à educação dessas crianças, seja portador ou esteja receptivo ao conhecimento das diversas dimensões que as constituem no seu aspecto físico, cognitivo-linguístico, emocional, social e afetivo. (BRASIL, 2004a, p. 24).

Com relação à formação das professoras, as duas cursaram Magistério, sendo que a primeira fez Faculdade de Educação Artística, com habilitação em Artes Plásticas e a segunda, a que tinha acúmulo de cargo em São Paulo, cursou Pedagogia. A primeira professora trabalhava com educação há 23 anos, sendo efetiva na rede estadual de São Paulo, porém, em São Bernardo do Campo estava contratada como professora conveniada, devido à municipalização do ensino ocorrida no município. A segunda professora era efetiva na rede municipal há 7 anos e, em São Paulo, há 3 anos.

As duas professoras afirmaram trabalhar com a antiga $1^{\mathrm{a}}$ série há muito tempo, tendo a primeira trabalhado com essa série nos últimos oito anos e a segunda, nos últimos seis anos, tendo realizado esse trabalho juntas, nessa escola, durante todo esse tempo. $\mathrm{O}$ fato das duas terem trabalhado juntas durante todos esses anos foi apontado como um dos fatores pelos quais elas assumiram a sala de $1^{\circ}$ ano EF9:

\footnotetext{
É assim, como a parceria que eu e a outra professora fazemos já tem dado certo há alguns anos e quando a diretora soube da notícia da implementação aqui na escola, ela veio conversou com a gente e a gente abraçou a idéia, por já fazer parcerias em anos anteriores iria facilitar. Porque eu acho que juntou o útil ao agradável, a gente gostar e a diretora confiar no nosso trabalho. (Professora 2, 2010)
}

A outra professora, que escolheu trabalhar com essa turma, afirmou que: "Escolhi porque sou apaixonada por alfabetização, é um trabalho que exige muita dedicação, reflexão e parceria entre colegas e alunos, mas no final o resultado é gratificante.”. (Professora 1, 2010). A partir dessa fala, pode-se afirmar que existia uma relação, que a professora manifestou, entre o $1^{\circ}$ ano EF9 e a alfabetização, mesmo esta não devendo ser o foco do trabalho com essa turma, conforme explicitado nos documentos oficiais. No documento "Ampliação do Ensino Fundamental para nove anos: $3^{\circ}$ relatório do programa", a relativização da prioridade da alfabetização é enfatizada: 
ensino e a aprendizagem dos conteúdos da alfabetização e do letramento, não devem ser priorizadas essas aprendizagens como se fossem a única forma de promover o desenvolvimento das crianças dessa faixa etária. É importante que o trabalho pedagógico implementado possibilite ao aluno o desenvolvimento das diversas expressões e o acesso ao conhecimento nas suas diversas áreas. (BRASIL, 2006c, p. 9).

Com relação à formação dos professores, através da leitura dos documentos oficiais, percebe-se que ela é colocada como uma questão central para a garantia da qualidade no atendimento das crianças de seis anos no ensino fundamental. No documento "Orientações Gerais para a Inclusão das Crianças de 6 anos no Ensino Fundamental”, lê-se que:

\begin{abstract}
A ampliação do ensino fundamental demanda, ainda, providências para o atendimento das necessidades de recursos humanos - professores, gestores e demais profissionais de educação - para lhes assegurar, dentre outras condições, uma política de formação continuada em serviço, o direito ao tempo para o planejamento da prática pedagógica, assim como melhorias em suas carreiras. (BRASIL b, 2006d, p. 8).
\end{abstract}

A Secretária de Educação de São Bernardo do Campo, afirmou, na entrevista, sobre a formação dos professores que, inicialmente, fizeram um levantamento da legislação federal para mandar para as escolas, como o Caderno de Orientações do Ministério da Educação (MEC), que deveria ser discutido nas escolas.

Durante a pesquisa de campo, o único documento entregue às pesquisadoras, pela diretora, além do Documento de "Orientações para implantação do ensino fundamental de nove anos" (SÃO BERNARDO DO CAMPO, 2010a), citado anteriormente, foi um Documento da Secretaria de Educação Municipal, intitulado "Ensino Fundamental de 9 anos”( SÃO BERNARDO DO CAMPO, 2009), que afirmava que seu objetivo era o de "subsidiar as discussões sobre o Ensino Fundamental de 9 anos, tanto nos aspectos históricos de seu surgimento, quanto em relação as legislações que o tem amparado" (SÃO BERNARDO DO CAMPO, 2009, s/p). Para isso, o Documento trazia os seguintes subsídios: "Ensino Fundamental de 9 anos: perguntas mais frequentes e respostas da Secretaria de Educação Básica (SEB/MEC)" e "Educação de qualidade para todos: um assunto de direitos humanos (2007, 2008. Organização das Nações Unidas para a Educação, a Ciência e a Cultura - UNESCO)".

Porém, em nenhum momento, as professoras ou a diretora afirmaram ter lido ou discutido o material. Demonstrando que, muitas vezes, parece faltar tempo ou interesse, para estudo e discussão coletiva sobre as políticas educacionais e suas implicações práticas nas unidades escolares, sendo este um problema a ser enfrentado, pois: 
A freqüência de encontros sistemáticos e coletivos para estudos e proposições permite uma articulação indissociada entre teoria e prática. As experiências revelam que essa estratégia, além de mais bem qualificar o trabalho pedagógico, ainda democratiza as relações intra-escolares, na medida em que oferece oportunidades semelhantes ao grupo de profissionais da escola. (BRASIL, 2004a, p. 26).

Com relação à formação específica dos professores, a Secretária de Educação, durante a entrevista, afirmou que os professores que assumiriam essas turmas teriam uma formação específica, que ocorreria no Centro de Formação de Professores de São Bernardo do Campo (Cenforpe), e que haveria muita orientação na sala de aula por parte dos coordenadores pedagógicos (os dois coordenadores pedagógicos, da escola pesquisada, iniciaram seu trabalho no meio do $1^{\mathrm{o}}$ semestre de 2010, após terem sido aprovados em concurso público e optou-se por não entrevistá-los, por esse motivo). Além disso, ela afirmou que alguns professores da educação infantil foram trabalhar no ensino fundamental:

\begin{abstract}
Inicialmente os professores que assumiriam estas turmas teriam formação específica já na linha de quais seriam os conteúdos que seriam desenvolvidos na qualidade e não na quantidade que eu gostaria porque nós tínhamos pouco tempo, mas para que eles não assumissem simplesmente as turmas e, em algumas escolas foram feitas até trocas de professores, onde alguns alunos da educação infantil perderam professores para o ensino fundamental. Isso aconteceu. (Secretária de Educação de São bernardo do Campo, 2011).
\end{abstract}

Ela afirmou, ainda, que essa formação continuava ocorrendo e que, principalmente o acompanhamento das professoras do $1^{\mathrm{o}}$ ano EF9 era muito mais próximo que o acompanhamento das professoras das outras turmas, já que, por exemplo, no ano de 2011, teria Provinha Brasil ${ }^{16}$ e que, agora, as crianças fariam a prova sendo mais novas. Por meio dessas falas, pode-se perceber, novamente, uma maior preocupação da Secretária de Educação com as turmas do $1^{\circ}$ ano EF9, em detrimento das outras crianças, como as da educação infantil, que "perderam" professores para o ensino fundamental ou das professoras dos outros anos, que não seriam tão acompanhadas como as do $1^{\circ}$ ano EF9.

É importante notar também a preocupação da Secretária de Educação com o desempenho das crianças na Provinha Brasil, conecta-se à tese de Araújo e Oliveira (2005) da associação feita ao termo qualidade do ensino com os resultados das avaliações em larga

\footnotetext{
${ }^{16}$ Segundo o MEC, a Provinha Brasil é uma avaliação diagnóstica aplicada aos alunos matriculados no segundo ano do Ensino Fundamental. A intenção é oferecer aos professores e gestores escolares um instrumento que permita acompanhar, avaliar e melhorar a qualidade da alfabetização e do letramento inicial oferecidos às crianças, para que todas as crianças saibam ler e escrever até os oito anos de idade, uma das metas do Plano de Desenvolvimento da Educação (PDE).
} 
escala: "a ideia de qualidade associada à aferição de desempenho mediante testes em larga escala." (ARAUJO; OLIVEIRA, 2005, p. 8).

Além disso, na escola pesquisada as professoras afirmaram não ter sido informadas sobre nenhum curso de formação, contradizendo a fala da Secretária de Educação, citada anteriormente, sobre a formação oferecida pelo Cenforpe.

Pode-se observar, a partir da pesquisa de campo, que, apesar da importância apontada nos documentos oficiais e na fala da Secretária de Educação sobre a formação dos professores, ela não se efetivou na prática. Marin e Pansini (2011) afirmam a esse respeito que:

\begin{abstract}
Atrelada ao debate sobre a qualidade do EF, a formação docente é outro questionamento realizado com frequencia entre os que discutem a ampliação. Em geral, os documentos elaborados pelo MEC não são omissos em relação a esta necessidade. Paradoxalmente, a formação de professores continua ocorrendo de forma precária, por meio de práticas que pouco contribuem para a elevação dos conhecimentos desse importante grupo de profissionais. (MARIN; PANSINI, 2011, p. 92.)
\end{abstract}

\title{
Proposta Curricular do $1^{\circ}$ ano EF9
}

Sobre o currículo do $1^{\circ}$ ano EF9, o documento do MEC "Ensino Fundamental de Nove Anos - Orientações Gerais" afirma que:

Não se trata de transferir para as crianças os conteúdos e atividades da tradicional primeira série, mas de conceber uma nova estrutura de organização dos conteúdos em um Ensino Fundamental de nove anos, considerando o perfil de seus alunos." (BRASIL, 2004a, p. 17).

Além disso, o documento: “Orientações Gerais para a Inclusão das Crianças de 6 anos no Ensino Fundamental" (BRASIL, 2006d), contém diversos textos sobre a importância do brincar, a pluralidade de linguagens existentes na infância e sobre o processo de alfabetização, orientando o processo de reorganização curricular do $1^{\circ}$ ano EF9, atentando para a importância de estudos e debates e da busca em assegurar o pleno desenvolvimento das crianças:

É preciso que haja, de forma criteriosa, com base em estudos, debates e entendimentos, a reorganização das propostas pedagógicas das secretarias de educação e dos projetos pedagógicos das escolas, de modo que assegurem o pleno desenvolvimento das crianças em seus aspectos físico, psicológico, intelectual, social e cognitivo, tendo em vista alcançar os objetivos do ensino fundamental, sem restringir a aprendizagem das crianças de seis anos de idade à exclusividade da 
alfabetização no primeiro ano do ensino fundamental de nove anos, mas sim ampliando as possibilidades de aprendizagem. (BRASIL, 2006d, p. 9).

Sendo assim, o objetivo deste item é verificar como foi elaborada a proposta curricular para o ensino fundamental de nove anos no município pesquisado, analisando se foram levados em conta os documentos do MEC, quais foram as orientações da Secretaria Municipal de Educação e de que forma a discussão ocorreu na escola.

A Deliberação CMED $n^{0}$ 4/2009 que dispôs sobre a implantação do ensino fundamental de nove anos de duração, no Sistema Municipal de Ensino de São Bernardo do Campo, afirmava que:

\footnotetext{
ASecretaria de Educação e Cultura definirá os objetivos relativos aos conteúdos curriculares, tomando como referência as Diretrizes Curriculares Nacionais" e que "no ano 2010, todas as escolas integrantes do Sistema Municipal de Ensino, que ainda não o fizeram, deverão adequar seu Projeto Político Pedagógico e Regimento Escolar à nova organização da Educação Infantil e do Ensino Fundamental. (SÃO BERNARDO DO CAMPO, 2009b)
}

Porém, como visto anteriormente, os objetivos para o ensino fundamental de nove anos não foram definidos pelos órgãos superiores, em princípio, de forma proposital, cabendo às unidades escolares a construção e definição dos mesmos. Além disso, as próprias DCNs do ensino fundamental de nove anos só foram fixadas em 14 de dezembro de 2010, ano em que o ensino fundamental de nove anos já deveria ter sido implementado em todas as redes de ensino do Brasil.

O documento "Orientações para a implantação do ensino fundamental de 9 anos", da Secretaria Municipal de Educação (SÃO BERNARDO DO CAMPO, 2010a), trazia considerações sobre a proposta curricular para o ensino fundamental de nove anos, explicitando quais documentos deveriam ser referência para a realização do trabalho pedagógico, além de trazer orientações para o planejamento do PPP de 2010:

Para o planejamento do PPP de 2010 cada equipe escolar deverá discutir como a distribuição dos objetivos e conteúdos do ciclo I ocorrerá ao longo dos três anos do Ciclo Inicial, considerando as características da faixa etária dos alunos, a continuidade dos estudos e o grau de aprofundamento que representam. Isto possibilitará às equipes melhores condições para a consideração dos diferentes tempos e necessidades educacionais dos alunos. (SÃO BERNARDO DO CAMPO, 2010a, p. 8)

O documento citava alguns aspectos que deveriam orientar a elaboração da proposta curricular, como a valorização da cultura da infância, através do brincar; o trabalho com 
projetos didáticos; atenção para o trabalho com a oralidade; desenvolvimento do prazer de ler; presença da escrita nas ações cotidianas da escola; desenvolvimento matemático em seus diferentes eixos; vivência de prática sociais corporais; valorização da curiosidade das crianças, entre outros.

Nos documentos da escola, como no PPP, nas Fichas de Rendimento e nas falas das professoras e da direção pode-se analisar com quais objetivos a escola trabalhou no ano de 2010. No PPP da escola, os objetivos gerais para o $1^{\circ}$ ano EF9 definidos, foram:

\begin{abstract}
Assegurar um tempo mais longo de convívio escolar com maiores oportunidades em seus aspectos físico, psicológico, intelectual, social e cognitivo, tendo em vista alcançar os objetivos do ensino fundamental sem restringir a aprendizagem das crianças de seis anos para alfabetização.

Considerando a valorização da cultura da infância e a garantia de momentos de rotina destinados exclusivamente ao brincar e utilizando o diálogo como meio para atingir outros fins, como um objeto de conhecimento que precisa ser aprendidado faz-se necessário a valorização da curiosidade da criança e o incentivo a levantar hipóteses e construir conhecimento em um ambiente propício de integração e interação que possibilitem seu posicionamento crítico na sociedade.

No decorrer do ano, a discussão sobre a implantação do ensino fundamental de nove anos será ampliada mediante as avaliações, em especial nos conselhos de ano/ciclo e os objetivos poderão ser ampliados. (PPP escolar, 2010, grifos nossos)
\end{abstract}

Inicialmente, chama a atenção no texto a preocupação em não restringir a aprendizagem do $1^{\circ}$ ano EF9 à alfabetização e a garantia de momentos exclusivos destinados ao brincar das crianças pequenas. Objetivo este que será melhor analisado nos tópicos de rotina e avaliação, quando será possível perceber se ele foi colocado em prática ou se a alfabetização tornou-se o foco do ensino/aprendizagem das crianças de seis anos, perdendo seus momentos de brincar.

Além disso, é importante destacar que, embora a orientação da Secretaria Municipal de Educação, no Documento citado anteriormente, tenha sido de que a equipe escolar discutisse a distribuição dos objetivos e conteúdos ao longo dos três anos iniciais do Ciclo I do ensino fundamental de nove anos, não foi o que ocorreu na escola pesquisada, pois nela foram definidos apenas os objetivos do $1^{\circ}$ ano EF9.

No final do PPP encontravam-se ainda os objetivos e conteúdos que seriam trabalhados com todos os anos do ensino fundamental, estando os de $1^{\circ}$ ano do EF9 divididos por áreas de conhecimento, sendo elas Língua Portuguesa, Matemática, Ciências, História e Geografia, Artes e Educação Física ${ }^{17}$. A partir dessa divisão, observa-se a proximidade da organização da grade curricular do $1^{\circ}$ ano EF9 com as séries do ensino fundamental e o

\footnotetext{
${ }^{17}$ Os objetivos e conteúdos do $1^{\circ}$ ano EF9 constituem o Anexo A.
} 
distanciamento da educação infantil, pois o brincar e o imaginar, por exemplo, não foram levados em consideração na organização desse currículo, constando apenas nos objetivos gerais citados anteriormente. Além disso, Bianca Correa destaca a importância do artigo 29, da LDB/96, que prevê como finalidade da educação infantil, o "desenvolvimento integral" das crianças, dessa maneira o trabalho educativo nessa fase não pode se dar de maneira fragmentada:

Deve-se ter presente que a criança precisa ser considerada em suas diferentes formas de manifestação, bem como em suas diversas formas de aprender a realidade. Além disso, quanto menor a criança, maiores são suas necessidades de aprendizagem e desenvolvimento, bem como de livre expressão a partir de múltiplas possibilidades. (CORREA, 2007, p. 12).

Sobre a opinião dos envolvidos, a vice diretora disse que ainda estava bastante confusa com relação aos objetivos do $1^{\circ}$ ano EF9, pois para ela, os objetivos desse ano já eram trabalhados pelas professoras na educação infantil. Além disso, é interessante notar em sua fala, a abordagem sobre os objetivos do $1^{\circ}$ ano EF9, como um ano destinado à preparação para alfabetização, pois ela afirmou que:

Eu acredito que é dar um suporte maior para os anos seguintes, mas ainda com esta opinião eu estou em conflito porque isso já acontece na educação infantil, nesse sentido o que tem sido feita é uma preparação para a alfabetização. Pelo fato deles não terem ainda maturidade não podemos cobrar o mesmo que cobramos das crianças da primeira série do fundamental de oito anos. Estou num conflito, preciso ver como eles estarão no ano que vem para saber o que é melhor. Como não tínhamos currículo específico, adaptamos de acordo com o que tínhamos. Qual foi a indicação? Apropriação do alfabeto e da sequência numérica para vermos futuramente o que é possível. (...) Porque ainda não sabemos, tudo é ainda muito confuso, porque estes objetivos já eram trabalhados pelas professoras da educação infantil. (Vice diretora, 2010, grifos nossos)

A partir de sua fala, observa-se, que, apesar dos objetivos propostos no PPP da escola especificarem a preocupação com a valorização da cultura da infância e a garantia do brincar, a própria vice diretora da escola mostrava-se confusa sobre os objetivos e trazia uma visão de educação compensatória, relacionando a educação das crianças de seis anos, tanto na educação infantil como no ensino fundamental, a uma preparação para a alfabetização. Sobre isso, Correa (2011), destaca que:

A questão é o conteúdo que se tem tomado como referência para desenvolver aquilo que está sendo compreendido como preparação. $\mathrm{Na}$ realidade, o que observamos é uma antecipação no sentido de se "fazer antes do tempo", de atividades que mesmo no EF, quando as crianças ai ingressavam com sete anos, já eram consideradas inadequadas (GALVÃO, 2004)" (CORREA, 2011, p. 114). 
As duas professoras entrevistadas afirmaram que não receberam orientação dos órgãos centrais com relação aos objetivos para trabalhar com o $1^{\circ}$ ano EF9 e, apenas uma delas, citou o "Caderno de Orientações" que a Secretaria teria enviado a escola, referindo-se a ele como "uma espécie de livreto informando sobre algumas orientações para a implementação do ensino fundamental de nove anos" (Professora 1, 2010)

Sobre o currículo, elas disseram que, por já terem experiência dos anos anteriores na elaboração do PPP da escola e na confecção do currículo da $1^{\mathrm{a}}$ série, as quatro professoras que trabalhariam com o $1^{\circ}$ ano EF9 elaboraram juntas o currículo, a partir do que já haviam trabalhado com a $1^{\mathrm{a}}$ série EF8, adaptando a rotina com mais brincadeiras, mostrando estarem, mais conscientes da concepção apresentada no PPP da escola, do que a vice diretora. Porém reafirmaram que não receberam nenhum material da Secretaria de Educação:

\begin{abstract}
Então nós não recebemos nada pronto, como eu falei, por ter experiência de anos anteriores e a gente sempre trabalhou na produção do PPP da escola eu e a outra professora. A gente sempre participou das discussões, então assim, facilitou pela experiência que nós tínhamos em criar o nosso currículo, nós da manhã e as duas professoras da tarde, elaboramos juntas este currículo porque não existia nada pronto, não recebemos nada que dissesse nós queremos isso, isso e isso, nós criamos a partir do que tínhamos como experiência de termos já trabalhado com primeira e adaptamos esta rotina das brincadeiras, colocando uma quantidade maior de horas para eles brincarem, mas não veio material, apostila, nada disso. Nós criamos e desenvolvemos durante o ano. (Professora 2, 2010)
\end{abstract}

Assim, pode-se concluir que, apesar da Secretaria Municipal de Educação ter enviado às escolas o documento de Orientações, isto não foi suficiente para responder as dúvidas dos profissionais da escola, mesmo porque, no caso da escola pesquisada, as professoras não tiveram acesso a ele e, tampouco, conversaram com as professoras da educação infantil para organizar um currículo com aspectos importantes desta etapa de ensino. A prática destas professoras poderia ter sido levada em conta, garantindo a continuidade das aprendizagens das crianças, como foi previsto no art. 29, das DCNs do ensino fundamental de nove anos:

Art 29 A necessidade de assegurar aos alunos um percurso contínuo de aprendizagens torna imperativa a articulação de todas as etapas da educação, especialmente do Ensino Fundamental com a Educação Infantil, dos anos iniciais e dos anos finais no interior do Ensino Fundamental, bem como do Ensino Fundamental com o Ensino Médio, garantindo a qualidade da Educação Básica. (BRASIL, 2010a) 
Além disso, os entrevistados se mostraram pouco seguros em relação a quais seriam os objetivos desse ano e com opiniões desencontradas dos objetivos propostos no próprio PPP da escola.

\section{Rotina e espaço físico do $1^{\circ}$ ano EF9}

Por meio da observação semanal da pesquisadora em relação aos espaços escolares e da rotina das crianças, durante os meses de março a novembro de 2010 , pode-se fazer uma descrição e análise dos espaços e momentos vivenciados pelas crianças na escola pesquisada.

De maneira geral, a escola era muito colorida, com bancos e lixeiras formados por diversos lápis de tamanho grande, com quadros coloridos e trabalhos das crianças expostos em murais, nos dois pisos da escola, além da mesma parecer estar sempre muito limpa.

Todos os dias os alunos chegavam à escola às $7 \mathrm{~h} 00$, entravam no pátio coberto e se dirigiam para as filas, divididas por ano, e agrupadas por sexo, meninos de um lado, meninas de outro, prática ainda comum em muitas escolas. Nesse pátio estavam localizadas as duas rampas que conduziam as crianças do piso térreo ao $1^{\mathrm{o}}$ andar, onde ficava a maioria das salas de aula. Uma das rampas era utilizada para subir e a outra para descer e elas possuiam corrimão para as crianças se apoiarem.

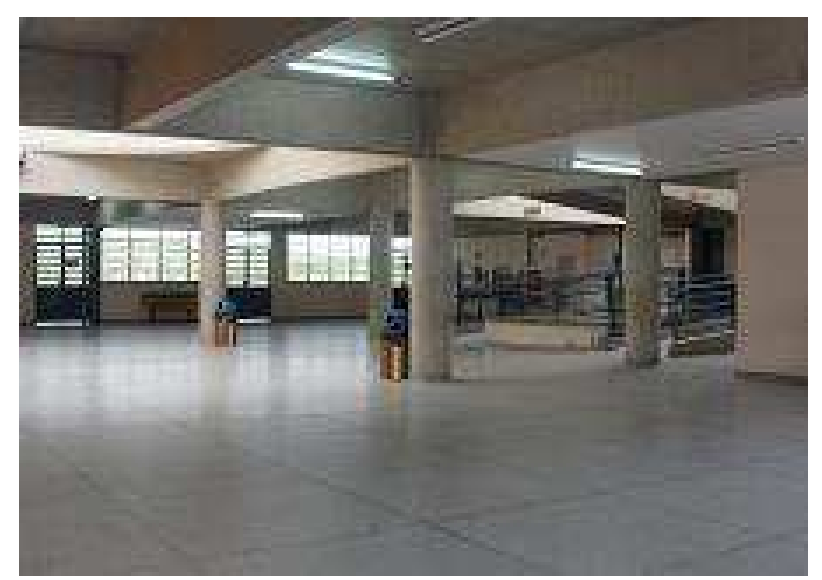

Foto 1: Pátio Interno

Quando as professoras chegavam, todos iam para as salas de aula, com exceção das sextas-feiras, quando todos os alunos da escola permaneciam no pátio para cantar o hino nacional e o hino de São Bernardo do Campo, indo só depois dos cantos para as suas salas. É interessante observar que alguns pais ficavam do lado de fora do pátio, observando pela janela, seus filhos cantando os dois hinos e depois, iam embora. 
No primeiro semestre, as professoras do $1^{\circ}$ ano EF9 e do $1^{\circ}$ ano EF8 aproveitavam esse momento, nas sextas-feiras, para ficar com as crianças mais tempo no pátio, cantando e dançando diversas músicas infantis que uma das professoras do $1^{\circ}$ ano EF9 trazia sempre, pois, conforme afirmou a mesma, já estava acostumada a realizar esse trabalho na EMEI em que trabalhava, no município de São Paulo. As crianças continuavam organizadas em suas filas para cantar e dançar imitando as professoras. Esse momento também ocorria às quartasfeiras e foi possível observar que as crianças pareciam gostar muito, estando alguns dias mais animadas e, outros, menos, assim como as professoras.

Porém, no segundo semestre, pode-se perceber que as professoras acabaram deixando de fazer isso com tanta frequência, pois na sexta-feira, as pesquisadoras não observavam mais esses momentos e, quando perguntadas, as professoras não souberam justificar o motivo.

Essa prátiva demonstra uma preocupação das professoras com a importância de desenvolver diversas linguagens, como a música, para as crianças pequenas, pois a professora trouxe uma prática comum da educação infantil para as crianças do ensino fundamental. As crianças de sete anos, do $1^{\circ}$ ano EF8, também participaram, podendo significar uma melhoria na qualidade do ensino dessas crianças, com a entrada das crianças pequenas no ensino fundamental, como era previsto. Porém, a prática não incluiu todas as turmas do ensino fundamental e também acabou sendo deixada de lado no $2^{\circ}$ semestre, o que indica que essa preocupação ainda não estava consolidada no ambiente escolar.

Depois da entrada, as duas turmas de $1^{\circ}$ anos EF9 iam para suas salas de aula, onde penduravam suas mochilas nas carteiras. As duas turmas de $1^{\circ}$ ano EF9, do período da manhã, dividiam a sala de aula com os dois $1^{\circ}$ anos EF9 que estudavam a tarde. As salas eram compostas de, no máximo, 25 crianças. No início do ano, na sala de aula, as crianças utilizavam mesas e cadeiras como os demais anos do ensino fundamental. Essas mesas estavam organizadas em três fileiras e as crianças sentavam em duplas. Como essas mesas eram as mesmas utilizadas para os demais anos, pode-se observar que, quando sentadas, quase todas as crianças não alcançavam o chão com os pés e ficavam com os pés pendurados na cadeira.

No final do $1^{\mathrm{o}}$ semestre, a escola recebeu novas mesas para as duas salas do Infantil V, então a diretora aproveitou as mesas antigas, que ainda estavam em boas condições de uso, para colocar nas duas salas do $1^{\circ}$ ano EF9. As novas mesas eram mais adequadas para a faixa etária (6 anos) por serem maiores, possibilitando que as crianças sentassem em grupo e por serem mais baixas e com cadeiras menores, mais adequadas ao tamanho das crianças de seis anos. 
É importante observar que, embora os documentos oficiais do Ministério da Educação tenham indicado a necessidade de investimento para adequação do espaço físico da escola e para compra de materiais, como explicitado no documento "Orientações Gerais para a Inclusão das Crianças de 6 anos no Ensino Fundamental”, que afirmava que: "Os espaços educativos, os materiais didáticos, o mobiliário e os equipamentos precisam ser repensados para atender às crianças com essa nova faixa etária no Ensino Fundamental." (BRASIL, 2006d, p. 8), não houve, por parte da Secretaria de Educação do Município, uma preocupação com a compra de mesas e cadeiras novas para as crianças de seis anos, cabendo à diretora da escola planejar e realocar as mesas e cadeiras da escola, quando chegaram outras para as crianças menores.

Porém, as Orientações da Secretaria Municipal de Educação de São Bernardo do Campo, já destacavam a responsabilidade da organização dos espaços para as próprias escolas: "Estas adequações podem implicar na necessidade de alterações nos materiais existentes, como serrar as pernas das cadeiras e mesas, baixar a altura das pias dos banheiros ou construir tablados para que os alunos possam utilizá-las adequadamente, etc." (SÃO BERNARDO DO CAMPO, 2010a, p. 15). Assim, fica clara a posição da Secretaria de Educação de passar a obrigação das adequações físicas para as unidades escolares, mesmo centralizando os recursos financeiros para estas adequações.

Com relação à troca das mesas, as professoras afirmaram concordar com a mudança por ser melhor para as crianças, porém uma delas afirmou que, agora, elas falavam mais e queriam brincar toda hora, pois estavam sentadas em trio e explicou que não foram organizadas em quarteto, para que nenhuma criança ficasse de costas para a lousa e se concentrasse menos na lição. Essa fala indica que, apesar da consciência das professoras sobre as necessidades das crianças pequenas, elas ficavam incomodadas e preocupadas com o aumento das brincadeiras em detrimento da concentração na "hora da lição". A esse respeito, Marin e Pansini (2011), destacam que:

O modelo de ensino adotado com essas crianças não se adaptava a esse mobiliário, pois "o controle das crianças" é dificultado quando estão em grupos, em torno de mesinhas coletivas. $\mathrm{O}$ que nos remete a um ensino no modelo frontal, em que as crianças precisam prestar atenção à professora e ao quadro. (MARIN; PANSINI, 2011, p. 96)

Com relação as brincadeiras das crianças na sala de aula, Correa (2010) afirma que: 
O que observamos durante a permanência em sala de aula foi que as crianças brincam, com ou sem autorização, com ou sem uma organização intencional por parte das professoras. Estas, por sua vez, também percebem esse fato, todavia, não o compreendem integralmente, ora identificando-o como imaturidade, ora como necessidade "natural", mas, em todo o caso, como algo que escapa ao controle e com o que não se sentem inteiramente à vontade para lidar. (CORREA, 2010, p. 6)

Ainda sobre a organização da sala de aula, na frente da sala havia uma lousa bem grande que ocupava quase toda a parede, e em cima dela foi colocado o alfabeto, formado pelos personagens da Turma da Mônica e, logo abaixo, encontravam-se os números de 1 até 100. No lado direito da lousa havia um calendário dos meses, onde as crianças escreveram seus nomes, no mês de seu aniversário. Do lado esquerdo da lousa estava localizada a mesa da professora e ao lado dela havia um armário onde a professora da manhã guardava seu material e o das crianças. A professora da tarde utilizava um armário que existia no fundo da sala, também do lado esquerdo.

$\mathrm{Na}$ lateral esquerda da sala de aula ficavam as janelas e embaixo delas, estavam dispostas algumas mesas enfileiradas, onde as professoras colocavam as pastas de atividades das crianças. Cada criança tinha uma pasta com seu nome, onde elas mesmas guardavam suas atividades quando as professoras solicitavam. Além disso, no final do $1^{\circ}$ semestre de 2010, as professoras receberam blocos de montar para as crianças brincarem, que também foram guardados sobre essas mesas. Esses blocos foram enviados pela Secretaria Municipal de Educação para os $1^{\circ}$ anos EF9, sem ser a pedido da escola, indicando uma preocupação desta com a compra de materiais para as crianças de seis anos.

$\mathrm{Na}$ lateral direita da sala, ao lado da porta, havia um mural onde ficava um relógio de parede, um calendário e alguns cartazes que as professoras iam trocando ao longo do ano. No início da pesquisa de campo havia, por exemplo, um cartaz sobre o sistema solar. Na parede que ficava ao lado desse mural também eram colados cartazes, sendo que no início do ano, como as professoras estavam trabalhando parlendas, havia um cartaz explicando o que era uma parlenda e outro, com a parlenda do suco gelado, que havia sido ensinada às crianças.

A parede do fundo da sala também era utilizada para colar cartazes e atividades das crianças, como um gráfico dos aniversários, construído coletivamente, pelos alunos da manhã. Nessa parede, na parte da direita, encontrava-se também, uma prateleira onde ficavam guardados alguns livros que podiam ser utilizados pelas crianças, porém essa prateleira era alta para o tamanho das crianças do $1^{\circ}$ ano EF9, que precisavam subir em uma cadeira quando queriam pegar os livros. 


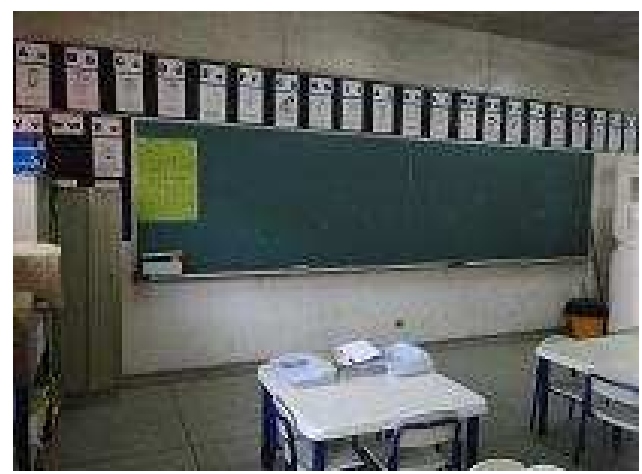

Foto 2: Frente da sala de aula

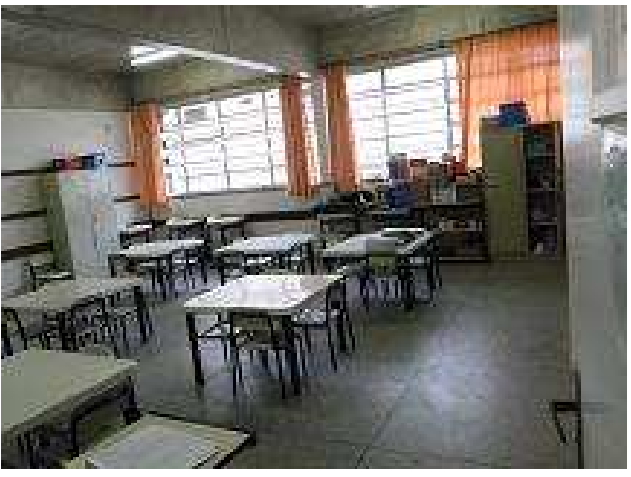

Foto 3: Sala de aula

O documento do MEC "Parâmetros Básicos de Infra-estrutura para as Instituições de Educação Infantill" que apresenta estudos e parâmetros nacionais relacionados à qualidade dos ambientes das instituições de educação infantil, ao tratar da ambientação dos espaços, apresenta questões importantes sobre a adaptação do mobiliário, dos equipamentos e do espaço para as crianças:

\begin{abstract}
A adaptação do mobiliário, dos equipamentos e do próprio espaço à escala da criança permite uma maior autonomia e independência, favorecendo o processo de desenvolvimento a partir de sua interação com o meio físico. Estantes acessíveis, com diversidade de materiais educativos disponíveis, bem como cadeiras e mesas leves que possibilitem o deslocamento pela própria criança, tornam o ambiente mais interativo e coerente à idéia de construção do conhecimento a partir da ação e da intervenção no meio. (BRASIL, 2006e, p. 28).
\end{abstract}

Porém, sobre a disposição da sala de aula, percebeu-se uma preocupação maior com a questão da alfabetização, em detrimento do brincar e da autonomia das crianças, já que se encontravam, predominantemente, cartazes relacionados ao sistema de escrita e numérico, enquanto os livros não estavam ao alcance das crianças e não havia brinquedos ou outros materiais, apenas blocos de montar, que chegaram apenas no final do $1^{\circ}$ semestre.

Sobre essa questão, o documento do MEC "Ensino Fundamental de Nove Anos Orientações Gerais", enfatizava a importância da criação de um ambiente alfabetizador, tomando cuidado, porém, para que este não seja o único aspecto focado no $1^{\circ}$ ano EF9:

Será necessário, por parte dela, um grande investimento na criação de um ambiente alfabetizador, que possibilite às crianças não apenas ter acesso ao mundo letrado, como também nele interagir. É importante ressaltar, no entanto, que a alfabetização não pode ser o aspecto único nem tampouco isolado desse momento da escolaridade formal. (BRASIL, 2004a, p. 22). 
Depois das crianças guardarem as mochilas, em uma das salas, a professora rezava "O Pai Nosso" com elas, outra prática comum em algumas salas de aula brasileiras, apesar da laicidade do Estado e das escolas públicas, prevista na Constituição Federal de 1988.

Após esse momento, as professoras das duas salas do $1^{\circ}$ ano EF9 seguiam para o pátio externo, onde ficava o parque, para as crianças brincarem livremente, por meia hora, todos os dias. Esse pátio ficava do lado de fora do prédio e era bem grande, sendo uma parte cimentada e a outra com areia, onde havia um parque com balanços, um gira-gira e um trepa-trepa - que não estavam em boas condições - uma vez que o gira-gira havia quebrado no meio do ano e permaneceu em conserto até o final do ano. A conservação da área externa das escolas era fundamental para o desenvolvimento das crianças pequenas pois, como afirma o "Referencial Curricular Nacional para a Educação Infantil”:

\footnotetext{
"Na área externa, há que se criar espaços lúdicos que sejam alternativos e permitam que as crianças corram, balancem, subam, desçam e escalem ambientes diferenciados, pendurem-se, escorreguem, rolem, joguem bola, brinquem com água e areia, escondam-se, etc." (BRASIL 1998, p. 69)
}

$\mathrm{Na}$ hora do parque as crianças pegavam alguns brinquedos que existiam na escola ou que as professoras guardavam e, nas sextas feiras, podiam trazer brinquedos de casa, pois esse era conhecido como o "dia do brinquedo".

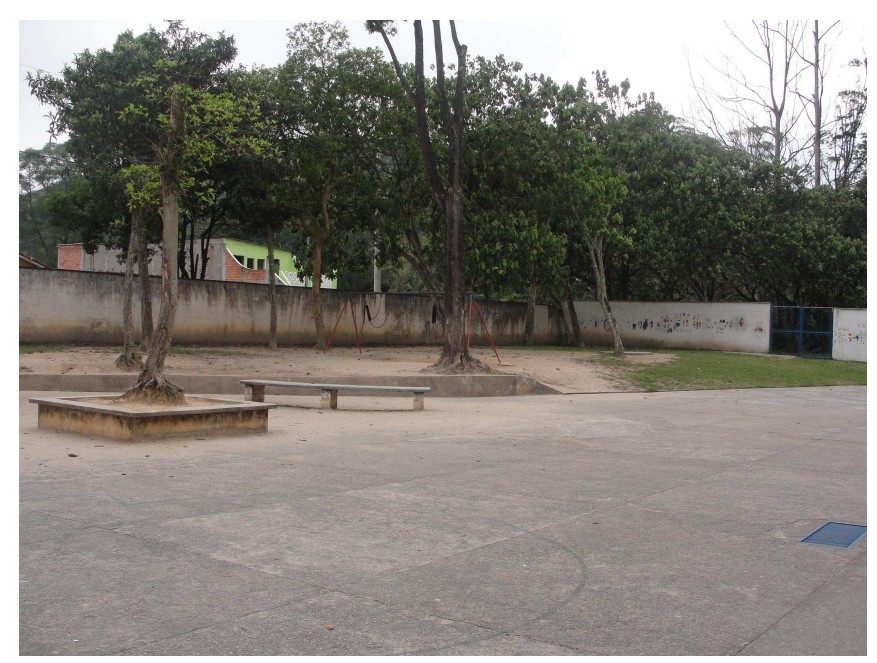

Foto 4: Pátio externo

É importante notar que, assim como os momentos de música diminuiram no $2^{\circ}$ semestre, o mesmo aconteceu com o parque, pois se observou que as crianças não tinham mais esse período, em todos os dias da semana, já que, em alguns dias, elas já subiam para a 
sala e começavam a aula normalmente, demonstrando que a preocupação com o brincar foi diminuindo ao longo do ano, tornando-se o $1^{\mathrm{o}}$ ano EF9 mais próximo da antiga $1^{\mathrm{a}}$ série, com o passar do tempo.

Após o parque, quando voltavam para a sala de aula, as crianças recebiam seus cadernos, que ficavam guardados na escola, sendo levados para casa apenas nas sextas-feiras, para que seu pais pudessem acompanhar o que eles tinham trabalhado. Copiavam o cabeçário (nome da escola e a data) todos os dias e mais a rotina do dia da lousa, que ia sendo completada conforme eles realizavam as atividades. Algumas crianças demonstravam ter muita dificuldade nesse momento, não sabendo direito onde tinham que escrever, demorando muito para copiar da lousa e preferindo brincar ou conversar ao invés de fazer a cópia. Quando isso acontecia, a professora chamava a atenção das crianças ou mudava elas de lugar. $\mathrm{Na}$ turma acompanhada pela pesquisadora havia um menino que sempre tinha dificuldade para realizar essa cópia no caderno, sendo colocado, em muitos dias observados, numa mesa separada ao lado da professora até concluir a atividade.

Normalmente, após a cópia da rotina, as professoras faziam, nesse momento, alguma atividade relacionada à alfabetização ou à matemática, pois afirmaram que, no início do dia, as crianças estavam mais calmas e tinham mais facilidade para se concentrarem na lição.

Às $9 \mathrm{~h} 15$, as crianças do $1^{\mathrm{o}}$ ano EF9 e do $1^{\circ}$ ano EF8 desciam juntas para o refeitório, onde era servido um almoço com sistema self service. Como as crianças realizavam apenas uma refeição na escola, recebiam um almoço, ao invés de lanche, por ser considerado mais nutritivo para as crianças provenientes de classes sociais mais carentes. No almoço, era servido arroz e feijão, algum tipo de carne e salada ou fruta. As crianças se serviam em fila e sentavam para comer em mesas e bancos. Algumas crianças costumavam trazer lanche de casa, o que trazia alguns problemas, de acordo com a professora, pois as outras crianças ficavam com vontade de comer o lanche do colega e acabavam não querendo comer a comida da escola.

Depois de comer, todos iam ao parque brincar por, aproximadamente, vinte minutos e, em dias de chuva, elas faziam o recreio no pátio coberto que ficava próximo ao refeitório. Nesse interim, as professoras aproveitavam para conversar, trocar alguma ideia de atividade ou resolver algum problema que precisassem, mesmo estando no parque junto com as crianças, pois em São Bernardo do Campo não havia tempo previsto para o descanso das professoras de nenhuma das turmas. As crianças eram acompanhadas por um inspetor de alunos que costumava ficar batendo corda para as crianças pularem, outras brincavam com brinquedos trazidos de casa, ficavam no parque ou correndo com os colegas. Depois do 
recreio, elas iam ao banheiro lavar as mãos e escovar os dentes, antes de voltarem para as salas de aula.

Os banheiros eram um grande problema, apontado principalmente pelas professoras, pois não havia nenhum banheiro adaptado para as crianças menores, que tinham que subir em um tablado feito de madeira para alcançar a pia, para lavar as mãos ou para escovar os dentes. A esse respeito a diretora afirmou, durante a entrevista realizada no final do ano, que: "Não gosto daquele tablado, porque acho ele perigoso. Foi apenas um improviso, tanto é que só coloquei no banheiro. Inclusive hoje, à tarde, virá uma pessoa para rebaixar duas daquelas pias." (Diretora, 2010).

$\mathrm{Na}$ sala de aula, todos os dias a professora realizava uma leitura, com as crianças sentadas na frente da sala e em alguns momentos, também fazia rodas de conversa para trabalhar alguma tema específico, aspecto importante da rotina, constante do Documento encaminhado pela Secretaria Municipal de Educação às escolas:

\begin{abstract}
A roda pode ser um momento privilegiado para o trabalho com a oralidade. Esse momento pode ser organizado pelo professor, com propostas que tenham como objetivo diversificar as possibilidades de utilização de diferentes gêneros orais. (...) Alé disso, a roda permite que os alunos se vejam uns aos outros, favorece a atenção, a concentração e o revezamento das falas. É uma configuração especial para que aconteçam intercâmbios por meio da oralidade e para que se exercitem tanto a fala quanto a escuta. (SÃO BERNARDO DO CAMPO, 2010a, p. 12)
\end{abstract}

Após a leitura, voltavam a fazer as atividades. Um exemplo de atividade observada foi feita com base no poema "As Borboletas", de Vinícius de Moraes. Inicialmente foi feita a leitura do poema pela professora, depois ela chamou as crianças para fazerem a leitura do livro "Lagarta na primavera, borboleta no verão", e conversou sobre a transformação ocorrida com a lagarta e sobre as rimas que apareciam na história. Depois voltaram aos seus lugares e junto com a professora releram o poema. Ou seja, a professora lia e as crianças repetiam, e foram feitas perguntas sobre quais cores apareciam nele, para depois a professora solicitar que circulassem as cores no poema. Alguns alunos mostraram grande dificuldade para realizar essa atividade, sendo ajudados pela professora. Depois receberam uma folha com uma borboleta para pintar, recortar e montar num palito de sorvete e, quem fosse terminando, poderia ficar brincando pela sala com a borboleta.

Durante a pesquisa de campo foi observado que, normalmente, as professoras tentavam fazer atividades da linguagem escrita ou matemática, associadas a pinturas, colagens, leituras, músicas, filmes e até confecção de uma salada de frutas com as crianças, 
entre outras alternativas, mostrando uma tentativa de não ficarem tão presas a atividades apenas de escrita e leitura no papel:

\begin{abstract}
Nós fomos pensando, no decorrer do ano, em atividades como culinária, atividades que eles pudessem fugir da rotina que a gente sabe que o fundamental tem. Em artes, com o projeto do Romero Britto, agora deu esta luz no segundo semestre, eles estão empolgados, o material que eles estão produzindo são materiais que mostram que eles gostaram que se adaptaram ao que a gente propôs para eles. Então assim, a gente tentou, dentro da nossa rotina, passar atividades e conteúdos de modo que eles fossem dar conta, mas pensando num trabalho mais interdisciplinar, nada muito fechado. (Professora 2, 2010)
\end{abstract}

Porém, pode-se observar que a preocupação com a alfabetização estava sempre presente, sendo constantemente o objetivo maior destas atividades, como se percebeu na fala das próprias professoras: “A gente acaba caindo na alfabetização, dizer que eles são obrigados a estar alfabetizados no primeiro ano, não. Eles terão três anos para ter esta base, só que como nós já tínhamos a experiência anterior a gente não consegue fugir disso" (Professora 2, 2010)

Outro exemplo disso foi a realização bimestral das "sondagens de escrita"18 atividade esta inserida na rotina de toda escola e realizada pelas professoras, para que elas soubessem em qual "hipótese de escrita" as crianças se encontravam. Estas hipóteses eram anotadas em folha específica e enviadas para a Secretaria de Educação. Com relação às sondagens é interessante observar que uma criança que participou da entrevista com as pesquisadoras, acabou desenhando a "mesa de sondagem" da professora (consistia em uma mesa e uma cadeira colocada ao lado da mesa da professora para que ela pudesse fazer o ditado, individualmente, com cada criança) quando foi pedido que eles desenhassem como era sua escola. Pode-se perceber o quanto essa prática está inserida no cotidiano das crianças:

\footnotetext{
${ }^{18}$ A sondagem de escrita é utilizada para identificar quais hipóteses as crianças tem acerca do funcionamento da lingua. Essas hipóteses são: fase Pré-silábica, silábica (com ou sem valor), silábica-alfabética e alfabética, em tese, traduzindo as propostas metodológicas do sócio-construtivismo.
} 


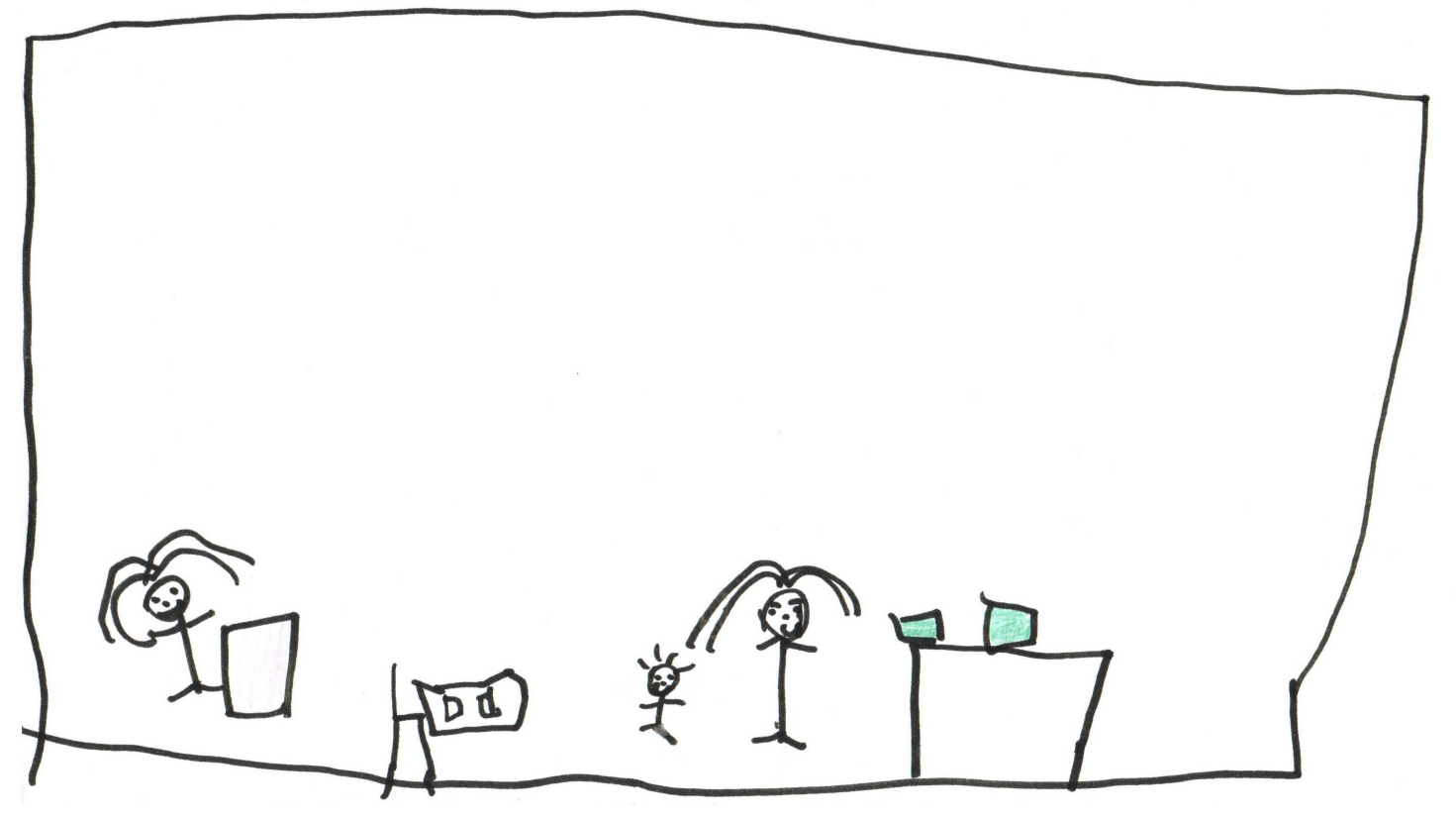

Desenho 1: Mesa de sondagem

A esse respeito, Correa (2010), afirma que:

\begin{abstract}
Vale ressaltar o quanto essas "sondagens" se tornaram processos mecânicos que, sem um conhecimento profundo sobre a própria teoria que embasa essa prática, acaba se tornando, no mais das vezes, um instrumento de mera classificação dos alunos, sem resultados práticos que os façam aprender, de fato, a ler e a escrever. (CORREA, 2010, p. 14)
\end{abstract}

O documento "A criança de seis anos, a linguagem escrita e o Ensino Fundamental de nove anos: orientações para o trabalho com a linguagem escrita em turmas de crianças de seis anos de idade." (BRASIL, 2009a) estava dividido em três partes, sendo que a primeira fazia uma discussão sobre o ensino e a aprendizagem da linguagem escrita das crianças menores de sete anos de idade. A segunda parte trazia diversos textos que discutiam fundamentos teóricos e propostas pedagógicas de algumas dimensões do processo de alfabetização das crianças. A terceira apresentava um diálogo com as práticas pedagógicas de alfabetização e letramentos das crianças de seis anos e, por fim, trazia as Considerações Finais.

Esse documento, diferente das "Orientações para a Inclusão das crianças de seis anos de idade" (BRASIL, 2006d), que além de apresentar textos sobre alfabetização, trazia diversos textos sobre a importância do trabalho com as diferentes linguagens, do brincar e do lúdico, mostra o foco do MEC na importância do processo de alfabetização iniciar-se mais cedo, preocupação esta compartilhada pelas professoras. 
Quando eles terminavam as atividades, brincavam com massinha, com algum brinquedo que tivessem trazido de casa, com alguns brinquedos que tivessem confeccionado na aula ou com os livros expostos na sala. Com relação a esses livros cabe ressaltar que a orientação da Secretaria Municipal de Educação era que:

\footnotetext{
Este material deve estar preferencialmente exposto permanentemente configurando um "cantinho da leitura" de maneira atrativa. É importante que o professor utilize esse kit não apenas como alternativa aos momentos de espera, mas atividade permanente dentro de um trabalho intencional do professor. (SÃO BERNARDO DO CAMPO, 2010a, p. 14)
}

Apesar de ser essa a orientação da Secretaria Municipal de Educação, durante a pesquisa de campo, observou-se a utilização dos livros apenas como momento de espera entre uma atividade e outra, ou para esperar os pais chegaram para buscá-los, não havendo, um trabalho intencional com eles. Além disso, como citado anteriormente, os livros não estavam ao alcande das crianças, que precisavam subir em uma cadeira para os pegar.

No final do dia, enquanto as crianças que já haviam terminado suas tarefas ficavam brincando livremente na sala de aula, a professora orientava que, nos dias que não tivessem escovado os dentes após o recreio, escovassem naquele momento, antes de ir para casa. Depois, os pais buscavam os alunos na sala de aula, onde podiam aproveitar para conversar com a professora e conhecer os amigos de seus filhos.

Em alguns dias, as crianças recebiam uma folha de lição de casa, que deviam guardar em uma pasta que ganharam no início do ano e entregar para a professora, no dia seguinte. Normalmente eram atividades simples, como pintar os objetos de higiene que apareciam em uma folha ou ler pequenas tiras de quadrinhos da "Turma da Mônica". Algumas crianças gostavam de levar lição para fazer em casa, porém outras reclamavam. Em um dia de observação da rotina, por exemplo, antes de começar a aula, quando os alunos ainda estavam em fila, uma menina disse que "levou uma lição de casa muito chata de circular, pintar e ler". (Caderno de Campo, março de 2010).

Com relação ao material escolar que as crianças utilizavam, no Livro de Registro das Reuniões de HTPC, no mês de março, houve a discussão sobre o material escolar recebido da Prefeitura, que é diferenciado para a educação infantil e para os dois ciclos dos anos iniciais do ensino fundamental em que estava organizada a rede de ensino de São Bernardo. O material podia ser distribuido aos alunos, a critério da escola, podendo as professoras guardarem uma parte do material na escola e enviar para casa do aluno, apenas o que considerassem adequado. 
O material do $1^{\circ}$ ano do EF9 foi composto de massinha, lápis grafite jumbo (que é um lápis grafite mais grosso, adaptado às mãos das crianças pequenas), lápis de cor, canetinha (piloto e normal), giz de cera, régua, cola, estojo, borracha, apontador, tinta aquarela, pincel, 5 (cinco) cadernos brochura, um caderno de desenho, uma pasta grande, uma pasta com elástico, uma pasta com plásticos e uma mochila. A composição do material demonstra que a Prefeitura Municipal estava preocupada com as diferentes idades dos alunos, pois as crianças pequenas, por exemplo, recebiam um lápis mais adequado a sua idade (o lápis grafite jumbo), além da massinha, material normalmente utilizado na educação infantil. Apesar disso, a preocupação com a alfabetização pode ser notada, com a distribuição de cinco cadernos brochura para o $1^{\circ}$ ano EF9.

Além das atividades em sala de aula, uma vez por semana as crianças de cada turma da escola tinham aula de informática com uma professora designada, mas onde também eram acompanhadas pela professora da sala. O laboratório de informática aparentava estar bem conservado e era formado por 4 (quatro) balcões compridos onde ficavam os computadores e as crianças sentavam em duplas. As atividades desenvolvidas nessas aulas eram planejadas pela professora de informática, de acordo com o planejamento de cada ano.

As crianças tinham, também, uma aula de educação física por semana, que era dada pela professora da sala. Ela era realizada na quadra coberta, que ficava ao lado do pátio externo. A quadra também tinha uma arquibancada de três andares que comportava cerca de cem crianças sentadas. As professoras do $1^{\mathrm{o}}$ ano EF9 acabavam realizando essas aulas juntas, pois afirmaram em conversa informal, que acreditavam ser importante que as crianças tivessem mais tempo nesse espaço, sendo assim, se as duas fossem juntas, as crianças poderiam ter duas aulas, ao invés de apenas uma. Outro motivo dado foi que, como elas seguiam o mesmo planejamento, preferiam trabalhar sempre juntas.

Nessas aulas elas costumavam realizar brincadeiras e jogos com as crianças, além de fazer percursos e circuitos e, para essas atividades utilizavam bolas, bambolês, cordas, entre outros materiais. Além disso, alguns dias separavam as crianças, ficando algumas brincando no parque enquanto outras faziam a atividade na quadra, para depois trocar, pois assim realizariam a atividade com um número menor de crianças por vez.

A aula de artes era realizada na sala de aula ou no ateliê de artes. Ele ficava em frente ao laboratório de informática e era formado por mesas grandes com bancos presos ao chão que ficavam em volta das mesas e contava com uma estante, onde as professoras guardavam materiais como tintas, canetinhas, papéis, entre outros. Assim como as aulas de educação 
física, estas aulas aconteciam uma vez por semana e eram dadas pelas professoras de sala, pois o Município não conta com professor especialista dessas disciplinas.

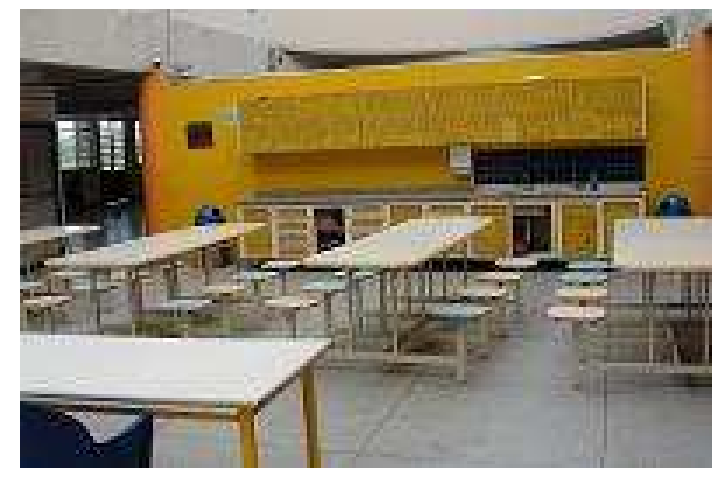

Foto 5: Ateliê de artes

Uma vez por semana, também, podiam usar a biblioteca, acompanhadas pelas professoras, porém, assim como as aulas de educação física, as duas professoras do $1^{\circ}$ ano EF9, normalmente utilizavam juntas o espaço para terem duas aulas lá.

A biblioteca era grande, com várias prateleiras baixas em volta das paredes, onde as crianças conseguiam alcançar os livros que eram para sua faixa etária. A sala possuía diversas mesas que podiam se juntar facilmente, pois tinham rodinhas nos pés, possibilitando várias formações entre elas e eram de dois tamanhos distintos, sendo algumas maiores e outras menores. Além disso, no fundo da sala da biblioteca havia um espaço com aparelhos de rádio e televisão onde as crianças podiam se sentar em cima de almofadas no chão para assistirem filmes, ou ainda, em uma mini arquibancada, possibilitando que o espaço fosse utilizado também para apresentações de trabalhos das crianças, como o ensaio de uma peça que as crianças do $1^{\circ}$ ano EF9 apresentaram no "Dia da Família", que será descrito posteriormente.

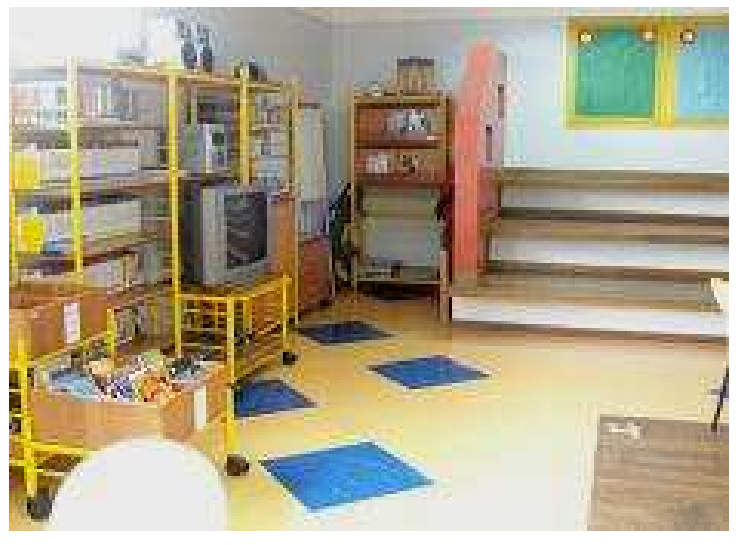

Foto 6: Fundo da Sala da Biblioteca

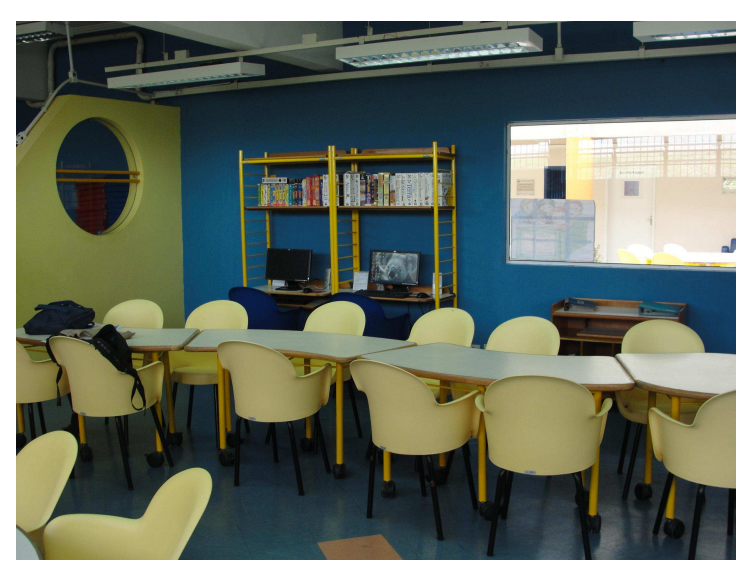

Foto 7: Biblioteca 
Durante a Gestão Municipal anterior, havia na biblioteca um professor de Sala de Leitura, função esta que era ocupada anteriormente, pela atual vice-diretora da escola, porém com a mudança de Gestão, em 2009, essa função foi substituída por uma bibliotecária que organizava os livros e auxiliava as professoras quando elas precisavam encontrar algum livro ou material específico, porém ela não realizava nenhum trabalho com as crianças, como de contadora de histórias, por exemplo.

Além desses espaços, no segundo semestre, foi criada uma brinquedoteca em uma sala que ficava no piso térreo. Ela foi montada com diversos brinquedos enviados pela Secretaria Municipal de Educação, tais como: jogos de montar, quebra-cabeças, carrinhos, bonecas, boliche, telefones, casinhas, entre outros. Esse espaço passou a ser utilizado pelas turmas do $1^{\circ}$ ano EF9, além das turmas do Infantil $\mathrm{V}$ e do $1^{\circ}$ ano EF8, que organizaram um horário coletivamente, possibilitando que todas as turmas fossem à brinquedoteca, diariamente.

Porém, apesar de poderem ir todos os dias à brinquedoteca, as professoras do $1^{\mathrm{o}}$ ano EF9 disseram que elas costumavam ir a brinquedoteca três dias por semana, quando as crianças não haviam tido educação física ou parque, porque, nesses dias, elas não tinham muito tempo para brincar ou, no final de muitas aulas, quando elas percebiam que os alunos já estavam cansados e não se concentrariam mais nas atividades de sala de aula. Com isso, podese perceber a cisão que existia para as professoras entre o brincar e o aprender, pois a brinquedoteca era vista como momento de diversão, de gastar energia, de não concentração e não como ambiente de aprendizagens.

A importância do brincar é destacada no texto "O Brincar Como um Modo de Ser e Estar no Mundo" da Ângela Meyer Borba, que faz parte do documento "Orientações Gerais para a Inclusão das Crianças de 6 anos no Ensino Fundamental”. Nele, a autora destaca que:

\footnotetext{
Podemos afirmar que o brincar é um espaço de apropriação e constituição pelas crianças de conhecimentos e habilidades no âmbito da linguagem, da cognição, dos valores e da sociabilidade. E que esses conhecimentos se tecem nas narrativas do dia-a-dia, constituindo os sujeitos e a base para muitas aprendizagens e situações em que são necessários o distanciamento da realidade cotidiana, o pensar sobre o mundo e o interpretá-lo de novas formas, bem como o desenvolvimento conjunto de ações coordenadas em torno de um fio condutor comum. (BRASIL, 2006d, p. $39)$.
}

Por fim, um aspecto importante quando se fala de infra-estrutura e do uso dos espaços na rotina escolar, apresentado no documento acima mencionado, é considerar o uso que se faz do espaço, pois não adiantaria a escola ter a infra-estrutura, como no caso da brinquedoteca criada na escola pesquisada, mas não a utilizar de forma apropriada: 
A estética dos espaços e as relações que se estabelecem revelam o que pensamos sobre crianças e educação. Essas concepções estão presentes em todas as práticas existentes no interior da escola, deixando mais ou menos explícitos os valores e conceitos dessa instituição.(idem, p. 28).

\section{Atividades extracurriculares}

Durante o ano letivo, na escola pesquisada, ocorreram algumas atividades consideradas extracurriculares, como festas, exposições e passeios, que passam a ser explicitadas e analisadas.

Foi realizado na escola, no mês de maio, o "Dia da Família", dia este, em que os pais foram até a escola para participar de oficinas e assistir a apresentações feitas por seus filhos. As professoras dos dois $1^{\mathrm{o}}$ anos do EF9 optaram por apresentar uma peça com a história da “Arca de Noé” encenada por todos os alunos das duas salas. As pesquisadoras puderam

acompanhar alguns ensaios, que aconteceram na Biblioteca, onde também ocorreu a apresentação. As crianças estavam divididas entre o Noé e sua família, os animais que vão para a arca e a chuva. Havia uma fita que narrava e as crianças iam encenando a história. No final elas cantavam uma música sobre a chuva e outra, sobre a Arca do Noé.

Durante os ensaios pode-se observar que algumas crianças estavam bem animadas por participar da peça, enquanto outras pareciam cansadas, pois os ensaios chegavam a durar mais de uma hora em alguns dias, principalmente na semana da apresentação. Durante um ensaio, pode-se observar que as crianças não puderam ir ao banheiro e nem tomar água, pois as professoras pareciam bem focadas em garantir que a apresentação ficasse boa, demonstrando uma preocupação maior com o resultado e a opinião dos espectadores, do que com o processo de experimentação da linguagem teatral das crianças e suas opiniões sobre a apresentação.

No dia da apresentação, os alunos que representariam animais usavam máscaras dos bichos e as crianças que representariam a chuva utilizavam pompons azuis. As professoras disseram estar preocupadas com o número de crianças que iriam estar presentes na apresentação, por ser em um sábado, mas contaram que, no dia, deu tudo certo, pois poucas crianças faltaram e os pais gostaram da representação.

No $1^{\circ}$ semestre houve também um passeio envolvendo todos os alunos da escola para assistir à peça de teatro: “Alice no País das Maravilhas". Esse passeio foi organizado pelo Cenforpe e as professoras do $1^{\circ}$ ano EF9 disseram que as crianças gostaram muito de ir, mas que não entederam muito bem a peça, pois ela não era adequada a essa faixa etária, mas, por 
sairem da escola, andarem de ônibus e tomarem lanche, as crianças se mostraram bastante animadas.

Para o $2^{\circ}$ semestre, as professoras planejaram uma ida ao Aquário, na cidade de Santos, onde elas já haviam estado em anos anteriores, com outras turmas. Antes de irem ao Aquário, elas começaram a trabalhar com as crianças os animais marinhos, lendo livros, assistindo filmes como "Procurando Nemo", que também mostrava diversos animais marinhos, fazendo fichas dos animais, mostrando imagens, fazendo desenhos com as crianças, além de outras atividades. Percebe-se que este passeio foi melhor organizado que o anterior, pois a ideia de ir ao Aquário veio das professoras que estavam realizando um projeto com as crianças sobre os animais marinhos, que culminou na visita, diferentemente do anterior, pois o teatro havia sido indicado pelo CENFORPE e não era adequado para a faixa etária das crianças de seis anos, como as professoras afirmaram anteriormente.

Um aspecto importante da visita ao Aquário foi a preocupação, que as professoras disseram ter, com a atitude da diretora da escola, que não queria que as crianças pisassem na areia em Santos, nem para brincar em um parquinho que havia na areia, próximo ao Aquário e que, em anos anteriores, as professoras disseram ter permitido que as crianças brincassem um pouco. Ela achava que era perigoso, pois as crianças poderiam se machucar ou se perder. Por isso, as professoras estavam muito incomodadas em não deixarem as crianças irem à praia já que estavam em uma cidade litorânea, como Santos, pois diziam que muitas crianças nunca tinham visto o mar, então estavam bem animadas com o passeio, porém a diretora proibiu que elas fossem ao parquinho.

Porém, após a visita, durante uma conversa informal com as pesquisadoras, as professoras contaram que as crianças gostaram muito do passeio, ficaram muito animadas por conhecerem tantos animais no Aquário e que, após a visita, foram lanchar em frente à praia, em bancos que estavam localizados próximos ao Aquário. Disseram que haviam alguns jogadores juniores do time de futebol "Santos Futebol Clube" treinando na areia, e que eles começaram a conversar com as crianças e insistiram para que elas deixassem as crianças brincar na areia. A coordenadora que acompanhava o passeio disse que "não estava vendo nada" e autorizou que as crianças fossem brincar na areia com os jogadores, por dez minutos, apenas. Na volta à escola, elas contaram que o ônibus chegou muito atrasado, pois afirmaram que o motorista se perdeu na volta, já que o mesmo veio por Cubatão, mas, que o mesmo disse que se atrasaram porque as professoras permitiram que as crianças brincassem na areia, deixando a diretora brava, pois haviam desobedecido sua ordem. Por causa desse fato, as crianças do período da tarde, que também foram ao passeio, no mesmo dia, foram 
acompanhados pelo outro coordenador, que não permitiu sequer que as crianças lanchassem em Santos, sendo obrigadas a comer no ônibus, na volta para escola.

Dois pontos chamaram a atenção nesse evento, primeiro, a tomada de decisão centralizadora da diretora da escola, que não levou em consideração a opinião das professoras sobre o perigo ou não, que representaria o fato das crianças brincarem no parquinho ou na areia de Santos e, o segundo, da preocupação excessiva dela, que impediu a oportunidade das crianças pequenas brincarem em um espaço distinto do escolar, experiência esta que poderia ter sido enriquecedora para elas.

Nos dias seguintes ao passeio, as professoras continuaram trabalhando os animais marinhos, fazendo um fechamento com as crianças do que eles haviam visto no Aquário e confeccionando uma massinha com as crianças, para que cada uma escolhesse um animal para montar.

No $2^{\circ}$ semestre foi comemorado na escola o "Dia das Crianças", sendo que a comemoração durou a semana toda para os $1^{\circ}$ anos do EF9 que, a pedido da direção da escola, tiveram uma semana mais lúdica, com mais tempo para brincar livremente e com atividades em sala de aula e em outros espaços diferenciadas. A semana culminou na contratação, pela APM da escola, de brinquedos como pula-pula, cama-elástica e escorregador de ar para que todas as crianças da escola pudessem passar o dia brincando. É interessante notar, mais uma vez, a preocupação colocada pela diretora com os $1^{\circ}$ anos EF9, que não foi compartilhada com os demais anos, o que demonstra clara fragmentação do ensino fundamental.

No final do $2^{\circ}$ semestre foi realizada uma mostra cultural, no mês de novembro, que contou com diversas exposições feitas pelos alunos e professores de toda a escola. Os $1^{\circ}$ anos do EF9 realizaram um trabalho sobre o pintor Romero Britto, e as professoras trouxeram diversas obras do autor para as crianças, analisando os pontos em comum, as formas geométricas trabalhadas por ele, as cores em suas obras e levaram alguns produtos cuja embalagem ou slogan tivesse sido criado pelo pintor, além de pintarem e desenharem eles mesmos, algumas obras. Para a exposição foram escolhidas algumas dessas obras pintadas em tela pelas crianças, para serem expostas junto com um boneco feito por uma das professoras e pintado coletivamente pelos alunos das duas salas, que reproduzia uma das principais obras do pintor. 


\section{Avaliação da Aprendizagem}

A LDB/96, em seu artigo 31, afirma que: "Na Educação Infantil a avaliação far-se-á mediante acompanhamento e registro do seu desenvolvimento, sem o objetivo de promoção, mesmo para o acesso ao Ensino Fundamental.”. Os documentos do MEC sobre a ampliação no ensino fundamental de nove anos trouxeram considerações importantes sobre a avaliação das crianças de seis anos no ensino fundamental, levando em consideração o processo de avaliação na educação infantil. Por exemplo, o documento "Orientações Gerais para a Inclusão das Crianças de 6 anos no Ensino Fundamental" (BRASIL, 2006d) no texto “Avaliação e Aprendizagem na Escola: a Prática Pedagógica como eixo da Reflexão" afirma que:

...a avaliação (quando não se limita a produzir notas ou conceitos para fins de aprovação-reprovação ou certificação de estudos) constitui sempre processo contínuo de observação dos avanços, das descobertas, das hipóteses em construção e das dificuldades demonstradas pelos meninos e meninas na escola. Neste processo, realizamos um diagnóstico do que os estudantes já sabem, ao iniciarmos uma etapa de ensino, e dos conhecimentos que vão construindo ao longo do período. (BRASIL 2006d, p. 102).

Outro documento que trata dessa questão: “Ampliação do Ensino Fundamental para nove anos: $3^{\circ}$ relatório do programa" (BRASIL, 2006c) cita:

\footnotetext{
Quanto à avaliação da aprendizagem no $1^{\circ}$ ano do ensino fundamental de nove anos, faz se necessário assumir como princípio que a escola deve assegurar aprendizagem de qualidade a todos; assumir a avaliação como princípio processual, diagnóstico, participativo, formativo, com o objetivo de redimensionar a ação pedagógica; elaborar instrumentos e procedimentos de observação, de registro e de reflexão constante do processo de ensinoaprendizagem; romper com a prática tradicional de avaliação limitada a resultados finais traduzidos em notas; e romper, também, com o caráter meramente classificatório. (BRASIL, 2006c, p. 10).
}

Ainda, o Parecer CNE/CEB no 4/2008, que dispôs sobre a organização dos três anos iniciais do ensino fundamental de nove anos, em seu artigo $9^{\circ}$, orientava que as avalições escolares deveriam ser realizadas diferencialmente, sem serem traduzidas em "meras notas", como costumava ocorrer no ensino fundamental:

9 - A avaliação, tanto no primeiro ano do Ensino Fundamental, com as crianças de seis anos de idade, quanto no segundo e no terceiro anos, com as crianças de sete e oito anos de idade, tem de observar alguns princípios essenciais: 9.1 - A avaliação tem de assumir forma processual, participativa, formativa, cumulativa e diagnóstica e, portanto, redimensionadora da ação pedagógica; 
9.2 - A avaliação nesses três anos iniciais não pode repetir a prática tradicional limitada a avaliar apenas os resultados finais traduzidos em notas ou conceitos; 9.3 - A avaliação, nesse bloco ou ciclo, não pode ser adotada como mera verificação de conhecimentos visando ao caráter classificatório;

9.4 - É indispensável a elaboração de instrumentos e procedimentos de observação, de acompanhamento contínuo, de registro e de reflexão permanente sobre o processo de ensino e de aprendizagem;

9.5 - A avaliação, nesse período, constituir-se-á, também, em um momento necessário à construção de conhecimentos pelas crianças no processo de alfabetização. (BRASIL, 2008a)

Esses princípios foram resgatados pelo Documento de Orientações da SME de São Bernardo do Campo, sobre o ensino fundamental de nove anos, no item 4 de avaliação, que trazia ainda, alguns aspectos da avaliação que norteavam o trabalho do professor no início da ação pedagógica, para planejar novos temas e conteúdos; durante o processo de ensino aprendizagem, definindo os instrumentos de avaliação; a importância da diversidade de instrumentos avaliativos; a organização dos portfólios; além da auto-avaliação dos alunos e de mecanismos de avaliação dos pais sobre o trabalho desenvolvido pela equipe escolar (SÃO BERNARDO DO CAMPO, 2010a).

$\mathrm{Na}$ rede municipal de ensino pesquisada, conforme explicitado anteriormente, a avaliação ocorria bimestralmente, através dos Conselhos de Classe, quando os professores elaboravam um Relatório Geral da sala, discutiam as principais dificuldades das crianças e pensavam em maneiras de trabalhar com essas dificuldades. Além disso, cada professor preenchia uma Ficha de Avaliação individual, que seria mostrada aos pais na reunião bimestral e anexada ao portfólio dos alunos. O portfólio é apresentado como um instrumento importante de avaliação no documento “Orientações para a Inclusão das Crianças de 6 anos no Ensino Fundamental":

(...) a materialidade dos portfolios permite não só ao professor, mas, sobretudo, ao estudante (e sua família), comparar o que se sabia de início com o que se foi construindo ao longo de determinada etapa escolar.” (BRASIL, 2006d, p. 104)

Essa Ficha de Avaliação foi denominada "Ficha de Rendimento Escolar do Aluno"19. Nela estavam especificados os objetivos bimestrais de cada área de conhecimento: Língua Portuguesa, Matemática, Ciências, História/Geografia, Educação Físíca e Arte; e a professora deveria anotar se o aluno tinha obtido rendimento satisfatório ou insatisfatório para cada objetivo. O professor deveria escrever, também, as dificuldades detectadas no processo ensino-aprendizagem e as providências da escola e do professor para auxiliar o aluno, além de

\footnotetext{
${ }^{19}$ A Ficha de Rendimento Escolar do Aluno do $1^{\circ}$ Bimestre, da escola pesquisada, constitui o Anexo B.
} 
marcar em qual "hipótese de escrita" a criança se encontrava. Além disso, as professoras disseram que cada criança tinha o seu portfólio, onde se podia observar a evolução delas e que a orientação era de que estes portfólios acompanhassem as crianças durante toda a caminhada escolar.

Sobre a Ficha é interessante observar a importância dada à aquisição do sistema de escrita pela criança, com uma parte específica para o preenchimento da hipótese de escrita dela, sendo que os pais, na maioria dos casos, não conheciam o significado dos termos apresentados, que, pela observação das pesquisadoras, também não foram explicados a eles na Reunião de Pais. Além disso, a divisão dos objetivos em áreas do conhecimento, segue a lógica do ensino fundamental, de divisão por disciplinas. Porém, um aspecto importante foi a apresentação das dificuldades das crianças atrelada às providências da escola e do professor para superação das mesmas, levando em consideração o princípio 9.1, citado anteriormente, que afirma que a avaliação deve ser redimensionadora da ação pedagógica.

$\mathrm{Na}$ escola pesquisada, os Conselhos de Classe do $1^{\circ}$ ano EF9 aconteceram junto com os do $1^{\mathrm{o}}$ ano EF8, pois eles acreditavam que muitos problemas seriam parecidos, por ser esse o primeiro ano das duas turmas (EF8 e EF9) no ensino fundamental e estarem os dois anos no ciclo de alfabetização, com exceção do $2^{\circ}$ Bimestre, quando eles ocorreram em dias distintos. Durante as entrevistas foi questionado o porquê disso e a explicação dada pela vice diretora foi que: "Não foi nada intencional, foi por questões de logística, questões de data, por praticidade, tanto é que no terceiro bimestre foi junto e no quarto também." (Vice-Diretora, 2010).

Os Conselhos contavam com a participação da coordenadora pedagógica e, em algumas vezes, da vice-diretora ou até mesmo da diretora, que participava principalmente, no fim do ano, nos Conselhos do ano final do ciclo, pois havia a possibilidade de repetência da criança nesses anos.

Durante as reuniões dos conselhos, as professoras liam o Relatório Geral da sala, que era utilizado internamente pela equipe escolar para acompanhar o desenvolvimento das turmas, não sendo entregue aos pais, depois apontavam os alunos que apresentavam alguma dificuldade, seja de excesso de faltas ou de dificuldade de aprendizagem, traziam as atividades dos alunos e as sondagens, discutiam os encaminhamentos que seriam tomados com os alunos e por fim mostravam algumas atividades dos alunos que elas acreditavam que avançaram mais. O Relatório Geral da Classe do $1^{\mathrm{o}}$ Bimestre, da sala que foi acompanhada pela pesquisadora informava: 
A turma é composta por 23 alunos dos quais, 4 alunos completaram 6 anos em fevereiro, sendo eles C., G., I. e V., o restanta completará 7 anos no $2^{\circ}$ semestre.

É um grupo participativo durante a Roda de Leitura, apreciam a leitura feita por mim.

$\mathrm{Na}$ dinâmica das aulas necessitam vários momentos para brincar: jogos, massinha, parque, brinquedos de montar, etc. A todo momento perguntam se já podem guardar o material, dado este que demonstra essa necessidade.

Durante as atividades propostas necessitam instrução constante, como: no uso do caderno, recorte, colagem e também no cuidado com o material escolar, "perdem tudo" a todo momento.

Estas características demonstram que o trabalho vai caminhar com um olhar especial para o desenvolvimento da autonomia nas atividades propostas (atenção ao aluno R. que ainda não consegue realizar os registros da rotina no tempo esperado, pois dispersa-se com facilidade).

Dados estes que delinearão o trabalho até o fim do ano letivo, pois apesar de muitos "novos" encerramos o bimestre com 1 pré-silábico, 0 Silábico sem valor, 4 Silábicos com valor, 4 Silábicos-alfabéticos e 14 alfabéticos. (Carderno de Campo, 2010)

A partir da leitura do Relatório nota-se a preocupação da professora com relação a autonomia das crianças e a necessidade delas de brincar, aspectos importantes da educação infantil, mas ao mesmo tempo, percebe-se a preocupação com o aluno que ainda não consegue copiar a rotina da lousa e a apresentação da quantidade de crianças em cada hipótese de escrita, resultado do trabalho de alfabetização realizado pela professora.

Durante a reunião do Conselho do $1^{\circ}$ bimestre, acompanhado pelas pesquisadoras, houve uma discussão sobre se as professoras deveriam se preocupar em alfabetizar as crianças no $1^{\mathrm{o}}$ ano EF9. Algumas professoras afirmaram que tinham dificuldade em esperar para alfabetizá-las, pois sabiam que seria difícil para aquelas que não estivessem alfabetizadas no $2^{\circ}$ ano EF9, porém, no final da discussão decidiram que as crianças que estivessem prontas seriam alfabetizadas, mas que não havia necessidade de se preocupar caso algumas não se alfabetizassem. Destaca-se aqui a presença do termo "prontas para alfabetização" novamente, mostrando a concepção de educação das crianças pequenas como forma de preparo para o que será aprendido depois e o conceito superado, mas existente no imaginário pedagógico, de “prontidão para aprendizagem".

Nesse Conselho também foi discutido o que elas deveriam esperar dos alunos do $1^{\mathrm{o}}$ ano EF9 e as professoras afirmaram que deveriam analisar mais os aspectos atitudinais e que deveriam levar em consideração o avanço de cada criança em relação a ela mesma, sem comparação com as outras, decidindo que seria melhor fazer um Relatório de cada aluno para o próximo bimestre e não utilizar a Ficha de Rendimento no $1^{\mathrm{o}}$ ano EF9. Porém, a vice diretora disse que iria conversar com a diretora, pois as fichas eram exigidas pela Secretaria Municipal de Educação e teriam que pensar em como resolver as questões burocráticas, pois, 
afirmou, que quando a Prefeitura implementou a Lei não foram feitos encaminhamentos práticos para as escolas. Apesar disso, nos demais semestres, as professoras continuaram utilizando a Ficha de Rendimento ao invés de elaborar o Relatório Individual de cada criança.

No documento de orientações para implantação do ensino fundamental de nove anos, da SME de São Bernardo do Campo, apareceu a possibilidade de utilização de outros instrumento para avaliação: "Para efetivar a participação de alunos e pais ou responsáveis, a equipe escolar poderá elaborar instrumentos específicos" (SÃO BERNARDO DO CAMPO, 2010a, p. 18). Porém, o mesmo documento reafirmava a utilização da Ficha de Rendimento: "A forma de avaliação aqui proposta estabelecerá parâmetros tanto para o replanejamento das ações pedagógicas como para o preenchimento das fichas de rendimento dos alunos, implantadas desde 2000 em nossa rede de ensino." (idem, grifos nossos).

A partir disso, pode-se questinar a questão da autonomia escolar, pois se as professoras trouxessem um aspecto importante observado por elas para melhoria da qualidade da avaliação realizada, mas não pudessem colocá-lo em prática, com a justificativa da vicediretora sobre a preocupação com a burocracia da Prefeitura que exigia a utilização das Fichas pelas escolas, efetivamente a autonomia da escola estaria comprometida em aspecto essencial do processo ensino-aprendizagem.

Após as reuniões de Conselho, ocorriam bimestralmente as Reuniões de Pais, que eram realizadas no horário normal de aula, sendo que havia um escalonamento de horário das reuniões com as turmas do mesmo ano, ou seja, uma sala do mesmo ano fazia a reunião primeiro, enquanto a outra professora ficava com as crianças desta turma e depois, a segunda fazia sua reunião, enquanto a primeira professora ficava com as crianças.

A Reunião de Pais do $2^{\circ}$ bimestre, acompanhada pelas pesquisadoras, ocorreu no dia 5 de julho. Nessa reunião compareceram aproximadamente 18 (dezoito) pais de cada sala do $1^{\circ}$ ano EF9 e a reunião teve como pauta: leitura inicial, a "Campanha contra o Piolho", o Projeto "Tempo de escola", definição do dia do retorno do recesso, que seria no dia 26 de julho, reposição dos materiais e a apresentação da Ficha de Rendimento dos alunos.

A professora iniciou a reunião fazendo a leitura do livro: "O grande rabanete", que é um livro infantil, da autora Tatiana Belinky, que conta a história de um avô que plantou um rabanete, que ficou grande demais e ele não conseguia arrancar sozinho, então ele vai chamando diversos personagens para ajudar, até que, com a ajuda do rato, no final, conseguiam arrancar o rabanete. O objetivo da professora com a leitura era que os pais refletissem sobre a importância do trabalho em equipe e a capacidade das crianças, mesmo sendo pequenas, como o rato da história. 
Após a leitura, conversou sobre a prevenção dos piolhos e a importância do tratamento; perguntou quem tinha interesse nas vagas remanescentes do Projeto "Tempo de escola"; falou sobre a importância dos alunos levarem o material escolar completo para a escola e dos pais olharem o caderno que eles levavam no fim de semana para casa e trazerem de volta na segunda-feira, afirmou que as crianças estavam brigando muito e falando muitos palavrões e também, que, com as mesinhas trazidas do Infantil V, as crianças queriam "bater papo e brincar toda hora", fala já trazida pela professora, anteriormente, em conversa informal com as pesquisadoras, demonstrando, novamente, o desentendimento da professora com as necessidades das crianças de seis anos de se expressar e brincar.

Por último, ela entregou as Fichas de Rendimento e pediu que os pais assinassem a referida Ficha e a lista de presença. Durante a reunião, os pais pouco falaram, apenas se manifestaram para tirar algumas dúvidas do que a professora estava dizendo ou para perguntar sobre o comportamento do filho, individualmente, após o final da reunião. Alguns pediram para a professora explicar a Ficha de Rendimento, pois não tinham entendido muito bem o que a Ficha dizia sobre seu filho. Essa dificuldade dos pais em entender a Ficha reforça a idéia das professoras, de que seria mais proveitoso realizar um relatório escrito de cada criança substituindo a Ficha, porém como visto antes, isso não foi feito.

\section{Implicações para os demais anos do ensino fundamental}

Os documentos do MEC sobre a ampliação do ensino fundamental para nove anos levantaram questões sobre a possibilidade de reflexão e mudança de práticas em todos os anos do ensino fundamental, não apenas nas de $1^{\circ}$ ano. Além disso, tendo a rede municipal de São Bernardo do Campo optado por manter as duas organizações do ensino fundamental (de oito e de nove anos) no ano de 2010, fez-se necessário uma análise das semelhanças e diferenças no trabalho desenvolvido pelas duas turmas e das implicações desta mudança para os demais anos do ensino fundamental.

O documento de orientações da SME de São Bernardo do Campo citado anteriormente, reafirmava a possibilidade de reavaliar o trabalho desenvolvido em todas as turmas e colocava os dois $1^{\circ}$ anos, tanto do fundamental de oito como de nove anos, no mesmo patamar de preocupações pedagógicas:

A ampliação no tempo de escolaridade das crianças significa uma importante oportunidade para reavaliarmos o trabalho que temos desenvolvido até o momento e pensarmos em novas possibilidades de trabalho. Ao mesmo tempo, nos permite 
reiterar questões importantes para o trabalho pedagógico a ser desenvolvido com todas as turmas, em especial com as turmas dos $1^{\circ}$ anos do enisno fundamental I (igualmente para as turmas do ensino fundamental de 8 e de 9 anos). (SÃO BERNARDO DO CAMPO, 2010a, p. 8)

Em função disso, considerou-se importante analisar as semelhanças e diferenças entre as duas turmas de $1^{\circ}$ ano, razão pela qual optou-se por acompanhar alguns dias letivos na turma do $1^{\circ}$ ano EF8, apesar de não ser esse o foco da pesquisa. Além disso, foram feitas conversas informais com as professoras e pode-se observar as turmas em diversos momentos, pois essas turmas realizavam algumas atividades junto com os $1^{\circ}$ anos do EF9, dentre elas o recreio que realizavam juntos diariamente.

As salas de aula das duas turmas estavam organizadas de forma bastante diferenciada, pois, ao contrário dos alunos do $1^{\circ}$ ano EF9 que sentavam agrupados em duplas e posteriormente, com a mudança das mesas, em trios, os alunos das turmas de $1^{\circ}$ ano EF8 sentavam individualmente e enfileirados um atrás do outro e as paredes das salas de aula também não contavam com tantos cartazes como as do $1^{\circ}$ ano EF9. Nessa sala também não se observou nenhum brinquedo que as crianças pudessem utilizar, como os blocos para montar ou as massinhas encontrados nas salas de $1^{\circ}$ ano EF9, que as crianças usavam quando terminavam a lição ou em alguns outros momentos da rotina.

Com relação à rotina das turmas, ela era bastante diferenciada, sendo algumas das principais diferenças observadas que: 1) no $1^{\circ}$ ano EF8, as crianças não tinham o momento de parque no início da aula, em nenhum dia; 2) elas já tinham livros didáticos de todas as disciplinas, sendo que os de Português e Matemática eram consumíveis e 3) elas faziam provas de Português e Matemática, pois as professoras consideravam importante que elas se acostumassem a fazer provas, pois afirmaram, em conversa informal, que quando chegassem ao $2^{\circ}$ ano e tivessem que fazer a avaliação do Sistema de Avaliação do Rendimento Escolar do Estado de São Paulo (SARESP) ${ }^{20}$, além de outras provas, muitas vezes não estavam acostumadas e iriam mal por esse motivo.

No $1^{\circ}$ ano do EF8, a cobrança com relação à alfabetização também era maior, sendo considerado pelas duas professoras do período da manhã e pela direção escolar que, nesse ano era importante que todas as crianças fossem alfabetizadas, tendo isso sido discutido nos

\footnotetext{
20 Segundo o site da Secretaria Estadual de Educação de São Paulo o SARESP é uma avaliação externa da Educação Básica, realizada desde 1996 pela Secretaria da Educação do Estado de São Paulo. O Saresp tem como finalidade produzir informações consistentes, periódicas e comparáveis sobre a situação da escolaridade básica na rede pública de ensino paulista, visando orientar os gestores do ensino no monitoramento das políticas voltadas para a melhoria da qualidade educacional.
} 
Conselhos de Classe/Ano, já que foram realizados junto com os do $1^{\circ}$ ano EF9, com exceção do $2^{\circ}$ bimestre, como explicado anteriormente.

Apesar das turmas terem essas diferenças com relação a organização das salas de aula e da rotina escolar, pode-se afirmar que tinha havido algumas mudanças para esse $1^{\circ}$ ano, com a chegada das crianças menores ao ensino fundamental na sala do $1^{\circ}$ ano EF9. Uma dessas mudanças foi a incorporação, na rotina, de momentos para cantar e dançar músicas infantis, junto com outras turmas do $1^{\circ}$ ano EF8 e do $1^{\circ}$ ano EF9, que aconteceram no $1^{\circ}$ semestre e foram citados anteriormente. Outra mudança importante foi a criação da brinquedoteca no $2^{\circ}$ semestre de 2010, que também foi destinada às crianças dos $1^{\circ}$ anos do EF8 e que, antes, não contavam com esse espaço.

Além disso, pode-se observar em vários momentos, na fala da direção da escola, uma preocupação maior com relação ao lúdico em todas os anos do ensino fundamental, porém não é possíver afirmar que essa preocupação realmente tenha feito parte do planejamento e da prática de todas as professoras ou se ficou limitada apenas, ao $1^{\circ}$ ano do EF9, como parece ter ocorrido.

Em conversa informal com uma professora do $1^{\circ}$ ano EF9, ela informou que eles precisaram cobrir com papel a porta da brinquedoteca, pois ela era de vidro e os alunos das demais séries passavam pela sala e cuspiam na porta. É interessante notar que talvez os alunos estivessem "chateados" por não poderem utilizar a sala que foi destinada apenas aos alunos menores. A diretora afirmou que, para os alunos dos outros anos, foram comprados diversos jogos que ficavam guardados na sala dos inspetores podendo ser solicitados pelas professoras, em qualquer momento. Porém, não se pode afirmar se isso realmente ocorria, se eram todas as professoras que costumavam utilizar os jogos ou em quais momentos utilizavam, já que os alunos pareciam estar descontentes por não usar a brinquedoteca, mesmo com os jogos, teoricamente, à disposição.

Se por um lado, com a entrada das crianças de seis anos no ensino fundamental, houve a preocupação com a compra de brinquedos e jogos para as crianças de todas as turmas, por outro, apenas algumas crianças foram privilegiadas com o uso da brinquedoteca, não atendendo, assim, as expectativas dos documentos oficiais e da própria Secretária de Educação, que, durante a entrevista, afirmou que:

Isso fez com que a nossa rede fizesse uma reflexão também sobre as crianças de 7 anos. De 7, de 8 e de 9, com a entrada destas crianças de 6 nas escolas de ensino fundamental nós conseguimos sensibilizar mais a importância do direito da criança brincar" (Secretária de Educação de São Bernardo do Campo, 2011). 
Com relação a esse tema, uma preocupação apontada por Aline Marin e Flávia Pansini é que:

\begin{abstract}
Se ingressar aos seis anos significar a expansão da educação infantil a partir dos maiores e dos que necessitam com urgência de uma experiencia de letramento através de um projeto pedagógico voltado para ludicidade, para o desenvolvimento das diversas linguagens simbólicas para as interações sociais, para o jogo e a brincadeira, isto é, para viver a infância, então ótimo. No entanto, se significar "o massacre dos inocentes", como é para aquele terço das crianças que está com sete anos na primeira série do ensino fundamental, é preciso repensar seriamente essa proposta. (BARBOSA apud MARIN e PANSINI, 2011, p. 100)
\end{abstract}

\title{
Opinião dos pais e das crianças sobre qualidade na educação
}

Os pais entrevistados foram perguntados sobre o que consideravam ser uma boa escola para as crianças de seis anos. Muitos pais responderam que consideravam a escola que os seus filhos estavam matriculados, uma boa escola, por gostar do que eles estavam aprendendo, pelo filho já estar quase lendo e escrevendo, por considerarem a professora da turma, uma boa professora, organizada, que dava atenção e ajudava as crianças que estavam com dificuldades. Outra mãe afirmou que a escola era ótima, que sempre conversava com a diretora, que fazia parte da APM e do Conselho de Escola e que as professoras eram maravilhosas e uma terceira mãe afirmou que a escola era boa e que considerava que faltava apenas um parquinho.

Outros pais disseram que uma boa escola precisava de mais de um professor por sala, precisava ter segurança, boa merenda, boa comida, boa professora e diretora e que as crianças deveriam brincar, fazer desenho, ter atividades criativas. Outra mãe afirmou que a escola deveria ter mais atividades extras, fora da sala de aula, como aula de teatro, educação física e outros cursos, e o último pai disse que a escola precisaria ter bons funcionários, professores com alta competência, que todos deveriam ser mais responsáveis na escola e acreditava que essa escola deixava a desejar nessa parte.

É importante considerar que não há consenso sobre o que seria considerado uma escola de boa qualidade: "Sacristán (2001) destaca que as representações sociais em torno do valor da escolarização universal são múltiplas e diversas, o que vai conferir significados distintos para as representações sociais em torno da qualidade do ensino.” (ARAUJO; OLIVEIRA, 2005, p. 17).

Mas, a partir dessas considerações, pode-se perceber que, de maneira geral, os pais associam uma escola de qualidade a uma boa professora, que seja competente e ajude as 
crianças; à aprendizagem das crianças, principalmente na leitura e escrita e na diversidade de aulas e atividades que as crianças tenham na escola. Cabe destacar que a maioria dos pais entrevistados considerava a escola pesquisada uma "boa escola". Além disso, pareceu que os pais gostavam do que entendiam ser uma antecipação do ensino, por acreditarem que as crianças estavam ganhando tempo, ao serem alfabetizadas mais cedo.

Com as crianças foi utilizada a metodologia de grupo focal, sendo realizados quatro grupos, com 4 a 5 crianças em cada grupo, totalizando 20 crianças, conforme explicitado anteriormente. Após contar a história do amigo Sebastião, a pesquisadora perguntou às crianças o que elas faziam nessa escola, e elas responderam que "chegavam, rezavam, faziam lição, iam para o almoço, brincavam no parque, voltavam para sala fazer mais lição e quando terminavam podiam brincar." Depois, a pesquisadora perguntou o que elas mais gostavam de fazer na escola, sendo as respostas bem variadas: "continha, desenhar, fazer lição, brincar na quadra, matemática, jogar futebol, aprender a ler, brinquedoteca, informática, brincar de pegapega e brincar no parque." E, em seguida, perguntou o que elas não gostavam de fazer na escola, tendo, a maioria das respostas, relação com a lição ou com brigas entre os colegas, com exceção de duas crianças que disseram não gostar de pular corda (Crianças 12 e 15) e uma que disse "Eu gosto da quadra, mas a professora não vai na quadra" (Criança 4).

Após saber o que as crianças gostavam e não gostavam em sua escola, perguntou o que elas mudariam na escola se pudessem. Duas crianças falaram que colocariam regras para as crianças não ficarem bagunçando e se batendo. Mas as respostas se concentraram, basicamente, em mais tempo para brincar e mais brinquedos.

Criança 3 - Se eu fosse presidente desta escola eu ia mudar as lousas, eu ia colocar maior (...) na biblioteca eu ia colocar uma televisão, eu ia colocar uma telona.

Criança 1 - Eu também sei. Se eu fosse presidente desta escola eu ia mudar para a gente ir na brinquedoteca nos finais de semana e nas sextas-feiras.

Criança 3 - eu também ia querer que a gente ia (sic) para quadra todo dia.

(...)

Lara - E se vocês pudessem mudar alguma coisa aqui na escola o que vocês mudariam?

Criança 7 - A lição.

Lara - Você mudaria como?

Criança 7 - (risos) Eu colocaria toda hora brincar.

Criança 6 - Colocaria brinquedo na sala toda.

Criança 10 - Só desenho.

Criança 6 - Não. Desenho e ter um monte de presente.

(...)

Criança 14 - Eu gostaria de mudar os brinquedos porque tem poucos brinquedos na escola.

(...)

Criança 11 - Eu queria que tivesse piscina de bolinha, computador, laptop, um monte de coisa (...) Ter brinquedos novos e ter uma professora muito, muito, muito e muito legal que deixasse a gente só brincar mesmo, depois que acabasse a aula de 
brincar a gente fizesse só um pouquinho de lição e a gente ia embora. (Crianças entrevistadas, 2010)

A partir dessas respostas, pode-se perceber a necessidade que as crianças dessa faixa etária tem de brincar, pois a maior parte das respostas se concentrou em brinquedos e atividades ligadas ao brincar.

Quando a pesquisadora perguntou se as crianças de seis anos deveriam ir para escola, todas as crianças responderam afirmativamente, justificando:

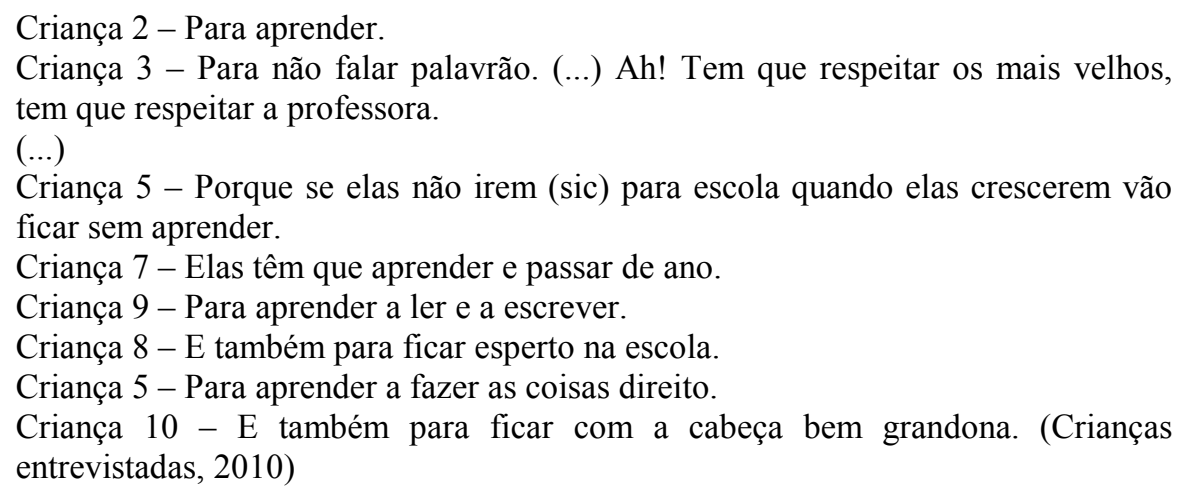

Isso pode demonstrar a clareza que as crianças de seis anos tem sobre a importância da escola, pois nenhum delas respondeu negativamente a questão.

Com relação à escola de educação infantil, todas as crianças disseram ter estudado em uma escola antes de virem para esta escola, porém, quando questionadas se preferiam estudar mais um ano na escola anterior ou nessa em que estavam matriculadas agora, as respostas foram bem divididas, algumas crianças afirmaram preferir a escola em que estavam estudando, de ensino fundamental, porque:

\footnotetext{
Lara - E você, qual escola você prefere?

Criança 2 - Eu prefiro aqui.

Lara - Por quê?

Criança 2 - Porque eu gosto de ficar com os colegas grandes.

Criança 8- Eu gosto mais desta escola porque aqui nós aprendemos mais coisa.

Criança 9 - Porque aqui eu posso aprender melhor a ler, a escrever e a fazer mais lição.

Criança 6 - Eu também acho a mesma coisa.

(...)

Criança 14 - Aqui. Porque aqui tem um monte de coisa para ver e para fazer. Lá só tinha desenho.

Criança 17 - (...) aqui da muita lição, mas agora eu prefiro ficar aqui porque eu estou aprendendo a ler. Antes eu gostava de ficar na creche. (Crianças entrevistadas, 2010)
}

Outras crianças afirmaram preferir a escola de educação infantil: 
Criança 1 - Ah, as professoras de lá são mais legais porque cantam as músicas

(...)

Criança $11-(\ldots)$ porque lá tinha polícia, tinha corda, tinha pula-pula, tinha piscina de bolinhas, de água, tinha também um montão de bexigas também, eles davam chocolate, eles davam cachorro-quente também. Tinha uma tia que fazia a gente fazer um montão de lição e quando a gente ficava na quadra a professora deixava a gente desenhar e fazer um montão de coisas lá.

(...)

Criança 20 - Porque eu gostava de fazer bagunça.

Criança 18 - A professora levava a gente para o parque. (Crianças entrevistadas, 2010)

E, algumas ficaram divididas:

Criança 3 - eu queria ficar aqui, porque aqui tem brinquedoteca e lá não tinha. Não, mais eu queria ficar um pouco naquela e um pouco nesta, porque lá também tinha uma ponte de madeira.

(...)

Criança 17 - Eu acho lá. Aqui dá muita lição, mas agora eu prefiro ficar aqui porque eu estou aprendendo a ler. Antes eu gostava de ficar na creche. (Crianças entrevistadas, 2010)

Uma criança afirmou, ainda, ficar chateada quando assistia o DVD da outra escola: "Sabia que eu tenho o DVD da outra escola e você sabia que sempre quando eu assisto, eu choro? Porque eu sinto falta daquela escola."(Criança 3, 2010). Outra aluna disse que: "Para a B. tem que ser pequena, para a gente, que é maior, tem que ser grande.” (Criança 14, 2010) E duas crianças afirmaram que as crianças pequenas não devem ficar na escola das crianças grandes "porque eles batem na gente" (Criança 16, 2010) e criança grande bate, fica mostrando o dedo, fica falando das professoras por detrás, fica xingando o amigo, fica xingando a gente, então...”. (Criança 11, 2010) E, por último, uma aluna comentou, que sua prima deveria ter ido para o "prezinho", mas que veio direto para a $1^{a}$ série:

Criança 18: A minha prima tinha que ir para o prezinho e ao invés dela passar por uma sala igual a esta, ela veio direto para a primeira série.

Pesquisadora: E você acha isso legal?

Criança 18: Não, ela tinha que passar pelo prezinho primeiro.

Pesquisadora: Porque você acha que ela deveria passar pelo prezinho primeiro?

Criança 18: Porque ela já ia sair do prezinho, já muito esperta. (Criança entrevistada, 2010)

Após a conversa, pediu-se às crianças que fizesem um desenho da escola para que as Pesquisadoras levassem ao seu "amigo Sebastião". Os desenhos foram bem variados, algumas crianças desenharam a quadra da escola, outras o parque, a escola inteira e algumas, a sua sala 
de aula. Foram selecionados alguns desenhos realizados pelas crianças, que constam no Apêndice D, deste trabalho.

A partir das respostas das crianças, pode-se perceber o quanto elas tem a contribuir com as pesquisas educacionais e para a melhoria da qualidade da educação, pois se elas são as principais envolvidas no processo de ensino-aprendizagem, suas opiniões devem ser ouvidas, respeitadas e levadas em consideração na criação e efetivação das políticas públicas educacionais. 


\section{Considerações Finais}

Eu gosto de fazer lição, só não gosto de escrever muita coisa que a "prô" passa.

(Criança 5)

A implementação da ampliação da duração do ensino fundamental, em especial com a antecipação da idade de ingresso das crianças, confirmada pela Lei federal $n^{\circ} 11.274 / 2006$, estava prevista como meta do PNE. Contudo, é importante refletir sobre a forma de efetivação dessa medida, que altera sobremaneira a estrutura do sistema de ensino brasileiro. Levando-se em consideração os limites da Pesquisa, que objetivou acompanhar a implementação do ensino fundamental de nove anos em uma escola da rede municipal de ensino, do Município de São Bernardo do Campo, é importante levantar algumas considerações com relação aos três eixos analisados: direito à educação, qualidade do ensino e gestão democrática.

Pode-se verificar, inicialmente, que, embora a razão prioritária para essa reorganização, na opinião da maior parte dos participantes da Pesquisa e no discurso dos documentos oficiais do Ministério da Educação, tenha sido a ampliação do direito à educação, foi possível constatar que, efetivamente, isso não ocorreu, pois não houve aumento do número de matrículas na educação infantil e no ensino fundamental, no município pesquisado e, no caso, as crianças do $1^{\circ}$ ano EF9 da escola pesquisada já frequentavam uma escola de educação infantil.

Além disso, apesar do Município de São Bernardo do Campo ser um dos mais ricos do Brasil, conforme apontado anteriormente, tampouco houve o financiamento adequado, com investimento de recursos financeiros suficientes para proporcionar às escolas condições mais apropriadas para recepção das crianças mais novas no ensino fundamental, com reformas e adaptação de mobiliários, já que, por exemplo, a escola pesquisada não recebeu carteiras novas para as crianças do $1^{\circ}$ ano EF9, as adaptações do banheiro ficaram sob responsabilidade da direção escolar e não houve o conserto do parque durante todo o ano de 2010.

Outras medidas poderiam ter sido adotadas pelo Estado brasileiro para assegurar o direito à educação, como por exemplo, a transformação do último ano da educação infantil em escolarização obrigatória, o que só ocorreu posteriormente, com a Emenda Constitucional $n^{\circ}$ 59/2009, que considerou obrigatória, a partir de 2016, a educação dos 4 aos 17 anos de idade. Essa Emenda construiu um cenário ainda mais contraditório, não só para a educação infantil, mas também para a nova organização do ensino fundamental, pois se já havia intenção por parte do Governo Federal de ampliar a obrigatoriedade do ensino a partir dos 4 anos, por que 
obrigar as crianças de 6 anos a se matricularem no ensino fundamental ao invés de mantê-las na educação infantil?

Pode-se questionar, ainda, até que ponto a inserção de um ano da escolaridade obrigatória, já oferecida em outra etapa de ensino: a educação infantil, se traduz de fato em ampliação do direito à educação, sem a garantia de um atendimento de qualidade para as crianças de seis anos. A esse respeito, Araújo e Oliveira (2005) afirmam que:

(...) o grande desafio do atual momento histórico, no que diz respeito ao direito à educação, é fazer com que ele seja, além de garantido e efetivado por meio de medidas de universalização do acesso e da permanência, uma experiência enriquecedora do ponto de vista humano, político e social, e que consubstancie, de fato, um projeto de emancipação e inserção social. Portanto, que o direito à educação tenha como pressuposto um ensino básico de qualidade para todos e que não (re) produza mecanismos de diferenciação e de exclusão social. (ARAUJO; OLIVEIRA, 2005, p. 16).

O que se pode constatar na pesquisa de campo, sobre a qualidade do ensino oferecida às crianças de seis anos no ensino fundamental, foi que a política da Secretaria Municipal de Educação apareceu pouco na escola pesquisada, tendo-se a sensação que as escolas ficaram meio sem rumo, conduzindo o trabalho com os $1^{\circ}$ anos EF9 de modo mais ou menos adequado, dependendo da "sorte" de haver profissionais mais ou menos qualificados para trabalhar com as crianças de seis anos.

Por exemplo, com relação à formação dos professores, aspecto apresentado como fundamental em quase todos os documentos do MEC sobre essa ampliação do ensino fundamental e na fala da própria Secretária de Educação, durante a entrevista, não foi efetivado na escola pesquisada, pois as professoras não tiveram oportunidade de participar de nenhum curso sobre o assunto. Tampouco, na escola, essa formação apareceu registrada no Livro de Registro das Reuniões de HTPC dos professores, priorizando-se aspectos mais informativos ou de encaminhamentos, como a elaboração da Ficha de Rendimentos do $1^{\mathrm{o}}$ ano EF9.

Além disso, apesar das codições favoráveis observadas na escola pesquisada, que contava com um número reduzido de crianças por sala de aula, presença da educação infantil na própria escola, professoras que gostavam de trabalhar juntas e que estavam preocupadas com a formulação de uma proposta curricular diferente da antiga $1^{\text {a }}$ série, com aspectos mais lúdicos para o $1^{\circ}$ ano EF9, no dia a dia percebeu-se, em diversos momentos, a preocupação das professoras com a alfabetização, aspecto também observado na fala da vice-diretora e da diretora em conversas informais, tanto durante a observação da rotina escolar, quanto nas 
entrevistas. Outro problema foi o fato da proposta curricular não ter sido elaborada em conjunto com as professoras da educação infantil, que trariam considerações importantes sobre as características das crianças de seis anos.

Ainda, a Secretaria de Educação exigia a realização das "sondagens de escrita" pelas professoras do $1^{\circ}$ ano EF9 e a utilização das Fichas de Rendimentos, como nos demais anos do ensino fundamental, prejudicando a proposta das professoras de utilizar Relatórios descritivos para avaliação dos $1^{\circ}$ anos EF9, que poderiam ter sido mais interessante para avaliação das crianças de seis anos, como normalmente ocorre na educação infantil, além de comprometer a autonomia escolar.

Com relação às possíveis implicações positivas para os demais anos do ensino fundamental, defendida nos documentos oficiais, tanto do MEC, como da Secretaria de Educação de São Bernardo do Campo e na própria fala da Secretária de Educação, quando da entrevista, de fato observaram-se algumas mudanças positivas na escola pesquisada, como a realização dos momentos de cantoria, tanto no $1^{\mathrm{o}}$ ano EF9, como no $1^{\mathrm{o}}$ ano EF8 e, principalmente, com a organização da brinquedoteca no espaço escolar, que passou a ser utilizada pelas crianças da educação infantil e de sete anos do $1^{\circ}$ ano EF8, além das do $1^{\circ}$ ano EF9. Porém, como explicitado anteriormente, essas mudanças não atingiram os demais anos do ensino fundamental, sendo voltadas mais para os $1^{\circ}$ anos EF8, que mesmo assim, contavam com uma estrutura de ensino bem diferente do $1^{\circ}$ ano EF9, apesar da proximidade de idade das crianças.

É importante destacar que, se os adultos ouvissem mais as crianças, em suas manifestações corporais, de "indisciplina" e nas próprias falas delas, poderiam perceber o quanto elas sabem sobre suas necessidades de brincar, de aprender e, principalmente, de aprender brincando, pois, a partir da observação da rotina das crianças e da realização da entrevista em grupo e da confecção de seus desenhos, pode-se identificar o quanto elas conhecem o ambiente escolar, acreditam na importância de estar nele e trazem a vontade de ir para escola conviver com as outras crianças, para ter seu direito ao desenvolvimento integral garantido.

Sobre a discussão de gestão democrática, a gestão da escola estabelecida na Constituição Federal de 1988 (art. 206, inciso VI) e na LDB/96 (art. 14) deveria contar com a participação da comunidade escolar (pais, alunos, professores e demais funcionários) portanto, deveria ter sido estabelecida uma relação democrática na gestão da escola. Embora sejam direitos garantidos no corpo das leis, ainda hoje são poucas as experiências promissoras que avançaram na efetivação deste direito. O mais comum, infelizmente, são decisões de 
políticas públicas tomadas pela autoridade superior sem consulta ou participação da população usuária do serviço. Como exemplo, pode-se citar a forma como se deu o processo de elaboração e implementação das Leis federais $n^{\text {os }} 11.114 / 2005$ e 11.274/2006 e suas disposições correlatas no Município pesquisado, que alteraram a organização do ensino fundamental e trouxeram, em consequência, implicações para toda a educação básica.

Os resultados obtidos na pesquisa de campo demonstraram que não havia consenso sobre a ampliação do ensino fundamental entre os professores, gestores e pais/responsáveis da escola pesquisada. Os dados mostraram que, a maioria dos envolvidos, na escola, nem chegou a discutir o assunto, e alguns sequer tinham tido conhecimento sobre tais mudanças.

Além disso, há diversas opiniões da comunidade escolar sobre o tema, no entanto, estas opiniões não foram consideradas no momento da elaboração e implementação dessa política. Por exemplo, quando se verificou, através das entrevistas, que não houve consulta aos pais acerca da escolha da escola em que queriam que seus filhos estudassem, se queriam que estes permanecessem na educação infantil ou fossem para o ensino fundamental. Foi observado que muitos pais perceberam que algumas crianças ainda não estavam preparadas para se adaptar à rotina do ensino fundamental e por isso observaram que seus filhos tiveram bastante dificuldades no âmbito do ensino-aprendizagem o que, algumas vezes, esteve associado à indisciplina em sala de aula.

Por outro lado, professores e gestores também demonstraram insegurança em relação à maneira com que receberiam estas crianças pois, apesar da diretora da escola ter participado da Comissão que elaborou o documento "Orientações para implantação do ensino fundamental de 9 anos", o documento não foi discutido na escola e, no decorrer do ano de 2010, as professoras e gestores não foram consultados para a elaboração das alterações necessárias para o atendimento dessa nova faixa etária no ensino fundamental.

Sendo assim, a Pesquisa demonstrou que, apesar de diretriz admitida como necessária, a gestão democrática ainda tem um longo caminho a percorrer para se tornar efetiva no sistema educacional brasileiro. A participação nas discussões das demandas escolares não chega à sociedade em geral, que é a maior interessada nelas. Pelo contrario, ela é apenas informada, e às vezes muito mal, sobre as decisões que foram tomadas em instâncias superiores e que acarretam mudanças diretas nas suas vidas.

Com relação a esta questão, Paro (2001) confirma: 
participar das decisões que dizem respeito à organização e funcionamento da escola." (PARO, 2001, p. 160).

E Arelaro, Jacomini e Kelin (2011) também afirmaram que:

\begin{abstract}
Embora garantida na legislação, a prática da gestão escolar nem semrpe considera os elementos básicos da gestão democrática: a participação e a tomada de decisão de forma coletiva, garantindo a manifestação das diferentes opiniões. Em relação à gestão da escola, muitas vezes, a participação, especialmente a de pais e alunos, nas instâncias de discussão e decisão é meramente formal. Não raro os pais e os alunos e, em alguns casos, também os professores são informados, e não consultados, sobre as questões educacionais que lhes dizem respeito. (ARELARO; JACOMINI; KLEIN, 2011, p. 38)
\end{abstract}

É fato que os educadores vêm assistindo, há longo tempo, a diversas alterações na estrutura do ensino brasileiro sem que tenham sido consultados sobre tais mudanças. A nova estrutura do ensino fundamental se configura como mais uma dessas alterações que atinge diretamente os professores, responsáveis e alunos e traz inúmeros problemas que poderiam ter sido evitados caso houvesse uma consulta, um debate efetivo, antes da sua implantação:

(...) é preciso conhecer a opinião dos atores (professores, alunos, pais, direção, demais funcionários), seus interesses e expectativa, visão da educação e dos problemas a ela correlato, bem como os determinantes de suas posturas e sua disposição para aderir a novas propostas. (PARO, 2006, p. 28)

Evidencia-se, portanto, a partir dos dados coletados, uma clara deficiência quanto ao debate para a implementação de tal medida, o que impossibilitou - ou possibilitou muito pouco - a participação dos atores educacionais envolvidos no processo. A gestão democrática estabelecida em Lei não foi implementada para a efetivação dessa política pública voltada à educação.

Por fim, é importante destacar que novas pesquisas se fazem necessárias para o acompanhamento do ensino fundamental de nove anos, do $1^{\circ}$ ao $9^{\circ}$ ano, pois, a partir de conversa informal com a professora da sala de informática, em março de 2011, verificou-se que haviam acontecido algumas mudanças nos $1^{\circ}$ anos EF9, em 2011. Dentre outras, pode-se destacar a abertura de salas do Infantil IV na escola pesquisada, o que gerou que apenas uma sala de $1^{\circ}$ ano tenha contado com o mobiliário adequado, pois as outras mesas e cadeiras disponíveis passaram a ser utilizadas pelas crianças de 4 anos da educação infantil. Além disso, os alunos do $1^{\mathrm{o}}$ ano só poderiam ir à brinquedoteca apenas uma vez por semana, pois a prioridade de uso passou para a educação infantil, o que gerou uma situação contraditória, 
pois não se valorizou a entrada das crianças de seis anos no ensino fundamental, para quem a brinquedoteca havia sido montada no ano anterior.

Com relação às crianças que passaram para o $2^{\circ}$ ano EF9, a professora de informática declarou que, em 2011, as turmas de $2^{\circ}$ ano EF8 e $2^{\circ}$ ano EF9 estavam trabalhando com os mesmo conteúdos, mas que ela acreditava que não deveria ser assim, já que eram crianças com idades e turmas distintas. Afirmou, ainda, que as professoras ainda não haviam conseguido determinar o currículo desse $2^{\circ}$ ano EF9, daí essa confusão.

Percebe-se que, se, em 2010, a própria Secretária de Educação e a diretora da escola pesquisada afirmaram que a política da rede municipal seria de acompanhar as turmas de $1^{\circ}$ ano EF9 “de perto", e, mesmo assim existiram muitos problemas, parece que, em 2011, as crianças de seis anos, na escola pesquisada, foram mais prejudicadas e o currículo do ensino fundamental de nove anos, ainda não estava elaborado na rede municipal de São Bernardo do Campo e na escola.

Esta é a razão porque é primordial continuar acompanhando essa política educacional, para garantia do direito e da qualidade do ensino das crianças, pois:

O que constatamos é a persistência, por parte de nossos governantes, na formulação de decretos, resoluções, documentos de orientações e afins sem, contudo, oferecer ou garantir as condições materiais necessárias para a viabilização do que se propõe nessas formulações. Parece ser este o caso, mais uma vez, da "política" de ampliação do EF, pois se limitando ao aumento de um ano de escolaridade para todas as crianças de seis anos sem alterar a lógica de funcionamento da escola que temos, promove apenas “mais do mesmo". (CORREA, 2010, p.2) 


\section{Referências Bibliográficas}

ADRIÃO, T. e OLIVEIRA, R. P. (orgs.) Gestão, financiamento e direito à educação: análise da LDB e da Constituição Federal, 2ª ed. São Paulo: Xamã, 2001.

ARAÚJO, G. C.; OLIVEIRA, R. P. Qualidade do ensino: uma nova dimensao da luta pelo direito à educaçao. Revista Brasileira de Educação, Rio de Janeiro, v. 28, n.28, p. 5-23, 2005 .

ARELARO, L. R. (coord). et al O Ensino Fundamental de Nove Anos no estado de São Paulo: um estudo exploratório sobre sua implementação. São Paulo: FEUSP, 2012, 107p. Relatório de pesquisa - Faculdade de Educação, Universidade de São Paulo. São Paulo, 2012.

ARELARO, L. R. O Ensino Fundamental no Brasil: avanços, perplexidades e tendências. Educação e Sociedade. Campinas, v. 26, n 92, p. 1039-1066, out. 2005.

ARELARO, L. R.; JACOMINI, M. A.; KLEIN, S. B. O ensino fundamental de nove anos e o direito à educação. Educação e Pesquisa, São Paulo, v. 37, n 1, p. 35 - 49, Jan/Abr. 2011.

AZEVEDO, F. de et al. Manifesto dos Pioneiros da Educação Nova. Revista Brasileira de Estudos Pedagógicos, Rio de Janeiro, v. 65, n.150, p. 407-25, mai/ago, 1984.

BRASIL. Constituição Federal (1934). Constituição da República dos Estados Unidos do Brasil, promulgada em 16 de julho de 1934. Disponível em: < $\underline{\text { http://planalto.gov.br/> Acesso }}$ em $25 / 09 / 2012$

. Constituição Federal (1937). Constituição da República dos Estados Unidos do Brasil, promulgada em 10 de novembro de 1937. Disponível em: < $\underline{\text { http://planalto.gov.br/ }>}$ Acesso em 25/09/2012

Constituição Federal (1946). Constituição da República dos Estados Unidos do Brasil, promulgada em 18 de setembro de 1946. Disponível em: < http://planalto.gov.br/> Acesso em 25/09/2012

Constituição Federal (1967). Constituição da República Federativa do Brasil,

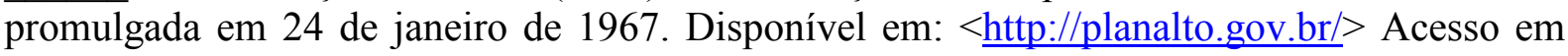
$25 / 09 / 2012$

. Constituição Federal (1988). Constituição da República Federativa do Brasil, 


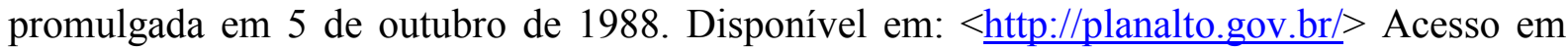
$25 / 09 / 2012$

. Constituição Federal (1988). Emenda Constitucional nº 1, de 17 de outubro de 1969. Altera a Constituição Federal de 1967 em sua íntegra. Disponível em: $<\underline{\text { http://planalto.gov.br/> Acesso em: 25/09/2012 }}$

Constituição Federal (1988). Emenda Constitucional $n^{0}$ 14, de 12 de setembro de 1996. Modifica os artigos 34, 208, 211 e 212 da Constituição Federal e dá nova redação ao artigo 60 das Disposições constitucionais Transitórias. Diário Oficial da União, Brasília, DF, 13/09/1996. Seção 1, p. 18109-18110 (1996a)

. Constituição Federal (1988). Emenda Constitucional no 59, de 11 de novembro de 2009. Acrescenta $\S 3^{\circ}$ ao art. 76 do Ato das Disposições Constitucionais Transitórias para reduzir, anualmente, a partir do exercício de 2009, o percentual da Desvinculação das Receitas da União incidente sobre os recursos destinados à manutenção e desenvolvimento do ensino de que trata o art. 212 da Constituição Federal, dá nova redação aos incisos I e VII do art. 208, de forma a prever a obrigatoriedade do ensino de quatro a dezessete anos e ampliar a abrangência dos programas suplementares para todas as etapas da educação básica, e dá nova redação ao $\S 4^{\circ}$ do art. 211 e ao $\S 3^{\circ}$ do art. 212 e ao caput do art. 214 , com a inserção neste dispositivo de inciso VI. Diário Oficial da União, Brasília, DF, 12/11/2009, p. 8. (2009b).

Constituição Federal (1988). Emenda Constitucional no 53, de 19 de dezembro de 2006. Dá nova redação aos arts. $7^{\circ}, 23,30,206,208,211$ e 212 da Constituição Federal e ao art. 60 do Ato das Disposições Constitucionais Transitórias Diário Oficial da União, Brasília, DF, 20/12/2006, p. 5. (2006b).

Lei Federal $n^{\circ}$ 8.069, de 13 de julho de 1990. Dispõe sobre o Estatuto da Criança e do Adolescente e dá outras providências. Disponível em: $<$ http://planalto.gov.br/ $>$ Acesso em 25/09/2012.

Lei Federal no 9.394, de 20 de dezembro de 1996. Estabelece as Diretrizes e Bases da Educação Nacional (LBD). Diário Oficial da União, Brasília, DF, 23/12/1996, Seção 1, p. 27833-27841 (1996b)

Lei Federal no. 9.424, de 24 de dezembro de 1996. Dispõe sobre o Fundo de Manutenção e Desenvolvimento do Ensino Fundamental e de Valorização do Magistério, na forma prevista no art. $60, \S 7^{\circ}$, do Ato das Disposições Constitucionais transitórias, e dá outras providências. Diário Oficial da União, Brasília, DF, 26/12/1996. Seção 1, p. 2844228443 (1996c) 
Lei Federal $\mathrm{n}^{\mathrm{o}}$ 10.172, de 9 de janeiro de 2001. Aprova o Plano Nacional de Educação e dá outras providências. Diário Oficial da União, Brasília, DF, 10/01/2001. Seção 1, p. $1-20$.

. Lei Federal $n^{\circ} 11.114$, de 9 de maio de 2005. Altera os artigos $6^{\circ}, 30,32$ e 87 da Lei $\mathrm{n}^{\circ}$ 9.394, de 20 de dezembro de 1996, com o objetivo de tornar obrigatório o início do ensino fundamental aos seis anos de idade. Diário Oficial da União, Brasília, DF, 17/05/2005. Seção 1, p.1. (2005a)

. Lei Federal $n^{\circ} 11.274,06$ de fevereiro de 2006. Altera a redação dos arts. 29, 30, 32 e 87 da Lei no 9.394, de 20 de dezembro de 1996, que estabelece as diretrizes e bases da educação nacional, dispondo sobre a duração de 9 (nove) anos para o ensino fundamental, com matrícula obrigatória a partir dos 6 (seis) anos de idade. Diário Oficial da União, Brasília, DF, 07/02/2006, Seção 1, p. 1-2. (2006a).

. Lei Federal $n^{0} 11.700$, de 13 de junho de 2008. Acrescenta inciso X ao caput do art. $\overline{4^{0}}$ da Lei $\mathrm{n}^{\mathrm{o}}$ 9.394, de 20 de dezembro de 1996, para assegurar vaga na escola pública de educação infantil ou de ensino fundamental mais próxima de sua residência a toda criança a partir dos 4 (quatro) anos de idade. Disponível em: <http://planalto.gov.br/> Acesso em 25/09/2012. (2008b)

Lei Federal $\mathrm{n}^{\mathrm{o}}$ 12.061, de 27 de outubro de 2009. Altera o inciso II do art. $4^{\mathrm{o}} \mathrm{e} \mathrm{o}$ inciso VI do art. 10 da Lei $\mathrm{n}^{\mathrm{o}}$ 9.394, de 20 de dezembro de 1996, para assegurar o acesso de todos os interessados ao ensino médio público. Disponível em: < $\underline{\text { http://planalto.gov.br/ }>}$ Acesso em 25/09/2012. (2009b)

Ministério da Educação e do Desporto. Secretaria de Ensino Fundamental. Referencial Curricular Nacional para a Educacão Infantil. Brasília: MEC/SEF, 1998, 3v.

. Ministério da Educação. Conselho Nacional de Educação. Parecer CNE/CEB no 11 , de 7 de julho de 2010. Diretrizes Curriculares Nacionais para o Ensino Fundamental de 9 (nove) anos. Disponível em <http://portal.mec.gov.br/index.php> Acesso em 25/09/2012. (2010a)

. Ministério da Educação Conselho Nacional de Educação. Parecer CNE/CEB n ${ }^{\circ} 18$, de 15 de Setembro de 2005. Orientações para matrícula das crianças de seis anos de idade no ensino fundamental obrigatório, em atendimento à Lei ${ }^{\circ} 11.114$, de 16 de maio de 2005, que altera os arts. $6^{\circ}, 32$, e 87 da Lei $\mathrm{n}^{\circ}$ 9.394/1996. Disponível em $<$ http://portal.mec.gov.br/index.php $>$ Acesso em 25/09/2012. (2005c)

. Ministério da Educação. Conselho Nacional de Educação. Parecer CNE/CEB no 24, de 15 de setembro de 2004. Estudos visando ao estabelecimento de normas nacionais para a 
ampliação do ensino fundamental para nove anos de duração. Disponível em

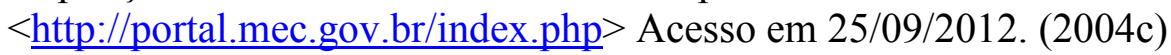

Ministério da Educação. Conselho Nacional de Educação. Parecer CNE/CEB n ${ }^{\circ} 4$, de 20 de fevereiro de 2008. Orientação sobre os três anos iniciais do ensino fundamental de nove anos. Diário Oficial da União, Brasília, DF, 10/06/2008. Disponível em $<$ http://portal.mec.gov.br/index.php $>$ Acesso em 25/09/2012 (2008a)

Ministério da Educação Conselho Nacional de Educação. Resolução CNE/CEB nº 3, de 03 de agosto de 2005. Define normas nacionais para a ampliação do Ensino Fundamental para nove anos de duração. Diário Oficial da União, Brasília, DF, 08/08/2005, seção 1, p. 27. (2005b)

Ministério da Educação. Conselho Nacional de Educação. Resolução CNE/CEB n n 6 , de 20 de Outubro de 2010. Define Diretrizes Operacionais para a matrícula no Ensino Fundamental e na Educação Infantil. Diário Oficial da União, Brasília, DF, 21/10/2010, Seção 1, p. 17. (2010b)

Ministério da Educação. Secretaria de Educação Básica. Ampliação do ensino fundamental pra nove anos: Relatório do Programa. Brasília: MEC/SEB, 2004b, 8p.

Ministério da Educação. Secretaria de Educação Básica. Ampliação do ensino fundamental pra nove anos: $2^{\circ}$ Relatório do Programa. Brasília: MEC/SEB, 2005d, 4p.

. Ministério da Educação. Secretaria de Educação Básica. Ampliação do ensino fundamental pra nove anos: $3^{\circ}$ Relatório do Programa. Brasília: MEC/SEB, 2006c. 10p.

. Ministério da Educação. Secretaria de Educação Básica. $O$ ensino fundamental de nove anos: orientações gerais. Brasília: MEC/SEB, 2004a, 27p.

Ministério da Educação. Secretaria de Educação Básica. O ensino fundamental de nove anos: orientações para a inclusão da criança de seis anos de idade. Brasília: MEC/SEB, 2006d, 28p.

. Ministério da Educação. Secretaria de Educação Básica. Parâmetros Básicos de Infra Estrutura para instituições de educação infantil. Brasília: MEC/SEB, 2006e, 45p.

. Ministério da Educação. Secretaria de Educação Básica. Passo a passo da implementação do ensino fundamental de nove anos. Brasília: MEC/SEB, 2009a, 28p. 
. Ministério da Educação. Secretaria de Educação Básica. A criança de seis anos, a linguagem escrita e o Ensino Fundamental de nove anos: orientações para o trabalho com a linguagem escrita em turmas de crianças de seis anos de idade. Brasília: $\mathrm{MEC} / \mathrm{SEB}, 2009 \mathrm{c}, 122 \mathrm{p}$.

BUJES, M. I. E. e MARCELLO, F. A. Ampliação do ensino fundamental: a que demandas atende? A que regras obedece? A que racionalidades corresponde? Educação e Pesquisa, São Paulo, v. 37, n 1, p. 53-68, Jan/Abr. 2011.

CAMPOS, M. M. Por que é importante ouvir a criança? A participação das crianças pequenas na pesquisa científica. In: CRUZ, S. H. V. (org.) A criança fala: a escuta de crianças em pesquisas. São Paulo: Cortez, 2008, p. 35-42.

CORREA, B. C. Crianças aos seis anos no Ensino Fundamental: desafios à garantia de direitos. In: REUNIÃO ANUAL DA ASSOCIAÇÃO NACIONAL DE PÓS-GRADUAÇÃO E PESQUISA EM EDUCAÇÃO, 30, 2007, Caxambu. Anais.... Caxambu: ANPEd, 2007. Disponível em: <http://www.anped.org.br> Acesso em: 25/09/2012

Educação Infantil e Ensino Fundamental: desafios e desencontros na implantação de uma nova política. Educação e Pesquisa, São Paulo, v.37, n1, p. 105-120, Jan/Abr. 2011.

Ensino Fundamental de nove anos: análise de uma experiência no interior do estado de São Paulo. In: REUNIÃO ANUAL DA ASSOCIAÇÃO NACIONAL DE PÓSGRADUAÇÃO E PESQUISA EM EDUCAÇÃO, 33, 2010. Caxambu. Anais.... Caxambu: ANPEd, 2010. Disponível em: <http://www.anped.org.br> Acesso em: 30/09/2012.

CURY, C. R. J. Estado e políticas de financiamento em educação. Educacão e Sociedade, Campinas, v. 28, n. 100, p. 831-855, out. 2007.

GUIMARÃES, J. L.; PINTO, J. M. R. A Demanda pela educação infantil e os recursos disponíveis para o seu financiamento. Em Aberto, Brasilia, v.18, n.74, p.92-105, dez. 2001.

JACOMINI, M. e KLEIN, S. Qualidade da educação e Ensino Fundamental de nove anos: algumas reflexões. Revista @mbienteeducação, São Paulo, v. 2, n.1, p. 75-92, jan./jul. 2010.

JACOMINI, M. A.; SOUZA, N. A. e KLEIN, S. B. Articulação do debate entre a qualidade de ensino e a implantação do ensino fundamental de nove anos. 2009. In: VII Semana de Educação da Faculdade de Educação da Universidade de São Paulo, 2009. Anais... São Paulo, 2009.

KLEIN, S. B. Ensino fundamental de nove anos no município de São Paulo: um estudo de caso. 2011. Dissertação (Mestrado em Educação) - Faculdade de Educação, Universidade de 
São Paulo, São Paulo, 2011, 233p.

MARIN, A. P. e PANSINI, F. O ingresso de crianças de 6 anos no ensino fundamental: uma pesquisa em Rondônia. Educação e Pesquisa, São Paulo, v.37, n1, p. 87-103, Jan/Abr. 2011.

OLIVEIRA, R. P. Da universalização do ensino fundamental ao desafio da qualidade: uma análise histórica. Educação e Sociedade, Campinas, v. 28, n 100, p. 661-690, out. 2007.

PARO, V. H. Administração Escolar: Introdução crítica. São Paulo: Cortez, 2001.

Educação para a democracia: o elemento que falta na discussão da qualidade do ensino. In: REUNIÃO ANUAL DA ASSOCIAÇÃO NACIONAL DE PÓS-GRADUAÇÃO E PESQUISA EM EDUCAÇÃO, 23, 2000, Caxambu. Anais... Caxambu: ANPEd, 2000. Disponível em: <http://www.anped.org.br>. Acesso em: 25/09/2012. 1998.

Gestão da escola pública: a participação da comunidade. 2 ed. São Paulo: Ática, . Gestão escolar, democracia e qualidade do ensino. São Paulo: Ática, 2007.

PINTO, J. M. de R. A política recente de fundos para o financiamento da educação e seus efeitos no pacto federativo. Educação e Sociedade, Campinas, v. 28, n. 100, p. 877-897, out. 2007.

RIBEIRO, T. A. A implementação do ensino fundamental de nove anos na rede estadual de São Paulo: um estudo de caso. 2011, 212p. Trabalho de Conclusão de Curso (Pedagogia) - Faculdade de Educação, Universidade de São Paulo, São Paulo, 2011.

RISOPATRON, V. E. EL Concepto de calidad de La educación. Santiago do Chile: Unesco: Orealc, 1991.

SÃO BERNARDO DO CAMPO. Disponível em: $<$ http://www.educacao.saobernardo.sp.gov.br/index.php/> Acesso em: 13/05/2011. (2011a)

Histórico. Disponível em: <http://www.saobernardodocampo.org/> Acesso em: 13/05/2011. (2011b)

Secretaria Municipal de Educação. Conselho Municipal de Educação. Deliberação 
CMED $\mathrm{n}^{\mathrm{o}}$ 3, de 01 de janeiro de 2007. Dispõe sobre a transferência de alunos de outros Sistemas de Ensino para o Sistema Municipal de Ensino Fundamental de São Bernardo do Campo. Disponível em: <http://www.educacao.saobernardo.sp.gov.br/> Acesso em: 12/04/2011.

. Secretaria Municipal de Educação. Conselho Municipal de Educação. Deliberação $\overline{C M E D}^{\circ}$ 4, de 17 de dezembro de 2009. Dispõe sobre a implantação do Ensino Fundamental de nove anos de duração, no Sistema Municipal de Ensino, nos termos do art. 208, da Constituição Federal, de 5 de outubro de 1988 e da Lei Federal n ${ }^{\circ}$ 9.394, de 20 de dezembro de 1996. Disponível em: <http://www.educacao.saobernardo.sp.gov.br/> Acesso em: 12/04/2011. (2009b)

. Secretaria Municipal de Educação. Conselho Municipal de Educação. Parecer CMED $\mathrm{n}^{\mathrm{o}} 13$, de 25 de novembro de 2010. Aprova critérios relativos ao ingresso no primeiro ano do Ensino Fundamental, de acordo com a Resolução CNE/CEB n ${ }^{0}$ 6, de 20 de outubro de 2010.

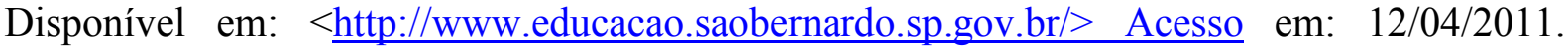
(2010b)

. Secretaria Municipal de Educação. Ensino Fundamental de nove anos. SÃO BERNARDO DO CAMPO: SME, 2009a, s/p.

Secretaria Municipal de Educação. Orientações para a implantação do ensino fundamental de 9 anos. São Bernardo do Campo: SME, 2010a, 19p.

SÃO PAULO. Saresp. Disponível em: <http://www.educacao.sp.gov.br/index.php/> Acesso em: $28 / 09 / 2012$

Secretaria Esadual de Educação. Conselho Estadual de Educação. Deliberação CEE $\overline{n^{\circ}} 61$, de 29 de novembro de 2006. Fixa normas sobre a implantação do ensino fundamental de nove anos no sistema de ensino do estado de São Paulo. Diário Oficial do Estado de São Paulo, São Paulo, SP, 01/12/2006, Seção 1, p. 17. (2006a)

Secretaria Esadual de Educação. Conselho Estadual de Educação. Deliberação CEE $\mathrm{n}^{\mathrm{o}} 73$, de 2 de abril de 2008. Regulamenta a implantação do ensino fundamental de nove anos, no âmbito do sistema estadual de ensino conforme o disposto na Emenda Constitucional $\mathrm{n}^{\mathrm{o}} 53$ e na Lei $\mathrm{n}^{\circ}$ 9.394/96, com as alterações procedidas pela Lei $\mathrm{n}^{\circ} 11.274 / 06$. Diário Oficial do Estado de São Paulo, São Paulo, SP, 03/04/2008, Seção 1, p. 19. (2008a)

Secretaria Esadual de Educação. Conselho Estadual de Educação. Indicação CEE $\mathrm{n}^{\circ}$ 52, de 09 de novembro de 2005. Ampliação do ensino fundamental para nove anos. Disponível em: < http://www.ceesp.sp.gov.br/> Acesso em: 25/09/2012. 
Secretaria Esadual de Educação. Conselho Estadual de Educação. Indicação CEE $\overline{n^{\circ}}$ 63, de 29 de novembro de 2006. Implantação do ensino fundamental de nove anos. Disponível em $<$ http://www.ceesp.sp.gov.br/> Acesso em: 25/09/2012. (2006b).

Secretaria Esadual de Educação. Conselho Estadual de Educação. Indicação CEE

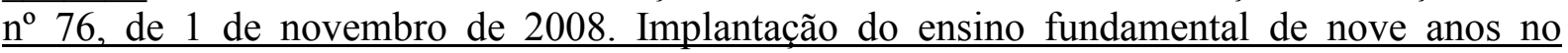
sistema de ensino do Estado de São Paulo. Disponível em <http://www.ceesp.sp.gov.br/> Acesso em 25/09/2012. (2008b).

SARTORIO, L. A. V. O processo de constituição e desenvolvimento da educação no Município de São Bernardo do Campo (1960-2005). In: JORNADA DE EDUCAÇÃO PROMOVIDA PELO GRUPO DE TRABALHO HISTÓRIA, SOCIEDADE E EDUCAÇÃO NO BRASIL, 8, 2008, São Carlos. Anais... São Carlos: Histedbr, 2008. 
APÊNDICES 


\section{APÊNDICE A - Termos de consentimento}

São Paulo, 19 de março de 2010.

Eu compreendo os direitos dos participantes da pesquisa de mestrado intitulada Implementação de políticas públicas: um estudo de caso sobre a ampliação do ensino fundamental para nove anos no município de São Bernardo do Campo, orientado pela Profa. Lisete R. G. Arelaro e que tem Lara Gonzalez Gil como pesquisadora responsável da Faculdade de Educação da Universidade de São Paulo, que podem ser contactadas pelo email liselaro@usp.br/lara.gil@usp.br ou telefone (11) 8366-6649/5679-6847.

$\mathrm{Na}$ qualidade de responsável por esta instituição autorizo a participação na pesquisa dos professores e dos alunos do $1^{\circ}$ ano do ensino fundamental de nove anos, bem como da coordenação pedagógica da Unidade Escolar.

Compreendo como e porquê este estudo está sendo feito. Os responsáveis pela pesquisa garantem o sigilo que assegure a privacidade dos sujeitos quanto aos dados envolvidos na pesquisa. Receberei uma cópia assinada deste formulário de consentimento.

Diretora da Unidade Escolar 
São Paulo, 19 de março de 2010.

Concordo em participar, como voluntário, do projeto de pesquisa de mestrado intitulada Implementação de políticas públicas: um estudo de caso sobre a ampliação do ensino fundamental para nove anos no município de São Bernardo do Campo, orientado pela Profa. Lisete R. G. Arelaro e que tem Lara Gonzalez Gil como pesquisadora responsável da Faculdade de Educação da Universidade de São Paulo, que podem ser contactadas pelo email liselaro@usp.br/lara.gil@usp.br ou telefone (11) 8366-6649/5679-6847.

O presente trabalho tem por objetivo geral analisar a implementação do Ensino Fundamental de nove anos em uma escola da rede municipal de São bernardo do Campo, verificando a articulação da política educacional nacional, sua adequação em nível municipal e sua realização no cotidiano da unidade escolar, neste período de ajuste à uma nova organização do Ensino Fundamental.

Minha participação consistirá em autortização da observação da regência de aulas, conversas informais e concessão de entrevista semi-estruturada. Compreendo qwue este estudo possui finalidade de pesquisa, que os dados obtidos serão divulgados seguindo as diretirzes éticas da pesquisa, com a preservação do anonimato dos participantes, assegurando, assim minha privacidade. Sei que posso abandonar a minha participação na pesquisa quando quiser e que não receberei nenhum pagamento por esta participação.

Professora da Unidade Escolar 


\section{Pais/mães/responsáveis}

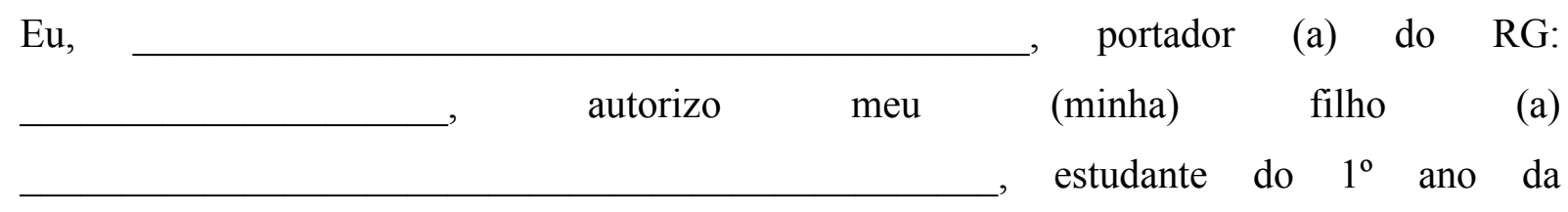

, a participar de uma entrevista (que será filmada e utilizada para elaboração do Relatório Final de pesquisa), a ser realizada no dia , sobre o ensino fundamental de nove anos, com as professoras Lara Gonzalez

Gil e Sandra Cristina Lima da Silva, responsáveis pela pesquisa do Projeto "O Ensino Fundamental de Nove Anos no Estado de São Paulo: um estudo exploratório sobre sua implementação" na escola.

São Paulo, de de 2010.

Assinatura do Responsável 


\section{Apêndice B - Roteiros de entrevistas}

\section{Professores(as)}

\section{Formação e carreira}

1) Qual é a sua formação?

2) Há quanto tempo você trabalha no magistério? Qual a sua situação funcional nessa rede de ensino?

3) Você já trabalhou com primeira série? Com primeiro ano? Com a educação infantil?

4) Você escolheu trabalhar com primeiro ano? Por quê?

5) Quais expectativas você tinha com esta nova organização de ensino?

\section{Democratização do ensino}

6) O que você acha do ensino fundamental de nove anos? Ele contribui para a democratização do ensino? Por quê?

7) Em sua opinião, por que o governo ampliou o ensino fundamental para nove anos?

\section{Qualidade do ensino}

8) Como foi a reação das crianças ao chegarem à esta escola de ensino fundamental?

9) Quais foram as orientações que você recebeu para trabalhar com as crianças de seis anos no ensino fundamental? Você recebeu algum material didático para o desenvolvimento de atividades com os $1^{\circ}$ anos e/ou algum documento de orientação para este trabalho? Você utiliza estes materiais? Como?

10) Que mudanças foram realizadas na escola para receber as crianças de seis anos? Essas mudanças atendem as necessidades das crianças nessa faixa etária?

11) Houve mudança no espaço físico da escola para receber as crianças de seis anos? Quais?

12) O trabalho com as crianças de seis anos está articulado ao planejamento dos demais anos do primeiro ciclo do ensino fundamental? 
13) O que é trabalhado no primeiro ano? As crianças estão sendo alfabetizadas? Como é realizada a alfabetização da criança de seis anos?

14) De acordo com sua experiência, o trabalho com as crianças de seis anos está mais próximo daquele que era desenvolvido na pré-escola ou daquele que era, normalmente, desenvolvido com as antigas $1^{\mathrm{a}}$ séries?

15) Você acha que as necessidades das crianças de seis anos são melhores atendidas na escola de ensino fundamental ou na escola de educação infantil? Por quê?

16) Como é a rotina das crianças do $1^{\circ}$ ano? Há brincadeiras? Quais? Com que frequência? Em quais espaços da escola as crianças realizam estas brincadeiras? Em sala de aula, elas brincam? Elas trazem brinquedos de casa? Como isso funciona dentro da sala de aula?

17) Que mudanças você observa em seus alunos do começo do ano para cá? E no que se refere à aprendizagem, os alunos estão acompanhando as aulas? Eles estão correspondendo aos objetivos propostos e as suas expectativas? Quais são os objetivos do primeiro ano? Houve alguma orientação dos órgãos centrais sobre os objetivos do primeiro ano?

18) Como você realiza a avaliação da aprendizagem dos alunos?

19) Os professores dos primeiros anos realizam um trabalho coletivo? Por quê? Como esse trabalho é realizado?

20) Quais dificuldades você tem encontrado na realização do trabalho com as crianças do primeiro ano do ensino fundamental? Por quê?

21) Há formação continuada para os professores do primeiro ano do ensino fundamental? Como é realizada? Você tem acesso? Participa? Qual a sua opinião sobre estas formações? Elas ajudam você? Como?

\section{Gestão democrática}

22) Como você tomou conhecimento da legislação que implantou o ensino fundamental de nove anos? Você participou de alguma discussão sobre esse tema? Onde? Quando?

23) Como a proposta de ensino fundamental de nove anos foi discutida em sua escola? Você participou? Você foi consultada sobre o ensino fundamental de nove anos? Por quem? Quando? Sua opinião foi levada em conta na implementação da proposta?

24) Quais segmentos da comunidade escolar foram chamados a discutir a implementação do ensino fundamental de nove anos? 
25) A implementação do ensino fundamental de nove anos foi discutido no Conselho de Escola?

26) Em quais momentos são discutidas as questões relativas ao ensino fundamental de nove anos? Nas reuniões pedagógicas ou HTPC's são discutidos assuntos referentes ao ensino fundamental de nove anos? Somente os professores dos $1^{\circ}$ anos discutem sobre isso ou os demais professores também participam e opinam?

27) O ensino fundamental de nove anos foi discutido com as crianças? Você conversou com elas sobre isso? Existem espaços de participação para elas dentro da escola? As crianças foram consultadas sobre o ensino fundamental de nove anos e suas novas rotinas? Como são estas rotinas? Você fez algum "combinado" com elas? Quais foram?

\section{Gestores(as)}

\section{Formação e carreira}

1) Qual é a sua formação?

2) A formação adquirida possibilitou atuar com eficácia diante da realidade da escola?

3) Há quanto tempo atua como coordenadora/diretora/vice?

4) Já trabalhou com Educação Infantil? Quando tempo?

5) O trabalho desenvolvido com educação infantil contribuiu de alguma forma para o trabalho que realiza atualmente?

6) Já trabalhou com Ensino Fundamental? Quanto tempo?

7) Porque escolheu o magistério?

\section{Democracia do ensino}

8) Você concorda com o ensino de nove anos? Como você foi informada sobre Ensino Fundamental de 9 anos? Justifique.

9) Você compreende como necessário os alunos iniciarem o ensino mais cedo?

10) O que você espera dessa ampliação do Ensino Fundamental?

\section{Qualidade do ensino}


11) Como foram compostas as turmas?

12) A escola possui infraestrutura para receber essas crianças?

13) Quais foram as modificações feitas? Houve a preocupação na criação ou adaptação dos cantinhos lúdicos? Quais? Qual a importância?

14) Como foi a reação das crianças ao chegarem à escola?

15) A alfabetização é um dos objetivos do $1^{\circ}$ ano? Por quê?/ Explique.

16) Houve a preocupação na criação ou adaptação dos cantinhos lúdicos? Quais? Qual a importância?

17) Você participou de cursos sobre o tema? Quais as pessoas que participarão além de você?

18) Qual é o critério utilizado para a avaliação da aprendizagem dos alunos?

19) Os professores receberam material didático específico?

\section{Gestão democrática}

20) Você recebeu orientações da Secretaria da Educação sobre o ensino de 9 anos?

21) Houve um esclarecimento sobre o ensino de 9 anos para os pais? Qual a posição deles?

22) Qual é o posicionamento dos professores em relação à ampliação do Ensino Fundamental?

23) A proposta sobre o Ensino Fundamental de 9 anos e as orientações foram discutidas na escola? Quem participou? Em que momento?

24) No primeiro ano de execução do Ensino Fundamental houve alguma ligação entre o Estado e o Município para o atendimento das crianças chegando a um acordo sobre qual escola assumiria o $1^{\circ}$ ano?

\section{Pais/mães/responsáveis}

\section{Caracterização}

1) Você mora próximo à escola? Qual é o nome do seu bairro?

2) Quantos filhos você tem? Quantos estudam nesta escola? 
3) Até que série você estudou?

\section{Democratização do ensino}

4) Você concorda que seu filho com 6 anos de idade esteja obrigatoriamente no ensino fundamental? Por quê?

5) Qual é a sua opinião a respeito da ampliação do ensino fundamental para 9 anos?

6) Essa nova medida diminui a Educação Infantil em um ano. Você concorda com essa mudança? Por quê?

7) Em sua opinião, por que o governo ampliou o ensino fundamental para nove anos?

\section{Qualidade de ensino}

8) O seu filho cursou a educação infantil (pré-escola)? Que diferenças você percebe entre a educação infantil (pré-escola) e escola atual?

9) O que você acha da escola do seu filho?

10) Em sua opinião o que é uma escola boa?

11) Que mudanças você acha necessárias para atender melhor as crianças de seis anos de idade?

12) O que você espera do trabalho realizado com seu filho nesta nova série inicial?

13) Você está contente com seu filho no $1^{\circ}$ ano do ensino fundamental ou você preferiria que ele estivesse na educação infantil? Por quê?

14) Como você acha que seu filho está sentindo no $1^{\circ}$ ano? Ele está feliz com esta mudança?

\section{Gestão democrática}

15) Você escolheu matricular seu filho nesta escola? Como foi este processo?

16) Se você pudesse escolher matricularia seu/sua filho/filha de seis anos na Educação Infantil ou no Ensino Fundamental? Por quê?

17) Você recebeu alguma orientação sobre a entrada de seu filho de 6 anos no ensino fundamental de 9 anos? 
18) Você conhece o projeto pedagógico da escola? Participou de alguma discussão sobre sua elaboração?

19) Você conhece a proposta de trabalho para o $1^{\circ}$ ano? Participou da elaboração desta proposta? Em que momento?

\section{Grupos de crianças}

\section{Dinâmica da entrevista}

a) Apresentação da pesquisadora, do motivo da entrevista, e consentimento das crianças para registrar e contar para outras pessoas as coisas que eles disserem.

b) Apresentação dos equipamentos de filmagem e gravação - explicação de que aquilo servirá pra não esquecer nada do que eles falarem.

c) Solicitação às crianças para que se apresentem, dizendo o seu nome e a respectiva idade

d) Contar a História : "Era uma vez um menino chamado Sebastião. O Sebastião era um menino de 6 anos, que morava numa cidade muito longe daqui. Um dia, a mamãe do Sebastião resolveu que iria se mudar para São Paulo e pensou que teria que colocá-lo na escola. Sebastião ficou um pouco nervoso, porque como ele morava longe, ele não sabia como era a escola que ele ia estudar, e ficava todo dia sonhando com essa escola, pensando no que ia ter, no que se fazia nessa escola."

e) Fazer a seguinte intervenção: "Vamos ajudar o Sebastião? Se ele viesse estudar nessa escola, como a gente poderia contar para ele como é aqui?"

\section{Questões norteadoras}

1) Como é a escola? O que tem aqui?

2) O que vocês fazem nessa escola? O que vocês fazem que vocês acham mais legal? E o que vocês fazem que vocês não gostam?

3) Se vocês pudessem mudar alguma coisa nessa escola, o que mudariam?

4) Vocês acham que as crianças de seis anos, assim como vcs e o Sebastião, devem ir para escola, de qualquer jeito? Por quê? 
5) E como é uma escola boa para as crianças de seis anos? O que deve ter? O que as crianças devem fazer nessa escola?

6) Alguns de vocês já foram a outras escolas, não foram? Como era lá? O que tinha? O que faziam? O que não tinha?

7) Vocês sabiam que até pouco tempo atrás, crianças do tamanho de vocês ainda ficavam ou em casa ou na escola de educação infantil? (Emei, creche, prezinho). E alguns homens resolveram que era melhor para vocês estudarem já na escola das crianças grandes? O que vocês acham disso? Acham que é melhor para vocês já estudarem nessa escola ou acham que era melhor ficar estudando na escola antiga?

8) Em qual escola a criança de seis anos deve estudar?

Vocês querem fazer um desenho dessa escola em que vocês estudam?

\section{Membros dos Conselhos de Escola}

1) Qual segmento você representa neste Conselho?

2) Há quanto tempo é representante?

3) Você sabe que o ensino fundamental foi ampliado para nove anos de duração e a idade de ingresso foi antecipada para seis anos?

4) A implementação do ensino fundamental de nove anos foi discutida no Conselho de Escola?

5) Houve discussão sobre o ensino fundamental de nove anos com a comunidade escolar?

6) Qual sua opinião sobre o ensino fundamental de nove anos?

7) Você conhece a opinião do segmento que você representa sobre esse assunto?

8) Você sabe que providências foram planejadas e quais foram executadas para a recepção das crianças mais novas e para a organização da unidade escolar, no geral, com essa nova série?

9) Existe algum tipo de acompanhamento, por parte do Conselho de Escola, sobre a adaptação das crianças, equipe pedagógica e comunidade ao ensino fundamental de nove anos? Se sim, como ele é feito?

\section{Secretária de Educação}

Nome: 
Tempo que está no cargo:

Formação:

1) A Sra. poderia nos contar como foi o processo de implantação do ensino de 9 anos neste Município/Estado? Considere: quando foi implantado, objetivos e critérios definidos; justifique, em especial, a opção por retardar ou antecipar a implantação do ensino fundamental de 9 anos.

2) Em relação à demanda escolar, a sua rede de ensino conseguiu atender a todas as crianças na $1^{\mathrm{a}}$ série? E como foram acomodadas as crianças da educação infantil? Como está organizada hoje a sua rede para esse atendimento?

3) A Sra. considera que esta nova organização do ensino fundamental será/ está sendo mais interessante para as crianças e o processo pedagógico? Por quê?

4) A rede sob sua responsabilidade estava preparada para receber as crianças com idades de seis anos e menos?

5) O que efetivamente mudou/vem mudando na sua rede de ensino com esta nova organização?

6) Quais os planos e projetos da sua Secretaria para implementar esta nova organização nos próximos anos?

7) O que a Sra. considera que seria preciso implementar na sua rede de ensino para que os objetivos desta implantação possam efetivamente ser atingidos?

8) Os professores receberam/vêm recebendo formação/ orientação específica para trabalhar com esta nova turma? Por meio de que materiais ou cursos?

9) E os pais/ responsáveis como ficaram sabendo e como se manifestaram sobre esta nova organização do ensino?

10) E a Sra. acha que eles estão suficientemente esclarecidos(as) sobre as mudanças?

11) Qual sua posição sobre a matrícula de crianças menores de seis anos de idade na rede de ensino? A Sra. acredita que os governos municipais/estadual poderiam definir com rigorosidade a idade mínima para essa matrícula?

12) E a obrigatoriedade de matrícula de todas as crianças, a partir de 4 anos de idade (EC $\left.n^{\circ} .59 / 2009\right)$ pode alterar alguma dinâmica da atual organização escolar?

13) A Sra. considera que as crianças estão mais felizes na escola fundamental do que se estivessem fazendo este ano nas escolas de educação infantil? 
14) A Sra., particularmente, acha que é positivo acelerar-se/ adiantar o processo de letramento e alfabetização das crianças? Por quê?

15) A Sra. considera viável/ possível / desejável que todas as crianças brasileiras estejam alfabetizadas aos 8 anos de idade, avaliadas pelo SARESP ou Provinha Brasil?

16) Na sua rede, os Conselhos de Escola têm um papel definidos no projeto pedagógicos das escolas? Eles discutiram a nova organização escolar?

17) Quantas escolas de sua rede (aproximadamente...) solicitaram recursos complementares visando realizar projetos diferenciados com estas crianças menores?

18) Se a Sra. como mãe ou como gestora pudesse escolher manteria seus filhos/ as crianças nas escolas de educação infantil?

19) Houve alguma solicitação das escolas ou recomendação da sua área pedagógica para redução do número de alunos nestas séries/anos iniciais?

20) Há projetos experimentais/ especiais de funcionamento destes anos iniciais na sua rede de ensino? Quantos, aproximadamente?

21) A Sra. acredita que o ensino das séries/anos seguintes será mais ativo/interessante/ lúdico com a introdução desta nova série/ ano? Por que? 


\section{APÊNDICE C - Transcrições das entrevistas}

\section{Entrevista com Professora 1}

Lara - Qual é a sua formação?

Professora - Eu fiz Magistério e depois fiz Pedagogia na Universidade Metodista.

Lara - Há quanto tempo você trabalha no magistério?

Professora - Eu trabalho desde os quinze, na verdade, na época em que eu estava no colégio já tive pretensão, mas comecei em escolas pequenas perto de casa, escolinhas de bairro. Depois fiz o colégio e no segundo ano do colégio eu desisti do colégio e decidi seguir a carreira do magistério. Perdi o que eu tinha feito e vim fazer o técnico do magistério.

Lara - Qual é sua situação funcional nesta rede de ensino?

Professora- Fez sete anos agora em junho, porque eu sou de 2003.

Lara - E, você é efetiva?

Professora - Sou efetiva. Nesta rede efetiva e depois eu tenho na de São Paulo, também há três anos.

Lara - E, você já trabalhou com a primeira série?

Professora - Todos os anos em que estive aqui, exceto no meu primeiro ano que eu peguei a terceira série. Aí no ano seguinte, já...

Lara - Nesta escola?

Professora - Nesta escola, eu entrei na rede já nesta escola. Era uma sala de terceira série que tinha ocorrido alguns problemas e precisavam de uma professora efetiva para pegar a sala para não deixar. Então eu peguei esta terceira em junho e no ano seguinte primeira, de lá para cá com sempre com primeira série.

Lara - E com o primeiro ano fundamental de nove anos, você já trabalhou em outro lugar?

Professora - Não, este é o primeiro ano porque este é o primeiro ano que está entrando na rede, porque nos outros anos ainda era ensino de oito anos.

Lara - E você já trabalhou com Educação Infantil?

Professora - Já trabalhei na escolinha que comecei, era Educação Infantil. E lá sempre trabalhei com os pequenos. Trabalhei lá, 9 anos. Aí depois fui para o Colégio Metodista, tive uma experiência com meninos um pouco maiores, lá, mas no infantil mesmo só no particular. Agora que eu estou com o infantil na prefeitura de São Paulo, porque é EMEI lá.

Lara - Nestes três anos que você trabalhou em SP foi com o infantil? 
Professora - Foi com o infantil.

Lara - E, você que escolheu trabalhar com o primeiro ano neste ano?

Professora - É assim, como a parceria que eu e a outra professora fazemos já tem dado certo há alguns anos e quando a diretora soube da notícia da implementação aqui na escola, ela veio conversou com a gente e a gente abraçou a idéia por já fazer parcerias em anos anteriores iria facilitar porque eu acho que juntou o útil ao agradável a gente gostar e a Ana confiar no nosso trabalho.

Lara - E, quais as expectativas que vocês tinham diante deste trabalho com o primeiro ano? Professora - Eu achei que a gente ia ter um suporte um pouco maior da secretaria e isso não aconteceu, porém, é aquilo que eu te falei, como nos anos anteriores eu já havia tido experiências boas com alfabetização nesta comunidade então a gente adaptou muito o nosso trabalho para se adequar a esta nova rotina. Na verdade a rotina é que foi diferenciada. Mas, eu achei que se a gente tivesse tido mais suporte, poderia ter sido melhor o trabalho. Apesar de que avaliando o trabalho agora no final do ano percebemos que o trabalho foi bom diante do que podíamos fazer e do que a gente recebeu. Acho complicado assim, estamos dentro de uma estrutura de fundamental, uma estrutura que não ajuda o trabalho com a educação infantil, é uma escola que precisa ser remodelada para aceitar crianças menores e a partir do ano que vem serão crianças menores ainda chegando aqui no colégio que terão quatro anos, utilizando o mesmo prédio. Essa adaptação tem que ser repensada pra ontem, porque este tipo de criança não consegue ficar 5 horas dentro da sala de aula, então a gente repensou uma rotina para adequar a isso mesmo, por que eles não tem..., nós adultos não temos, eles menos ainda...

Lara - E o que você acha do Ensino fundamental de nove anos? Você acha que ele contribuiu para a democratização do ensino?

Professora - Eu penso assim, como nós havíamos em anos anteriores crianças da EMEI aqui do lado, já tínhamos algumas dificuldades para adaptar estas crianças à nossa rotina para alfabetizar porque nós somos alfabetizadores apesar de que entre aspas não é obrigado a alfabetizar neste primeiro ano porque agora é um ciclo inicial com três anos para concluir a alfabetização. Ajuda as crianças a se adaptarem melhor a esta rotina do fundamental que para mim é uma questão importante porque as crianças precisam de uma linha tempo de atividades diferenciadas para aguentar aqui cinco horas. Atende aquelas crianças que não tem nenhum acesso à leitura, nenhum acesso material a suportes de portadores de textos, eles não tem suporte nenhum. As famílias não conseguem ser portadoras de textos em casa ler com os filhos, então nesse sentido sim, deles poderem ter mais contato com leitura e com este mundo 
letrado e a gente sabe que é pra ter um número maior de crianças no fundamental e a gente sabe que o repasse de verba também é maior do governo para o município, então acho que isso pesa um pouco também nesse sentido.

Lara - Então nacionalmente você concorda nesse sentido da cultura escrita

Professora - É, na nossa realidade aqui. Numa realidade que as crianças não têm este acesso. Lara - No caso de São Bernardo?

Professora - É no nosso caso aqui, eu estou dizendo do Battistini. Porque eu já fui coordenadora em escolas do centro onde a realidade é outra, não é. Que não se compara, porque indo de bairro a bairro a caracterização é diferente, o acesso à leitura e à escrita é diferente e aqui a leitura e a escrita é muito difícil, os pais pouco colaboram nesse sentido, de poder subsidiar os alunos naquele contato com leitura e escrita. Esses alunos entrando no fundamental ajuda a criar este aluno mais leitor, mais participativo, não é?

Lara - Mas, pensando no Brasil você concorda com a lei ou não?

Professora - É, acho que é uma questão que se a gente tivesse como adequar os espaços, adequar a rotina, adequar o repasse de verbas para as escolas para que os materiais pudessem chegar mais rápido na nossa mão eu digo que sim, porque é tudo um ganho. A gente conhece crianças do ensino particular, ensino privado que estão na educação e com quatro e cinco anos já sabem ler e escrever, não é? Se você fosse pensar que tivesse uma adequação de tudo isso, que a gente sabe que é uma coisa que a escola dá conta eu acredito que sim. É legal porque a gente sabe que as crianças aprendem, sendo estimulados eles aprendem.

Lara - E, em sua opinião, porque você acha que o governo ampliou?

Professora - Eu acho que é por conta deste repasse de verbas, porque a gente acaba recebendo mais porque são nove anos que a criança fica no ensino fundamental é fundamental, é obrigado a frequentar. Acho que é por isso.

Lara - E qual foi a reação das crianças ao chegarem nesta escola?

Professora - Como algumas já vinham daqui e tinham 5 anos, mas algumas vieram ou transferidas, enfim, não é? Esta rotina de cinco horas precisou ser reestruturada porque não conta mesmo. Cinco horas em sala de aula só com atividades de caderno, lousa, pior que a gente é, por conta desta parceria que eu e a outra professora fazemos já há muito tempo agente já pensou que o portfólio agora, né, terminamos de montar o portfólio com umas fotos de todos os eventos diferenciados que fizemos desde o começo do ano, mês a mês, onde a gente propôs uma atividade mais diversificada, um pouco diferente das que eles tinham até, então. Então assim, as crianças mostram para nós que tem coisas que não dá, que temos que repensar, até em relação ao comportamento. $\mathrm{O}$ comportamento diz muito se a rotina está 
agradando ou não, mas para eles, por conta do tamanho do prédio, para eles aqui é um shopping, vamos dizer assim, aqui é um espaço onde eles podem correr, brincar, e a diferença é que às vezes em casa a mãe, não deixa sair do portão. Então aqueles que vieram novos para cá, é tudo muito novo. Aqueles que já estavam inseridos na rotina já se adaptaram um pouco melhor

Lara - Os outros tiveram um pouco mais de dificuldade?

Professora - É acredito que sim, porque a EMEI de onde eles vieram era menor. Aqui o prédio acaba agrupando um número maior de crianças fica diferente, mas depois eles já se adaptaram.

Lara - E quais foram as orientações que você recebeu para trabalhar com as crianças de seis anos? Veio algum material didático, um documento de orientação?

Professora - Então nós não recebemos nada pronto, como eu falei, por ter experiência de anos anteriores e a gente sempre trabalhou na produção do PPE da escola eu e a outra professora. A gente sempre participou das discussões, então assim, facilitou pela experiência que nós tínhamos em criar o nosso currículo, nós da manhã e as duas professoras da tarde, elaboramos juntas este currículo porque não existia nada pronto, não recebemos nada que dissesse nós queremos isso, isso e isso, nós criamos a partir do que tínhamos como experiência de termos já trabalhado com primeira e adaptamos esta rotina das brincadeiras, colocando uma quantidade maior de horas para eles brincarem, mas não veio material, apostila, nada disso. Nós criamos e desenvolvemos durante o ano.

Lara - E não teve nenhuma reunião?

Professora - Não, não. Para dizer assim, se teve eu desconheço. Nós não participamos de nenhuma, Nos foi feita a proposta de trabalhar com estas crianças, nós aceitamos e colocamos as caras. Mas, para mim, uma discussão de currículo, não houve nada disso.

Lara - E, que mudanças mais foram realizadas na escola?

Professora- Então, a implantação da brinquedoteca já era uma discussão de anos anteriores e foi efetivada. O departamento mandou os brinquedos, uma coisa que foi conquistada neste ano e a adequação das mesinhas que até então eram individuais e a diretora conseguiu solicitar as mesinhas para quatro crianças para as crianças trabalharem em grupo. De estrutura mesmo estas duas modificações foram as mais específicas, mas ainda necessita de muita adequação de banheiro, de pia, porque estas crianças são menores.

Lara - E, você acha que estas mudanças atendem as necessidades das crianças?

Professora - Então da brinquedoteca é imprescindível, porque eles necessitam de um tempo maior para brincar e de um espaço para organizar este material também, até o uso coletivo do 
material eles podem aprender, porque daqui para frente a gente vai seguir com eles e, na nossa rotina, tanto que a brinquedoteca é um momento diário, e tem dia que a gente adéqua, tem dias que eles estão em outro momento na sala de aula com brincadeiras lúdicas para alfabetizar e neste dia a gente deixa de ir para a brinquedoteca, então ter este espaço na rotina fica a critério do nosso planejamento semanal vir ou não na brinquedoteca, mas que auxilia $1000 \%$, porque como eu falei tem horas que eles não querem mais trabalhar, efetivamente escrever, enfim, não é? Tem aquelas horas que eles estão lendo, mas tem horas que a gente sabe que não dá. Não que a brinquedoteca seja uma espaço para relaxar, mas a brinquedoteca é um espaço que além do lúdico, das brincadeiras simbólicas auxiliam na alfabetização.

Lara - O trabalho com as crianças de seis anos está articulado com o planejamento das crianças dos demais anos do primeiro ciclo?

Professora - Então, como eu falei que a gente já havia trabalhado com o primeiro ano nos anos anteriores o que nós percebemos assim, nós não sentamos, nós do antigo primeiro ano e as do segundo ano. Isso não foi realizado, sabe, mas como nós já temos conhecimento do que era o ciclo por conta da nossa experiência anterior, nós adequamos este conteúdo para ele ficar, vamos dizer assim, mais elástico, para atender às crianças de seis anos. Mas, não houve nenhuma reunião específica para que nós pudéssemos sentar e discutir...

Lara - As outras professoras do primeiro ciclo participaram da discussão?

Professora - Não, não. Tanto que este currículo de primeiro ano do fundamental de nove anos foi discutido entre as professoras eu e as outras professoras do primeiro ano do fundamental de 9 anos.

Lara - As professoras da educação infantil participaram?

Professora - Não. Em momento nenhum a gente conseguiu sentar para discutir sobre isso.

Lara - O que é trabalhado no primeiro ano? As crianças estão sendo alfabetizadas? Como é realizada a alfabetização da criança de seis anos?

Professora - Então, na verdade a gente seguiu as orientações no sentido de manter as áreas de conhecimento. Dentro das áreas do conhecimento a língua, a matemática, ciências, história, geografia, educação física e artes e dentro destes eixos fomos fazendo uma interdisciplinaridade, porque é difícil dizer assim, vamos trabalhar só língua hoje agora para e vai para aula de história, com eles não dá para fazer assim. Mesmo porque tem uma rotina, a gente língua, história, geografia e ciência a gente interdisciplinou, matemática fica mais a parte e arte e educação física também. E, a gente acaba caindo na alfabetização, dizer que eles são obrigados a estar alfabetizados no primeiro ano, não. Eles terão três anos para ter esta base, só que como nós já tínhamos a experiência anterior a gente não consegue fugir disso, 
pode ser que um dia possam dizer que eles não precisem estar alfabetizados, porém a gente tem a cobrança bimestralmente como nos outros anos, de quantos alfabéticos, quantos présilábicos.

Lara - Vocês fazem a planilha?

Nós fazemos a planilha. Então isso nos dá, vamos dizer assim, uma obrigação velada de que nós precisamos dar conta do recado também. Eu não acho que não seja certo, porque as crianças tem condições de aprender, de uma maneira mais lúdica, uma leitura de textos, enfim com uma rotina que adéqüe esta alfabetização de uma maneira mais lúdica através de brincadeiras. Mas, então nós fomos pensando no decorrer do ano em atividades como culinária, com atividades que eles pudessem fugir da rotina que a gente sabe que o fundamental tem. Com artes, com o projeto do Romero Britto agora deu esta luz agora no segundo semestre que eles estão empolgados, o material que eles estão produzindo são materiais que mostram que eles gostaram que se adaptaram que a gente propôs para eles. Então assim, a gente tentou dentro da nossa rotina passar atividade e conteúdo de modo que eles fossem dar conta, mas pensando num trabalho mais interdisciplinar, nada muito fechado e na minha opinião este primeiro ano do fundamental de 9 anos não deveria ter uma ficha de rendimento, poderíamos continuar com este primeiro ano com uma ficha descritiva, um relatório individual, apesar de que você vai acabar entrando no que ele atingiu ou não em relação a turma, mas ele é mais descritivo. Você pode dizer que a criança se adaptou à rotina o que na ficha de rendimento não tem, você pode dizer que a criança conseguiu socializar conhecimento o que na ficha de rendimento não tem. Tem questões que através da ficha de rendimentos a gente não consegue dar conta de informar. Não dá para ser tão fechada. Como por exemplo, ali está dizendo que a criança é satisfatória ou insatisfatória, não pode ter um meio termo.

Lara - E essa ficha é da escola ou do município?

Professora - É do município. Porque até então não recebemos orientação nenhuma como no começo, então a gente continuou com aquilo que já sabíamos que é a fícha de rendimentos, apesar de não concordar. Eu acho que poderíamos trabalhar com um relatório. Que daria conta.

Lara - E foi discutido isso?

Professora - Não, não. A gente não teve oportunidade de discutir isso. Embora nos conselhos a gente tenha levantado a necessidade de modificação, se pode ou não aí já está numa instância um pouco maior. 
Lara - De acordo com sua experiência, o trabalho com as crianças de seis anos está mais próximo daquele que era desenvolvido na pré-escola ou daquele que era, normalmente, desenvolvido com as antigas $1^{\mathrm{a}}$ séries?

Professora - Acho que está mais próximo do que é desenvolvido nas primeiras séries, por conta do que eu já falei que a gente sabe que eles precisam ser alfabetizados, mas a gente não consegue pensar só nisso, não pode ser só este o eixo do trabalho. A questão do trabalho com a pré escola que é o brincar, que é o lúdico tem que estar presente o tempo todo. Então a gente faz um pouco dos dois, a gente tenta fazer $50 \%$ de cada. Não tem como, numa escola do ensino fundamental ficar na brincadeira o tempo todo.

Lara -Você acha que as necessidades das crianças de seis anos são melhores atendidas na escola de ensino fundamental ou na escola de educação infantil? Por quê?

Professora - Se é uma escola onde a estrutura física colabora, ela pode vir para o ensino fundamental. Eu acho até que, por exemplo, no infantil não tem a informática, que é um recurso que hoje em dia, por conta da tecnologia as crianças amam, eu acredito que eles podem ser atendidos no fundamental, eu acho que eles ganham bastante, mas pensando numa rotina onde eles possam todos os dias ter garantido o brincar, o lúdico. Eu acho que atender no fundamental e atender na educação infantil precisa de uma estrutura para atender, porque a gente acaba tendo no fundamental se adequar a esta relação de quantos alfabéticos e quantos pré-silábicos, ah você não tem que dar conta disso, então é uma outra situação. Então porque na educação infantil também tem uma cobrança sim porque eles também têm objetivos para serem alcançados, mas pode ser pensando para uma outro final que não seja o alfabetizar. Então acho que nesse sentido modifica um pouco.

Lara - Então você acha que as crianças podem ser melhores atendidas?

Professora - Depende da estrutura da escola, se a escola tem como recebê-los para adequar a rotina o fundamental pode ser o local correto. Agora se não tem a gente acaba tendo que criar condições. Que nem, o que eu e a outra professora fizemos foi criar condições para que eles fossem atendidos aqui da melhor maneira possível, mas agora se no infantil eles tivessem toda esta estrutura eles poderiam ficar lá. Depende da estrutura que a escola tem

Lara - Como é a rotina das crianças do $1^{\circ}$ ano? Há brincadeiras? Quais? Com que freqüência? Em quais espaços da escola as crianças realizam estas brincadeiras? Em sala de aula, elas brincam? Elas trazem brinquedos de casa? Como isso funciona dentro da sala de aula?

Professora - A gente divide nossa rotina de acordo com as áreas de conhecimento, mas eles têm um momento em sala de aula, depois o lanche, depois a higiene, depois o brincar e o momento de saída. Dentro desta atividade em sala de aula, a gente costuma assim, se tem uma 
atividade mais dirigida, de escrita, de matemática, enfim, no segundo momento a gente acaba intercalando com uma brincadeira. Então eles têm outros locais para utilizar, o ateliê, a brinquedoteca, a biblioteca, o laboratório de informática, eles tem acesso a estes outros espaços que estão divididos na nossa rotina. Então cada dia nós utilizamos um destes espaços, a quadra, por exemplo, a gente conseguiu adequar esta rotina para que eles tivessem um momento na sala e este momento fora.

Lara - Geralmente no começo da aula eles fazem mais lição e depois...

É geralmente de escrita, porque a gente acredita que mesmo sendo de manhã eles estão mais tranquilos ainda, eles produzem melhor do que no segundo período depois do intervalo que eles já estão mais agitados. Para fazer algo que necessita que eles fiquem mais concentrados utilizamos a primeira parte do período.

Lara - Que mudanças você observa em seus alunos do começo do ano para cá? E no que se refere à aprendizagem, os alunos estão acompanhando as aulas? Eles estão correspondendo aos objetivos propostos e as suas expectativas? Quais são os objetivos do primeiro ano? Houve alguma orientação dos órgãos centrais sobre os objetivos do primeiro ano

Professora - Então, até estávamos discutindo isso ontem, se esta turma que nós estamos que deveriam estar na educação infantil chegasse para nós que somos da primeira série no ano que vem sendo do primeiro ano do ensino fundamental a gente estaria super feliz, porque muitos deles das duas salas, sendo da manhã, pelo que estamos vendo, já estão lendo e escrevendo. Porque quando eles chegavam para nós sendo do fundamental de 8 anos, nós falávamos se chegarem para nós sabendo o nome e o alfabeto, para nós já está bom porque o resto a gente desenvolve até o final do ano. As crianças vão dar conta de aprender, vamos dizer assim. Daí a gente para e olha isso hoje, nossa mais era tão pouco diante do que eles produziram durante este ano. E isso facilita muito o trabalho do segundo ano do ano que vem, para esta turma nova. Então eles não só conseguiram dar conta da alfabetização, mas da própria socialização entre os alunos, do compartilhar do material coletivo ou outras questões procedimentais que ajudam muito neste primeiro ano do fundamental, porque tinha criança que mal se encontrava com os cadernos, com o estojo, com este material mais individual, porque na sala do infantil a gente trabalha muito mais com o material coletivo e a gente acabou implementando neste começo o material individual, então houve um outro período de adaptação co este material, com o uso do caderno que eu acho que é fundamental, adequação a esta rotina diferenciada de mais escrita do tempo em que fica dentro da escola. Então se pegarmos os gráficos desde que a criança entrou no início do ano na escola e hoje a diferença é gritanta. Tinha criança que não sabia nem traçar letra e hoje estão aí caminhando. Então assim, o aprendizado foi excelente, o 
resultado é muito bom, mas... e vai depender também da criança, tem criança que é muito estimulada, tem criança com seis anos que já tem a relação com a maturidade, tem criança aí com seis anos para completar sete que está lendo e escrevendo, assim como tem crianças com a mesma faixa etária que está em outro momento. Eu acho que depende de criança para criança, por isso a gente faz uma avaliação do grupo, sim, e acaba fazendo uma avaliação individual. Para poder ver o que foi bom no trabalho e o que não foi bom. Então eu acredito que o aprendizado ocorreu de uma forma lúdica, tranqüila e as crianças deram conta do recado. Tem muitos alfabéticos, lendo e escrevendo e se eles chegassem assim no antigo fundamental de oito anos, nossa. A criançada ia deslanchar. Mas, eu acho que tem muito assim, quando o professor é alfabetizador ele vai ter este olhar sempre, não vai ter como tirar isso dele, mesmo sabendo que não se tem esta obrigação neste primeiro ano, então isso influencia e muito no resultado. E como a gente vem aí com uma experiência de uns 7 a 8 anos isso dá uma outra cara. É diferente de um professor, vamos supor que é de uma quarta série e tem que pegar esta turma do ensino fundamental de nove anos. É diferente, porque ele tem uma outra experiência. Então eu creio assim a experiência que temos de anos anteriores facilitou bastante o trabalho. Então, o resultado final, no meu ver é excelente.

Lara- E da secretaria de educação não veio nenhum objetivo que vocês teriam que ter acerca do primeiro ano?

Professora - O que nós recebemos é o seguinte: As crianças estão aí, entre aspas não precisa alfabetizar no primeiro ano do ensino fundamental, porque haverá três anos para isso e vamos trabalhando.

Lara - Essa informação veio por escrito, alguém veio aqui para dizer?

Professora - Não, não tivemos nenhum acesso a nenhum material, a diretora pediu para nós elaborarmos a partir daquilo que nós já vínhamos trabalhando.

Lara - E a diretora que deu esta orientação de que não se deve alfabetizar no primeiro ano?

Professora - Não, do ciclo inicial quando a gente pega a proposta para ler, lá já está dizendo que fica claro para nós que as crianças têm três anos para alfabetização então não precisa pegar nenhum papel para ler. Mas, vem os gráficos para gente preencher.

Lara - E estes gráficos vão para...

Professora - Vão para o departamento, cuja sigla é A.N.A.. É o A.N.A., que a gente fala preencheu o ANA, que é a tabela das aprendizagens. Eu creio assim, devia ter sido feito, esta é a minha opinião, vai implantar? Vai. Escolas vão receber estas salas, então vamos fazer um trabalho de formação, vamos orientar, temos que trabalhar currículo tal, currículo tal, ao meu ver, foi implantado e cada escola segue seu ritmo. Segue esta realidade, porque é diferente, 
uma realidade que é a do Battistini e uma realidade centro. É diferente. Então cada uma se adequou em relação ao que já tinha e aí a gente foi caminhando de acordo com o que a experiência foi nos ajudando.

Lara - Como você realiza a avaliação da aprendizagem dos alunos?

Professora - É pela ficha de rendimentos, nós temos os objetivos traçados dentro dos conteúdos.

Lara - Que vocês traçaram?

Professora - Que nós traçamos para fazer o PP deste primeiro ano do ensino fundamental de nove anos e de lá tiramos os objetivos específicos do bimestre. Daí tem os quatro bimestres e a ficha de rendimentos satisfatório ou insatisfatório.

Lara - Os professores dos primeiros anos realizam um trabalho coletivo? Por quê? Como esse trabalho é realizado?

Professora - Sim, mesmo fazendo o HTPC em horário diferente, a gente consegue fazer as trocas porque a outra professora da manhã tem contato com as professoras da tarde no horário do HTPC. Eu sou a única que faço HTPC no sábado, mas isso não dificulta o trabalho porque eu tenho esta pessoa que faz este elo. Então não teve problema neste sentido e a gente acaba sempre discutindo sobre o que a gente vai trabalhar, sobre o que discutimos no início do ano que está no PP, a gente vai destrinchando e a gente tinha colega da tarde que nunca tinha feito este trabalho então ela conseguiu se organizar, se adaptou e atender as crianças e elas estão aí também escrevendo, então a gente sempre faz este trabalho coletivo neste sentido de conteúdos, planejamentos e projetos, a gente acaba conseguindo trabalhar em parceria.

Lara - Quais dificuldades você tem encontrado na realização do trabalho com as crianças do primeiro ano do ensino fundamental? Por quê?

Professora - Falta de..nessa co..porque eu estou frisando a questão desta comunidade. Porque eu creio que o pai, a família em si precisa estar mais presente. É uma dificuldade muito grande, porque a escola tem que ensinar sim, mas as crianças precisam ter uma base, eu penso que a educação não é só a escola que tem que dar. Então, a gente fica com muita coisa para a escola, a gente acaba sendo mãe, professora, médica, psicóloga, outros atributos que a gente poderia ter das famílias que aqui nós não temos, não temos e isso dificulta o trabalho, em relação a você poder contar mais com a ajuda da família e as famílias não colaboram em tudo e em relação às atividades e tudo mais a gente ainda vive na era do mimeografo. Isso também dificulta o trabalho, graças á Deus a gente tem uma mãe que xeroca as atividades para nós, não que os mimeógrafos não tenham qualidade, eu digo assim que o dispensar tempo com este trabalho com folhas enquanto você poderia em seu planejamento, na hora do 
planejamento do seu HTPC estar pensando em outras coisas, você tem que ficar lá usando o mimeógrafo, então graças à Deus a gente tem uma mãe, que a gente fornece as folhas para ela e ela xeroca as atividades e isso facilitou bastante. Porque, querendo ou não a gente quer um trabalho de qualidade, então a gente se vira. Esta é que é a realidade. O professor acaba adequando material, acaba buscando fora, o que a gente não consegue aqui, então assim, a gente consegue realizar porque a gente corre atrás do que a gente acha necessário para que as crianças tenham acesso. Poderia ser melhor, é claro que poderia ser melhor, mas não depende só da gente.

Lara - Há formação continuada para os professores do primeiro ano do ensino fundamental? Como é realizada? Você tem acesso? Participa? Qual a sua opinião sobre estas formações? Elas ajudam você? Como?

Professora - Não, não há, não houve. Não sei se eles estão pensando em ampliar, ou nem ampliar porque não houve.

Lara - Não veio nenhuma oferta de curso da secretaria.

Professora - Não

Lara - Porque analisando o livro do HTPC de vocês havia menção a um curso à distância oferecido pela Santilhana, sabe?

Professora - Não, eu desconheço. Não me recordo, mas eu desconheço ter tido informações em relação a isso. Não me lembro de ter discutido isso e neste ano a gente não teve.

Lara - Como você tomou conhecimento da legislação que implantou o ensino fundamental de nove anos? Você participou de alguma discussão sobre esse tema? Onde? Quando?

Professora - Então, no ano passado eu lembro que nas últimas reuniões HTPC foi trazido algum material e a gente discutiu alguma coisa em HTPC assim, a questão da implantação sobre como seria é que vai implantar e ponto, daí você vê que é

Lara - Mas, você ficou sabendo da lei no ano passado?

Professora - Eu só me lembro quando a gente foi inserida neste projeto e aí a gente abarcou e saiu correndo atrás sobre o que estava acontecendo.

Lara - Então você não participou de nenhuma discussão fora da escola, só na escola?

Professora - Que eu me recordo, não. Só na escola no final do ano quando a diretora recebeu a notícia que nós teríamos aqui, quando a gente começou a falar sobre isso, mas assim falaram que vai implantar e que ela gostaria que nós ficássemos com a turma.

Lara - Como a proposta de ensino fundamental de nove anos foi discutida em sua escola? Você participou? 
Professora - Então como eu estou te falando. Como um todo não houve, que eu tenha participado, não houve, uma discussão com o grupo todo de que a gente ia implantar de como ia ser. Vai ter a gente sentou, planejou, fez PP.

Lara - Com as professora do primeiro ano e a direção?

Professora - Isso.

Lara - Pais também não participaram?

Professora - Não, que eu me recordo e que eu tenha participado, não. Não sei se em outras instâncias e outros espaços discutiram. A diretora pode ter informado, que a escola receberia, que iria alterar, inclusive o número de salas, mas a discussão não me recordo. Se teve eu não participei.

Então foi isso, para discutir a implementação foram os professores e a direção da escola?

Isso. Do departamento veio nenhuma... Não tivemos reunião nenhuma com ninguém do departamento. Nós professoras. A diretora pode até ter tido, mas nós professoras não tivemos. Lara - Então você nem foi consultada antes da lei?

Professora - Não, não lembro.

Lara - Não lembra de ser consultada em nenhuma reunião sobre se concordaria?

Professora - Não, não lembro.

Lara - Foi só com as professoras do primeiro ano?

Professora - Sim. A diretora pode ter informado, mas sentado e discutido, não.

Lara - Então você nem foi consultada antes da lei?

Professora - Não. Não lembro

Lara - E, atualmente, em quais momentos são discutidas as questões relativas ao ensino fundamental de nove anos? Nas reuniões pedagógicas ou HTPC's são discutidos assuntos referentes ao ensino fundamental de nove anos? Somente os professores dos $1^{\circ}$ anos discutem sobre isso ou os demais professores também participam e opinam?

Professora - Então você fala da implantação ou do planejamento trabalho que é realizado?

Lara - No geral?

Professora - Então, a gente faz mais na reunião de conselho de classe que é bimestral, que a gente acaba fazendo por ano/série e ano/ciclo e a gente acaba discutindo, trazendo o que acontece para outras professoras porque neste momento as professoras do fundamental de 8 anos estão presentes, então a gente acaba conversando um pouco sobre a relação da rotina, aprendizado das crianças nos conselhos. E como o HTPC eu faço sozinha, as outras professoras fazem em outro momento.

Lara - No HTPC no sábado que é o que você faz, não foi discutido o tema? 
Professora - Não.

Lara - $\mathrm{O}$ ensino fundamental de nove anos foi discutido com as crianças? Você conversou com elas sobre isso? Existem espaços de participação para elas dentro da escola? As crianças foram consultadas sobre o ensino fundamental de nove anos e suas novas rotinas? Como são estas rotinas? Você fez algum "combinado" com elas? Quais foram?

Professora - Que eu me recordo, não. Teve com os pais, tanto que eu estava de licença gestante, mesmo assim eu vim e conversei com eles informando que eles não eram mais do infantil, mas do fundamental que mudou a nomenclatura, tanto que os pais tomaram ciência desta mudança na reunião inicial do começo do ano. Quando a gente se apresenta e fala um pouco do trabalho, mas com os alunos é no decorrer no início a gente falou um pouquinho que eles não estavam mais de seis anos que agora era outra nomenclatura, mas de uma maneira que faz com que ele entenda que agora eles estão numa turma de ensino fundamental e que eles não eram uma turma do infantil. É porque com criança não se entra em muitos detalhes, o que eles querem é vir para a escola e participar das atividades a discussão em si a gente não vai discutir com as crianças, não é?

Lara - Existe um espaço de participação das crianças dentro da escola?

Professora - Como assim.

Lara - Um espaço onde elas possam discutir algum problema, a não estou gostando disso?

Professora - Não. A diretora tinha um projeto onde as crianças pudessem participar das reuniões do conselho, ma seu não sei se isto ocorreu porque eu não faço parte nem do conselho nem da APM e ela costuma fazer as reuniões juntas, mas eu não sei se isso foi implementado.

Lara - E da rotina, você fez algum combinado com as crianças de como seria?

Professora - Então, o que nós combinamos com eles, em relação... porque como a gente estava começando com atividades diferenciadas de culinária, de arte e tudo mais estes combinados até do uso dos espaços, não é, de como a gente iria usar isso durante a semana que nós teríamos a brinquedoteca, mas ia depender do aprendizado que tivéssemos em sala de aula, então no sentido da organização da rotina isso sim foi discutido com as crianças. Eles vão anotando no caderno, na medida em que eles vão realizando as atividades eles vão anotando no caderno, da rotina que a gente vai fazer mas colocando eles a par do que vai acontecer no dia então no decorrer da semana eles já sabem o que vai acontecer.

Lara - Mais algum comentário geral?

Professora - A gente fica preocupada é que às vezes achamos que poderíamos ter feito melhor, se tivesse tido um acesso a materiais, até um apoio maior do departamento, mesmo 
sem saber se eles têm pernas para fazer esse apoio em todas as escolas, mas a gente faz o que a experiência vem nos mostrando e que tem dado certo. $O$ trabalho é realizado pensando nisso, receber as crianças para o segundo ano do fundamental mais preparadas, vamos dizer assim. anos diz que temos que fazer e isso tem dado certo, neste sentido pensamos que se isso tivesse ocorrido as crianças chegariam melhor preparadas no segundo ano. Por ter experiência anterior com o primeiro ano do ensino fundamental isso nos ajudou a pensar isso que as crianças poderiam chegar melhores no segundo ano, pelo menos enquanto conteúdo para que lá ele pudesse deslanchar mais e isso mostra que eles aprendem, mas que eles precisam ser estimulados. Isso provou para nós que aqui no fundamental a gente conseguiu fazer, mas lá no infantil será que tinha sido feito? A nossa experiência anterior diz que não. Porque muitas crianças inclusive chegavam para nós sem saber o nome, sem saber o alfabeto, sem saber aquilo que achávamos que podia ter sido feito e que não aconteceu. Não é nem uma crítica ao Infantil, mas a escola poderia ter outro projeto que não fosse este, mas como nós estávamos aqui recebendo estas crianças e hoje a gente trabalha com elas, a gente sabe que o quanto antes este trabalho é possível na educação infantil. Até acho que alteração do tempo da criança na escola, facilitou. Porque lá eles teriam só quatro horas e no fundamental são cinco, então aproveitamos esta hora mais para puxar mesmo, para leitura, para escrita...

Lara - E para o ano que vem para continuidade para o $2^{\circ}$ ano, $2^{a}$ série vocês já estão começando a conversar?

Professora - Não, ainda nada foi feito, haverá um pré-conselho na semana que vem, a gente está pensando em fazer em nossos HTPCs, mas não foi feita nenhuma discussão neste sentido destas alterações. A nossa intenção é deixar os portfólios organizados, porque temos a intenção de mostrar a maneira como elas chegaram.

Lara - Vocês têm um portfólio da sala ou individual?

Professora - De cada criança. Cada criança tem o seu e ali você consegue nitidamente ver a evolução de cada criança. E a orientação é que esta criança tenha este portfólio durante toda sua caminhada escolar.

\section{Entrevista com a professora 2}

Lara - Qual é a sua formação? 
Professora - Fiz magistério e sou formada em Educação Artística com habilitação em Artes. Lara - Há quanto tempo você trabalha no magistério?

Professora - No magistério trabalho há 23 anos, sou efetiva e na rede de São Bernardo do Campo estou contratada como professora conveniada (convênio entre a prefeitura e o Estado por conta da municipalização).

Lara -E, você já trabalhou com a primeira série?

Professora - Sim, na rede de São Bernardo do Campo trabalho com o $1^{\circ}$ ano do ciclo I já há oito anos, também tenho experiência com a educação infantil em rede particular e pública.

Lara - E, você que escolheu trabalhar com o primeiro ano neste ano?

Professora - Escolhi porque sou apaixonada por alfabetização, é um trabalho que exige muita dedicação, reflexão e parceira entre as colegas e alunos, mas no final o resultado é gratificante.

Lara - E, quais as expectativas que vocês tinham diante deste trabalho com o primeiro ano?

Professora - Na verdade eu acho que a nova organização de ensino gerou uma certa ansiedade com relação ao currículo, rotina dos alunos, formação para os professores e a expectativa é que o resultado seja o mais satisfatório possível para os alunos.

Lara - E o que você acha do Ensino fundamental de nove anos? Você acha que ele contribuiu para a democratização do ensino?

Professora - $\mathrm{O}$ ensino fundamental de nove anos é algo novo, em nossa rede a implantação está iniciando este ano e eu acredito que ainda é cedo para uma opinião a respeito.

Lara - Na sua opinião, porque você acha que o governo ampliou?

Professora - Para garantir o acesso das crianças na escola.

Lara - E qual foi a reação das crianças ao chegarem nesta escola?

Professora - Foi tranquilo, muitas já frequentavam a escola na Educação Infantil e conheciam bem o espaço e os pais já haviam conversado sobre a mudança no horário de aula.

Lara - E quais foram as orientações que você recebeu para trabalhar com as crianças de seis anos? Veio algum material didático, um documento de orientação.

Professora - Não recebemos nenhum material, organizamos nosso planejamento semanalmente de acordo com o projeto político pedagógico da nossa unidade escolar.

Lara - E, que mudanças mais foram realizadas na escola?

Professora - Não foram realizadas mudanças, pois a escola já atende Educação Infantil.

Lara - Houve mudança no espaço físico da escola para receber as crianças de seis anos? Quais? 
Professora - O que houve foi adequação do mobiliário (mesas e cadeiras para os alunos) e a criação de uma brinquedoteca.

Lara - E, você acha que estas mudanças atendem as necessidades das crianças?

Professora - Sim.

Lara - O trabalho com as crianças de seis anos está articulado ao planejamento dos demais anos do primeiro ciclo do ensino fundamental?

Professora - Mais próximo das $1^{\mathrm{a}} \mathrm{s}$ séries.

Lara - O que é trabalhado no primeiro ano? As crianças estão sendo alfabetizadas? Como é realizada a alfabetização da criança de seis anos?

Professora - Trabalhamos as diversas áreas de conhecimento, socialização, autonomia e a importância do brincar. As atividades acabam sendo direcionadas para a alfabetização que ocorre de maneira lúdica através de jogos e brincadeiras.

Lara - Você acha que as necessidades das crianças de seis anos são melhores atendidas na escola de ensino fundamental ou na escola de educação infantil? Por quê?

Professora - Acho que tudo depende da estrutura da escola, da organização dos espaços e da rotina planejada pelos professores.

Lara - Como é a rotina das crianças do $1^{\circ}$ ano? Há brincadeiras? Quais? Com que freqüência? Em quais espaços da escola as crianças realizam estas brincadeiras? Em sala de aula, elas brincam? Elas trazem brinquedos de casa? Como isso funciona dentro da sala de aula?

Professora - A rotina é bem diversificada. As brincadeiras ocorrem sim, normalmente realizamos um resgate das brincadeiras conhecidas pela turma e introduzimos algumas novas. Os espaços mais utilizados são o pátio externo e interno, quadra esportiva e a brinquedoteca onde eles tem um horário de trinta minutos por dia para utilizarem este espaço.

Os alunos costumam trazer brinquedos de casa na $6^{\mathrm{a}}$ feira e reservamos um horário de mais ou menos 40 minutos para brincarem, esta atividade muitas vezes ocorre junto com outra turma do $1^{\circ}$ ano no espaço do pátio.

Lara - Que mudanças você observa em seus alunos do começo do ano para cá? E no que se refere à aprendizagem, os alunos estão acompanhando as aulas? Eles estão correspondendo aos objetivos propostos e as suas expectativas? Quais são os objetivos do primeiro ano? Houve alguma orientação dos órgãos centrais sobre os objetivos do primeiro ano?

Professora - Observo mudanças no comportamento quanto a autonomia, oralidade, também avançaram muito na aprendizagem (escrita e leitura). 
Os objetivos estão voltados para a oralidade, leitura, escrita, valorização da cultura da infância, momentos de brincadeiras. Na matemática procuramos contemplar os eixos: números e operações, espaço e forma, grandezas e medidas e tratamento da informação.

Não recebemos orientações dos órgãos centrais com relação aos objetivos o que a Escola recebeu foi uma espécie de livreto informando sobre algumas orientações para a implementação do ensino fundamental de nove anos.

Lara - Como você realiza a avaliação da aprendizagem dos alunos?

Professora - Realizo a avaliação de forma contínua, observando e registrando os avanços e as dificuldades encontradas pelos alunos para poder organizar ou reorganizar meu planejamento. Lara - Os professores dos primeiros anos realizam um trabalho coletivo? Por quê? Como esse trabalho é realizado?

Professora - Sim, nos reunimos nos HTPC onde planejamos juntas, elaboramos os projetos e compartilhamos nossa prática.

Lara - Quais dificuldades você tem encontrado na realização do trabalho com as crianças do primeiro ano do ensino fundamental? Por quê?

Professora - A maior dificuldade é a pouca participação por parte da família dos alunos.

Lara - Há formação continuada para os professores do primeiro ano do ensino fundamental?

Como é realizada? Você tem acesso? Participa? Qual a sua opinião sobre estas formações? Elas ajudam você? Como?

Professora - Temos formação, mas não específica para os primeiros anos. As formações são para todos os professores e sobre as diversas áreas do conhecimento.

Lara - Como você tomou conhecimento da legislação que implantou o ensino fundamental de nove anos? Você participou de alguma discussão sobre esse tema? Onde? Quando?

Professora - Tomei conhecimento pelos meios de comunicação, pela rede de ensino e na unidade escolar.

Lara - Como a proposta de ensino fundamental de nove anos foi discutida em sua escola? Você participou? Você foi consultada sobre o ensino fundamental de nove anos? Por quem? Quando? Sua opinião foi levada em conta na implementação da proposta?

Professora - Ela não foi discutida, tomamos conhecimento da implementação nos HTPCs. Não fui consultada.

Lara- Quais segmentos da comunidade escolar foram chamados a discutir a implementação do ensino fundamental de nove anos?

Professora - Trio gestor. 
Lara - A implementação do ensino fundamental de nove anos foi discutido no Conselho de Escola?

Professora - Os pais da educação infantil foram reunidos pela direção da escola onde tomaram conhecimento da implementação do ensino fundamental de nove anos.

Lara - Em quais momentos são discutidas as questões relativas ao ensino fundamental de nove anos? Nas reuniões pedagógicas ou HTPCs são discutidos assuntos referentes ao ensino fundamental de nove anos? Somente os professores dos $1^{\circ}$ anos discutem sobre isso ou os demais professores também participam e opinam?

Professora - Nos HTPCs discutimos a respeito no início do ano. Todos os professores foram convidados a participar da elaboração dos objetivos para trabalharmos com este ano, mas no final quem acabou elaborando os objetivos fomos nós professoras do $1^{\circ}$ ano com o auxílio e orientação do trio gestor.

Lara - O ensino fundamental de nove anos foi discutido com as crianças? Você conversou com elas sobre isso? Existem espaços de participação para elas dentro da escola? As crianças foram consultadas sobre o ensino fundamental de nove anos e suas novas rotinas? Como são estas rotinas? Você fez algum "combinado" com elas? Quais foram?

Professora - Não foi discutido, na verdade elas foram informadas. A rotina segue uma grade curricular e também fazemos uso dos espaços: biblioteca interativa (uma vez por semana); laboratório de informática (uma vez por semana); ateliê de artes (uma vez por semana); brinquedoteca (todos os dias por 30 minutos); quadra esportiva (duas vezes por semana). Os combinados realizados com os alunos no momento da roda de conversa foram com relação ao uso adequado dos espaços, equipamentos e normas de convivência.

\section{Entrevista com a professora 3}

Lara - O que você acha do ensino fundamental de nove anos? Você acha que ele contribui com a democratização de ensino?

Professora- Eu acho que é um processo. Não acho que tenho que concordar ou discordar, a gente está nesta mudança desde o ano passado. Os pontos negativos ou positivos veremos com o tempo.

Lara - Até agora que pontos positivos e negativos você viu?

Professora - Eu não consigo enxergar ainda. Mas eu achei que vem mais imaturas, então a professora tem que estar preparada com esta fase, que já não era uma preocupação da professora de $1^{\text {a }}$ série porque eles eram diferentes. Agora eles vem menores, temos que ter 
outro foco, uma preocupação maior com a maturidade deles também. A gente precisa estar preparadas para estes alunos, não é simplesmente trocou vamos mudar. Primeira série agora é fundamental de nove anos e a gente fazer o que bem entender, então temos que ter um respaldo, precisamos estar bem preparadas mas temos que ter alguém articulando isso, porque como é que o professor fará isso, quais são os objetivos a serem trabalhados com estes alunos da primeira série, inclusive no laboratório eu não tive respaldo nenhum para isso. Acabou acontecendo o que eu acho, é conversando com o professor porque o meu respaldo é o professor. É o planejamento dele, se ele estiver perdido eu também vou ficar perdida. Por isso é muito importante este momento de sentar com o professor e planejar, ver o que ele está fazendo para eu tentar articular este trabalho com o trabalho aqui do laboratório de informática.

Lara - Em sua opinião porque você acha que o governo ampliou o ensino fundamental para nove anos?

Professora - Não parei para pensar nesta questão.

Lara - Você acha que é por causa do direito á educação, por causa da verba do FUNDEB, porque internacionalmente tinha mais e tinha aumentado?

Professora - Acho que tem várias questões políticas sempre tem alguma coisa por trás. Quanto a minha opinião eu mesma não parei para pensar, mas alguma questão política, com certeza, nisso tem. Não é só porque é o melhor para as crianças, tem questões ideológicas por trás.

Lara - E qual foi a reação das crianças ao chegarem na escola no início do ano?

Professora - Como estou no laboratório é diferente para eu falar, mesmo porque eles demoram um pouco para usarem o laboratório. As aulas começam em fevereiro e eles começam a vir aqui depois de umas duas semanas.

Lara - Com todos os anos é assim ou só os primeiros anos?

Professora - Não, todos os anos. Porque até a gente conseguir um momento para conseguir planejar com os professores, a gente definir o que vai fazer naquela primeira semana e a partir daí o que vai continuar. Então eles passam por uma adaptação, mas eu percebo que no laboratório depois que eles entram que é uma atendimento para o infantil.

Lara - O infantil não participa da informática?

Professora - Agora, não mais, por falta de horário, temos mais salas e priorizamos os do fundamental, por conta das aulas de robótica para os $4^{\circ} \mathrm{s}$ anos que tem uma aula a mais por semana.

Lara - E você recebeu alguma orientação específica de como trabalhar com estas crianças? 
Professora - Não. Meu respaldo são as nossas reuniões, o que a diretora passa para nós. Que foi uma novidade para todo mundo no ano passado e continua sendo neste ano. A minha troca com a equipe gestora e com os professores é o que tem me orientado.

Lara - Você participa de reuniões na secretaria de educação?

Professora - Sobre informática sim, onde discutimos sobre mudança, atendimento apenas do fundamental, mais sobre a estrutura, a organização, mas como trabalhar, não.

Lara - E como você trabalhava com as crianças do infantil?

Professora - Eu trabalhei de acordo com o planejamento de cada professor, trabalhando com a identidade da criança, tinha professora fazendo a agenda dos amigos e informatizamos, fizemos uma agenda eletrônica com nome da criança, brincadeira preferida, número de telefone. Pesquisamos o site do Romero Brito, relações com a pintura, a capa da agenda foi de acordo com as obras do Romero Brito. Atividades da sala de aula passaram para os projetos da sala de aula, articulando as novas tecnologias às atividades de sala de aula.

Lara - De acordo com a sua experiência o trabalho com as crianças de seis anos está mais articulado com o ensino fundamental ou com a Educação Infantil?

Professora - Eu acho que está entre os dois. Como é o segundo ano, não temos ainda os objetivos claros. Está no meio.

Lara - Você acha que elas são melhores atendidas no fundamental ou na Educação Infantil?

Professora - Não sei te falar. Como estou na informática, não tenho como balizar. Acho que quem poderia te responder isso é a coordenadora ou a professora que acompanha a turma, mas eu tenho pouco tempo com as crianças. Diferença tem, mas quais são elas eu não sei. O que posso constatar é que eles estão mais imaturos para atividades de alfabetização. Por exemplo, com as crianças do fundamental de oito anos, atividades com o nome eu já conseguia na terceira semana de aula, ou seja, na terceira aula de informática, agora não. Porque eles já vêm com outras dificuldades.

Lara - Como você ficou sabendo da ampliação do ensino fundamental para nove anos?

Professora - Na escola, nas reuniões a partir de 2008 e 2009.

Lara - Tem algum outro espaço onde você tenha participado da discussão sobre o ensino fundamental de nove anos?

Professora - Não. A gente vê entrevistas na TV, jornal.

Lara - E aqui na escola em quais momentos este assunto foi discutido?

Professora - HTPCs, reuniões pedagógicas, acho que em todo momento que foi necessário foi aberta a discussão.

Lara - Você foi consultada sobre o ensino fundamental de nove anos? 
Professora - Não.

Lara - Que segmentos da comunidade escolar você sabe que participaram da discussão?

Professora - No Conselho de Escola.

Lara - Com as crianças foi discutido?

Professora - Não.

\section{Entrevista com a diretora}

Lara - Conte-me um pouco da sua experiência profissional.

Diretora - Eu fiz magistério, depois que eu tinha minhas filhas adolescentes, entrei no magistério estava com 30 anos, por acaso. Terminei o magistério e por acaso, vamos fazer Pedagogia? Fui fazer Pedagogia e, por acaso eu peguei duas salas de aula do Estado. Teve um concurso público, eu me formei em 89 e em 90 teve esse concurso do Estado e entrei com a primeira e a quarta do Estado. Trabalhei com a primeira série de alfabetização. Em 94 prestei concurso na prefeitura para educação infantil em São Bernardo. Em 94 entrei na prefeitura e pedi afastamento do Estado e em 2006 eu exonerei do Estado e fiquei só na prefeitura. Eu já tinha prestado dois concursos e aqui já tinha duas matrículas na época e agora querem tirar. Em 1999, surgiu na rede a história da PAPE que é: Professor de Apoio Pedagógico. Eu fui ser PAPE e nesta função você estuda muito, na época tinha bastante formação. Quando eu entrei, a rede não tinha ainda o ensino fundamental, tinha o infantil, não tinha da primeira série a quinta. Eu tive ótimas formações daquela época. No período que eu fui fazer pós, fazer complementação. Primeiro em supervisão escolar, minha formação era de pedagogia, depois fui fazer psicopedagogia porque eu me interessava. Até hoje eu acho fascinante a área de educação. Depois, em 2001 prestei concurso para direção fui lá e fiz todos os exames médicos e não quis assumir, cheguei lá e vi que não era isso que eu quero nesse momento para minha vida. Por obra do destino, naquele ano que eu não quis ser diretora, fui ser PAPE que hoje é coordenadora de uma escola que estava inaugurando o ensino fundamental, tinha 44 salas por período lá eram 22 só de ensino fundamental. Eu conhecia muito, tinha bastante formação do infantil. No fundamental entra conselho, ficha de rendimento e fui em 2003 e aprendi muito porque tive que aprender na raça, eu não sabia e sempre com aqueles mais experientes, e a diretora na época era muito competente e eu ali de bico. Acho que aprendi muito com ela e com o desafio, pois era uma escola grande. No final de 2005, mais ou menos dezembro, janeiro de 2006, abriu outro concurso para direção. Minha amiga falou: -"Vamos prestar?" De repente eu passo e vou ter o maior problema. Fiz o concurso e passei, aí não tinha mais 
jeito agora assumo. Fui logo chamada, peguei uma escola grande, eu tinha noção de direção, mas foi em 2006, 2007 peguei minha titularidade. Porque quando você entra, você é titular do cargo e eu peguei aqui no Isidoro. Estou aqui vai fazer 4 anos e não quis sair daqui de remoção porque a gente está em um processo, para uma coisa ter resultado você tem que ficar, não tenho medo de mudanças mas eu acho que você tem que ver que aquilo funcionou e não parar pelo meio do caminho. Enfim, acho que sobre a questão profissional eu estou na direção há 4 anos e agora estou fazendo pós- graduação em gestão que foi oferecido para todos os diretores da rede. Para quem quisesse... ninguém me obrigou a fazer. É interessante. Eu tenho algumas expectativas: o curso começou agora, no começo de novembro e, é de um ano e meio de curso. É bom porque tem coisas nesta gestão que você ouve e você tem o conhecimento prévio do que é, só que no curso você vai ampliar este conhecimento. Então dói um pouquinho no começo. Eu vou ter que ler muito. A expectativa é assim: como você vai ser gestora de uma escola? Como você vai melhorar? Quando você começa a refletir, mais você é um diretor, tem conhecimento que era isso e aquilo você consegue melhor gerir até o próprio dinheiro da APM.

Lara - Você acha que seu trabalho com a Educação Infantil contribuiu de alguma forma com o trabalho que você realiza agora como diretora?

Diretora - Sim, com certeza. Nível de ensino para mim tanto faz, acho que é tudo você tem que tratar como o mesmo é aluno, não é? Você aprende ali com eles. O infantil é uma delícia trabalhar. É uma pena que às vezes se perde. Você vê a quantidade de brinquedo que eu comprei para escola com verba da APM. Isso vem muito do infantil, como fui professora, fui PAPE do infantil o imaginário é muito presente e não se perde. Eu, por exemplo, adoro boneca. Antes quando o fundamental foi municipalizado ele vinha com uma característica de carteiras, de que o brincar fica lá fora. Isso eu estou te falando da minha experiência. Você não tinha o dia do brinquedo, não tinha as atividades diversificadas no fundamental, porque era aula. Quer dizer, você trabalhar com brinquedo no fundamental, quem disse que não é aula? Porque a aula necessariamente tem de ser: ficar sentado, aquela aula expositiva chata. Tanto é que estávamos discutindo na reunião pedagógica de sexta-feira que, nós temos a brinquedoteca, só que ela é mais voltada para as crianças da educação infantil do primeiro ano de nove e oito anos. Porque, os grandes, eu digo os grandes em tamanho, ali não tem brinquedos adequados para eles. Eles levam os jogos para a sala de aula e as professoras estavam reclamando que eles quebram, mas eu disse para elas que tem que ter uma intervenção, você tem que ter um propósito para dar o jogo do detetive, por exemplo. Se você vai fazer um jogo de matemática você não vai só jogar, tem o pedagógico. Isso daí vem do 
infantil. Então a gente vai montar uma sala de jogos. Ano que vem vou ter uma sala ociosa. São tantas demandas e entre elas é deixar uma sala e se um professor quer dar uma aula de matemática e quer trabalhar com jogos ele poderá, não ir lá no oba, oba, no laissez - faire mas, trabalhar matemática com jogos para que você centralize o espaço e que você vá com um propósito de desenvolvimento, não é? Tem tantos jogos aqui, tanta coisa bacana que é para trabalhar o pedagógico, não só para brincar propriamente dito. $\mathrm{Na}$ verdade o brincar o professor observa a brincadeira porque tem que ter o parceiro ali. Pelo menos essa é a minha visão que vem do infantil.

Lara - Como você ficou sabendo da ampliação do ensino fundamental de nove anos?

Diretora - A lei. A rede tem que se adequar em dez anos e São Bernardo não tinha se adequado ainda. O último ano era este. Eu fiz parte da comissão. Eles elaboraram uma comissão para que a gente, para que fosse implantado na rede, o fundamental de nove anos. Foi uma loucura, tinha data de corte. O Estado de São Paulo tinha outra data diferente daqui. Ano passado começaram com a data de corte, março fazia aniversário e agora parece que mudou. Foi tranquila a passagem, tive que fazer reunião com os pais. Nós temos aqui as salas do infantil cinco, nós tínhamos seis salas do passado para esse, dentro da sala eu tinha crianças que fazia seis anos em março e outras que faziam em primeiro de abril. Tive que dividir, chamar os pais e explicar a resolução para os pais e explicar que na escola havia dois modelos de primeiro ano, de oito e fundamental de nove anos. Muitos ficaram chateados porque o filho foi para o de nove e outro para o de oito. Mas não tem jeito, é lei. Não tem como você dar um jeitinho. O problema às vezes acontece quando vem transferências de outros estados porque aqui nós começamos com o fundamental de 9 este ano em 2010, só que tem estados principalmente do nordeste, em que faz tempo que eles mudaram porque tiveram dez anos para se adequar. E quando você pega, o menino está lá na $2^{\mathrm{a}}$ série do fundamental de 9 anos só que aqui equivale ao $1^{\mathrm{o}}$ ano de 8 anos e vai convencer este pai. Porque o pai quer matricular ele na segunda de oito, mas só temos segunda de 9. Então nós estamos funcionando paralelamente, vocês perceberam? Noutro dia veio uma mãe do Rio Grande do Sul e ela ficou brava e disse que iria falar com a Secretária da educação. Expliquei para ela que transferência de outro estado aqui equivale pela idade e mostrei a resolução. $\mathrm{O}$ menino está alfabetizado, e eu falei que poderia pensar par ao próximo ano fazer uma reclassificação. Mas ele não tem defasagem idade/série, mas por aprendizagem a gente pode pensar numa... (a secretária interrompe para dizer que tinha uma mãe esperando) Onde eu estava mesmo. Ah! O menino tinha idade para estar numa série de 8 anos e não numa terceira série, então ele não entra em defasagem idade/série aqui não. Eu expliquei para a mãe que ele iria terminar no 
mesmo tempo que ele terminaria lá. Porque lá ela vai ter nove anos e aqui ela vai ter oito. Então é difícil par ao pai, porque é tudo muito novo. Eu estava fazendo os conselhos por ano ciclo. E se você pegar as primeiras séries de nove e comparar com a primeira série de oito os alunos do fundamental de nove anos estão mais alfabéticos do que os do fundamental de oito anos. Daí eu fiquei pensando sobre o que mudou, porque eles estariam no infantil. E isso é um dado de pesquisa para mim porque este fundamental de nove anos está começando. Como também na reunião pedagógica nós estávamos falando de apoio pedagógico. Quando você faz um conselho de classe, você faz os encaminhamentos. Porque o conselho de classe não é para rotular o aluno, muitos professores ainda veem o conselho de classe para legitimar que ele ensinou mais que o aluno não aprendeu desta maneira ele tira a sua culpa. Ainda é muito difícil trabalhar com o conselho de classe. Conselho de classe é um encaminhamento, se o aluno não aprendeu dessa forma o que vamos fazer para que ele avance mais. Estamos falhando no apoio pedagógico. Os professores têm dificuldade em arriscar. Estamos pensando em fazer um apoio diferente, com jogos e não ficar com a criança só na sala, isso não adianta. Lara - E essa comissão que você fez parte além da nota de corte o que mais vocês discutiram? Diretora - As leis que fundamentaram bastante leitura. A pesquisa de como seria implantado em outras redes. Na época Santo André já tinha, nós pesquisamos São Paulo, foi muita discussão

Lara - Vocês elaboraram alguma coisa no final?

Diretora - Na comissão que eu fiz parte o que saiu foi a idade de corte, os encaminhamentos que deveríamos passar para os diretores. Baseados no livro do Estado "Ensino fundamental de nove anos do MEC". Nos baseamos nele esse ano e fomos organizando os objetivos para o PPP. Um pouco na educação infantil, um propósito, mas uma proposta curricular que venha da rede para cá, isso ainda não está elaborado.

Lara - Você concorda com o ensino fundamental de nove anos?Por que você acha que foi bom?

Diretora - Sim. Na verdade eles estão legitimando uma coisa que já acontecia. Crianças já vinham para a educação infantil com essa faixa etária e já era trabalhada... Você sabe que a alfabetização é um processo, desde que você nasce já está se alfabetizando e também daí diminui o número de retenção. Eu não tenho muito caso de retenção aqui na escola, eu acredito no processo, não adianta você reter. Se você vai reter uma criança você vai ter que saber o que oferecer para ela ano que seguinte. $O$ fundamental de nove anos, os três primeiros anos é o primeiro ciclo, antes tinha três anos para serem alfabetizados. Foi melhor para o 
aluno. Eu acho que o ensino obrigatório ainda é de nove anos, porque o ensino médio não é obrigatório.

Lara - tem uma lei agora que vai ser dos 4 aos 17.

Diretora - Sim , mas quando ela tem que ser de verdade aplicada...

Lara - Tem o ano, eu acho que é até 2014 ou 2016.

Diretora - Mas, assim obriga. O pai não é obrigado a colocar o filho na educação infantil de cinco anos, quanto a obrigação os pais não tem esta noção ainda. As crianças faltam e a escola precisa ir atrás.

Lara - Então você também concorda com o ingresso das crianças de seis anos no fundamental?

Diretora - Sim. Eu concordo sim porque é uma oportunidade. Desde que respeite essa especificidade do aluno. Você não vai pegar um menino de cinco, seis anos e colocá-lo numa carteira, como era no meu tempo, aquela carteira cheirando à lustra-móveis impecável sentado. Você acabava aprendendo pelo medo. Agora você tem que construir essa aprendizagem, essa interação. É mudança para melhor. Não é deixar ele apenas sentado na carteira e dizer: - Brincar não é aqui é na rua, é em casa. Por que não na escola?

Lara - Além desse critério didático para formar primeiro ano e primeira série teve algum outro critério para formar duas turmas pela manhã e duas à tarde de primeiro ano?

Diretora - Não, o critério é o básico mesmo, você tem que equilibrar as turmas.

Lara - E como os professores escolheram as turmas do primeiro ano?

Diretora - Como eu já estou a bastante tempo aqui na escola, você conhece o perfil dos professores. O perfil que eu identifico é o perfil que ele gosta. As professoras que pegaram o fundamental de nove anos foram aquelas que já estavam no primeiro de oito, mas que tinha seis de oito dividido duas e duas. Eu acho que fiz uma ótima atribuição. Fizeram um ótimo trabalho. Tanto é que como eu falei no começo tem salas do fundamental de nove que estão melhores que do fundamental de oito anos. Elas brincam muito com essas crianças e as outras não. Para você ver. Pode estar aí a chave, não é?

Lara - Que modificações foram feitas no espaço físico da escola para acolher as crianças?

Diretora - As modificações que eu consegui fazer foram: substituir as carteiras de sentar uma atrás da outra e coloquei mesinhas da educação infantil. Montei a brinquedoteca que não tinha. O espaço que eu tinha aí eu aproveitei. Ainda, como no ano que vem vamos receber crianças de quatro anos, infantil de cinco anos a gente vai ter o infantil de quatro, são 148 crianças que virão ano que vem. Estamos rebaixando pia de banheiro, colocando bebedouro 
com filtro de água mais baixo. Só o parque que eu ainda não consegui por questões de verba. Sandra - Tem um suporte no banheiro para as crianças subirem. Já tinha antes?

Diretora - Não, mas eu não gosto daquele tablado, porque acho ele perigoso. Foi apenas um improviso. Tanto é que só coloquei no banheiro. Inclusive hoje á tarde virá uma pessoa para rebaixar duas daquelas pias.

Lara - Quais são os objetivos do primeiro ano quando vocês montaram o fundamental de nove anos?Quais expectativas para essa criança?

Diretora - Tínhamos um pouco de receio, porque todos os alunos que a gente tinha do fundamental da sala de cinco anos iriam de qualquer forma para a turma de oito anos.

Lara - Eles iriam entrar com seis anos no fundamenta de oito?

Diretora - Alguns não por causa da idade de corte, outros ficariam na sala de cinco, mas a maioria que estava aqui comigo iam todos para a primeira série porque já tinha sala de cinco. Se não houvesse a nota de corte eles iriam para a primeira. Lá no Marcelo Roberto Dias que é uma escola que tem educação infantil e creche funcionava o fundamental de quatro anos. Alguns alunos de lá vieram para cá, para o fundamental de nove pela idade de corte e todos os meus ficaram divididos por causa da lei, mas os outros que nunca foram a escola vieram para cá. Fiquei com os meus e dos meus tive que dividir e deu um nó na cabeça de muitos pais porque antes trabalhávamos com ano cheio. Vamos supor: - Uma criança de cinco anos, entrava na sala de cinco anos com ano cheio, mesmo que ela fizesse cinco anos em dezembro, no ano seguinte ela ia para a sala de seis anos, ano cheio; sete anos, ano cheio. Toda a criança que iria para primeira série, ela faria sete anos até 31 de dezembro, só que quando chega ano passado com o fundamental de nove não foi mais ano cheio. Na comissão: São Paulo era junho, aqui ficou em março. Então aquelas crianças que estavam comigo que entraram no infantil com o ano cheio de repente na hora de entrar no fundamental não era mais ano cheio, teve corte. Eu fiquei com uma parte fazendo aniversário, vocês perceberam? E outras não, pois isso que fiquei com duas crianças que ficaram na turma de nove anos e na turma de oito. Lara - Para definir o currículo vocês usaram o livro do MEC?

Diretora - Livro do MEC, fundamental, infantil e fizemos muita busca. Quem já está no processo de ensino fundamental de nove anos está avaliando se foi bacana. E ano que vem vamos tentar melhorar. De modo geral foi bom, para mim e para o começo.

Lara - E como é realizada a avaliação de aprendizagem do aluno do primeiro ano de nove. Tem a ficha de rendimento?

Diretora - A ficha de rendimento é uma coisa simbólica para o fundamental de nove anos, mas tem. Nós temos aqui, a gente entrega por bimestre ou trimestre. São três avaliações por ano; 
chama-se "A ANA" Não sei se vocês viram esse impresso, vem da secretaria, tem uma data de entrega, é a pesquisa do alfabético e não alfabéticos. No decorrer desse processo. E essas crianças também entraram. Para a gente fazer essa pesquisa, envio para eles assim: um pré silábico com valor ou sem valor, mas eu não quero número, quero nomes. Trazendo isso para o fundamental de nove anos, o professor coloca os nomes e as hipóteses. Até o final do ano você tem um mapa, no conselho tem o perfil desse aluno em termos de estatística, como que ele foi, como começou, onde ele estava e onde ele está. As atividades, as conversas com os professores, a observação, relatório que elas fazem, as avaliações foram baseadas em registros, acompanhamento dos alunos. A gente trabalha bem em cima de processo.

Lara - E como foi a reação das crianças ao chegaram na escola, tinham crianças que chegaram na escola pois tinham crianças que não estavam aqui?

Diretora - Não tivemos problemas. Fui privilegiada porque a maioria estava aqui, os que não estavam, estavam pela primeira vez na escola, estavam fora da escola. Foi dentro do normal.

Lara - E além da comissão você participa de algum curso sobre o tema ou teve algum curso para os professores?

Diretora - Fiz vários encontros do fundamental, como eu estava na comissão, eu fui em vários encontros. Formação específica não houve.

Lara - Para os professores também não?

Diretora - Não

Lara - eu estava olhando nas atas do HTPC sobre um curso da editora moderna. Alguém daqui da escola participou?

Diretora - Não.

Lara - Os professores receberam material didático específico, ou elas montaram o material dela?

Diretora - Foi montado, não veio nada específico foram se adequando.

Lara - E o material que veio da prefeitura de SP como você avaliaria esse material?

Diretora - O marronzinho? Foi um norte. Foi discutido. Hoje estou com quatro professores começando do fundamental de nove anos, mas esta discussão foi se expandindo para todo mundo.

Lara - Você considera suficiente esse material que a prefeitura enviou?

Diretora - Não. Precisa de mais. Estamos em processo. Foi o primeiro ano do fundamental de nove anos aqui. Teve investimento, mas mais orientação, não teve nenhuma formação específica. 
Lara - Nem para este ano ofereceram este tipo de formação para o ensino fundamental de 9 anos?

Diretora - A formação mais básica que teve foi inclusão que tem haver com todos, teve questão de meio ambiente. Os coordenadores tiveram curso de Letra e Vida que tem haver com a alfabetização. Mas eles também começaram este ano. Mais nada de uma formação específica para o fundamental.

Lara - além do HTPC, do proposto do fundamental foi discutido com todos os professores, pais no conselho de escola teve discussão do fundamental de nove anos?

Diretora - Sim. Ele é basicamente constituído pelos pais eu apresentei legislação, mas é tudo processo. Mas passou conselho. É que na verdade o conselho faz parte da escola. E uma grande dificuldade é encontrar pais para montar APM e Conselho, por conta da participação.Inclusive é um tema que eu gostaria de pesquisar. Conselho de escola e APM. Para que ter os dois? A APM tem valor legal de receber verba e o conselho não? Por que não funde os dois. Porque na verdade os pais são os mesmos. Você não consegue montar parte. Numa escola tão grande, na é? E olha que aumentou, agora tem até uma certa participação, mas nisso não tinha nenhuma e era a maior dificuldade para passar coisas pelo conselho de escola, porque ninguém vinha.

Lara - Você sabe qual a opinião dos pais sobre o ensino final de nove anos?

Diretora - Eles brigavam um pouco no começo, por exemplo, uma aluna que está na Educação Infantil, pela idade de corte ela fica na educação infantil, mas ela é alfabetizada. o pai veio reclamou, eu expliquei para o pai, mas daí ele optou pelo ensino privado. O ensino privado de São Bernardo já está nesta lei faz tempo. Então o que os municipais fizeram: aqueles que iriam cair no fundamental de nove anos, porque era abril o corte, matricularam na escola particular. Na verdade dá na mesma. Tem vários casos que veio aqui tirou o filho e colocou na escola particular na primeira série. $\mathrm{Na}$ escola particular de primeira série o fundamental de nove anos começou antes e a idade de corte é diferente. Vai entender!

Lara - Você sabe qual o posicionamento dos professores em relação ao ensino fundamental de nove anos se eles apoiaram?

Diretora - Eles estão otimistas em relação a isso porque eles têm mais tempo. É mais tranquilo.

Lara - Já que a escola tinha a educação infantil de cinco anos, não foi pensando em manter o espaço e só transformar aquela sala em primeiro ano?

Diretora - Eu continuei com cinco anos também. Eu tinha turma de cinco anos que era chamada seis, a turma de cinco anos iria para primeira série normal. Essa turma do infantil 
que tinha aqui, ele viriam para a primeira série de qualquer jeito, mas eles vinham para o de oito. Eu tive que dividir pelo ideal. Duas do fundamental 9 e das de 8 . Foi um nó.

Lara - Alguns sobraram?

Diretora - Não. Aqui não tive caso nenhum. Já estavam aqui só deu para dividir Lara - Só um ou outro?

Diretora - O que acontece: todo ano a gente recebe crianças de cinco anos para o infantil. Vem de outra escola. Eu mantive a sala de educação infantil e mais quatro manhã e quatro á tarde. Sendo duas de fundamental de nove anos e duas de fundamental de oito anos e mais três infantil por período. Esse ano eu vou ter 5 salas de infantil 5 e 4 salas de infantil 4, são 9 salas de educação infantil sem contar com o fundamental. Agora o fundamental de nove anos está caminhando, não tem mas idade de corte. Como é de rede quem está vindo para cá na sala de cinco deste ano, automaticamente ano que vem, estão na idade certa para...

Lara - As professoras do infantil participaram da elaboração do currículo do primeiro ano?

Diretora - Ajudaram bastante

Lara - Em que momento?

Diretora - No planejamento.

Lara - Planejaram junto?

Diretora - Mais ou menos, trocaram idéias. E as professoras que ficaram com a turma de fundamental de nove anos principalmente uma de manhã e uma da tarde, em outras redes elas são professoras de educação infantil. Foi um dos critérios de eu ter atribuído a sala, eram professores que vinham do infantil que tinham essa noção de infância. Um professor de quarta série que nunca trabalhou com infantil, vai dar aula expositiva e não combina.

\section{Entrevista com a vice- diretora}

Lara - Há quanto tempo você trabalha aqui nesta escola?

Vice diretora - Nesta escola há um ano e meio e como vice diretora eu comecei neste ano. Antes eu trabalhava na biblioteca eu era professora de apoio.

Lara - Qual é a sua experiência profissional em outros lugares?

Vice diretora - Eu tenho 20 anos de sala de aula, me formei em 1990.

Lara - Qual é a sua formação?

Vice diretora - Magistério, Letras e pós-graduação em gestão e coordenação escolar.

Lara - Você já trabalhou com Educação Infantil?

Vice diretora - Nunca. Só com o fundamental. 
Lara - Como você ficou sabendo da ampliação do ensino fundamental para nove anos?

Vice diretora - Reuniões da Secretaria da Educação já apontavam para o início em São Bernardo do Campo, além disso, através da mídia que dizia que muitos municípios estavam aderindo, mas especificamente através de reuniões da secretaria municipal de educação.

Lara - Você concorda com esta ampliação?

Vice diretora - parcialmente, porque eu acho que ainda a estrutura não é adequada, pensando na nossa realidade, não temos um banheiro adaptado, um parque, mesa, carteira adaptado. É como eu ouvi numa formação estamos trocando o pneu de um carro que está andando. A lei chegou foi implantada, mas o carro não está preparado. A estrutura não está adequada, mas eu acho que com o tempo tudo isso vai melhorando. Porque além da estrutura física, tem a parte documentária. Ainda não temos um currículo. Temos que adaptar o currículo anterior a esta demanda que está aí. Está tudo ainda sendo construído. Por isso eu concordo parcialmente, porque se estivesse tudo estruturado seria bom.

Lara - Quais critérios foram utilizados para a formação das turmas de primeiro ano?

Vice diretora - Não tivemos muitas opções. Foi dado que tínhamos que ter aqui uma quantidade para as duas salas, então não tinha perfil, foi atribuído para duas professoras que achamos ter perfil para trabalhar com estas turmas. Mas a montagem das salas foi aleatória, tivemos crianças daqui e de outra escola de educação infantil que fica próximo à escola. Inclusive tem professoras que dizem que tem uma sala que é mais agitada do que a outra.

Lara - já que aqui na escola já tinha o infantil 5 , foi cogitada a possibilidade de transformar o infantil 5 em primeiro ano ou não?

Vice diretora - Transformar e não ter mais o infantil, não. Nós tínhamos que manter o infantil e só pegar aquelas crianças que, ...porque é só um mês de corte. Eu não sei nem te dizer, mas eu sei que as crianças que estavam naquele mês de corte ele tinha que obrigatoriamente ir para o primeiro ano de nove anos, as crianças daquele mês para trás tinham que ficar no infantil.

Lara - Então são crianças que fizeram mais um ano de infantil?

Vice diretora - Fizeram porque não contemplaram o mês de corte. Eu não sei mais ou menos, mas acho que esta foi uma organização da prefeitura de SBC, até para este ano teve alguma alteração, mudou o mês. Por exemplo, se a criança fosse até 16/03 ela poderia ir, se fosse 17/03 não poderia ir mais. Foi este um dos critérios para montar as salas também.

Lara - Então alguns foram direto para a primeira série?

Vice diretora - Não, eles saíram da Educação Infantil e foram para a primeira série de nove anos. 
Lara - E o de oito, porque tem aqueles que foram para o primeiro ano de oito anos que vieram da educação infantil daqui, não foi?

Vice diretora - Foi a data de aniversário que fez a separação.nascidos em determinado mês, fundamental de oito anos, em determinado ano, nove anos.

Lara - Foram realizadas modificações do espaço físico da escola?

Vice diretora - $\mathrm{O}$ que a gente conseguiu foram mesas e cadeiras, porém o banheiro não é adequado, não temos parque.

Lara - Quais são os objetivos do trabalho com as crianças do fundamental de nove anos?

Vice diretora - Eu acredito que é dar um suporte maior para os anos seguintes, mas ainda com esta opinião eu estou em conflito porque isso já acontece na educação infantil, nesse sentido o que tem sido feita é uma preparação para a alfabetização. Pelo fato deles não terem ainda maturidade não podemos cobrar o mesmo que cobramos das crianças da primeira série do fundamental de oito anos. Estou num conflito, preciso ver como eles estarão no ano que vem para saber o que é melhor. Como não tínhamos currículo específico, adaptamos de acordo com o que tínhamos. Qual foi a indicação apropriação do alfabeto e da sequência numérica para vermos futuramente o que é possível. Inclusive se vocês com esta pesquisa souberem qual o caminho podemos seguir ficaremos bastante agradecidas. Porque ainda não sabemos, tudo é ainda muito confuso, porque estes objetivos já eram trabalhados pelas professoras da educação infantil.

Lara - Como é feita a avaliação dos alunos?

Vice diretora - A avaliação proposta é que seja contínua, no dia-a-dia, de acordo com a diversidade do aluno. Chega o final do bimestre, na reunião do Conselho, as professoras chegam com uma avaliação através da ficha de rendimentos onde se descreve se o aluno é satisfatório ou insatisfatório. Neste caso o coordenador pede aos professores que no seu planejamento semanal observe os aspectos necessários para o desenvolvimento da criança e faça sua avaliação e adaptações de sua prática para que o aluno avance. Então a avaliação é constante, não precisa ter uma atividade pontual para chegar neste diagnóstico. Se chamarmos um professor aqui ele saberá avaliar o aluno porque ele utiliza-se deste processo. Porém eles fazem a sondagem para classificar a hipótese silábica da criança.

Lara - Sobre o Conselho, no primeiro bimestre foi realizado junto primeiros anos e primeiras séries, no segundo bimestre separou. Você sabe dizer por que isso aconteceu?

Vice diretora - Não foi nada intencional, foi por questões de logística, questões de data. Por praticidade, tanto é que no terceiro bimestre foi junto e no quarto também. 
Lara - Sobre o ciclo, na escola vocês têm dois. O primeiro que vai do $1^{\circ}$ ao $3^{\circ}$ e o segundo do $4^{\circ}$ ao $5^{\circ}$ ano. É isso?

Vice diretora - Não, $1^{\mathrm{a}}$ e $2^{\mathrm{a}}$ série de nove anos e $3^{\mathrm{a}}$ e $4^{\mathrm{a}}$ com reprovação no final de cada ciclo.

Lara - Qual foi a reação das crianças ao chegarem no primeiro ano?

Vice diretora - Para as crianças eu não acho que notaram tanta diferença, porque as professoras que estão com estas crianças foram escolhidas a dedo. Eles foram acolhidos de acordo com a idade deles, com o lúdico, adaptamos a brinquedoteca, compramos brinquedos para eles.

Lara - Mesmo os que vieram de outras escolas?

Vice diretora - Mesmo estes. Porque nenhum pai veio aqui reclamar, porque a criança não está acompanhando, porque o filho não está gostando, isso nunca. Eu faço uma avaliação da comunidade, ninguém falou que não está bom, que preferia que o filho estivesse na educação infantil, de dez meses que estou aqui nunca recebi nenhuma reclamação.

Lara - Vocês da direção participaram de algum curso ou de alguma reunião sobre o ensino fundamental de nove anos?

Vice diretora - Eu não, mas a diretora sim, porque eu ainda era da biblioteca.

Lara - Os professores receberam algum material didático da secretaria?

Vice diretora - Não. É essa a defasagem que nós temos. Nós tentamos nos virar com aquilo que tínhamos.

Lara - Neste ano vocês estão participando de reuniões sobre o tema?

Vice diretora - Eu não participei de nenhuma. E se a diretora foi eu tenho escutado ela falar muito pouco. Porque eu não tenho escutado muito sobre isso.

Lara - Os professores dos primeiros anos receberam alguma formação específica?

Vice diretora - Não.

Lara - Nós vimos no livro do HTPC que foi oferecido um curso on line, da editora moderna.

Vice diretora - Que eu saiba este curso era opcional, e pelo que sei, elas não estão fazendo.

Quando a diretora conversou para elas pegarem as turmas elas ficaram apreensivas, mas acabaram aceitando foi um desafio.

Lara - A proposta do ensino fundamental de nove anos foi discutido na escola como um todo? Vice diretora - Em alguns momentos de HTPC sim, para montar as salas a diretora chamou os pais e fez uma reunião explicou como seria, porque é difícil para a comunidade entender esta mudança. A diretora fez duas reuniões para tratar desta nova organização. As professoras 
falam da ansiedade dos pais em relação à ausência de atividades no caderno, lições de casa, que eles tem a mesma expectativa que se tem da primeira série.

Lara - E os professores foram comunicados em HTPC e neste ano?

Vice diretora - Olha neste ano, não conversamos. No ano passado que eu me lembre discutimos mais.

Lara - O que você percebeu da posição dos pais? Eles concordam ou não concordam com esta mudança?

Vice diretora - eu estou entendendo que eles estão concordando porque eu não escuto reclamação ou pelo menos não chega aqui. Se chega no professor não somos informadas e olha que a comunidade é bastante crítica. Tudo o que ocorre eles vem até nós para reclamar. Eu tenho a impressão de que eles estão entendendo o processo.

Lara - E os professores, concordam com a mudança?

Vice diretora - Os professores estranharam, pelo menos os que estão com as crianças sentiram com a falta de estrutura para se trabalhar. Mas isso varia muito, por exemplo, tem uma professora da tarde que se identificou muito com esta faixa etária porque antes ela trabalhava com uma segunda série que ela se desgastou muito e neste ano vemos que até o seu semblante mudou sem contar a turma que está gostando muito do trabalho dela. No caso das professoras do período da manhã elas sentiram mais impacto no sentido da falta de informação em relação aos objetivos que não são claros, porque elas são professoras que trabalharam muito tempo com alfabetização, acredito que no ano que vem será mais tranqüilo para elas.

Lara - As professoras do infantil 5 participaram da elaboração da proposta de trabalho do primeiro ano do ensino fundamental de nove anos?

Vice diretora - Sim elas se encontraram para definir os limites de cada uma, porque elas também entraram em conflito.

Lara - Agora elas fazem separado?

Vice diretora - Sim, isso aconteceu mais no primeiro semestre, mas depois o trabalho foi se encaixando e cada uma seguiu o seu caminho.

Lara - Acho que é isso. Obrigada.

Vice diretora - Agora eu quero dizer que tudo o que disse é muito pessoal, são as minhas impressões. Eu não sei se estou falando bobagem, não tenho muito aprofundamento no assunto.

\section{Entrevista com responsável 1}


Sandra- quantos filhos a senhora tem?

Mãe- dois

Sandra- Quantos estudam nessa escola?

Mãe - Um

Sandra- a senhora mora aqui próximo a escola?

Mãe - próximo

Sandra- Por que a senhora escolheu matricular o Gustavo nessa escola?

Mãe - Porque é a mais próxima da minha casa

Sandra - Você sabia que em 2006 o governo federal criou uma lei onde até 2010 as crianças de seis anos deveriam ser matriculadas no primeiro ano do ensino fundamental e não mais na pre escola, e que com isso o ensino fundamental passará a ter nove anos de duração?

Mãe - Eu soube e acho errado porque eles entram muito cedo na escola

Sandra- A senhora concorda com essa mudança que obrigatoriamente matricula as crianças de seis anos no ensono fundamental e não mais na educação infantil, e que ampliou o ensino para nove anos, por que?

Mãe - não concordo exatamente por isso, porque eu acho eles muito novos, são muito criança ainda para entender a primeira série, né?!

Sandra - o seu filho cursou a educação infantil?

Mãe - três anos

S- Que diferenças a senhora percebe entre a educação infantil e a escola atual?

Mãe - é basicamente quase que a mesma coisa, é que aqui tem mais atividade pra ele levar pra casa, mas o que ele fazia lá ele faz aqui tb.

Sandra - Se você pudesse escolher manteria seu filho de seis anos na educação infantil ou no ensino fundamental?

Mãe- no infantil

Sandra - Por que?

Mãe - Porque eu estou vendo que o desenvolvimento dele não está sendo muita coisa, está sendo quase a mesma coisa que o infantil.

Sandra - Em sua opinião, o que é uma escola boa pras crianças de seis anos?

Mãe - na minha opinião... eu acho assim, que em primeiro lugar deveria ser mais do que um professor na sala de aula, pra eles aprenderem melhor.

Sandra - Você acha que seu filho está gostando da escola?

Mãe - Tá

Sandra - Por que, quais são as manifestações dele, o que a senhora acha que ele... 
Mãe - Ele está mais interessado em aprender a ler e escrever, e está assim no meio dos amiguinhos

Sandra - Como a senhora ficou sabendo das mudanças, da entrada dele ao invés de na préescola, no primeiro ano?

Mãe - Através de uma reunião na escola

Sandra - Aqui na escola?

Mãe - na escola

Sandra - A senhora conhece a proposta de trabalho para esse primeiro ano, se é diferente da primeira série?

Mãe - É basicamente a mesma coisa o que a professora explicou pra gente, não tem muita diferença

Sandra - e a senhora participou da elaboração ou só foi informada?

Mãe - nós fomos só informados

Sandra - Em que momento você vem à escola, a senhora participa de conselho de escola ?

Mãe - não, só nas reuniões

Sandra- Tá bom! Muito obrigada!

Mãe - de nada

\section{Entrevista com responsável 2}

Lara - Você é a mãe da?

Mãe - Ellen

Lara - E quantos filhos você tem?

Mãe - Só ela

Lara- Só ela, e você mora aqui próxima a escola?

Mãe - sim

Lara - Qual é o nome do bairro?

Mãe - aqui mesmo

Lara - E por que você escolheu matricular ela nessa escola?

Mãe - porque a escola é nova, né, e, apesar de ter ouvido mal, falei vamos ver como é, e coloquei ela, até então nenhuma reclamação, escola próxima é melhor pra acompanhar ela.

Lara - E você sabia que em 2006 o governo federal criou uma lei onde até 2010 as crianças de 6 anos deveriam ser matriculadas no primeiro ano do Ensino Fundamental e não mais na 
educação infantil, na pré escola e com isso o ensino fundamental passou a ter nove anos de duração?

Mãe - Não, foi explicado isso ano passado pra gente, sabendo que até como ela está na primeira série já do ensino fundamental.

Lara- Ano passado em que momento

Mãe - quando ela estava na sala de cinco anos, no pré, de quatro anos pra cinco anos no pré, dai falaram, ela não vai pra sala de cinco anos, a partir do ano que vem já é primeiro ano.

Lara- quem que te falou?

Mãe - a professora dela do prezinho

Lara- tá, e você concorda com essa mudança?

Mãe - eu vou falar particularmente com a Ellen eu gostei porque ela desenvolveu muito mais, mas na sala dela tem crianças com dificuldade, daí eu não concordo igual a professora falou, por ela, ela trabalha diferente com essas crianças porque elas estão acostumadas a estar brincando, desenhando, então é um pouco de lição mas ... durante cinco horas é muita tortura para eles, a professora falou a gente faz um trabalho diferente com eles, mas ainda tem crianças de acordo com a professora que estão tendo dificuldades, até ela falou que é perigoso até repetir porque tem crianças que o que as outras já sabem elas não sabem nem o começo Lara- ela cursou a educação infantil

Mãe -cursou

Lara- e que diferença que você percebe entre o que ela fazia antes no infantil cinco e o que ela está fazendo agora no primeiro ano?

Mãe - ela amadureceu mais, amadureceu muito mais, ela já está mais comportada, quer se comportar igual gente grande, passa as coisas ela fica lendo quer ler mais, antigamente ela só queria brincar, correr, ficar sentada assistindo televisão, agora ela gosta de ler bastante, desenhar, fazer lição, ela gosta de livrinho, então deu amadurecida a mais.

Lara- E aqui na escola das atividades que ela tinha e que ela tem agora, o que você percebeu?

Mãe - Tudo normal, mas as vezes melhor, amava, ama biblioteca, ama brincar em grupo, cada vez melhor

Lara- e se você pudesse escolher, a Ellen, você deixaria ela na educação infantil ou prefere que ela esteja no ensino fundamental mesmo

Mãe - gostaria

Lara- na educação infantil?

Mãe - na educação infantil

Lara- por que? 
Mãe - Porque... não sei, porque você... tipo assim, não que eu deixaria, no começo eu achei que fosse judiação, mas hoje depois que passou eu deixaria, é que a gente não tem como saber como vai ser, então...assim...é complicado, não tenho assim uma resposta específica, no começo eu não deixaria, quando eu fiquei sabendo

Lara- no fundamental?

Mãe - quando eu fiquei sabendo, se eu pudesse dizer eu ia falar não, deixa ela fazer mais um ano de pré, mas se for observar no desenvolvimento dela como criança foi muito bom Lara - na sua opinião o que é uma escola boa para as crianças de seis anos, o que você considera importante que ela faça, que ela aprenda

Mãe - Bom, na escola boa em primeiro lugar o professor é bom, não pode ser como era a professora dela. A professora dela é organizada , passa as lições (?), da atenção, fica encima das crianças que tem mais dificuldade, então pra mim é isso. Em primeiro lugar o professor. A escola boa tem que ter um professor bom que ensine a criança, que tenha interesse

Lara- e você ficou sabendo sobre a mudança no ano passado

Mãe - foi

Lara - Você conhece a proposta de trabalho para o primeiro ano, você participou da elaboração do que ela ia fazer e em qual momento?

Mãe - como assim elaboração?

Lara- a proposta, o que ela vai fazer esse ano, você ficou conhecendo?

Mãe - ah, ela passou logo no início de ano, ela passou tudo, ela até deu uma acelerada, porque eles tem uma meta com as crianças de seis anos, que por estar sendo novidade eles não podem estar forçando as crianças, mas ela falou que já deu ua boa avançada até março, ela já conseguiu dar uma boa avançada, então ela passou direitinho pra gente e no decorrer dass reuniões ela vem passando o desenvolvimento de cada criança, conversando com a gente, conversa com os pais das crianças que tem dificuldade, ela fala, olha isso daqui não tem problema, ela sabe até a margem que a gente quer.

Lara- e quando que você vem aqui pra escola?

Mãe - Sempre, tudo que tem aqui eu estou aqui, trago ela na escola, se tem atividade no final de semana com a família a gente vem, se tem apresentaçãozinha da sala dela a gente vem, se tem reunião de pais sempre sou eu, to sempre aqui

Lara - do conselho de escola você participa aqui ou não

Mãe - Não, a APM não

Lara - tá 
Mãe - não, é a única coisa que eu não participo, não venho não, eu não me interesso pela APM

Lara- muito obrigada então, me ajudou bastante, obrigada

Mãe - de nada

Lara- tchau tchau, muito obrigada

\section{Entrevista com responsável 3}

Lara - Você é mãe da...

Mãe - ingrid

Lara - da Ingrid né, e quantos filhos você tem?

Mãe - Três

Lara- E quantos deles estudam nessa escola?

Mãe - Dois

Lara- Você mora próximo aqui a escola?

Mãe - moro

Lara - Por que você escolheu matricular sua filha nessa escola?

Mãe - Porque é a mais perto

Lara- è mais perto... e você sabia que em 2006 o governo federal criou uma lei onde até 2010 as crianças de seis anos deveriam ser matriculadas no primeiro ano do ensino fundamental e não mais na educação infantil, na pre-escola, e que com isso o ensino fundamental passou a ter nove anos de duração?

Mãe - Sabia

Lara - Você ficou sabendo... e você concorda com essa mudança?

Mãe - Concordo

Lara - Por que você concorda?

Mãe - Eu acho bom as crianças já aprenderem desde cedo assim

Lara - O que você acha que ela aprende assim?

Mãe - A Ingrid já aprendeu bastante coisa já... a ler as palavras, a juntar as sílabas, tudo...

Lara -Ela cursou a educação infantil, que é a pre-escola? Quantos anos?

Mãe - Ela fez desde os dois anos que ela ficou na creche.

Lara - Ah ta, e você percebe diferença entre o que ela aprendia na educação infantil e aqui no primeiro ano?

Mãe - bastante 
Lara - que tipo de diferença?

Mãe - Ela desenvolveu mais, também por causa da idade, e ela está lendo já algumas coisas, em casa pelo menos, porque ela é muito tímida, e numerais, ela gosta, ela, tipo assim, a professora passa umas palavras para ela, pra ler em casa, pra depois ler na escola, aí eu comecei a ensinar ela, e daqui a pouco ela já está lendo sozinha

Lara - que bonitinha... e se você pudesse escolher, preferia ter mantido ela na educação infantil com seis anos, como era antigamente, ou você preferia que ela estivesse mesmo no primeiro ano?

Mãe - não, no primeiro ano

Lara - na sua opinião, o que é uma escola boa para crianças de seis anos, o que você considera que é importante que ela faça, aprenda na escola, com seis anos.

Mãe - Tudo que eu acho que é bom ela já está aprendendo

Lara - então você gosta do que ela aprende aqui... como você ficou sabendo da mudança, sobre a entrada da sua filha no ensino fundamental que agora ia ter nove anos?

Mãe - No dia da primeira reunião eles falara, porque eu até então não entendia direito, aí depois...

Lara - quem falou foi a professora?

Mãe - foi, mas não era a Denise, a Denise estava de resguardo ainda

Lara - Por causa do neném né?

Mãe - é

Lara - e ela antes fazia o infantil cinco aqui ou fazia em outra escola?

Mãe - La no Roberto Dias, aqui próximo.

Lara- só esse ano ela começou aqui?

Mãe - Só esse ano

Lara- E você conhece a proposta de trabalho do primeiro ano, você participou da elaboração da proposta com a professora?

Mãe - Não, porque eu só vim na primeira reunião, assim, porque eu trabalho ao noite então fica muito difícil deu vir né... mas sempre que dá eu tô vindo conversar com a professora, mas não sobre isso

Lara- Aí a professora explicou o que vai ter no primeiro ano, na primeira reunião?

Mãe - É, explicou, mas não me pergunta agora que eu não lembro...

Lara- E em que momento que você vem então a escola, você falou que vem quando pode...

Mãe - Igual, esse horário assim eu venho, na hora que eu venho buscar também, quando eu não estou dormindo eu venho buscar, aí eu converso com a professora quando eu vejo que ela 
fica cobrando, a Ingrid cobra também, no dia da reunião mesmo não deu pra mim vir, nossa, ela chorou tanto

Lara- Ah é?!

Mãe - Mãe, você não foi na minha reunião e começou a chorar, ai meu Deus do céu viu...

Lara - E conselho de escola aqui, você participa?

Mãe - Não, não dá né, por causa do horário de trabalho

Lara- Seu filho está em qual série, o outro?

Mãe - Está na quarta, a tarde

Lara- Quarta série... então tá bom, muito obrigada viu...

Mãe - de nada

\section{Entrevista com responsável 4}

Sandra - Você é mãe de quem?

Mãe - Rayane

Sandra - Quantos filhos você tem?

Mãe - Quatro

Sandra - Quantos estudam nessa escola?

Mãe - Só um

Sandra - A senhora mora próximo a escola?

Mãe - Moro no Bairro

Sandra - Por que a senhora escolheu matricular os seus filhos aqui na escola?

Mãe - Porque é a escola do nosso Bairro. Eu não conhecia a escola, porque nenhum filho meu estudou aqui. A gente tem que valorizar aquilo que é da gente. Todos os meus filhos estudaram aqui no Batistini.

Sandra - Você sabia que em 2006 o governo federal criou uma lei que até 2010 as crianças de seis anos deviam está no primeiro ano do ensino fundamental?

Mãe - Não sabia

Sandra - O que a senhora acha dessa mudança?

Mãe - Eu concordo porque as crianças hoje estão muito evoluídas, muito inteligente

Sandra - A Rayane cursou a educação infantil?

Mãe - Cursou

Sandra - Que diferença você percebe na educação infantil para o ensino fundamental?

Mãe - Na pré-escola era mais brincadeira e aqui é coisa séria 
Sandra - Se a senhora pudesse manteria sua filha de seis anos na educação infantil ou no fundamental?

Mãe - Ficaria do jeito que está.

Sandra - Por que?

Mãe - Porque ela está na idade de aprender mais, de aprender a ler, escrever para o bem dela.

Sandra - Em sua opinião, o que é uma escola boa para criança de seis anos?O que tem que ter nessa escola?

Mãe - Está bom do jeito que está. Eu gosto da escola, não tenho o que reclamar, é o primeiro ano que ela está aqui, ela está indo bem, está aprendendo, está quase lendo, sabe escrever. Está bom assim. Na minha opinião ela está boa.

Sandra - A senhora acha que sua filha está gostando da escola?

Mãe - Ela está gostando da escola

Sandra - Como que a senhora percebe isso?

Mãe - Porque todos os dias quando ela acorda ela pergunta: "Hoje tem escola? Ôba! Então ela gosta.

Sandra - Como a senhora ficou sabendo mudança da entrada da sua filha no ensino fundamental de nove anos, que ele não ficaria mais no infantil, mas que...

Mãe - Foi ano passado quando eu recebi o papelzinho para receber a matrícula dela na outra escola.

Sandra - A senhora conhece a proposta de trabalho no primeiro ano?

Mãe - Não

Sandra - E também não participou da elaboração?

Mãe - Não

Sandra - Em que momento você vem na escola, se participa de reuniões, participa do conselho.

Mãe - Só nas reuniões mesmo, porque eu trabalho no período escolar dela e quando eu posso eu trago ela na escola.

Sandra - A senhora não participa do conselho?

Mãe - Não.

\section{Entrevista com responsável 5}

Lara - Bom dia, a senhora é a mãe do... 
Mãe - Kainan

Lara -Quantos filho você tem?

Mãe -Três

Lara - e quantos estudam nessa escola?

Mãe - Dois

Lara -qual que é a série do outro?

Mãe - Não, o outro não estuda mais aqui não, mudou, já está terminando, já está no Mathias

Lara - E você mora próximo a escola?

Mãe -Moro

Lara -O nome do bairro é Battistini?

Mãe -É

Lara - E porque que você escolheu matricular seu filho nessa escola?

Mãe - Porque é mais próximo, a gente mora aqui, é morador aqui, os outros três, todos eles já estudaram aqui né, os outros dois, eu sempre ponho aqui, só sai quando termina o...

Lara - Dois deles já passaram aqui?

Mãe - Já passaram por aqui já, quando vai pra quinta que vai pro Mathias...

Lara - Tá, e você saba que em 2006 o governo federal criou uma lei onde até 2010, esse ano, as crianças de seis anos deveriam ser matriculadas no primeiro ano do ensio fundamental, e não mais na educação infantil, na pre-escola, e que o ensino fundamental passou a ter nove anos de duração?

Mãe - É,o Kainan já entrou nessa etapa aí

Lara - Como que você ficou sabendo da mudança?

Mãe - Aqui, aqui mesmo na escola.

Lara - Quem que contou?

Mãe - Na reunião de pais.

Lara - Foi a professora Denise né?

Mãe - é

Lara - E você concorda com essa mudança que obrigatoriamente matricula as crianças no ensino fundamental e não mais no infantil?

Mãe - Ah, eu acho assim que pra eles fica melhor porque termina mais cedo, não é, eu penso assim que é melhor pra eles porque termina mais cedo

Lara - já começa...

Mãe - já começa, é... 
Lara - É que ampliou um ano né, então na verdade eles também vão fazer em nove, e não mais em oito

Mãe -É, já adianta um ano

Lara - E o seu filho cursou educação infantil, ele fez pre-escola?

Mãe - Fez

Lara - Onde ele fez?

Mãe - No Roberta.

Lara - E que diferença você percebe entre a educação infantil e a escola atual?

Mãe - Ah, desenvolve mais.

Lara-Qual?

Mãe - Aqui. Tem mais desenvolvimento.

Lara - Porque você acha que ele tem mais desenvolvimento?

Mãe - Porque quando eles estão com as crianças maiores eles se desembaraçam mais, com as crianças pequenininhas eles brincam mais e aqui não porque é um pouco mais esforçado ele se desenvolveu bem melhor.

Lara - Se você pudesse escolher, você deixaria ele na educação infantil por mais um ano ou matricularia no ensino fundamental?

Mãe - Não, eu acho que dá para passar para o segundo.

Lara - Não, se fosse no começo do ano. Você preferia que ele ficasse no infantil ou estudasse no primeiro ano?

Mãe - não, não. Eu preferia que ele ficasse na Infantil.

Lara - Porque?

Mãe - Porque eu acho que para ele, eu acho que era melhor ficar mais, porque neste primeiro ano ele pegou só algumas coisas, se ele ficasse lá mais um ano ele viria com mais facilidade para cá.

Lara - Na sua opinião o que é uma escola boa para crianças com a idade de 6 anos?

Mãe - Aqui para mim é uma escola boa, só está faltando um parquinho, mas aqui eu acho uma escola boa.

Lara - O que você gosta que ele faz aqui?

Mãe - As atividades. Eu não tenho o que reclamar.

Lara - E você conhece a proposta de trabalho do primeiro ano? O que a professora trabalha com eles no primeiro ano?

Mãe - Não. Ela desenvolveu bastante atividades com eles, trabalhos, apresentação. Meu filho era tímido e desenvolveu bastante. Foi bom. 
Lara - Em que momento você vem aqui para a escola?

Mãe - Nas reuniões eu sempre participo.

Lara - Você faz parte do Conselho de Escola?

Mãe - Não, mas nas reuniões de pais eu sempre participo.

\section{Entrevista com responsável 6}

Lara - Você é pai de quem?

Pai - Do Kauã.

Lara - Quantos filhos o senhor tem?

Pai - Tenho três filhos.

Lara - Quantos estudam nessa escola?

Pai - Só o Kauã.

Lara - O senhor mora próximo a escola?

Pai - Moro, $1 \mathrm{~km}$ mais ou menos.

Lara - Por que o senhor escolheu matricular os seus filhos aqui na escola?

Pai - Porque é mais próximo e eu nunca ouvi falar mal desta escola.

Lara - Você já conhecia a escola?

Pai - Conhecia, moro a mais de dez anos aqui no bairro.

Lara - Você sabia que em 2006 o governo federal criou uma lei que até 2010 as crianças de seis anos deviam estar no primeiro ano do ensino fundamental e que o ensino fundamental passou a ter nove anos de duração?

Pai - Eu não ouvi sobre esse assunto.

Lara - O que o senhor concorda com essa mudança?

Pai - Concordo, se é para o benefício da criança.

Lara - O senhor diz que é benefício por quê?

Pai - Porque já ajuda bastante. Como é que é que a senhora está falando?

Lara - Ao invés de ir para a educação infantil elas começam a primeira série mais cedo.

Pai - Ah, não. Eu não concordo, deveria ser como antigamente, primeiro, segundo, terceiro e assim por diante.

Lara - Para você deveria ter educação infantil antes?

Pai - Sim.

Lara - Por que?

Pai - Porque você avança cada vez mais, eu prefiro com mais calma do início até... 
Lara - O Kauã cursou a educação infantil?

Pai - Cursou.

Lara - Que diferença você percebe na educação infantil para o ensino fundamental?Vc acha que melhorou?

Pai - Ele melhorou bastante e muito.

Lara - Por que?

Pai - Vai muito da professora, tem professora que paciente, a professora que ele está eu só tenho que elogiar.

Lara - Se senhor pudesse manteria o seu filho de seis anos na educação infantil ou no fundamental?

Pai - Preferia que ele continuasse no infantil, para melhorar mais um pouco. Acho que é muito precoce para ir para o primeiro ano.

Lara - Em sua opinião, o que é uma escola boa para criança de seis anos?O que tem que ter nessa escola?

Pai - Em primeiro lugar segurança, boa merenda, boa comida, boa professora e diretora.

Lara - E o que o senhor acha que ele deveria fazer na escola?

Pai - Brincasse, fizesse desenho, criatividade, uma porção de coisas que tivessem benefícios para ele.

Lara - O senhor acha que o sue filho está gostando da escola?

Pai - Está. Ele elogia bastante a escola, os coleguinhas, a professora.

Lara - Você não sabia até hoje?

Pai - Não sabia, não li no jornal sobre esse programa.

Lara - Aqui na escola também não?

Pai - Não comentaram comigo, já vim em várias reuniões, não comentaram.

Lara - Você conhece a proposta de trabalho do primeiro ano?

Pai - Não, tem que alguém me explicar porque eu também não vi.

Lara - E quando você costuma vir aqui na escola?

Pai - Nas reuniões, geralmente sou eu que venho.

Lara - E no Conselho de Escola?

Pai - Não, só nas reuniões de pais. Já vim para assistir os trabalhos deles.

\section{Entrevista com responsável 7}


Sandra - Quantos filhos o senhor tem?

Pai - Dois

Sandra - Quantos estudam nessa escola?

Pai - Um

Sandra - O senhor mora perto da escola?

Pai - Moro

Sandra - Qual Bairro?

Pai - Battistini

Sandra - Por que o senhor escolheu matricular o seu filho aqui nessa escola?

Pai - É fácil o acesso, fica perto de casa e a informação que eu tive da escola é boa.

Sandra - Você sabia que em 2006 o governo federal criou uma lei que até 2010 as crianças de?

Pai - Eu ouvi dizer.

Sandra - O senhor concorda com essa mudança?

Pai - Concordo

Sandra - Por que?

Pai - A faixa da criança fora da escola ela só tem a perder a situação mais de idade. Porque a escola, as crianças a gente ver na rua, com liberdade e aprontando. Ficando na escola é menos tempo de ficar na rua

Sandra - O seu filho cursou a educação infantil?

Pai - Cursou

Sandra - Quais as diferenças que o senhor notou entre o que ele prendia o que ele fazia na educação infantil e o que ele está fazendo agora?

Pai - Ele pega mais intimidade em sair de casa e ir para a escola não é tanto que vai aprender aquela coisa toda, mas aprende também. Até porque ele já sabe ler, sabe fazer conta e assim ele vem caminhando desde o começo. É bom.

Sandra - Se o senhor pudesse escolher o senhor manteria o Osmar na educação infantil ou no ensino fundamental?

Pai - Eu manteria na mesma sequência que está.

Sandra - No ensino fundamental?

Pai - Sim

Sandra - O que o senhor acha melhor que ele esteja agora no ensino fundamental e não na educação infantil? 
Pai - Nesse caso das condições dele, ele já poderia está mais adiantado ele já aprendeu bastante na escola e a gente também ensina em casa. Tem muitas crianças não chega a competir no nível que ele está porque o Pai - e mãe não tem tempo de ensinar. Aí já faz falta se ele não começa desde a parte inicial dele.

Sandra - Na sua opinião o que é uma boa escola da faixa etária do Osmar?

Pai - Na minha opinião a escola é aquela que tudo começa bem quando tem funcionários bons, professores com alta competência de lhe dá com crianças não deles e ensinar aqueles que sabe que é para ensinar, pode não saber ensinar mas sabe que é para ensinar. Até eu que não sou professor sei disso e todos funcionários todas as pessoas deveriam ser mais responsáveis na escola, a gente ver que não é. Infelizmente esse fracasso. Eu não sei se em outras escolas têm, mais aqui nessa parte deixa a desejar.

Sandra - O senhor acha que seu filho está gostando da escola?

Pai - Está sim

Sandra - Como é que o senhor percebe isso?

Pai - Ele chega em casa contando casos dos amiguinhos dele e a gente vê que ele quando chega a hora ir para escola, vai de boa vontade. Ele gosta.

Sandra - Como o senhor ficou sabendo da entrada dele no primeiro ano?

Pai - Eu achei meio desajeitado, eu não concordei tanto porque tipo que está atrasando um ano de escola da criança. É como se ele tivesse que ser forçado a reprovar um ano, repetir um ano. Mas a gente sabe que um ano depois tem o caso dele e tem o caso de outroSandra - Para muitos que não conseguem aprender rápido no início aprendia no básico e depois fica mais fácil.

Sandra - O senhor conhece a proposta de trabalho feita no primeiro ano?

Pai - Não

Sandra - O senhor também não participou da elaboração dessa proposta

Pai - Também não

Sandra - Em que momento o senhor vem a escola, o senhor participa do conselho...?

Pai - Geralmente eu venho nas reuniões, se eu não puder vir, minha esposa vem. Geralmente vem até nós dois para ouvir a mesma conseqüência nós dois, seu eu ouvir a história e entender de um jeito e ela também ouvir a história e entender de outro, depois conversamos nós dois para encaixar, ver se é aquilo mesmo. Às vezes as pessoas falam para um grupo de pessoas, a explicação é a mesma, mas o jeito de entender é diferente. A gente participa muito.

\section{Entrevista com responsável 8}


Sandra - Quantos filhos você tem?

Mãe - Dois

Sandra - Quantos estudam nessa escola?

Mãe - Dois

Sandra - A senhora mora próximo a escola?

Mãe - Não

Sandra - Qual Bairro que a senhora mora?

Mãe - É aqui no Bairro, só que é em chácara, é afastado.

Sandra - Por que a senhora escolheu matricular os seus filhos aqui na escola?

Mãe - Porque é mais próximo de minha casa.

Sandra - Você sabia que em 2006 o governo federal criou uma lei onde até 2010 as crianças de seis anos deveriam ser matriculadas no ensino fundamental e não mais na educação infantil?

Mãe - Fiquei sabendo agora quando coloquei o Thiago. Até então não entendi muito como funciona isso.

Sandra - A senhora concorda com essa mudança?

Mãe - Concordo em parte, pois a partir do momento que você não force a criança a sair do limite dela, eu concordo, como no caso da Camila que no ano que vem com seis anos ela vai para o primeiro ano. Ela está desenvolvendo bem. Então quer dizer: aí sim eu concordo, mas se a criança não consegue desenvolver, não adianta forçar, tem que deixa ela seguir o ritmo dela..

Sandra - O Thiago cursou a educação infantil, a pré escola?

Mãe - Sim, um ano

Sandra - Quais as diferenças que a senhora notou entre o que ele prendia o que ele fazia na educação infantil e o que ele está fazendo agora?

Mãe - No caso do infantil, ele não levava muito a sério. Era mais brincadeira. Agora não, ele chega e diz: - "Mamãe, tem lição a gente precisa fazer". Então assim, mãe vem me ajudar a fazer a lição, tem que levar. Ele está pegando um pouquinho mais de responsabilidade em relação a matéria da escola.

Sandra - Se a senhora pudesse escolher, a senhora manteria o Thiago na educação infantil ou no ensino fundamental?

Mãe - Do jeito que está.

Sandra - Por que? 
Mãe - Porque ele está desenvolvendo bem entendeu? Ele está... Aprendendo, não estão forçando ele. Eu converso muito com a professora e falo para ela: - Eu quero que respeite o limite dele, não dá, não adianta forçar passar de um a mil; você tem que copiar porque você tem que aprender. Eu não aceito isso. Então assim ele está aprendendo lentamente. Só ele vai se desenvolvendo, quando ele chegar na quinta série ele estará preparado. Ele está aprendendo bem. Se ele estivesse no infantil, não teria aquela responsabilidade da lição, de falar: mãe eu preciso aprender escrever o nome da escola e chegar em casa é quer treinar, no caso dela isso não acontece.

Sandra - Em sua opinião o que seria uma escola boa para criança de seis anos?

Mãe - Aí você me pegou, mas para mim a escola aqui está ótima, eu faço parte do conselho, da APM, estou sempre atenta a tudo, converso bastante com a Ana a gente sempre entra no acordo. Para mim aqui está excelente. A prioridade também é um pouquinho os professores. No caso dos meus, elas são maravilhosas, não conheço as outras. A professora dá aquele suporte para as crianças, no meu caso não tenho o que reclamar porque elas dão.

Sandra - A senhora acha que o Thiago está gostando da escola?

Mãe - Ele está porque ele está sempre querendo vir. Eu sempre converso com ele. Apesar de que a primeira escola dele foi essa.

Sandra - A senhora conhece a proposta de trabalho do primeiro ano?

Mãe - Não. Está aí uma coisa que eu preciso conhecer.

Sandra - Você também não participou da elaboração dessa proposta?

Mãe - Não

Sandra - A senhora disse que participou do conselho, então a senhora está sempre participando de tudo?

Mãe - Tudo que pertence a ele e dos outros alunos também, dentro do meu limite, as vezes tem reunião eu não posso vim, fico a desejar.

\section{Entrevista com responsável 9}

Sandra - Você é mãe de quem?

Mãe - Cláudio

Sandra - Quantos filhos você tem?

Mãe - Três

Sandra - Quantos estudam nessa escola?

Mãe - Dois 
Sandra - A senhora mora próximo a escola?

Mãe - Moro

Sandra - Qual Bairro?

Mãe - Battistini

Sandra - Por que a senhora escolheu matricular os seus filhos aqui na escola?

Mãe - Porque é mais perto

Sandra - Você sabia que em 2006 o governo federal criou uma lei que até 2010 as crianças de seis anos deviam está no primeiro ano do ensino fundamental?

Mãe - Não

Sandra - O que a senhora acha dessa mudança?

Mãe - Eu acho que a criança entra cedo na escola, deveria ta no pré ainda.

Sandra - O Cláudio cursou a educação infantil?

Mãe - Cursou.

Sandra - Que diferença você percebe na educação infantil para o ensino fundamental?

Mãe - No ensino fundamental eu não percebi muita diferença porque eles brincam como se fossem pré. Eles brincam mais do que fazem atividade.

Sandra - Se você pudesse manteria o seu filho de seis anos na educação infantil ou no fundamental?

Mãe - No infantil

Sandra - Por que?

Mãe - Eu acho que é melhor para a faixa etária dele. No caso dele, ele só vai fazer sete anos lá no final do ano. Então até ele começar ingressar igual as outras crianças do primeiro ano demora mais

Sandra -Em sua opinião, o que é uma escola boa para criança de seis anos? O que tem que ter nessa escola?

Mãe - Tem que ter várias atividades extras, fora da sala de aula. Não só atividade na sala de aula, mas como outras atividades fora. E tem pouca aqui na escola.

Sandra - Que tipo de atividade você considera assim interessante?

Mãe - Aula de física, teatro, essas coisas assim, curso

Sandra - Você acha que o seu filho está gostando da escola?

Mãe - Da escola acho que sim.

Sandra - Como que você percebe isso?

Mãe - Porque ele fala

Sandra - Fala bastante? 
Mãe - Fala, fala da professora, dos amigos, fala bastante.

Sandra - Como você ficou sabendo mudança da entrada do seu filho no ensino fundamental de nove anos, que ele não ficaria mais no infantil, mas que...

Mãe - Teve uma reunião na escola, eles avisaram no comecinho das aulaSandra -

Sandra - E você conhece a proposta de trabalho no primeiro ano?

Mãe - Não

Sandra - E também não participou?

Mãe - Não

Sandra - Em que momento você vem na escola, se participa de reuniões, participa do conselho?

Mãe - Do conselho eu não participo porque eu não tenho tempo, mas todas as reuniões eu venho e eu sempre estou aqui na escola, procuro saber como é que ele anda na escola, minha filha também, pergunto para a professora, converso com os inspetores também. Participei do projeto: Tempo de escola.

\section{Entrevista com crianças - grupo 1}

Meu nome é Lara, eu tenho 24 anos. Quantos anos vocês tem?

Criança 1 - eu tenho 7 anos.

Criança 2 - eu tenho 7 anos.

Criança 3 - eu tenho 6 anos.

Criança 4 - eu tenho 7 anos.

Criança 1 - Ele está mentindo, ele não tem 7.

Criança 4 - Eu tenho 7.

Criança 1 - Mentira.

Lara - Mas, você vai fazer aniversário neste ano?

Criança 4 - Vou.

Lara - Então tá bom. E vocês sabem por que eu estou aqui? É porque eu tenho um amigo que se chama Sebastião.

Crianças (em coro) - Sebastião?

Lara - Isso, e ele nunca foi para a escola, para nenhuma escola. E ele tem seis anos e a mãe dele vai colocar ele na escola, só que ele está meio nervoso porque ele não sabe o que vai ter na escola, não sabe se ele vai gostar da escola, o que ele vai fazer na escola, Por isso ele precisa que crianças que tem a idade dele, contem para ele o que ele vai fazer na escola. 
Vocês podem contar para ele? Vocês podem ajudar o Sebastião?

Criança 1 - Eu posso.

Lara - Então, conta para mim. O que vocês fazem aqui na EMEB?

Criança 1 - Primeiro a gente entra, guarda o material e começa a fazer as lições

Criança 3 - Nós ora, depois a gente começa a fazer a lição. Depois que a gente faz a lição nós almoça, vai no parque e depois a gente volta para sala para fazer a lição.

Criança 1 - E quando acaba a gente brinca.

Lara - Vocês brincam? E o que vocês gostam de fazer nesta escola?

Criança 3 - Eu gosto de continha.

Criança 1 - Eu gosto de desenhar.

Lara - E você?

Criança 2 - Eu gosto de fazer lição.

Criança 1- Eu gosto de fazer continha de matemática.

Criança 4 - Eu gosto de brincar na quadra.

Criança 1 - E de fazer coisas de matemática.

Lara - E você?

Criança 3 - Eu gosto de jogar basquete na quadra.

Lara - E o que tem aqui na escola para a gente contar para ele?

Criança 1 - lição

Criança 3 - tem brinquedo.

Criança 4 - Biblioteca de brinquedo

Lara - Biblioteca de brinquedo?

Criança 4 - Sim.

Criança 3 - Brinquedoteca!

Criança 1 - E também tem coisa de almoço, mas eu não como, não. Porque eu como em outro lugar.

Criança 4 - E tem também...

Lara - O que tem?

Criança 4 - Tem biblioteca de livros.

Criança 3 - Tem suco.

Criança 4 - Informática.

Criança 3 - Banana, maçã, pêra.

Lara - E o que vocês não gostam nesta escola?

Criança 1 - Eu não gosto de muita lição. 
Criança3 - Eu não gosto de brigar, de bater.

Criança 1 (apontando para o colega) - Mas você briga com as pessoas!

Criança 3 - Eu brigo quando eles me batem.

Criança 2 - Eu não gosto que as pessoas fiquem brigando.

Lara - E você?

Criança 4- Eu gosto de muitas coisas.

Lara - Tem alguma coisa que você não gosta?

Criança 4 - Eu gosto da quadra, mas a professora não vai na quadra.

Lara - Porque você acha que ela não vai na quadra?

Criança 4 - O prefeito entregou a bola, mas ela não quer pegar a bola.

Criança 1 - Ôh, Lara. Ele também briga com as pessoas na sala ou no coisa.

Criança 3 - No meu primeiro ano eu apanhava quase todo dia dele.

Criança 1 - No meu primeiro ano eu fiquei assustada.

Lara - Se vocês pudessem mudar alguma coisa aqui na escola, o que vocês mudariam?

Criança 3 - Se eu fosse presidente desta escola eu ia mudar as lousas, eu ia colocar maior.

Larissa - Já tem maior na nossa sala.

Criança 3 - Mais eu ia mudar, na biblioteca eu ia colocar uma televisão, eu ia colocar uma telona.

Criança 1 - Eu também sei. Se eu fosse presidente desta escola eu ia mudar para a gente ir na brinquedoteca nos finais de semana e nas sextas-feiras.

Criança 3 - eu também ia querer que a gente ia para quadra todo dia.

Lara - E você?

Criança 2 - (silêncio)

Lara - E você?

Criança 4 - Se eu fosse prefeito desta escola eu ia transformar a quadra em "mais grande".

Criança 1 - Porque você trouxe estojo?

Lara - Eu vou emprestar para vocês daqui a pouquinho. Agora, vocês acham que crianças como vocês de 6 anos tem que ir para a escola?

Crianças (em coro) - Tem.

Lara - Porque vocês acham que elas devem ir para escola?

Criança 1 - Porque é para ensinar.

Criança 2 - Para aprender.

Criança 3 - Para não falar palavrão. Igual o Thiago fala.

Criança 1 - O Thiago come borracha. Mas não pode comer. E também na escola tem que ter 
educação e aprender várias coisas.

Criança 3 - Ah! Tem que respeitar os mais velhos, tem que respeitar a professora.

Lara - E o que vocês acham que tem que fazer na escola?

Criança 4 - Tem que obedecer a professora.

Lara - E o que vocês acham que deveria ter numa escola muito boa?

Criança $2-\mathrm{Eu}$ acho que as crianças tinham que ficar até 5 horas da tarde nela.

Lara - E o que você ia ficar fazendo até 5 horas da tarde na escola?

Criança 2 - Fazer lição, brincava, almoçava.

Criança 3 - Eu queria ficar lá até de noite. Estudar, comer, brincar um pouco, descansar, ir para quadra e...só, só sei isso.

Criança 1 - eu tenho uma amiga lá na rua que ela sai na hora que eu vou, eu chego da escola e ela está esperando o ônibus, depois ela chega de noite, daí eu queria ir de perua e queria ficar o dia inteiro na escola para aprender mais coisa porque lá na minha casa a gente brinca de escolinha.

Lara - Mas o que tinha que ter nesta escola?

Criança 1 - Eu acho que tinha que ter mais desenho..

Criança 3 - lousa...

Criança 1- E tinha que ter piscina também pra gente brincar.

Criança 3- Piscina de bolinha...

Lara - E você?

Criança 4- Um pula- pula.

Criança $1-\mathrm{E}$ um escorregador gigante.

Criança 3 - Eu queria ter um pula- pula e uma piscina de água.

Lara - E você?

Criança 2 - Um pula-pula.

Lara - Um pula-pula, você gostou da idéia?

Criança 2 - (afirma com a cabeça)

Lara - E vocês foram para outra escola antes desta daqui?

Criança 3- Eu fui para o Mathias.

Criança 1- Eu fui no prézinho perto da escola.

Lara - E você?

Criança 2 - Fui no prézinho.

Lara - Você também?

Criança 4 - (balança a cabeça afirmativamente) 
Lara -. E como era lá nestas duas escolas?

Criança 1 - Pra mim era tudo de bom...

Criança 4 - Era mais legal.

Lara - Era mais legal? Porque era mais legal?

Criança 4 - Porque lá tinha balanço e tinha aquela escada assim para subir. Escada de corda. Gira gira de pneu, tinha aquele negócio de pendurar.

Criança 2 - Eu também achava mais legal

Criança 3 - Tinha também túnel de pneu. Tinha uma professora legal, amigos legais. Eu queria ficar naquela escola.

Criança 1 - Óh, Lara quando eu estudava na escola perto da nossa o Rômulo sempre me batia quando tinha que cantar uma música.

Lara - Mas o que é que você fazia lá?

Criança 1 - Primeiro eu entrava, dava um beijo na minha mãe e eu ia para sala correndo e era meu pai quem me buscava co meu cachorrinho favorito, daí eu sabia que era o meu pai porque ele trazia meu cachorrinho.

Lara - O que você fazia nesta escola?

Criança 1 - A gente chegava pegava os material e fazia lição, pouca lição nós fazia, fazia desenhar igual aqueles desenhos ali (apontando para a parede)

Lara - Ah, de colagem.

Criança 1 - Ahnrã. Aí a gente saia, almoçava e depois ia para o parque brincar.

Lara - Vocês eram da mesma escola, os quatro?

Criança 3 - Eu era do Mathias.

Lara - Ah, eles três que eram da mesma escola? E vocês sabiam que antes as crianças da idade de vocês ficavam na escola das crianças pequenas, daí vieram os homens grandes e disseram que agora as crianças que tinham 6 anos iam ter de ir para a escola das crianças grandes. O que vocês acharam disso? Vocês preferem ficar nesta escola ou vocês acham que deveriam ficar na escola de antes?

Criança $1-\mathrm{Eu}$ queria ficar nessa aqui.

Criança 3 - Eu também.

Criança 4 - na outra.

Lara - Você queria na outra? Por quê?

Criança 4 - Porque tinha mais brinquedo.

Criança 3 - eu queria ficar aqui, porque aqui tem brinquedoteca e lá não tinha. Não, mais eu queria ficar um pouco naquela e um pouco nesta, porque lá também tinha uma ponte de 
madeira.

Criança 1 - E eu não gosto mais da ponte de madeira porque um dia eu ia segurar e eu cai e quebrei um dente, este aqui (apontando para o dente).Porque eu ia descer e doeu muito, daí eu puxei de volta a minha cabeça e eu desci de novo e falei com a prô.

Criança 3 - Lara, Lara. Sabia que eu tenho o DVD da outra escola e você sabia que sempre quando eu assisto eu choro?

Lara - Porque você chora?

Criança 3 - Porque eu sinto falta daquela escola.

Lara - E você, qual escola você prefere?

Criança 2 - Eu prefiro aqui.

Lara - Por quê?

Criança 2 - Porque eu gosto de ficar com os colegas grandes.

Criança 3 - Lara, eu preferia ficar na outra escola porque lá a gente achava aquelas moedinhas de chocolate.

Criança 1 - Isso não existe.

Lara - E você?

Criança 4 - Eu gostava de um brinquedo que balançava assim (faz com as mãos um movimento de vai e vem).

Lara - E as pessoas daquela escola?

Criança 1 - Ah, as professoras de lá são mais legais porque cantam as músicas eu era a última a terminar.

Criança 4 - E nesse brinquedo cabe mais ou menos umas 10 pessoas e daí a gente balançava assim (novamente imita o movimento).

Criança 3 - E também podia dormir na outra escola.

Criança 1 - Não podia nada. Eu não dormia, lá.

Criança 3 - Eu dormia. E todo mundo da minha sala dormia.

Lara - E vocês dormiam?

Criança 4 - Sim

Criança 2 - Sim.

Lara - E vocês gostavam?

Criança 4 - Eu gostava.

Criança 2 - Sim.

Criança 1 - Eu que não, já acordava mais cedo e não dormia.

Criança 4 - Às vezes tinha uma festa, lá. Tinha pula-pula. A gente também podia ir para a 
quadra.

Criança 3 - Eu odiava minha professora. Toda vez que ela falava alguma coisa, todo mundo dormia eu caia da cadeira.

Lara - Vocês querem falar mais alguma coisa para o Sebastião sobre esta escola?

Crianças (em coro) - Não.

Então vocês podem fazer mais uma coisa? Vocês já falaram bastante coisa e eu acho que ele vai ficar bem feliz.Vocês podem fazer um desenho de como é a escola de vocês para eu levar para ele ver?

Crianças (em coro) - Sim.

Lara - Vocês preferem aqui no chão ou nas mesinhas?

Crianças (em coro) - Na mesinha.

Criança 4 - Eu posso fazer a outra escola?

Lara - Pode, mas você precisa fazer esta também.

Criança 1 - Eu posso fazer o parquinho?

Lara - Você pode fazer o que você quiser. O que você vai desenhar?

Criança 2 - A quadra da escola.

Criança 1 - Eu vou desenhar o parquinho.

Criança 3 - A quadra.

Criança 4 - Eu vou desenhar a escola.

(continua no desenvolvimento do desenho para o Sebastião, A gravação é encerrada.)

\section{Entrevista com crianças - grupo 2}

Meu nome é Lara, eu tenho 24 anos. Quantos anos vocês tem?

Criança 5 - tenho 7 anos.

Criança 6 - tenho 7 anos.

Criança 7 - tenho 7 anos.

Criança $8-7$ anos.

Criança 9 - Eu também, mas ninguém acredita.

Criança 10 - tenho 6 anos.

Lara - Eu tenho um amigo que mora um pouquinho longe daqui de São Bernardo e ele nunca foi para a escola e agora a mãe dele vai morar em São Paulo e vai colocar ele na escola ele 
tem 6 anos, igual vocês tinham quando entraram na escola. Daí eu preciso de crianças que contem para ele como é a escola onde vocês estudam. Vocês podem me ajudar a contar para ele como é a escola de vocês?

Crianças (em coro) - Podemos.

Lara - Vocês podem começar falando. O que vocês fazem aqui na escola?

Criança 7 - Nós brinca e...

Criança 5 - Faz bastante lição. Pinta, vai para o almoço...

Criança 7 - Depois vai para o parque.

Criança 8 - Nós continua depois fazendo lição.

Criança 5 - Ajuda a professora.

Criança 8 - E no final da aula a gente pode brincar um pouco.

Criança 10 - Depois a gente vai para o curso.

Criança 5 - Tem gente que depois vai para o ballet.

Lara - Vocês brincam do que e fazem lição do que?

Criança 9 - Nós fazemos um calendário do Natal, assim (mostra um formato quadrado com as mãos).

Criança 8 - Faz apostila dos animais do mar.

Criança 7- A gente faz continha.

Lara - E o que vocês gostam mais de fazer na escola?

Crianças (em coro) - Brincar.

Lara - E você Victor do que você mais gosta de fazer na escola?

Criança 5 - Eu gosto mais de desenhar.

Criança 9 - Eu também, eu sou desenhista.

Criança 10 - Eu também.

Criança 8 - Eu gosto mais de desenhar carro do jeito que eu sei.

Criança 6 - Eu e a Aline gostamos só de brincar.

Lara - Vocês brincam bastante na escola?

Criança 7 - Sim, mas não tem muito brinquedo.

Lara - Você queria que tivesse mais brinquedo?

Criança 6 - Mas na brinquedoteca tem um monte (apontando para a colega).

Criança 7 - É e na sala dos inspetores tem um monte.

Lara - Vocês gostam de ir na brinquedoteca?

Crianças (em coro) - Sim.

Lara - E do que vocês não gostam? 
Crianças 6 e 7 (respondem juntas) - Lição...

Criança 5 - Eu gosto de fazer lição, só não gosto de escrever muita coisa que a "prô" passa.

Criança 8 - Eu também, mas eu não gosto de matemática. Eu gosto de escrever.

Criança 10 - Eu também não gosto. Porque é chato.

Criança 9 - Eu não gosto mais ou menos de matemática.

Lara - E se vocês pudessem mudar alguma coisa aqui na escola o que vocês mudariam?

Criança 7 - A lição.

Lara - Você mudaria como?

Criança 7 - (risos) Eu colocaria toda hora brincar.

Criança 6 - Colocaria brinquedo na sala toda.

Criança 10 - Só desenho.

Criança 6 - Não. Desenho e ter um monte de presente.

Lara - Vocês acham que crianças de 6 anos como o Sebastião devem ir para a escola?

Crianças (em coro) - Sim.

Lara - Por quê?

Criança 5 - Porque se elas não irem para escola quando elas crescerem vão ficar sem aprender.

Criança 7 - Elas têm que aprender e passar de ano.

Criança 9 - Para aprender a ler e a escrever.

Criança 8 -E também para ficar esperto na escola.

Criança 5 - Para aprender a fazer as coisas direito.

Criança 10 - e também para ficar com a cabeça bem grandona.

Lara - O que vocês acham que é uma escola boa para crianças da idade de vocês, que nem o

Sebastião que vai entrar na escola agora?

Criança 7 - Cheia de brinquedo, que não tem lição.

Criança 10 - Só de desenho. Só presente.

Criança 6 - Boneca, Barbie, Poly.

Criança 8 - Carrinho de controle remoto.

Criança 10 - Queria viajar.

Lara-Que na escola tivesse viagem?

Criança 10 - Sim.

Lara - E antes de vocês estudarem aqui vocês estudaram em outra escola?

Criança 5 - Estudava no prezinho em outra escola e vim para esta.

Criança 6 - Eu estava estudando, mas era nesta escola. 
Criança 7 - Eu estava em outra escola, depois vim para esta e mudei de sala, para sala da professora que eu estou agora.

Criança 8 - Eu estudava numa escola aqui do lado, depois eu fiz 6 anos e minha mãe mudou eu para cá.

Criança 9 - Eu estudava no prezinho e também quando fiz 6 anos vim para cá.

Criança 10 - Eu também, estudava no prezinho e depois vim para cá.

Lara - E o que vocês faziam na escola que vocês estudavam antes?

Criança 7 - Fazia lição, tinha café da manhã.

Criança 6 - Tinha brinquedos o maior legal. Mas tinha um monte de brinquedo que não era igual aos que tem aqui. Lá tinha balança, escorregador, tinha balança de pneu.

Criança 9 - Tinha muita areia.

Criança 10 - Tinha casinha.

Criança 6 - Tinha casinha com escorregador.

Lara - Quem era da mesma escola?

(As crianças levantam a mão. As crianças 6 e 7 eram de uma e as demais de outra)

Lara - Se vocês pudessem escolher entre a escola que vocês estudavam e esta, em qual vocês gostariam de estudar?

Crianças 5, 6, 7, 8 e 9 (em coro) - Nessa daqui.

Criança 10 - Naquela outra.

Lara - Porque naquela outra?

Criança 10 - Porque aquela outra era legal, as brincadeiras de crianças era mais legal e a prô também era mais legal. Tinha duas prô.

Criança 7 - E queria estudar de manhã aqui e de tarde lá. Mas a minha mãe não deixa.

Lara - Vocês sabiam que antes as crianças de 6 anos continuavam estudando naquela escola até terem 7 anos. Aí com 7 anos elas vinham para esta escola. Daí vieram os adultos, os homens grandes e fizeram uma lei, assinaram um papel para as crianças de 6 anos estudarem nesta escola aqui. O que vocês acham disso?

Criança 6 - É legal.

Crianças 9 e 10 (respondem juntas) - É chato.

Lara - Por quê?

Criança 6 -É legal.

Lara - Porque você acha legal?

Criança 6 - Porque elas tem que aprender algumas coisas aqui.

Criança 10 - Porque eu não acho legal ficar aqui eu preferia ficar lá. 
Criança 8- Eu gosto mais desta escola porque aqui nós aprendemos mais coisa.

Criança 9 - Porque aqui eu posso aprender melhor a ler, a escrever e a fazer mais lição.

Criança 6 - Eu também acho a mesma coisa.

Lara - Eu posso pedir um último favor? Que vocês façam um desenho da escola de vocês para

o Sebastião ver? Pode ser?

Crianças (em coro) - Sim.

(continua no desenvolvimento do desenho para o Sebastião, A gravação é encerrada.)

\section{Entrevista com crianças - grupo 3}

Sandra - Meu nome é Sandra. Quantos anos vocês tem?

Criança 11 - eu tenho 7 anos.

Criança 12 - eu tenho 7 anos.

Criança 13 - E eu também 7 anos.

Criança $14-7$ anos.

Criança 15 - eu tenho 6 anos.

Criança 11 - Quando eu era do tamanho dela eu tinha 6.

Sandra - E você?

Criança 16 - tenho 7 anos.

Sandra - Qual é o nome da escola que vocês estudam?

Crianças (em coro) - EMEB (nome da escola).

Eu tenho um amigo que mora um pouquinho longe daqui de São Bernardo e ele nunca foi para a escola e agora a mãe dele vai morar em São Paulo e vai colocar ele na escola ele tem 6 anos, igual vocês tinham quando entraram na escola. Daí eu preciso de crianças que contem para ele como é a escola onde vocês estudam. Vocês podem me ajudar a contar para ele como é a escola de vocês? Para ver se ele fica menos nervoso.

Criança 11 - A escola é muito legal, a gente brinca, a gente tem que ouvir a professora e não tem que responder.

Criança 15 - A gente joga futebol.

Criança 16 - E também a professora explica para gente.

Sandra - Agora falem para mim quais são as melhores coisas que existem na escola?

Criança 14 - Estudar.

Criança 13 - Jogar futebol. 
Criança 12 - Estudar.

Criança 15 - Jogar futebol.

Criança 16 - Jogar futebol.

Criança 11- Eu gosto de...aprender. Aprender a ler.

Sandra - E vocês aprendem a ler nesta escola?

Crianças (em coro) - Sim

Sandra - Quem já aprendeu a ler aqui?

(Crianças levantam as mãos).

Sandra - E as coisas que vocês não gostam na escola?

Criança 16 - Eu não gosto de parar de estudar.

Criança 15 - Eu não gosto de pular corda.

Criança 11 - Eu não gosto de ficar brigando com ele.

Criança 12 - Pular corda. Eu odeio.

Criança 14 - A única coisa que eu não gosto na escola é de ficar correndo.

Criança 13 - Lição.

Sandra - Lição? Você não gosta de fazer lição?

Criança 13 - Se for para fazer lição eu faço rápido.

Sandra - O Sebastião queria saber, se vocês tivessem que mudar alguma coisa nesta escola o que vocês mudariam?

Criança 14 - Eu gostaria de mudar os brinquedos porque tem poucos brinquedos na escola.

Criança 16 - Eu quero mudar para estudar na escola de São Paulo.

Sandra - Mas o que tem na escola de São Paulo que você quer mudar para lá?

Criança 16 - Lá tem piscina de bolinha.

Criança 11 - Eu queria mudar para a outra escola que eu estudava porque lá tinha polícia, tinha corda, tinha pula-pula, tinha piscina de bolinhas, de água, tinha também um montão de bexigas também, eles davam chocolate, eles davam cachorro-quente também. Tinha uma tia que fazia a gente fazer um montão de lição e quando a gente ficava na quadra a professora deixava a gente desenhar e fazer um montão de coisas lá.

Sandra - Olha só, vocês já estudaram numa escola diferente dessa? A Fabiana disse que já estudou e vocês?

Criança 11 - Ah e depois da escola eu ia para casa me arrumar e depois voltava lá tinha um montão de brinquedo, tinha aqueles tapetes que gruda podia fazer casinha, pegava cadeiras e podia fazer um montão de coisas.

Sandra - E você Nicássia, se você tivesse que escolher você preferia estudar aqui ou lá? 
Criança 14 - Aqui. Porque aqui tem um monte de coisa para ver e para fazer. Lá só tinha desenho.

Criança 11 - Eu queria que tivesse piscina de bolinha, computador, laptop, um monte de coisa...

Sandra - se vocês tivessem que fazer uma escola para criança pequena assim do tamanho de vocês o que teria de ter nesta escola?

Criança 16 - Eu acharia que tinha que ter educação.

Criança 14 - Professores para que as crianças possam ler bem rápido.

Criança 13 - Com lição que não seja tão difícil.

Criança 12 - Uma quadra de futebol e uma professora muito legal e um parquinho grandão. E um vídeo-game.

Criança 11 - Ter brinquedos novos e ter uma professora muito, muito, muito e muito legal que deixasse a gente só brincar mesmo, depois que acabasse a aula de brincar a gente fizesse só um pouquinho de lição e a gente ia embora.

Sandra - Vocês sabiam que até pouco tempo atrás crianças da idade de vocês estudavam em escolas menores e que crianças maiores estudavam em outra escola. Daí vieram os homens grandes e assinaram um papel dizendo que agora as crianças da idade de vocês estudariam na escola com as crianças grandes. O que vocês acham desta idéia?

Criança 16 - Não, não, não, porque eles batem na gente.

Criança 11 - E também teve aquele dia que o menino grande foi lá e me bateu aí as meninas me ajudou. Porque eu estava indo no banheiro. Eu prefiro estudar em escola que é de gente pequena.

Criança 14 - Para a Bianca tem que ser pequena para a gente que é maior tem que ser grande.

Criança 11 - Criança grande bate, fica mostrando o dedo, fica falando das professoras por detrás, fica xingando o amigo, fica xingando a gente então...

Sandra - Agora eu gostaria de saber se vocês podem fazer um desenho da escola de vocês para que eu possa levar para o Sebastião. Pode ser?

Crianças (em coro) - Sim.

\section{Entrevista com crianças - grupo 4}

Sandra - Oi, eu sou a Sandra e queria saber quantos anos vocês tem.

Criança 17 - tenho 7 anos.

Criança 18 - tenho 7 anos. 
Criança 19 - tenho 6.

Criança 20 - 7 anos.

Sandra - Eu tenho um amigo que mora um pouquinho longe daqui de São Bernardo e ele nunca foi para a escola e agora a mãe dele vai morar em São Paulo e vai colocar ele na escola ele tem 6 anos, igual vocês tinham quando entraram na escola. Daí eu preciso de crianças que contem para ele como é a escola onde vocês estudam. Vocês podem me ajudar a contar para ele como é a escola de vocês? Para ver se ele fica menos nervoso.

Criança 17 - Eu gosto da escola.

Criança 20- Eu gosto da escola.

Criança 18 - Eu não.

Sandra - E o que você mais gosta na escola?

Criança 18 - Eu não gosto de fazer lição.

Criança 17 - Eu gosto de fazer lição, para mim aprender a ler e escrever.

Criança 20 - Eu gosto de fazer lição para aprender a ler.

Criança 18 - Eu só gosto de ler.

Sandra - Do que você não gosta que você falou?

Criança 18 - De fazer lição difícil, cruzadinha.

Criança 17 - Eu gosto de fazer continha de mais.

Sandra - E o que vocês acham que tem de legal nesta escola?

Criança 19 - Brincar de pega-pega.

Criança 17 - Eu gosto de aprender.

Criança 20 - Duro ou mole.

Criança 18 - Eu gosto de ficar o dia inteiro na balança.

Criança 17 - Eu também gosto de brincar na balança, no gira-gira.

Criança 20 - Eu também.

Sandra - E o que vocês acham mais legal?

Criança 20 - Lição.

Criança 19 - Da brinquedoteca de brinquedo.

Criança 18 - Informática. Eu gosto de ver livros na biblioteca.

Criança 19 - Daquele balanço lá.

Criança 17 - Eu gosto de mexer no computador.

Criança 19 - Eu também, chego em casa e vou direto para o computador.

Sandra - Vocês falaram várias coisas de que vocês gostam na escola. Agora eu quero saber as coisas de que vocês não gostam? 
Criança 19 - Eu não gosto de fazer lição.

Criança 20 - Dos meninos que ficam batendo em mim.

Criança 18 - Eu gosto de mexer com os outros e sair correndo. Eu não gosto quando eles me batem.

Sandra - Se vocês tivessem que mudar alguma coisa nesta escola, o que vocês mudariam?

Criança 17 - Eu fazia as regras para não ficar bagunçando.

Criança 20 - eu faria alguma coisa para as crianças não se baterem.

Sandra - E você?

Criança 18 - Eu não pensei em nada ainda.

Criança 19 - Eu também não.

Sandra - Mas, o que vocês mudariam?

Criança 18 - Eu mudaria tudo.

Sandra - Vocês já estudaram em outra escola, antes desta? Onde era melhor aqui ou lá?

Criança 19 - Lá.

Criança 17 - Eu acho lá, aqui da muita lição. Mas agora eu prefiro ficar aqui porque eu estou aprendendo a ler. Antes eu gostava de ficar na creche.

Criança 20 - Eu também.

Sandra - Por quê?

Criança 20 - Porque eu gostava de fazer bagunça.

(As crianças dão risada)

Sandra - E aqui não pode fazer bagunça?

Criança 18 - Aqui não pode, porque se não vai para diretoria.

Sandra - E lá não ia? Ia para onde.

Criança 18 - A professora levava a gente para o parque.

Criança 17 - Lá tinha brinquedos, a gente podia fazer bagunça.

Sandra - Se vocês tivessem que pensar numa escola para crianças da idade de vocês, como seria esta escola? O que deveria ter nesta escola para ser legal?

Criancas 18 e 20 - Mais brinquedo.

Criança 17 - Eu gostaria de poder fazer bagunça.

Sandra - Um lugar onde pudesse fazer bagunça?

Crianças 17,18 e 20 - É.

Sandra - E você?

Criança 19 - Cheia de brinquedo. 
Sandra - Vocês sabiam que foram os homens grandes que decidiram que vocês precisavam vir para esta escola?

Criança 18 - A minha prima tinha que ir para o prezinho e ao invés dela passar por uma sala igual a esta ela veio direto para a primeira série.

Sandra - E vocês acham isso legal?

Criança 18 - Não, ela tinha que passar pelo prezinho primeiro.

Sandra - Porque você acha que ela deveria passar pelo prezinho primeiro?

Criança 18 - Porque ela já ia sair do prezinho já muito esperta.

Sandra - Agora eu gostaria de saber se vocês podem fazer um desenho da escola de vocês para que eu possa levar para o Sebastião. Pode ser?

Crianças (em coro) - Pode!

\section{Entrevistada com a professora representante do Conselho de Escola}

Lara - Qual seguimento que você representa?

Professora - O Conselho de escola

Lara - Mas representa os professores do conselho?

Professora - Agora não lembro...mas acho que...

Lara - - Há quanto tempo você é representante?

Professora - Entrei esse ano.

Lara - Você ficou sabendo que o ensino fundamental passou a ter nove anos de duração que as crianças entrariam com seis anos?Lembra?

Professora - Desde o ano passado.

Lara - Você ficou sabendo aqui na escola?

Professora - Não. Na outra escola que eu trabalhava.

Lara - E o ensino fundamental de 9 anos foi discutido no conselho de escola?

Docente representante do Conselho de Escola - Várias vezes.

Lara - Como foram às discursões?

Professora - É...na realidade, teve coisas que a gente assim... gostou e não gostou. Esse negócio de ciclo pra gente não funciona. É...esse negócio de ciclo para muitos professores isso é furada. Aprovar uma criança que você ver que não tem condições, na dá. Teve muitas discussões principalmente com a primeira série com adequação da sala. Que nem igual: a criança vem com a faixa etária menor e aí já querem fazer a mesma coisa que o ensino de oito anos, só que a sala não ta separada e a criança ta numa faixa etária diferente. Então eu acho 
que a gente bateu muito, discutiu muito na questão do material e adequação da sala. E não só da sala, os conteúdos também porque a cabecinha deles gente dá dó. Então foi isso.

Lara - A discussão foi feita com bastante gente da comunidade escolar, como é que foi essa discussão com os funcionários, os pais?

Professora - Aqui nessa escola deixa eu ver...do conselho, lembro que tinha...acho que era quatro mães; na outra escola tinha mais, na outra escola que eu tava lá que eu participei, tinha mais. Sempre tem.

Lara - São Bernardo também?

Professora - São Bernardo também. Mas sempre tem alguém, as mães das comunidade é uma e outra que vem. Aqui se não me engano, no dia que eu participei do conselho tinha que acho umas quatro mães,

Lara - E qual a sua opinião sobre o ensino fundamental de nove anos, você concorda que as crianças da educação infantil comecem mais cedo o fundamental?

Professora - Eu sou que nem minhas colegas, no mínimo eu tiraria esse negócio de.ano ciclo voltaria o que era antes, eu não sou a favor do ano/ciclo.

Lara - Mas as crianças de seis anos deveriam ficar mais um ano na educação infantil?

Professora - Deveria.

Lara - Você gostava mais como era antes?

Professora - Sim

Lara - Por quê? Você acha que era melhor?

Professora - Por causa da... como é que fala... é a faixa etária; gente, é a infância. Que nem quando vai do infantil vem para a primeira série tem uma queda porque o trabalho que é feito no infantil, quando chega na primeira série a cobrança de conteúdo é maior, não que no infantil não tenha, tem, mas no fundamental, sei lá parece que quebra alguma coisa né? Dá dó de ver esses pequenininhos assim. Por isso que a gente fala: precisa de uma adequação curricular da sala de aula, porque é judiar das crianças.

Lara - Que providência você lembra que o conselho de escola tirou para serem feitos para adequar o espaço físico e os conteúdos na escola?

Professora - Olha, sei que a gente falou muito. Só que a gente...oh, aqui eu lembro que a gente comentou mais isso aí é...mas isso eu não lembro se foi na reunião de conselho, ou se foi o conselho e a APM. É assim, veio esse negócio de nove anos, mas não veio material nenhum. Aí foi até uma professora daqui, também trabalhava na prefeitura de SP e lá eles já tem o material em termos de conteúdo porque aqui em São Bernardo não tem. E eles colocaram e a proposta em termos de conteúdo, material pedagógico é...como é que fala...[Lara - as 
orientações curriculares?] isso, por enquanto não tem. Ela teve que trazer da prefeitura de SP para as colegas poderem trabalharem aqui, foi que elas conseguiram trabalhar em cima. Então a primeira coisa que a gente pensou foi isso. Oh, bem, a sala não estão adequadas e o que a gente vai dá para essas crianças? Porque se é com cara de primeira série, não pode ser assim tão infantilizada como é que fica?Então essa colega trouxe esse material da prefeitura e elas trabalharam em cima disso. Em termos de atitude, acho que o primeiro passo foi esse: o que fazer com as crianças dentro do que a gente tem. Em termos de sala parece que ... Eu não sei bem da sala dela, mas elas conseguiram trocar as mesas [Lara - isso é mesinha quadrada] e em termos de conteúdo foi o que a colega trouxe o material de SP.

Lara - E você acha que a opinião dos professores sobre o ensino fundamental de nove anos você acha que eles concordam com essa mudança?

Professora - Tem gente que concorda, tem gente que é a favor do antigo, tem gente que tanto faz porque não trabalha com este.

Lara - Existe um acompanhamento do conselho de escola sobre o ensino fundamental de nove anos, vem discutindo para avaliar como foi a implantação, que medidas vão ser tomadas?

Professora - Desta reunião eu participei de uma só. Mas pelo o que eu vejo elas conversaram sim. Porque a diretora, ela marca as coisas, certo?Ela fala: precisa disso. Mesmo porque tem umas professoras que vai conversar com a coordenadora e elas passam, aí na reunião é passado para ver o que o conselho está decidindo. Se não me engano, tinham duas mães acho que elas estavam com as crianças na reunião, elas fazem parte dessas crianças de nove anos.

\section{Entrevista com as funcionárias representantes do Conselho de Escola}

Lara - Qual o seguimento que vocês representam?

Funcionária 1 - Eu trabalho na limpeza.

Funcionária 2 - Eu também.

Lara - Há quanto tempo vocês são representantes?

Funcionária 1 - Um ano.

Funcionária 2 - Já faz um ano e poucos meses.

Lara -Vocês sabem que agora o ensino fundamental terão nove anos de duração e que foi aprovada uma lei que as crianças vão entrar no ensino fundamental tendo seis anos de idade?

Funcionária 1 - Eu sei.

Funcionária 2 - Eu sei.

Lara -Como vocês ficaram sabendo? 
Funcionária 1 - Fiquei sabendo aqui pela escola.

Funcionária 2 - Eu também.

Lara - Os filhos de vocês estão em que série na escola?

Funcionária 1- A minha está no infantil.

Funcionária 2 - A minha na quarta série.

Lara - Vocês lembram se o ensino fundamental de nove anos foi discutido no conselho de escola?

Funcionária 1 - Foi. Disseram que existe uma lei e que SBC é o único município que ainda não entrou e que em outros países isso já existe.

Lara - Sobre a legislação?

Funcionária 1 - Isso.

Lara - Como que foi essa discussão? Trataram sobre o primeiro ano, o que iria mudar na rotina?

Funcionária 2 - Não me lembro.

Funcionária 1 - Falou. Foi naquela reunião que a gente veio às 7 h00 da noite aqui.

Funcionária 2 - Comigo não foi discutido, não. Foi falado rápido apenas para deixar os pais cientes.

Lara - Não foi discutido, por exemplo, questões para melhoria no atendimento das crianças desta faixa etária como precisamos ter uma brinquedoteca?

Funcionária 2 - Isso não porque na escola sempre teve brinquedoteca, a conversa sobre isso foi mais um comunicado.

Lara - Qual a opinião de vocês sobre a ampliação do ensino fundamental? Vocês acham melhor ou vocês preferem que elas fiquem no infantil?

Funcionária 1 - Eu acho bom, só acho que devia ser melhor adaptado, carteira, mesa.

Funcionária 2 - De acordo com a escola, com a idade. Isso. Para o tamanho deles. Como bebedouro.

Lara - Vocês não sabem quais providências foram discutidas no conselho de escola para a entrada dessas crianças?

Funcionária 1 - Eles meio que jogaram. Eles falaram que vai ter que chegar e fica

Funcionária $2-$ É, foi bem assim.

Lara - Ninguém falou sobre a possibilidade de recorrer?

Funcionária 1 - Não, porque do jeito que veio não havia mais para onde recorrer, porque SBC era o último município, então tinha que entrar no esquema. 
Lara - Existe um acompanhamento do Conselho de Escola sobre a implantação? Discutiram em algum momento posterior como está sendo?

Funcionária 1 - Não.

Funcionária 2 - Só na APM, discutiu sobre alguns móveis, equipamentos, brinquedos.

Lara - Sobre compra de materiais?

Funcionária 1 - Isso.

Funcionária 2 - Isso.

\section{Entrevista com a Secretária de Educação}

Lara - Quanto tempo você está no cargo?

Secretária da Educação - Desde 2009, desde o primeiro dia dessa nova gestão.

Lara - E qual é a sua formação?

Secretária da Educação - Pedagogia, não primeiro magistério. Vamos começar com a educação. Primeiro magistério, quando ainda era normal, de 4 anos. Pedagogia em administração escolar e orientação educacional, depois pós-graduação em didática do ensino superior e mestrado na área de educação de jovens e adultos. Toda trajetória na educação Lara - Você trabalhou como professora?

Secretária da Educação - Fui professora de educação infantil, professora alfabetizadora por muitos anos, é um das áreas que eu mais gosto. Só não dei aula de $5^{\mathrm{a}}$ à $8^{\mathrm{a}}$ série, mas fui professora de magistério, para turmas de magistério, professora universitária e professora de pós-graduação.

Lara - Aqui em SBC ou em SP?

Secretária da Educação - Em SP.

Lara - Você poderia nos contar como foi o processo de implantação do ensino fundamental de nove anos aqui em SBC?

Secretária da Educação - Infelizmente, o processo de implantação não foi como deveria ter sido. Eu fui secretária de educação de santo André por sete anos e lá já em 2005 quando da legislação que estava em tramitação nós já começamos com o ensino fundamental de nove anos porque nós não tínhamos rede municipalizada. Em Santo André era rede própria de ensino fundamental, então ficou bem mais tranquilo. Quando nós assumimos aqui em 2009 foi que eu soube que esta foi a única secretaria de todas as outras que não houve transição, eu não recebi nenhuma documentação, nenhum arquivo onde eu tinha dados sobre, para vocês terem uma ideia, a empresa que cuidava dos dados da educação tinha vencido o contrato, este 
não tinha sido renovado, portanto eu cheguei aqui e não sabia nem o número de alunos. Nós usamos, como eu tinha trabalhado no ministério da educação, no ano de 2008 , no ano inteiro lá em Brasília, eu liguei para o INEP. Conseguimos os nossos dados e a partir daí já fazendo um diagnóstico da rede que era fundamental, porque nós temos um plano de governo, um programa de governo que foi aprovado pela população e teríamos que implantá-lo e uma das questões era a implantação do ensino fundamental de nove anos e o último ano de implantação era 2010. Nós assumimos em 2009 então teríamos que fazer a implantação em 7 meses. O que significou isso? Conversar com os professores, conversar com as famílias, reorganizar as escolas para receber os alunos do fundamental, neste caso do primeiro ano do ciclo de nove ou algumas escolas não tinham espaço e, portanto, as crianças ficaram na préescola, mas já com o nome de primeiro ano do fundamental de nove anos e vamos conviver ao longo dos oito anos com as duas formas fundamental de oito e de nove, porque como começamos em 2010, só terminará em 2018. Não 2018 porque aqui é só do primeiro ao quinto ano, porque aqui é por ciclos, então vamos conviver por cinco anos até que todos estejam no fundamental de nove anos, enquanto Santo André todos já estão no fundamental de nove anos.

Lara - Como foram as reuniões realizadas com os professores e com as escolas?

Secretária da Educação - Primeiro nós fizemos todo um levantamento de legislação para que os professores pudessem entender o porquê desta mudança. O MEC tinha lançado um caderno até de orientações para implantação e porque foi dado este prazo, justamente para que ela fosse feita de uma forma gradativa e nós tivemos que fazer isso de modo muito mais acelerado isso é muito mais complexo. Você tinha diretoras que são muito mais resistentes que outras e a gente queria que também a família entendesse este processo. Porque a gente tinha dois amigos onde um deles, no entendimento deles, iria passar de ano e o outro não, então para nós explicarmos qual era a diferença e, eu acho que o momento mais difícil foi a conversa com as famílias para explicação de que as crianças não seriam atrasadas ou adiantadas que elas estariam em seu ciclo de acordo com a nova legislação, com a nova organização do sistema. Esta foi a parte mais difícil, mas sempre em reuniões pequenas para que as pessoas pudessem falar, pudessem perguntar, tirar todas as dúvidas, enfim, para esclarecer e os pais saírem sossegados. Que era nossa preocupação maior, porque com os professores foi um pouco mais tranqüilo, o entendimento deles foi melhor até porque eles estavam estranhando que as outras redes haviam mudado e aqui ainda não. Então não foi tão complexo assim. Com os pais foi o entendimento deles de que as crianças não seriam prejudicadas, que é a preocupação de qualquer pai e mãe. 
Lara - Você disse que algumas crianças ficaram na pré-escola com o nome de primeiro ano e outros foram de fato para o fundamental de nove anos, e como foi definida a idade de corte? Secretária da Educação - Nós seguimos a primeira resolução do Conselho Nacional de Educação que era o último dia do mês de fevereiro, que às vezes coincide com o primeiro dia do ano letivo ou não, Então o corte nos fizemos em $1^{\circ}$ de março. As crianças que faziam 6 anos até o dia $1^{\circ}$ de março iriam para o primeiro ano do ensino fundamental de nove anos, já as crianças que faziam 6 anos depois disso, ficariam na pré-escola, mas aí já numa outra organização para que eles não repetissem os mesmos conteúdos, a mesma forma de trabalho, enfim toda uma reorganização da rede porque esta seria uma primeira turma e a gente também já fez esta mudança para baixo, este corte já foi feito desde à pré-escola. As crianças que fariam 4 anos até $1^{\circ}$ de março iam para a pré-escola, as que não ficaram na creche.

Lara - E para a $1^{\mathrm{a}}$ série de 8 anos iriam as crianças que fariam 7 anos até $1^{\circ}$ de março?

Secretária da Educação - Isso porque ainda tínhamos este grupo que segue o fundamental de 8 anos.

Lara - Você considera que esta nova organização esta sendo mais interessante para o processo pedagógico das crianças?

Secretária da Educação - Na verdade, eu sou da linha de que a gente deveria trabalhar com a primeira infância, de 0 a dez anos, por isso eu sou a favor da municipalização de primeira á quarta ou agora do primeiro ao quinto ano. Por quê? No meu entendimento e na teoria que eu acredito, é uma fase que ela tem as suas divisões, ma sé onde a criança é mais criança. Porque esta ruptura da pré-escola para o fundamental é muito drástica e aqui em SBC isso é muito evidenciado. As escolas de ensino fundamental não têm parque, não tem espaço para as crianças brincarem como na pré- escola. Eu entendo diferente, que as crianças fazem 7 anos, mas elas gostam de escorregador, de balançar, de brincar na areia, ter os seus espaços. Brincar é necessário até... na adolescência a gente gosta de brincar, só muda o tipo da brincadeira.

Caroline - Então você acha que tem diminuído esta ruptura com o fundamental de nove anos? Secretária da Educação - Isso fez com que a nossa rede fizesse uma reflexão também sobre as crianças de 7 anos. De 7, de 8 e de 9, com a entrada destas crianças de 6 nas escolas de ensino fundamental nós conseguimos sensibilizar mais a importância do direito da criança brincar. Os espaços de brincadeira, os espaços que parecem que não são educativos e que na verdade educam muito mais e que fazem parte da construção do que eles serão, inclusive daqueles que serão líderes, daqueles que tem mais tendências para leitura, mais para cálculo ou alguma coisa assim. Então é nas brincadeiras que a gente consegue diagnosticar também algumas questões, se há problemas de violência doméstica, se você na brincadeira uma mãe 
que põe todo mundo de castigo ou que apanha. Ou as crianças imitam muito os professores na hora do recreio, como é que se lida com isso em sala de aula. Eu acho que o brincar é muito importante, dá tanto elemento para a gente fazer planejamento.

Lara - De modo mais geral você acha que a rede como um todo estava preparada para receber estas crianças para o ensino fundamental de nove anos?

Secretária da Educação - Não, porque, por isso mesmo que a lei permitia este espaço, porque era uma questão gradativa. Um agravante é que tínhamos uma rede própria de educação infantil que foi unida á outra com a municipalização, nisso temos professores que vem de dois vínculos de trabalho distintos e de duas formas de trabalho muito distintas que é a rede municipal e a rede estadual e até hoje temos conflitos que são sempre administrados, são poucos agora, mas que existe, existe. Parece que a rede de SBC de educação infantil, inclusive quando eu entrei uma das coisas que mais me chamou atenção era a maneira como as pessoas se apresentavam: - Eu sou professora da rede de SBC. Outra: - Eu sou professora da rede municipalizada de SBC. E agora para mim chega: - Eu sou professora da rede de SBC. Eu não sou da rede municipalizada.

Caroline - Era uma resistência?

Secretária da Educação - Isso mesmo. Principalmente, não das que vieram da municipalização porque para elas é vantajoso financeiramente, porque o salário do município é maior do que do estado e a gente complementa para que elas recebam a mesma coisa. Mas a resistência foi da rede de educação infantil porque ela é histórica no $\mathrm{ABC}$ todo. $\mathrm{O} \mathrm{ABC}$ tem uma história de educação infantil muito rica. Todos os grandes seminários de educação infantil eram feitos aqui no ABC. Eu mesma, aos dezoito, dezenove anos fazer aqui no Vera Cruz, Vera Cruz era onde se faziam os filmes, aquele estúdio de cinema antigo, eu vinha fazer formação de Educação Infantil porque era notória a qualidade do atendimento da Educação Infantil na região do $\mathrm{ABC}$, em SBC, Santo André e São Caetano que eram as cidades mais ricas na época. Você tinha uma história de rede de uns 50,60 anos e municipalizar a entrada de uma nova estrutura, uma nova cultura é bem diferente e choca, não tem como isso em qualquer lugar.

Lara - Quais mudanças foram feitas na rede para receber estas crianças?

Secretária da Educação - Adaptações físicas, formação dos professores, formação para coordenadores, principalmente a criação de vínculos maiores entre a pré escola e fundamental. Aquela coisa de visitas às escolas, de que as crianças passassem o dia numa sala de fundamental isso era muito importante, esta integração

Caroline - Mas, isso chegou a acontecer mesmo no projeto 
Secretária da Educação - Aconteceu, projeto mesmo, por organização pedagógica com as orientadoras para que as crianças fossem visitar as escolas, que os professores do fundamental fossem visitar as escolas de educação infantil, essa integração, não só interação, mas integração foi muito importante para deixarmos de ser duas redes e se transformar numa rede só.

Lara - E adaptações físicas, quais foram feitas?

Secretária da Educação - Ajustes em banheiros ou em alguns locais, algumas escolas criaram brinquedotecas, espaços para parque e mobiliário. Porque o mobiliário do fundamental geralmente é maior e as coisas mais coloridas de mesas, de grupos de mesas, de outra organização escolar está entrando no fundamental e, é engraçado que contamina porque eu hoje vou às escolas e vejo disposições distintas daquele enfileiramento nas escolas Lara - Foram oferecidas formações para os professores?

Secretária da Educação - inicialmente aos professores que assumiriam estas turmas teriam formação específica já na linha de quais seriam os conteúdos que seriam desenvolvidos na qualidade e não na quantidade que eu gostaria porque nós tínhamos pouco tempo, mas para que eles não assumissem simplesmente as turmas e, em algumas escolas foram feitas até trocas de professores, onde alguns alunos da educação infantil perderam professores para o ensino fundamental. Isso aconteceu.

Caroline - Esta formação continua acontecendo?

Secretária da Educação - Continua, principalmente o acompanhamento. Para sabermos, este ano por exemplo é ano de Prova Brasil, estas crianças vão passar pela primeira vez por esta prova, assim como outras, mas para estas será uma experiência em crianças muito mais novas. Neste sentido, o acompanhamento das professoras de primeiro ano é muito mais próximo dos que das outras turmas.

Lara - Onde aconteceram as formações? Nas escolas ou os professores vieram até aqui?

Secretária da Educação - Não nós temos um centro de formação (CENFOR) e muita orientação na sala de aula, da coordenação pedagógica na sala de aula, do acompanhamento da recepção dos professores pelo coordenador. (16’42)

Lara - Quais os planos da rede para continuar esta implementação?

Secretária da Educação - Agora nós já entramos no que a gente chama de rotina aí já é o segundo ano da implantação as coisa aconteceram de forma muito tranqüila e o ciclo tem, são dois ciclos, o do ensino fundamental o de três anos $\left(1^{\circ}, 2^{\circ}\right.$ e $\left.3^{\circ}\right)$ e um de dois anos $\left(4^{\circ}\right.$ e $5^{\circ}$ anos), mas está tranqüilo. Agora o acompanhamento está acerca da rotina, tem questões específicas, mas isso em relação a discussão de currículo. 
Caroline - O currículo não está pronto?

Secretária da Educação - Não, totalmente, não. Eu acho que nem do Brasil ainda. E a gente está construindo isso de maneira conjunta, para que não aja repetição ou aquilo que você tem que dar novamente de uma outra forma. Então os professores estão conversando sobre isso e estão fazendo junto com as equipes o que é mais importante. Porque eu pessoalmente, particularmente sou contra material apostilado. Sou contra, contra, contra e contra. Não sou só contra, sou contra, contra e contra.

Caroline - As demandas das escolas são atendidas, foram atendidas em relação ao mobiliário? Toda rede já tem mobiliário, toda rede já tem brinquedos?

Secretária da Educação - Já, no entanto a falta de alguma coisa pode ser residual ou pontual, por exemplo, acessibilidade ainda está faltando, mas isso não seria só por conta do fundamental de nove anos, é por conta da acessibilidade universal que você imagina, a gente recebeu escolas do estado que tem 50 anos, que se você ligar todos os computadores apagamse as luzes. Nesse sentido nós temos um passivo de infraestrutura muito grande, nos dois primeiros anos de 72 milhões de reais, só em infraestrutura, em adequação de sala, de espaço, telhado, muro de arrimo, uma porção de coisa, imagina são 200 escolas, temos escolas com 2000 alunos que estão na escola todos os dias. O desgaste é natural, então esta manutenção precisa ser feita

Lara - Não necessariamente vinculado ao ensino fundamental de nove anos?

Secretária da Educação - Não vinculado ao fundamental. Isso já foi feito

Lara - Quais materiais foram enviados ás escolas para que os professores tivessem contato, você falou deste livro do governo federal, com orientações do MEC, teve mais algum material específico?

Secretária da Educação - Alguns textos que foram escritos de alguns autores, os professores recebiam, mas houve muito mais a discussão da prática deles em sala de aula e foi muito rica a discussão dos professores da educação infantil e fundamental, porque sempre é muito difícil este diálogo. Eu que já estive dos dois lados sei que o que ocorre é aquela velha história, são os professores da $5^{\mathrm{a}}$ série com os da $4^{\mathrm{a}}$ série que culpam á pré-escola e assim por diante, mas ao mesmo tempo todos nós estamos na mesma rede, de todo jeito eles são produtos do nosso trabalho, não dá para culpar ninguém. Todos somos culpados ou todos estamos nos saindo muito bem. Não dá para vincular esta ou qualquer outra modalidade, mas esta integração e discussão mesmo chegaram lá para discutir, para brigar sobre concepção de educação porque a visão de educação, principalmente de quem está na educação infantil há muito anos está muito arraigada e principalmente quando você tem rede municipalizada, que era diferente em 
Santo André, lá nós criamos nossa própria rede de educação de ensino fundamental é diferente, pois ela não vem com vícios, com práticas já consolidadas. Não que elas sejam certas ou erradas, mas elas estão consolidadas já. Os professores já estavam trabalhando assim e aí vem para um rede que tem uma outra lógica, uma outra sistemática de trabalho, uma é toda enfeitada, toda colorida e, entrava em choque, mas o choque é necessário para que saíssemos fortalecidos e juntos nesta trajetória. Ainda temos problemas pontuais? Ainda temos problemas pontuais, mas eu acho que com o tempo isso vai se acomodar.

Lara - Sobre estes encontros, na escola que pesquisei havia o infantil e o fundamental, isso facilita a conversa entre os professores, mas nas escolas que não tinham como foram estes encontros?

Secretária da Educação - Visita com as crianças e depois reunião com os professores.

Lara - Então as reuniões ocorriam? Havia um tempo para isso durante a visita?

Secretária da Educação - Sim, inclusive alguns usavam o horário de HTPC das duas escolas. Em outras eles preferiram se encontrar em horários fora dos HTPCs. Já nas unidades escolares, uma turma visitando a outra e vice-versa.

Lara - Foi mais livre, então?

Secretária da Educação - É, nós não quisemos estabelecer que todos seguissem o mesmo roteiro, não adianta impor as coisas desta forma porque as pessoas funcionam e trabalham de jeitos diferentes. Então optamos por deixar que as regiões se organizassem, a gente cuidou desta organização regional e de onde para onde as crianças iam e nós fomos acompanhando o movimento, para ver assim...hum...nesta região a coisa não está andando, então lá nós vamos precisar intervir. Porque na maioria todo mundo foi se acertando, porque já misturou muito tem professor do infantil que foi para o fundamental, em outras épocas já tem a história.

Lara - Quais foram as reações dos pais?

Secretária da educação - Teve de tudo. Eram reuniões específicas por escola, porque você tinha aquele grupo de pais e que eram crianças do mesmo agrupamento, teve pais que resistira, entraram na justiça, alguns que queriam que os filhos fossem para a $3^{\text {a }}$ série e aí confundiram tudo. Enfim, mas a grande maioria entendeu, até porque era a primeira vez que eles estavam numa reunião que discutisse esta questão de como funciona o sistema de educação. Ir para as escolas sempre em reunião de pais é muito chato, ou para falar do filho para pedir ajuda e os pais pouco entendem o que é o sistema o que esperar do filho dele ao final dos oito anos, que ele seja alfabetizado e tal e essa é outra cultura que a gente está mudando. Para que serve a reunião de pais? Precisamos ajudar a formar os pais. Nesta mudança nós descobrimos um grande número de pais, grande não. Um relativo número de 
pais não alfabetizados, mães não alfabetizadas. Abrimos turmas nos mesmos horários em que as crianças estão na escola, daí ela pode frequentar, isso tem ajudado bastante. Porque a escola manda bilhete e a mãe não sabe ler e depois cobra dela na reunião de pais porque que ela não acompanhou o desenvolvimento dela, simplesmente porque ela não sabia ler. O que a escola está pedindo. Esta é uma outra cultura que a gente está implantando para que serve reunião de pais e mestres?

Lara -Qual é sua posição sobre a matrícula de crianças menores de 6 anos no ensino fundamental? Pensando na bagunça que está esta questão da nota de corte?

Secretária da Educação - Está bagunçado principalmente no Estado de São Paulo, porque eles fizeram o corte em julho, imagina, nós fazendo em março e eles em julho agora para entrar no $6^{\circ}$ ano quem vai, os nossos com o corte final que fizemos ou os deles. Quando chegar a hora, daqui dois anos chega a hora. Então, eu sou contra. Eu acho que 28 de fevereiro, enfim, primeiro dia do ano letivo é o que eu entendo que seja mais correto. Tem a maturidade, tem uma série de coisas, tem crianças, eu vou dar o exemplo da minha filha que faz aniversário em outubro, hoje ela tem 23 anos. Quando ela estava no pré eu queria que ela fizesse o prézão, na escola onde ela estudava (no Dante) chamava de prézão e a coordenadora disse que não porque ela sabia ler, ela interpretava problemas e contava histórias. Mas, daí eu disse que não era este o problema, o mecanismo de leitura dela está ótimo, mas a maturidade está zero. Ela desenha na ponta dos dedos, se ela não tiver nada para brincar ela faz teatro de fantoches. Como é que esta menina vai para a sala de uma escola extremamente tradicional e vai ficar 4 horas sentada e assim foi que até no $1^{\circ}$ ano do ensino médio ela repetiu. Uma hora isso acontece, porque uma hora a gente cansa do esforço de sempre ir atrás, porque você não tem maturidade para lidar com os conflitos. Aquela fase onde as meninas se separam dos meninos, aos 7 anos, menina de um lado e menino do outro. Um dia ela chegou em casa chorando e eu perguntei: -O que houve, porque você está chorando? E ela respondeu que era porque as meninas não queriam ser amiga dela porque ela não tinha irmão. Ela não sabia lidar com isso. Porque as outras já eram mais velhas. Então, assim, como é que eu magôo. Porque criança é cruel. Elas sabem onde pega para o outro, se é o cabelo, se é o óculos, se tem a orelha assim ou de outro jeito e quando você está mais maduro, você lida melhor com isso. E esta imaturidade interfere no processo de aprendizagem. Então eu acho que as crianças precisam ficar agrupadas mai próximas do seu nível de desenvolvimento, não é só a idade é o nível de desenvolvimento, mesmo. Por isso eu acredito no ciclo e não na série.

Lara - E agora com a obrigatoriedade da matrícula de criança aos 4 anos a partir de 2016. Você acha que vai alterar a dinâmica na organização escolar? 
Secretária da Educação - Claro. Eu sou absolutamente favorável. Eu fui lá no Congresso defender, por isso que eu sei tudo. Porque filho da classe média vai para a escola aos 3 anos de idade e porque a obrigatoriedade para os pobres é agora aos 6 anos, então nós temos que puxar mais e dar o direito ao mundo letrado, não à alfabetização, não estou puxando à escolarização. Eu estou puxando o direito à educação. E a educação se faz através do brincar, do interagir, de um monte de coisa e não necessariamente alfabetização porque muitas vezes as pessoas confundem. Ah! Agora vamos alfabetizar aos 4 anos. Não. Agora, vai ter vaga para todos na pré-escola. Este é o maior problema, porque é isso que a gente precisa, de vagas. Porque se os nossos filhos não estiverem alfabetizados até os 6 anos, a gente vai lá e briga com a professora. Mas na escola pública fala-se assim, mas ele tem 10 e a gente precisa respeitar o ritmo dele. Daqui a pouco ele tem 12, ele é um pouco mais lento, e não é isso. Aos 8 anos ele tem que estar alfabetizado. E alfabetizado é interpretar texto, é entender resolução de problemas e coisa e tal. Esta meta, nós temos perdido. As escolas estão aqui para produzir conhecimento, a função da escola é a aprendizagem dos alunos. Nós fazemos uma série de outras coisas, nós fazemos bolsa família, tem lá o Conselho Tutelar, assistência social que são importantes? São muito importantes, mas a essência da escola é produzir conhecimento. Se não a gente começa a encontrar desculpas do porque a criança não aprende. Ela não aprende porque ela é pobre, ela não aprende porque ela não come, ela não aprende porque ela apanha, ela não aprende porque ... . Tudo bem, todas estas variáveis interferem na aprendizagem, mas para isso nós vamos buscar a solução, mas enquanto isso que meios e estratégias nós vamos usar para estas crianças aprenderem. Isso é importante. Eu tinha turmas de 30 alunos, com 25 alfabetizados, 5 não. Eu tentava inúmeras estratégias, porque a incompetência estava sendo minha. A forma como eu estava alfabetizando com 25 dera certo com os outros não, cada um aprende de um jeito, muitos aprendem do mesmo jeito, outros precisam de outras estratégias. O que a gente não pode é culpabilizar a vulnerabilidade social pela baixa aprendizagem destas crianças. Isso nunca! Pobreza não é sinônimo de que a gente não aprende.

Lara - Como será este atendimento aqui em SBC, já está universalizado o atendimento da educação infantil?

Secretária da Educação - Não. Ainda de 4 e 5 anos, não. Ainda temos 12 mil crianças entre 3 anos e seis meses e 5 anos e nós temos até o fim desta gestão a criação de 16 mil novas vagas. Para isso estamos construindo o CEU, por conta de espaço físico, literalmente, SBC tem mais de $50 \%$ do seu território em área de manancial, espaço que não pode construir, mas mora gente. Então tivemos que verticalizar e a maioria das nossas escolas são muito verticalizadas. Ali está a planta do CEU que depois vocês podem ver, são dois CEUs, nós verticalizamos e a 
creche também. Porque eu preciso atender num dos nossos CEUs que é dentro do clube da Volks, vai chamar CEU São Pedro, porque é uma das regiões mais pobres de SBC, o lugar tem quatro CEUS num único espaço. Só num quarteirão nós vamos ter em média 10 mil alunos, da creche ao $5^{\circ}$ ano. Porque? Porque a cidade não tem espaço. Você tratar isso numa aula de didática, pedagogicamente o pessoal quer me matar. Eu entendo isso, mas eu entendo que criança precisa ir para a escola. Eu não vou ficar aqui lutando com o promotor do meio ambiente. Eu tenho certeza que ele jamais vai autorizar construir escola em área de manancial, então eu vou verticalizar. E vou fazer desta verticalização algo lúdico. Nas nossas escolas você vai poder subir de um andar para o outro, não por uma escada normal, você vai ter um buraco assim, cai no teto, nas escadinhas que as crianças podem subir. Vou fazer disso uma coisa lúdica, espaços diferentes, mais coloridos, mas comuns às crianças juntas.Mas com uma equipe mais organizada na lógica dos CEUs.

Lara - Você acha que as crianças estão mais felizes nas escolas de educação infantil ou de ensino fundamental?

Secretária da Educação - Olha, pelo retorno da equipe tem lugares que as crianças estão infelizes em qualquer lugar, porque escola não proporciona a elas o que elas precisam. Então eu não faria esta classificação. Eu acredito que o diretor tem um papel fundamental na aprendizagem, na motivação de seus professores e, consequentemente no aprendizado das crianças. Tem crianças que estão muito felizes por estarem nas salas de fundamental das escolas mais antigas, porque foram criadas dinâmicas de trabalho muito lúdicas. EM compensação tem outras que estão na pré-escola onde o ritmo continua o mesmo. Você não vê aquela dinâmica, aquela alegria. Por isso a gente está trabalhando muito neste currículo.

Lara - Você disse que não acredita que as crianças devam ser alfabetizadas, mas que é a favor do letramento. E você acredita que as crianças até os 8 anos tem condições de serem alfabetizadas?

Secretária da Educação - Não é só possível. Não há nenhum problema pedagógico ou psicológico. A classe média é alfabetizada, porque os pobres não podem? Porque as crianças das classes mais vulneráveis não podem, elas ...tem outro ritmo? Não. Elas tem outro cérebro? Não. Nós só viemos de contextos diferentes. È obvio que crianças que vem de contextos mais letrados terão mais facilidades, porque elas têm mais acesso. Mas que aos 8 anos há condições sim da criança estar plenamente alfabetizada, nisso eu acredito. E é isso que a gente percebe aqui, e isso o uso de instrumentos como provinha Brasil onde a gente vai identificar e ver quais são os alunos que a gente vai precisar realizar um trabalho mais intensivo. Por exemplo, não é um programa de recuperação,mas um programa de acompanhamento no horário 
contrário ao da aula. Para aqueles que tem uma dificuldade muito maior. Para aqueles que estão só se adequando, nem tanto, mas para aqueles que tem uma dificuldade maior tanto em matemática quanto em português e ciências, no horário contrário a gente tem o trabalho que se chama sala de apoio.

Lara - Com relação ás metas da prova Brasil, enfim, você não acha que os professores se ocupam muito das metas e acabam deixando de lado esta questão do brincar pelo fato de serem cobrados posteriormente por isso?

Secretária da Educação - Acho que sim. E acho muito mais que isso. As pesquisas têm monstrado que as crianças e professores tem se dedicado muito mais nos anos iniciais, depois além da criança não continuar atendendo na aprendizagem ela estaciona e começa a declinar ela começa a esquecer o que ela aprendeu, ela começa ter dificuldades na multiplicação porque ela esqueceu a adição. Ela começa a apresentar problemas na leitura por conta de problemas com encontros consonantais, ou dígrafos ou alguma coisa deste tipo. E o brincar, se a gente não cuidar, fica para hora do recreio e da merenda e acabou. E aqui a gente tem um lema: A criança tem o direito de brincar na escola. A criança tem o direito de brincar ou de fazer o que ela quiser. Fazer o que ela quiser assim, posso sair da sala? Não, mas na hora do recreio ela pode querer ficar sentada e não fazer nada, ela quer ficar quieta, quer pensar na vida. Isso não é problema. O problema é que todos os dias ela queira fazer isso. Eventualmente, ela quer só descansar. O ócio, sabe aquele momento em que ela quer imaginar que a nuvem tem jeito de camelo, ou outra que parece um cachorro. Nisso não há problema, as crianças precisam ter este tempo. Não é ficar preenchendo o tempo dela todinho, sobrecarrega a gente

Lara - Você acha que é positivo acelerar o processo de letramento?

Secretária da Educação - Sim, sem problemas.

Lara - Você acha que na sua rede o Conselho de Escola tem um papel definido dentro da escola?

Secretária da Educação - Aqui nós temos APMs e Conselhos de Escola, tem escolas que já tem os dois e tem escolas que ainda estão formando os Conselhos. A nossa intenção é migrar tudo para Conselho de Escola, porque este nome APM veio junto com a municipalização. APM é um conceito do Estado a maioria das redes municipais tem Conselho de Escola. Lara - E eles discutiram o ensino fundamental, as escolas que já tinham Conselho de Escola? Secretária da Educação - Somente aquelas que iam receber as crianças, o Conselho de Escola além de ser informado, foi feita toda a explicação jurídica o porquê disso. Até no ministério 
público eu tive que ir para explicar porque que São Bernardo estava mudando só agora, porque que ia fazer de um ano para o outro. Nós tivemos que dar várias explicações.

Caroline - Mas, o Conselho de Escola foi protagonista nas decisões? Qual foi o papel do Conselho de Escola neste momento?

Secretária da Educação - O que eles queriam entender era o processo, muito mais de informação. Eles queriam entender o processo do fundamental de 9 anos, porqque SBC estava atrasado e como seria este processo. Mas não houve uma atuação deles, até porque não caberia. Do Conselho Municipal de Educação sim, mas dos Conselhos de Escola não.

Lara - Mais ou menos quantas escolas da rede socilitaram algum recurso complementar?

Secretária da Educação - 69, em torno de 69 escolas que são do Ensino Fundamental solicitaram recursos como carteiras, brinquedos, mais isso. Porque o restante de infraestrutura fizemos para a rede toda. Ao todo são 69 na rede toda. Todas pediram.

Lara - E você se tivesse que escolher deixaria as crianças na educação infantil ou ia preferir deixá-las nas escolas de ensino fundamental?

Secretária da Educação - Em algumas eu deixaria na educação infantil outras iriam para o fundamental isso tem muita relação de como é a escola, com a direção da escola, com a dinâmica da escola. Enquanto rede não, tanto é que em Santo André nós tínhamos as duas num mesmo espaço físico, isso nós estamos tentando fazer aqui, as novas construções todas são integradas com creche, pré-escola e fundamental. Chega dessa divisão, nós não podemos ser um bando nós precisamos ter uma rede e a rede pressupõe que eu conheça e saiba quem são as crianças desde pequenas. Quando você vê os CEUs que vão ter da creche até EJA, você vê uma integração muito maior e aí a interação das crianças maiores com as crianças menores é muito bacana. Essa coisa do tomar conta, do brincar junto, do querer ensinar, isso ajuda muito. Aquela velha história, às vezes o professor explica e o aluno não entendeu, o colega do lado fala duas palavras diferentes ele consegue entender o mecanismo. Um pouco isso.

Lara - Houve alguma recomendação aqui da secretaria para que o número de alunos fosse menor nas salas de primeiro ano?

Secretária da Educação - Não, a recomendação é geral para diminuir o número de alunos em todas as unidades. Aqui tem uma legislação que quando você tem um aluno especial, com alguma deficiência diminuem 5 alunos normais. Mas o que estamos trabalhando, nossa meta é que tenhamos 25 alunos por sala até o final da gestão. Vamos conseguir em boa parte das escolas, infelizmente não todas. Mas também o nosso número nunca passa de 30. Eventualmente você tem um caso ou dois, por conta de uma decisão judicial. Mas estamos batalhando para o fundamental ter 25 . 
Lara - Então no Infantil 4, Infantil 5 a média é?

Secretária da Educação - 22

Lara - Isso segue a legislação?

Secretária da Educação - Não. Isso é organização da rede. E onde nós temos problemas? Nas regiões mais pobres onde a gente vai construir os CEUS. Aí nós resolvemos, abaixando para 20 ou 22.

Lara - Existe algum projeto experimental para essas séries iniciais?

Secretária da Educação - Não. Estamos fazendo um controle de acompanhamento de todos os alunos, mais especificamente deste primeiro grupo de alunos que foi para o ensino fundamental de 9 anos e a ideia é de acompanhá-los até o final do fundamental, no $9^{\circ}$ ano. Fazer um acordo com o Estado, não é um grupo de controle, mas é saber como estas crianças estão se saindo.

Lara - Sobre as séries e anos seguintes você disse que serão mais interessantes por conta da entrada mais cedo na escola, pensando no currículo que não tem ainda nada fechado conta um pouquinho mais sobre isso para nós?

Secretária da Educação - Não, em São Bernardo já tem. Não para esta nova reformulação.

Caroline - Você pode adiantar para gente o que você está pensando?

Secretária da Educação - Não posso porque a discussão maior é o direito de brincar e a alfabetização de forma lúdica. Começando com o letramento, mas indo na direção daquelas crianças que já tem condição, maturidade, etc. Sempre respeitando o ciclo, mas sabendo que ao final deste primeiro ciclo ela esteja alfabetizada. Sem concessão, ao final ela tem que estar alfabetizada, a não ser que ela tenha um problema sério, grave. E quando eu digo que não tem concessão é assim não há a discussão, ele não aprende. Então precisa fazer diagnóstico, ele tem dislexia, disgrafia ou qualquer coisa nós encaminhamos para diagnóstico e sabendo que ele não tem nada, ele só não está acompanhando a forma como o professor está trabalhando com ele. Daí vamos pensar como é que vamos acompanhar este aluno e quais os recursos que vamos utilizar com ele para que ele possa aprender. Vamos pensar em tudo que possa lhe causar dificuldade física, mas longe disso ao final do ciclo ele deve estar alfabetizado.

Lara - Minhas perguntas acabaram, mas você gostaria de falar mais alguma coisa que eu não tenha perguntado?

Secretária da Educação - Bom, eu sou favorável à emenda 59 da obrigatoriedade, sou à favor da não obrigatoriedade da creche se a mãe pode ficar é importante que a mãe fique e acima de tudo a creche é um direito da criança e não da mãe trabalhadora. A mãe trabalhadora tem que ter o espaço, mas se fosse assim as empresas é quem teriam de prover, para nós na educação 
pública o direito é da criança. A escola é para a criança por isso que eu, pessoalmente sou contra as creches noturnas, porque aí não é creche é assistência. Isso não é educação. 
APÊNDICE D - Desenhos das crianças entrevistadas sobre a escola

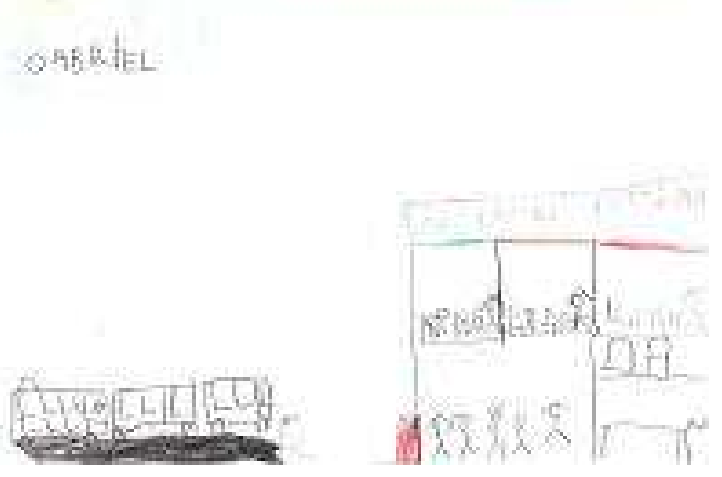

Desenho 1

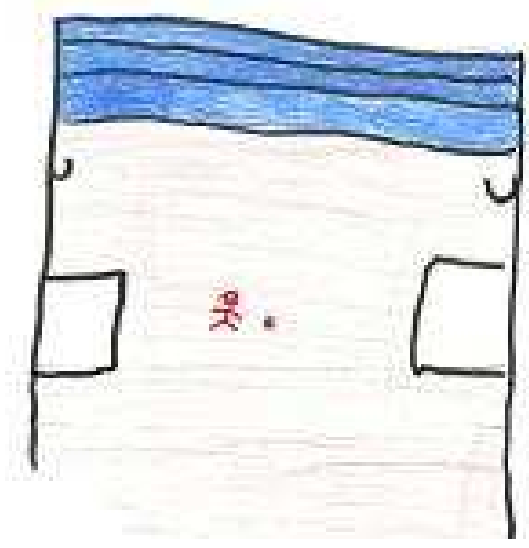

Desenho 3

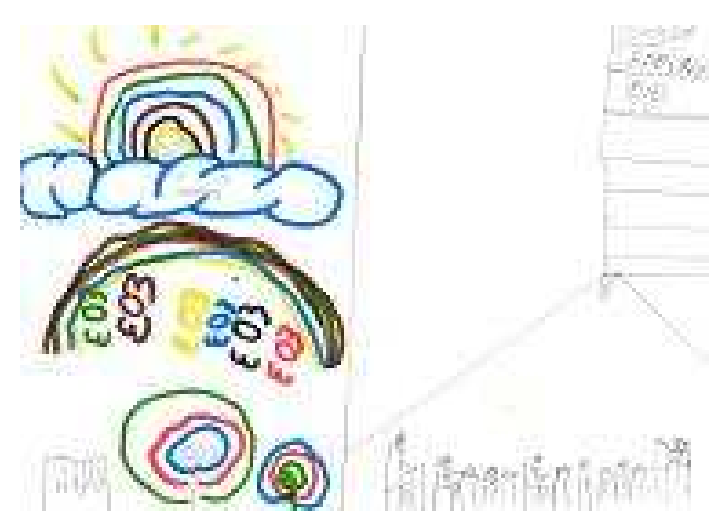

Desenho 2

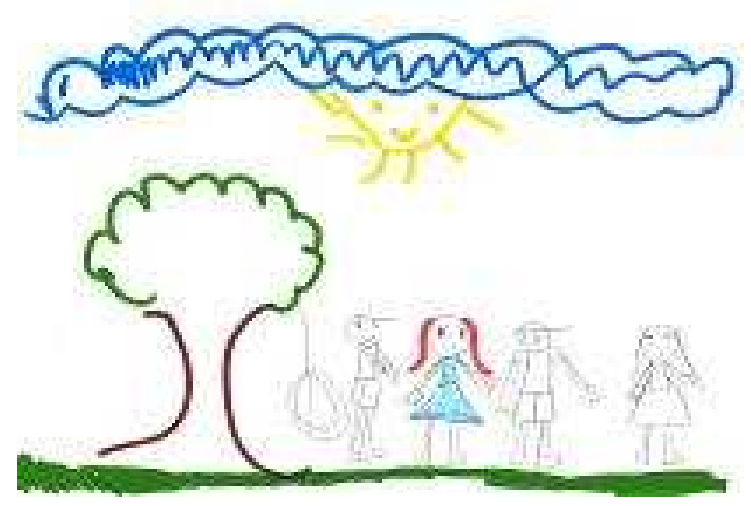

Desenho 4

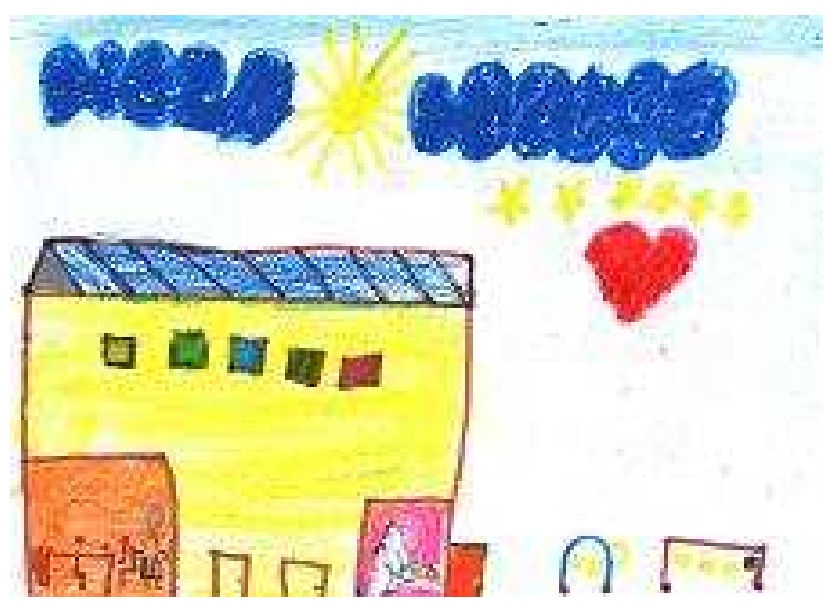

Desenho 5

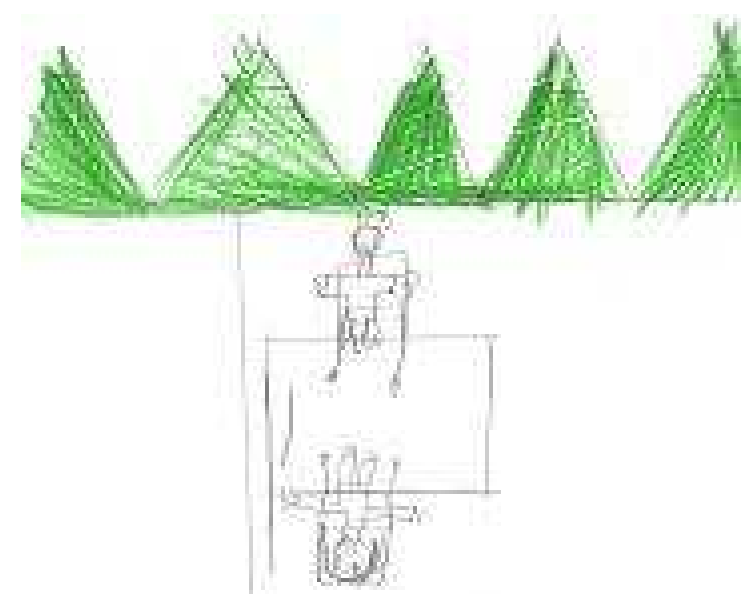

Desenho 6 
ANEXOS 


\section{ANEXO A - Objetivos e conteúdos dos componentes curriculares do $1^{\circ}$ ano do Ensino Fundamental da escola pesquisada}

AREAS DE CONHECIMENTO - ENSINO FUNDAMENTAL

PRIMEIRO ANO DO ENSINO FUNDAMENTAL DE NOVE ANOS

\begin{tabular}{|c|c|}
\hline OB.JETIVOS & CONTEÚDOS \\
\hline $\begin{array}{l}\text { Ampliar gradativamente suas } \\
\text { possibilidades de comunicação e } \\
\text { expressäo, interessando-se por conhecer } \\
\text { vários gencros orais e escritos; } \\
\text { Familiarizar-se com a escrita por meio do } \\
\text { manuseio de livros, revistas e outros } \\
\text { portadores de texto; } \\
\text { Escutar textos lidos, apreciando a leitura } \\
\text { feita pelo professor e outros; } \\
\text { Estabilizar a escrita do nome próprio com } \\
\text { total autonomia; } \\
\text { Reconhecer o nome dos amigos da classe; } \\
\text { Relacionar o falado ao escrito à partir dos } \\
\text { textos já memorizados e localizar palavras } \\
\text { no texto; } \\
\text { Avançar na hipótese de escrita; } \\
\text { Relatar fatos do cotidiano; } \\
\text { Formalizar oralmente } \\
\text { específicas; instruçóes } \\
\text { Reescrever textos de memória de acordo } \\
\text { com sua hipótese de escrita; } \\
\text { Compreender que as letras são simbolos } \\
\text { utilizados para representar a escrita; } \\
\text { Reconhecer as letras do alfabeto; } \\
\text { Compreender a imagem e a palavra como } \\
\text { formas de representaçáo, como linguagens } \\
\text { criadas pelo homem para atender a } \\
\text { necessidade de registrar histórias, ideias e } \\
\text { sentimentos, de se comunicar e de } \\
\text { interagir com o outro; } \\
\text { Representar a compreensáo do texto por } \\
\text { meio de desenho. }\end{array}$ & 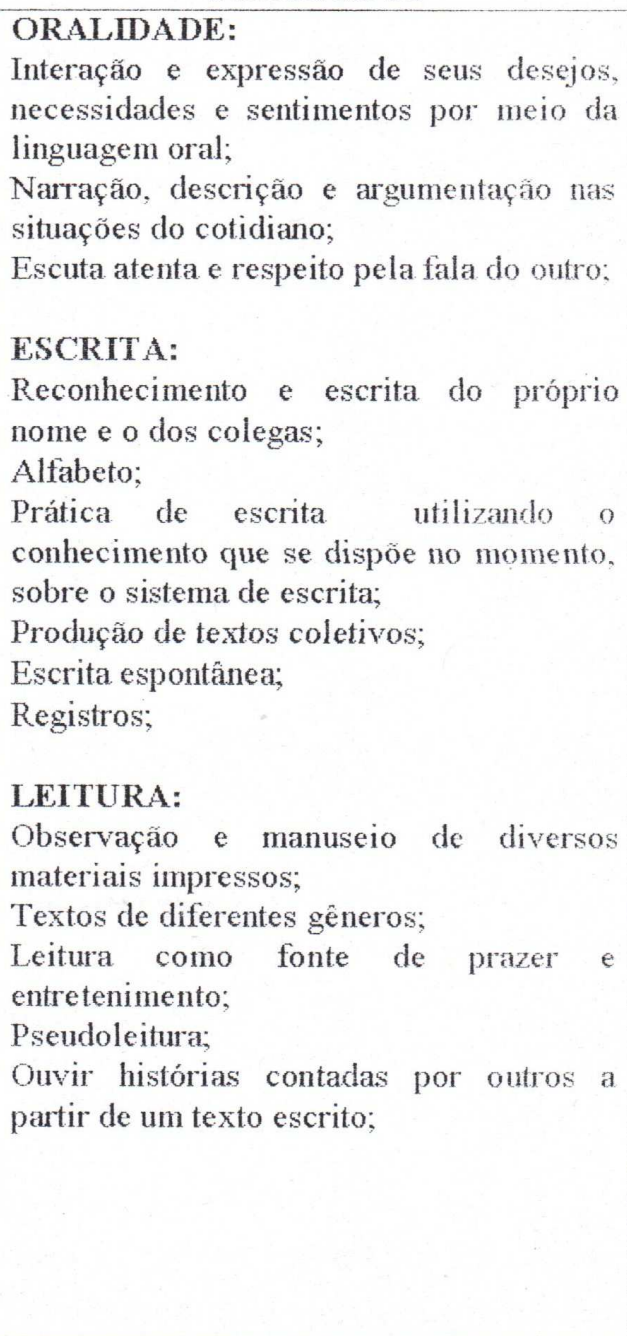 \\
\hline
\end{tabular}


PRIMEIRO ANO - FUND AMENTAL DE NOVE ANOS

OB.IETIVOS - MATEMÁTICA

\begin{tabular}{|c|c|}
\hline OBJETIVOS & CONTEÚDOS \\
\hline 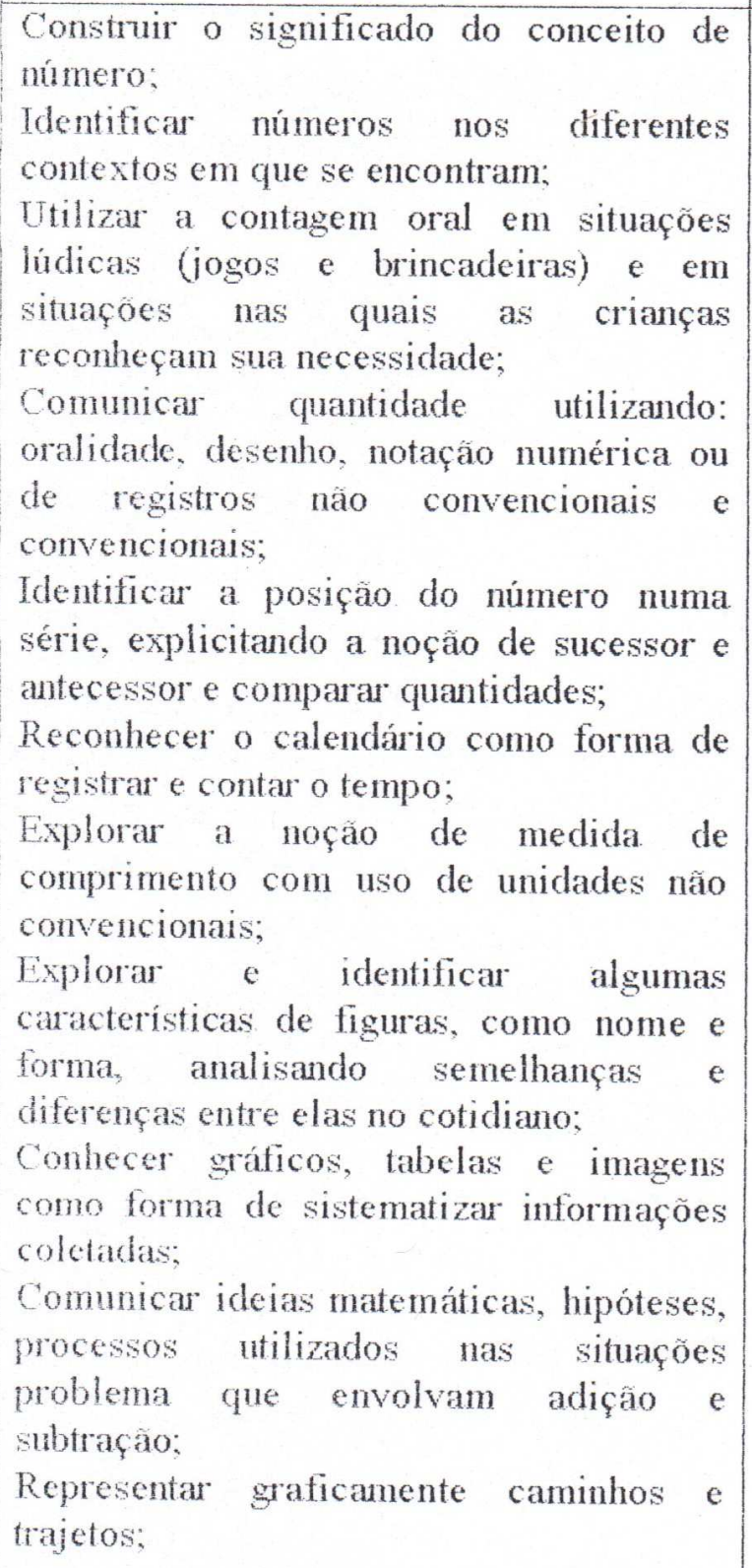 & $\begin{array}{l}\text { NUMEROS E SISTEMA DE } \\
\text { NUMERAÇÃO: } \\
\text { Portadores numéricos; } \\
\text { Quantificação; } \\
\text { Contagem; } \\
\text { Sobrecontagem; } \\
\text { Classificação; } \\
\text { Seriação; } \\
\text { Agrupamento; } \\
\text { Conceito de número; } \\
\text { Registros; } \\
\text { Adiçâo; } \\
\text { Subtração; } \\
\text { Situaçôes-problema } \\
\text { Jogos } \\
\text { Brincadeiras; } \\
\text { GRANDEZA E MEDIDAS: } \\
\text { Tempo; } \\
\text { Comprimento; } \\
\text { Peso; } \\
\text { ESPAÇO E FORMA: } \\
\text { Formas geométricas e suas caracteristicas; } \\
\text { Trajetos; } \\
\text { Percursos; } \\
\text { Espaço físico; } \\
\text { TRATAMENTO DA INFORMACAO: } \\
\text { Informaçôes matemáticas contidas em } \\
\text { imagens, tabelas e gráficos; } \\
\text { Coleta de dados e informaçoes para } \\
\text { elaboraçấo coletiva de formas para } \\
\text { organiza-los e comunica-los; }\end{array}$ \\
\hline
\end{tabular}




\section{OB.JETIVOS E CONTEÚDOS - FUNDAMENTAL DE NOVE ANOS CIENCIAS}

\begin{tabular}{|c|c|}
\hline OB.JETIVOS & CONTEUDOOS \\
\hline $\begin{array}{l}\text { Compreender a importância da } \\
\text { alimentaçào saudável e açoes de higiene } \\
\text { que contribuem para saúde; } \\
\text { Identificar as partes do corpo humano; } \\
\text { Conhecer as funçoes dos órgaos do } \\
\text { sentido; } \\
\text { Estabelecer relaçoes entre as } \\
\text { características e o comportamento dos } \\
\text { animais com as condiçoes do ambiente em } \\
\text { que vivem; } \\
\text { Demonstrar interesse e curiosidade pelo } \\
\text { meio ambiente em que vive. Bem como, } \\
\text { adquirir atitudes de respeito e } \\
\text { preservaçaro; }\end{array}$ & $\begin{array}{l}\text { Corpo humano; } \\
\text { Órgãos do sentido; } \\
\text { Higiene; } \\
\text { Animais;-3: } \\
\text { Agua; } 4 \text { " } \\
\text { Lixo; } 4 \text { Plantas; }\end{array}$ \\
\hline
\end{tabular}

\section{HIS TORIA E GEOGRAFIA}

Conhecer a diversidade cultural presente em sua comunidade;

Valorizar a oralidade como transmissâo de - conhecimento;

Interessar-se e demonstrar curiosidade pelo mundo social e natural, formulando perguntas, imaginando soluçoes para compreendè-lo;

Conhecer algumas características das culturas indigena e africana;

Observar e comparar os componentes da paisagem e as transformaçôes realizadas pelo homem:

Estabelecer algumas relaçoes entre os seres humanos e natureza, valorizaçâo e preservaçao das espécies e qualidade de vida do planeta;

Adquirir atitudes de valorizaçáo do meio ambiente; 


\section{ENSINO FUNDAMENTAL DE NOVE ANOS - PRIMEIRO ANO OBJETIVOS E CONTEÚDOS - ARTE}

\begin{tabular}{|c|c|}
\hline OBJETIVOS & CONTEÚDOS \\
\hline $\begin{array}{l}\text { Utilizar diversos materiais sobre } \\
\text { diferentes superfícies para ampliar suas } \\
\text { possibilidades de expressão e } \\
\text { comunicação; } \\
\text { Produzir trabalhos de arte utilizando a } \\
\text { linguagem do desenho, da pintura, da } \\
\text { modelagem, da colagem e da construção, } \\
\text { preocupando-se com a organização do } \\
\text { espaço físico e respeitando as produções } \\
\text { individuais ou coletivas; } \\
\text { Comunicar, apreciar, e expressar-se por } \\
\text { meio da música valorizando a mesma } \\
\text { como produto cultural; } \\
\text { Criar e representar por meio de histórias } \\
\text { conhecidas (dramatização); }\end{array}$ & $\begin{array}{l}\text { Exploração de diversos materiais; } \\
\text { Criação de desenhos, pinturas, esculturas, } \\
\text { construções, colagens, etc.; } \\
\text { Brincadeiras, jogos, danças e atividades } \\
\text { diversas de movimento articulando-os } \\
\text { com a linguagem musical; } \\
\text { Pesquisas; }\end{array}$ \\
\hline \multicolumn{2}{|c|}{ EDUCAÇÃO FÍSICA } \\
\hline OBJETIVOS & CONTEÚDOS \\
\hline $\begin{array}{l}\text { Ampliar as possibilidades do próprio } \\
\text { movimento utilizando gestos diversos e o } \\
\text { ritmo corporal nas suas brincadeiras: } \\
\text { danças, jogos e demais situações de } \\
\text { interação; } \\
\text { Superar os conflitos desencadeados nas } \\
\text { brincadeiras; } \\
\text { Compreender a importância das regras nas } \\
\text { diferentes propostas de jogos; } \\
\text { Nomear e conhecer as características e } \\
\text { funções de cada parte do corpo nas } \\
\text { atividades desenvolvidas; } \\
\text { Participar de danças simples ou adaptadas, } \\
\text { pertencentes às manifestações culturais } \\
\text { (folclóricas) ou de outro tipo que estejam } \\
\text { presentes no cotidiano; } \\
\text { Aprender a utilizar os movimentos básicos } \\
\text { ao explorar com confiança e autonomia, } \\
\text { podendo manipular e explorar objetos de } \\
\text { diferentes características; }\end{array}$ & $\begin{array}{l}\text { Funções das partes do corpo durante os } \\
\text { movimentos; } \\
\text { Dança; } \\
\text { Equilibrio; } \\
\text { Organização espacial; } \\
\text { Jogos; } \\
\text { Danças folclóricas; } \\
\text { Conceitos de lateralidade; } \\
\text { Movimentos combinados. }\end{array}$ \\
\hline
\end{tabular}


ANEXO B - Ficha de rendimento escolar do aluno regularmente matriculado no Ensino Fundamental da escola pesquisada

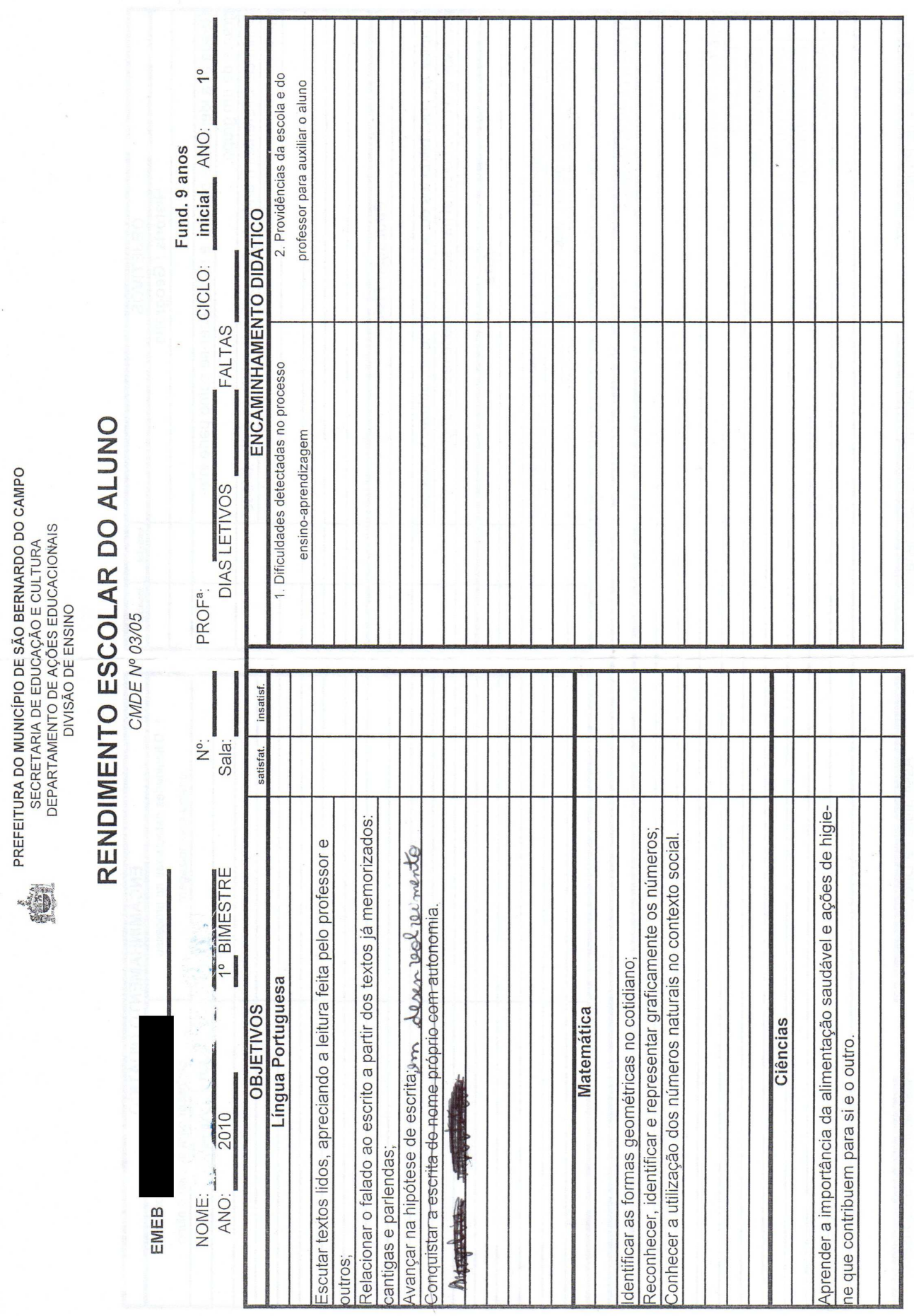




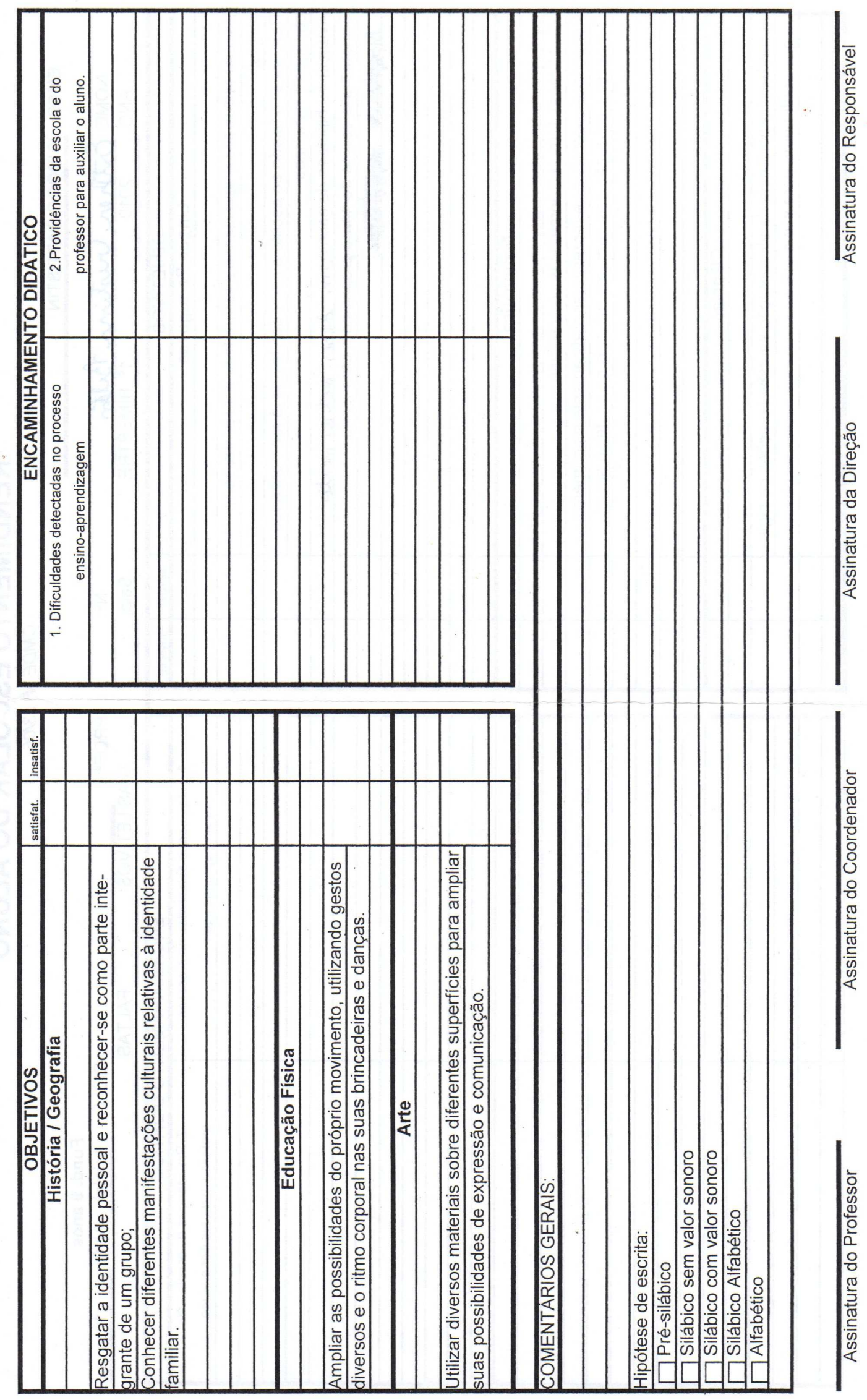

